UNIVERSIDADE DE SÃO PAULO

INSTITUTO DE GEOCIÊNCIAS

\title{
GEOQUÍMICA E GEOCRONOLOGIA DO PLUTONISMO DE ARCO MESO-CENOZOICO NA CORDILHEIRA CENTRAL DA COLÔMBIA E OS PROCESSOS DE ACRESÇÃO CRUSTAL NOS ANDES DO NORTE
}

\section{Camilo Bustamante Londoño}

Orientador: Prof. Dr. Carlos José Archanjo

TESE DE DOUTORAMENTO

Programa de Pós-Graduação em Mineralogia e Petrologia

SÃO PAULO

2016 
UNIVERSIDADE DE SÃO PAULO

INSTITUTO DE GEOCIÊNCIAS

\section{GEOQUÍMICA E GEOCRONOLOGIA DO PLUTONISMO DE ARCO MESO-CENOZOICO NA CORDILHEIRA CENTRAL DA COLÔMBIA E OS PROCESSOS DE ACRESÇÃO CRUSTAL NOS ANDES DO NORTE}

\section{Camilo Bustamante Londoño}

Orientador: Prof. Dr. Carlos José Archanjo

TESE DE DOUTORAMENTO

Programa de Pós-Graduação em Mineralogia e Petrologia

SÃO PAULO

2016 
Autorizo a reprodução e divulgação total ou parcial deste trabalho, por qualquer meio convencional ou eletrônico, para fins de estudo e pesquisa, desde que citada a fonte.

Ficha catalográfica preparada pelo Serviço de Biblioteca e Documentação do Instituto de Geociências da Universidade de São Paulo

Bustamante Londoño, Camilo

Geoquímica e geocronologia do plutonismo de arco meso-cenozoico na Cordilheira Central da Colômbia e os processos de acresção crustal nos Andes do Norte / Camilo Bustamante Londoño. - São Paulo, 2016. 184 p. + anexos

Tese (Doutorado) : IGc/USP

Orient.: Archanjo, Carlos José

1. Rochas graníticas 2. Geoquímica 3. Geocronologia I. Título 
in memoriam

Fernando, Bernardo e Marta 


\section{AGRADECIMENTOS}

Agradeço ao Instituto de Geociências da Universidade de São Paulo pela oportunidade que me deu para o desenvolvimento de um projeto de doutorado nos Andes do Norte, e com isso contribuir ao conhecimento de uma das áreas mais complexas e desconhecidas da cadeia Andina. Este projeto não poderia ter sido realizado sem o apoio da Fundação de Amparo a Pesquisa do Estado de São Paulo (FAPESP; proc. 2010/19068-6), da Fundación para la Promoción de la Ciencia y la Investigación del Banco de la República de Colombia (Proyecto 3171) e do Fondo Corrigan-ACGGP-ARES, a quem agradeço imensamente.

Ao Prof. Dr. Carlos José Archanjo que aceitou o desafio de me orientar na modalidade de doutorado direto, agradeço a confiança e liberdade que me deu para encaminhar a minha pesquisa, bem como sua disposição para aprender sobre a geologia Colombiana e discutir, sem preconceitos científicos, os diversos temas da tectônica dos Andes do Norte. Sua orientação foi fundamental para entender a importância de publicar os resultados de uma pesquisa científica.

Ao Prof. Dr. Agustín Cardona Molina que me encaminhou na pesquisa cientifica desde que orientou meu trabalho de formatura na Universidade EAFIT. Ele é o responsável pela estruturação inicial do atual projeto de doutorado e a motivação para enfrentar este estágio da minha vida acadêmica. Suas constantes discussões foram fundamentais para esclarecer diversos aspectos da complexa tectônica Andina

Ao Dr. Victor Valencia que foi o responsável pela qualidade dos dados analíticos disponíveis nessa tese. Agradeço o tempo que ele dedicou para que eu pudesse fazer com segurança as análises em zircão, bem como as interessantes discussões sobre a interpretação dos resultados.

Ao Prof. Dr. Jeff Vervoort que me abriu a portas do GeoAnalytical Lab da Washington State University. Deixo o meu reconhecimento a ele e sua equipe, Diane Wilford, Charles Knaak e Chris Fisher, que facilitaram a aquisição de dados isotópicos de $\mathrm{Sr}, \mathrm{Nd}, \mathrm{Pb}$ e $\mathrm{Hf}$ de qualidade. A ajuda e assessoria do Dr. Rick Conrey e a Dra. Laureen Wagoner foi ainda muito importante na confecção do banco de dados geoquímicos disponíveis nessa tese. O estágio na Washington State University, financiado pelo programa BEPE da FAPESP (proc. 2012/14396-0), foi um período decisivo tanto na consolidação dos dados analíticos como no amadurecimento de minha formação acadêmica.

Ao Prof. Dr. Antonio García Casco, que conheci no final da minha graduação na Colômbia, e com quem depois tive interessantes discussões em São Paulo sobre petrologia e 
tectônica, iluminou o meu trabalho no momento no qual eu precisava de ideias alternativas para encaminhar as interpretações tectônicas.

Ao Prof. Dr. Andres Bustamante Londoño pelo apoio que foi de fundamental importância durante tudo o período na pós-graduação. A ele agradeço a orientação em todos os aspectos, notadamente em como viver na cidade de São Paulo e sobre a vida universitária na USP. Além disso, sou reconhecido pelas discussões e esclarecimentos relacionados ao metamorfismo da Cordilheira Central da Colômbia.

Interessantes e frutíferas discussões sobre diferentes aspectos da vida pessoal e acadêmica foram mantidas constantemente com os meus colegas da pós-graduação, os quais sem dúvida contribuíram para minha formação pessoal e profissional. Por isso quero agradecer a Giovanna de Souza Pereira, Luiz Gustavo Viegas, Diego Gómez, María Isabel Giraldo, Santiago León e Astrid Siachoque. Ao geólogo Mario Lara agradeço sua disposição e apoio nas etapas de campo nas bonitas regiões de Caldas e Tolima. Aos colegas da minha sala Alice, Cláudio, Cassandra, Aniceto e Letícia, agradeço o respeito e companheirismo que propiciou um ambiente tranquilo para estudar.

Quero reconhecer o apoio do pessoal técnico e administrativo do Instituo de Geociências da USP durante o período de pós-graduação, em particular o Vasco, Angélica, Paulo, Luiz, Henrique, Katherine, Magali e Leonardo.

Aos meus sobrinhos brasileiros Emilio e Rebeca pela sua inspiradora a agradável presença no começo da minha estada em São Paulo.

Aos meus pais Emilio e Judith por seu infinito apoio, fortaleza e exemplo.

A minha esposa Sofía que me acompanhou desde o começo desta jornada e sempre me alentou a continuar. 


\section{RESUMO}

Os Andes do Norte evoluíram a partir dos episódios sucessivos de subducção e colisão de terrenos após a separação de Pangea no Triássico Inferior. Em contraste com a parte central e sul dos Andes, a margem continental do Equador, Colômbia e Venezuela registram a infuência do plateau do Caribe que colidiu com a placa Sul Americana no Cretáceo Superior. Nosso estudo concentra-se nas rochas magmáticas do Jurássico e Paleógeno hospedadas em sua maioria na Cordilheira Central da Colômbia. Os modelos tectônicos tradicionais tem definido um embassamento Permo-Triássico para a Cordilheira Central, também conhecido como Terreno Tahamí, enquanto rochas mais antigas de idade Paleozoica e núcleos restritos Grenvillianos (ca. $1 \mathrm{Ga}$ ) ocorrem na Cordilheira Oriental, sendo reunidos no Terreno Chibcha. A falha Otú-Pericos limitaria os terrenos Tahamí e Chibcha. Contudo, os resultados aqui obtidos indicam que: (i) as rochas Permo-Triássicas intrudidas por batólitos Jurássicos mostram composições similares nos dois lados da falha, e (ii) sequências metassedimentares Jurássicas, até então desconhecidas na Cordilheira Central, ocorrem intercaladas com o embassamento metamórfico. Estes resultados mostram que a falha Otú-Pericos não deve representar um limite de terrenos tectonoestratigráficos, e que a distribuição espacial das sequências Permo-Triássicas na Cordilheira Central tem sido superestimada. Além disso, idades U-Pb associadas a composições de Lu-Hf dos zircões detríticos sugere uma origem para-autóctone para rochas permo-triássicas. Um volumoso magmatismo que se estende do Jurássico ao Cretáceo intrude o embasamento do flanco oriental da Cordilheira Central. Embora sua colocação num arco magmático continental seja incontestável, a gênese desses magmas ainda é debatida. Nossos resultados indicam que o magmatismo Jurássico evoluiu num arco estacionário ativo em torno de $200 \mathrm{Ma}$. O volume de magma diminuiu em ca. 165 Ma para cessar em 130 Ma. Além disso, dados geoquímicos e isotópicos indicam que esses magmas foram diferenciados em níveis crustais rasos e tornaram-se mais juvenis nos pulsos magmáticos finais. Isto implica que a fonte do magma mudou no ambiente de subducção, provavelmente em resposta à diminuição do aporte de sedimentos na cunha mantélica associado a um regime tectônico onde a convergência foi francamente oblíqua. $\mathrm{O}$ magmatismo reiniciou em ca. 90 Ma com a subducção da placa do Caribe sob a margem NW da placa Sul-Americana, o que ocasionou a acreção de vários fragmentos oceânicos e, consequentemente, espessamento da margem continental. Uma fonte profunda dos plútons do Cretáceo Superior e Eoceno aparentemente está registrada na elevada razão $\mathrm{Sr} / \mathrm{Y}$ desses magmas, que se formariam e seriam diferenciados em alta pressão onde granada é estável. Zircoes detríticos eocênicos são encontrados nas bacias sedimentares do leste da Colômbia, os 
quais relacionamos à fontes ígneas distais e/ou mais proximais, provavelmente localizadas na Cordilheira Central conforme indicam as composições isotópicas de Hf nos zircões. Alguns batólitos eocênicos, como o tonalito de Santa Marta, estão alojados perto da sutura que reune os complexos de acresção de origem oceânica à margem continental pré-cretácica da Sierra Nevada de Santa Marta. Estudos da trama magnética do tonalito de Santa Marta indicam que sua colocação explorou estruturas extensionais formadas numa zona de cisalhamento destral formada pelo deslocamento da placa do Caribe no Eoceno. O magmatismo continental do segmento dos Andes do Norte terminou no Eoceno Meio, provavelmente pela dificuldade em subductar a espessa litosfera do plateau do Caribe. 


\begin{abstract}
The Northern Andean mountain belt, which includes the western margin of Ecuador,
\end{abstract} Colombia and Venezuela evolved by successive episodes of subduction and terrane collision after the break-up of Pangea in the Lower Triassic. In contrast with the Central and Southern Andean Cordillera, the northern chain records the influence of the Caribbean plateau that collided with the South American plate in the Late Cretaceous. Our study focuses on the Jurassic and Paleogene magmatic rocks hosted mostly in the Central Cordillera of Colombia. The traditional tectonic models have been defining a Permo-Triassic basement for the Central Cordillera, named Tahamí Terrane, and Paleozoic sequences including vestiges of the Grenville orogeny (ca. $1 \mathrm{Ga}$ ) hosted in the Eastern Cordillera and grouped in the Chibcha Terrane. The Otú-Pericos fault has been considered as the limit between both terranes. Nevertheless, the results obtained here indicate that: $(i)$ the Permo-Triassic rocks intruded by Jurassic batholiths show similar compositions on both sides of the fault, and (ii) until now unnoticed Jurassic metasedimentary sequences occur interleaved with the Permo-Triassic metamorphic basement. These findings imply that the Otú-Pericos fault is not a limit of tectonostratigraphic terranes and that the spatial distribution of the Permo-Triassic sequences in the Central Cordillera has been overestimated. A para-autochthonous origin for rocks recording contrasting Permian to Jurassic histories is proposed for the units at both sides of the Otú-Pericos fault. A voluminous Late Jurassic to Early Cretaceous magmatism intrudes the basement of eastern flank of the Central Cordillera. Although their emplacement in a continental arc setting is indisputable, the magma genesis is still debated. Our results indicate that the Jurassic magmatism evolved in a stationary arc at ca. 200 Ma. The magma volumes decreased at ca. $165 \mathrm{Ma}$ to cease at ca. $130 \mathrm{Ma}$. Furthermore, geochemical and isotopic data indicates that these magmas differentiated at shallow crustal levels and became more juvenile towards the latest magmatic pulses. This implies that the magma source changed in a subduction setting probably recording the decreasing of the sedimentary input to the mantle wedge in a tectonic setting dominated by oblique convergence. The magmatism resumed at ca. 90 Ma with the subduction of the proto-Caribbean under NW South America which, in addition, accreted to the continent several oceanic fragments that thickened the continental margin. A deep source of the Late Cretaceous to Eocene plutons would be recorded in the adakite-like signature (high $\mathrm{Sr} / \mathrm{Y}$ ratios) of the magmas that would have been differentiated at a high pressure where garnet is stable. Detrital Eocene zircons are also recorded in basins from eastern Colombia, which could be related to both distal igneous sources and/or more proximal sources that according the Hf isotopic compositions would be located in the Central 
Cordillera. Some Eocene batholiths, like the Santa Marta tonalite, are emplaced close to the suture that juxtaposes the Cretaceous oceanic terranes to the continent. Fabric studies of the Santa Marta tonalite indicated that its emplacement exploited extensional structures formed in bulk dextral shear component formed by the lateral displacement of the Caribbean plate in the Eocene. The continental magmatism of the northern Andean margin stops in the Middle Eocene probably related to the difficulty of the thick Caribbean plateau to subduct. 


\section{SUMÁRIO}

Página

Capítulo 1. Introdução 1

1.1. ORGANIZAÇÃO DA TESE 1

1.2. CONTEXTO GEOLÓGICO REGIONAL 2

1.2.1. Arcabouço tectônico da Colômbia 3

1.2.2. Magmatismo Meso-Cenozóico na Cordilheira Central 7

1.3. JUSTIFICATIVA E OBJETIVOS 10

1.4. MATERIAIS E MÉTODOS 11

1.4.1. Geoquimica em rocha total 11

1.4.2. Geocronologia U-Pb LA-ICP-MS em zircão 12

$\begin{array}{ll}\text { 1.4.3. Isótopos de } \mathrm{Nd}, \mathrm{Hf}, \mathrm{Pb} \text { e } \mathrm{Sr} & 12\end{array}$

$\begin{array}{ll}\text { 1.4.4. Anisotropia de Suscetibilidade Magnética } & 14\end{array}$

Capítulo 2. U-Pb ages and $\mathrm{Hf}$ isotopes in zircons from ParaAutochthonous Mesozoic terranes in the western margin of Gondwana: implications for the terrane configurations in the Northern Andes $\quad 17$

ABSTRACT 17

2.1. INTRODUCTION

2.2. GEOLOGICAL SETTING 21

2.3. ANALITICAL METHODS 23

2.3.1. LA-ICP-MS U-Pb Geochronology in zircon 23

$\begin{array}{ll}\text { 2.3.2. Hf isotopes in zircon } & 23\end{array}$

2.4. RESULTS 24

2.4.1. Tierradentro unit 24

$\begin{array}{ll}\text { 2.4.2. Detrital zircons of the Tahamí terrane } & 27\end{array}$

2.5. Hf ISOTOPE GEOCHEMISTRY 29

2.5.1. Tierradentro unit 29

2.5.2. Graphite-quartz-muscovite schist 30

2.6. DISCUSSION 30

2.7. CONCLUSIONS 33

Capítulo 3. Late Jurassic to Early Cretaceous plutonism in the Colombian Andes: a record of long-term arc maturity

$\begin{array}{ll}\text { ABSTRACT } & 34\end{array}$

3.1. INTRODUCTION

3.2. GEOLOGICAL SETTING 37

3.2.1. Mesozoic plutonism in the southern Central Cordillera and the Upper 37 Magdalena valley

3.3. SAMPLING AND ANALYTICAL METHODS 38

3.3.1. U-Pb Geochronology in zircon 39

3.3.2. Hf isotopes in zircon $\quad 39$

3.3.3. Whole rock XRF and ICP-MS geochemistry 40

3.3.4. $\mathrm{Nd}, \mathrm{Hf}$ and $\mathrm{Pb}$ radiogenic isotopes $\quad 40$

3.4. RESULTS 41 
3.4.1. Zircon U-Pb geochronology

3.4.2. Whole-rock elemental and isotope geochemistry, and Hf isotopes in 44 zircon

3.4.2.1. Payandé stock

47

3.4.2.2. Ibagué batholith 48

3.4.2.3. Mariquita stock 49

3.5. DISCUSSION 50

3.5.1. Age distribution of the Jurassic-Early Cretaceous magmatic activity 50

3.5.2. Genesis of the Mesozoic magmatic arc of the Central Cordillera 52

3.5.3. Jurassic tectonomagmatic evolution of the Northern Andes 59

3.6. CONCLUSIONS 60

Capítulo 4. Geochemistry and isotopic signatures of Paleogene plutonic and detrital rocks of the Northern Andes of Colombia: a record of postcollisional arc magmatism

$\begin{array}{ll}\text { ABSTRACT } & 62\end{array}$

4.1. INTRODUCTION 63

4.2. GEOLOGICAL SETTING 63

4.2.1. Paleogene magmatism in the Colombian Andes 65

4.3. SAMPLING AND METHODS 66

4.3.1. Whole rock geochemistry 67

4.3.2. Whole rock $\mathrm{Sr}, \mathrm{Nd}$ and $\mathrm{Pb}$ isotopes 67

4.3.3. U-Pb Geochronology in zircon 68

$\begin{array}{ll}\text { 4.3.4. Hf isotopes in zircon } & 68\end{array}$

$\begin{array}{ll}\text { 4.4. RESULTS } & 69\end{array}$

4.4.1. Petrography, whole rock geochemistry and $\mathrm{Sr}-\mathrm{Nd}-\mathrm{Pb}$ isotopes of the 69 Hatillo stock and el Bosque batholith

4.4.2. Zircon $\mathrm{U}-\mathrm{Pb}$ ages and $\mathrm{Hf}$ isotopes 71

$\begin{array}{ll}\text { 4.4.3. Volcanoclastic rocks } & 74\end{array}$

4.4.3.1. Pre-Paleogene zircons 74

4.4.3.2. Early Paleogene zircons

4.5. DISCUSSION

$\begin{array}{ll}\text { 4.5.1. Origin of the Paleogene plutonism } & 75\end{array}$

$\begin{array}{lr}\text { 4.5.2. Detrital zircon signatures } & 80\end{array}$

4.6. CONCLUSIONS 81

Capítulo 5. Magnetic fabric (AMS, AAR) of the Santa Marta batholith (northern Colombia) and the shear deformation along the Caribbean plate margin

$\begin{array}{ll}\text { ABSTRACT } & 82\end{array}$

5.1. INTRODUCTION

5.2. GEOLOGICAL SETTING 84

5.2.1. Early Paleogene magmatism in the Sierra Nevada de Santa Marta 86

5.3. U-Pb ZIRCON (SHRIMP) GEOCHRONOLOGY 88

$\begin{array}{ll}\text { 5.3.1. Sampling and methods } & 88\end{array}$

$\begin{array}{ll}\text { 5.3.2. Results } & 89\end{array}$

5.4. ANISOTROPY OF SUSCEPTIBILITY AND ANHYSTERETIC 90 REMANENCE 
5.4.1. Background 90

5.4.2. Sampling and Methods 91

$\begin{array}{ll}\text { 5.4.3. Magnetic susceptibility and mineralogy } & 92\end{array}$

$\begin{array}{ll}\text { 5.4.4. Anisotropy of magnetic susceptibility } & 94\end{array}$

5.4.5. Anisotropy of anhysteretic Remanence 95

$\begin{array}{ll}\text { 5.5. DISCUSSION } & 98\end{array}$

$\begin{array}{ll}\text { 5.5.1. Significance of magnetic fabrics } & 98\end{array}$

$\begin{array}{ll}\text { 5.5.2. Emplacement structures and tectonic implications } & 100\end{array}$

5.6. CONCLUSIONS 102

$\begin{array}{lr}\text { Capítulo 6. Discussão } & 103\end{array}$

$\begin{array}{ll}\text { Capítulo 7. Conclusões } & 108\end{array}$

$\begin{array}{lr}\text { Referências } & 110\end{array}$

$\begin{array}{ll}\text { ANEXOS. Tabelas de dados } & 131\end{array}$

Tabela 2.1. U-Pb zircon ages from the Tierradentro unit. 132

$\begin{array}{ll}\text { Tabela 2.2. U-Pb detrital zircon ages from the Cajamarca Complex. } & 137\end{array}$

Tabela 2.3. Zircon Hf isotope data from the Tierradentro gneisses and amphibolites and micaschist from the Cajamarca Complex.

Tabela 3.1. U-Pb zircon ages from the Payandé, Ibagué and Mariquita plutons.

Tabela 3.2. Hf isotopic data from the Payandé, Ibagué and Mariquita plutons.

Tabela 3.3. Geochemistry of major, trace and rare earth elements of the Payandé, Ibagué and Mariquita plutons.

Tabela 3.4. Whole rock $\mathrm{Nd}, \mathrm{Pb}$ and $\mathrm{Hf}$ isotopic analyses of the Payandé, Ibagué and Mariquita plutons.

Tabela 4.1. Whole rock geochemistry and $\mathrm{Sr}, \mathrm{Nd}$ and $\mathrm{Pb}$ isotopes from the Hatillo and El Bosque plutons.

Tabela 4.2. Zircon U-Pb geochronology results. 166

$\begin{array}{ll}\text { Tabela 4.3. Zircon Hf isotope results. } & 175\end{array}$

Tabela 5.1. SHRIMP U-Pb zircon data of a tonalite from the Santa Marta batholith.

Tabela 5.2. AMS parameters of the Santa Marta batholith. 


\section{LISTA DE FIGURAS}

Figura 1.1. Arcabouço geológico da Colômbia (encarte) com destaque para

Página as principais feições geológicas da Cordilheira Central (CC). WC, Cordilheira Ocidental; EC, Cordilheira Oriental; SNMS, Sierra Nevada de Santa Marta; RFS, sistema de falha de Romeral.

Figura 1.2. Reconstrução esquemática do desmembramento borda ocidental da Pangea no Triássico. Fragmentos do arco permiano estão preservados do México ao Peru, com a Cordilheira Central (Colômbia) - Real (Equador) contendo rochas do arco permiano e do estágio rifte triássico (in Spikings et al., 2015).

Figura 1.3. Migração da placa do Caribe entre o Cretáceo e o Paleoceno. O plateau oceânico do Caribe-Colômbia (CCOP) colide com o continente Sulamericano em trono de 75 Ma favorecendo a acresção de terrenos oceânicos na borda noroeste da Placa Sul-americana. Dioritos, tonalitos e granodioritos (triângulo vermelho) formados por subducção foram originados tanto em arco oceânico como continental (modificado de Weber et al., 2015).

Figura 2.1. Geology of the Central Cordillera (CC) in Colombia and Cordillera Real in Ecuador, showing the distribution of Cretaceous metamorphic and volcanic rocks, Jurassic continental arc intrusions: Abitagua (AB), Ibagué (IB), Mocoa (MB) and Segóvia (SB) batholiths and Permo-Triassic rocks. Inset - Main geological domains of Colombia highlighting the location of the Western (WC) and Eastern (EC) Cordilleras.

Figura 2.2. Detailed geological map of the study area, showing the samples distribution (squares) and the relations between the studied units.

Figura 2.3. U-Pb ages and Concordia diagram obtained from zircon rims representing the crystallization age of the CI12 sample (Quartz-feldspathicgneiss). Scale bar on CL image is $100 \mu \mathrm{m}$.

Figura 2.4. U-Pb ages and Concordia diagram obtained zircon rims representing the metamorphic age of the CAT1A sample (amphibolite). Scale bar on CL image is $100 \mu \mathrm{m}$.

Figura 2.5. U-Pb zircon ages and Concordia diagram obtained from sample GCC8 (augen granodiorite) whose age is in the same range of sample CAT1A.

Figura 2.6. U-Pb detrital zircon results from the quartz-muscovite schist (CH21C), showing less than 30\% discordance and less than $10 \%$ discordance for comparison.

Figura 2.7. Upper: Distribution of the whole $\varepsilon_{\mathrm{Hf(i)}}$ obtained for the Cajamarca Complex. Lower: Initial $\varepsilon_{\mathrm{Hf}}$ vs. ${ }^{206} \mathrm{~Pb} /{ }^{238} \mathrm{U}$ age diagram. Squares 
represents zircons from sample CAT1A (amphibolite) with a strong juvenile signature as opposite to the zircons from the sample CI12 (hornblende gneiss) represented by triangles, which reflects the involvement of crustal sources for this rock. Circles are from detrital zircons of the Tahamí terrane. See the comparison with published data from other Middle Jurassic plutons of the Central and Northern Andes [Ilo batholith: Boekhout et al. (2012). Payandé and Ibagué plutons: Bustamante et al. (2016); Cochrane et al. (2014b)].

Figura 3.1. A: Distribution of the Jurassic plutonic belt in the Northern Andes. B: Detailed map of the occurrences of Lower Jurassic to Lower Cretaceous plutonic rocks in the Central Cordillera of Colombia and isolated massifs with associated volcanic rocks.

Figura 3.2. Representative Scanning Electron Microscope Cathodoluminescence (SEM-CL) images from zircon grains of each pluton studied. Upper: Payandé stock, middle: Ibagué batholith, bottom: Mariquita stock.

Figura 3.3. U-Pb zircon ages with $1 \sigma$ box heights and Tera-Wasserburg diagrams with $68.3 \%$ confidence error ellipses from the Payandé stock.

Figura 3.4. U-Pb zircon ages with $1 \sigma$ box heights and Tera-Wasserburg diagrams with $68.3 \%$ confidence error ellipses from the Ibagué Batholith.

Figura 3.5. U-Pb zircon ages with $1 \sigma$ box heights and Tera-Wasserburg diagrams with $68.3 \%$ confidence error ellipses from the Mariquita stock.

Figura 3.6. Harker diagrams of the three studied plutons, showing how fractional crystallization is a common process among them.

Figura 3.7. Geochemical classification and discrimination diagrams of samples from the three studied plutons. A: Classification of plutonic rocks based on the TAS diagram of Cox et al. (1979). B: Alkalinity index diagram of Pecerillo and Taylor (1976). C: Alumina saturation index diagram of Shand (1943).

Figura 3.8. Multi-element plot normalized to primitive mantle according to Sun and McDonough (1989).

Figura 3.9. Chondrite normalized REE patterns according to Nakamura (1974).

Figura 3.10. Map from Colombia showing the distribution of the JurassicCretaceous magmatic belt. U-Pb zircon ages from this study and other works are plotted in rectangles. 1: Leal-Mejía (2011); 2: Bustamante et al. (2010); 3: Villagómez et al. (2011); 4: Álvarez-Galíndez (2013). Lower to midCretaceous mafic magmatism is represented by white (Yavi Fm.: Toro-Toro et al., 2011) and black (Eastern Cordillera: Vásquez and Altenberger, 2005) squares. 
Figura 3.11. Detrital U-Pb zircon ages from boreholes showing that the density of ages is higher for the Lower to Middle Jurassic and decreases towards the Upper Jurassic to Lower Cretaceous, which is consistent with a decreasing volume of magma. Data are compiled from Nie et al. (2010), Horton et al. (2010), Saylor et al. (2011), Bayona et al. (2013), Caballero et al. (2013) and Silva et al. (2013).

Figura 3.12. LREE/HREE ratios and alkalis content ( $\mathrm{K} 2 \mathrm{O}$ and $\mathrm{Na} 2 \mathrm{O}$ ) over time.

Figura 3.13. Discrimination diagram of granites (Hf-Rb/30-Ta*30) according to Harris et al. (1986).

Figura 3.14. Lead isotopic evolution curve according to the plumbotectonics model of Zartman and Doe (1981).

Figura 3.15. Variation of initial $\varepsilon_{\mathrm{Hf}}$ and ${ }^{176} \mathrm{Hf} /{ }^{177} \mathrm{Hf}$ in zircon and whole rock with ${ }^{206} \mathrm{~Pb} /{ }^{238} \mathrm{U}$ crystallization age. Triangles and rotated crosses: Mariquita stock zircon and whole-rock data, respectively; Diamonds and crosses: Ibagué Batholith zircon and whole-rock data, respectively; Squares and star: Payandé stock zircon and whole-rock data, respectively; Dark grey rectangles: data from Colombian granites; Light grey rectangles: data from Ecuadorian granites (Cochrane et al., 2014b).

Figura 3.16. Initial $\varepsilon_{\mathrm{Hf}}$ vs. $\varepsilon_{\mathrm{Nd}}$ diagram. Symbols same as in fig. $13 . \mathrm{Hf}-\mathrm{Nd}$ mantle array from Vervoort and Blichert-Toft (1999).

Figura 3.17. Model proposed (not to scale) for the generation of the Early Jurassic to Early Cretaceous magmatic arc in the Northern Andes of Colombia. The figure shows the relationship between oblique convergence, clastic input, and basalt+sediment melting of the crust to form granodioritic batholiths (modified from Castro, 2014).

Figura 4.1. A. Location of Paleogene igneous bodies sampled in Western and Central Cordillera and Paleogene detrital zircons sampled in Eastern Cordillera of Colombia; B. Regional cross section of Central Colombia with Paleogene samples; C. Sedimentary section with detrital samples analyzed. Figure modified from Bayona et al. (2012).

Figura 4.2. Prismatic epidote crystal in the Hatillo stock. Vertical length is $2.7 \mathrm{~mm}$ for each phtotograph.

Figura 4.3. Geochemical classification and discrimination diagrams of samples from the studied plutons. A: Alkalinity index diagram of Pecerillo and Taylor (1976). B: Alumina saturation index diagram of Shand (1943). C: Multi-element plot normalized to primitive mantle according to Sun and McDonough (1989). D: Hf-Rb/30-Ta*3 geotectonic discrimination diagram of Harris et al. (1986). E: Chondrite normalized REE patterns according to Nakamura (1974). 
Figura 4.4. CL images from representative zircons from the Hatillo (upper) and El Bosque (lower) plutons.

Figura 4.5. U-Pb Concordia ages obtained from plutons of the Central Cordillera: Hatillo stock and El Bosque batholith.

Figura 4.6. Initial $\varepsilon_{\mathrm{Hf}} \mathrm{vs}{ }^{206} \mathrm{~Pb} /{ }^{238} \mathrm{U}$ age. Data from Paleogene igneous and detrital zircons from Central and Eastern Cordilleras of Colombia.

Figura 4.7. Hf isotope data from pre-Paleogene (>66 Ma) detrital zircons of the Bogotá Formation.

Figura 4.8. Sr/Y vs $\mathrm{Y}$ diagram after Defant and Drummond (1990) for adakite rocks discrimination.

Figura 4.9. Variation of crustal depth with age in the western margin of the Colombian Andes during the Meso-Cenozoic. Blue points represent the whole data used to show the variations after applying the filters suggested by Profeta et al. (2015). Green line is an average every 10 Ma. Relations between Sr/Y ratio and depth are according to Profeta et al. (2015).

Figura 4.10. A. $\varepsilon_{\mathrm{Nd}(\mathrm{i})}$ vs ${ }^{87} \mathrm{Sr} /{ }^{86} \mathrm{Sr}$. B. Lead isotopic evolution curve according to the plumbotectonics model of Zartman and Doe (1981). Both diagrams show a comparing between the Eocene plutons analyzed with other Paleogene plutons from the Central Cordillera and the Colombian Caribbean.

Figura 5.1. Caribbean oceanic plateau bounded by the subduction zones of Antilles and Panamá, and strike-slip (transform) faults. Accreted oceanic terranes related to the oblique subduction of the Caribbean plate beneath South America are shown to the Ecuador, Colombia and Panama to the west of the Romeral fault system. 1. Cretaceous oceanic rocks; 2, thrust; 3, subduction zone (modified from Kerr, 2014).

Figura 5.2. Simplified physiographic map of the northern Andes showing the Cretaceous oceanic rocks of the West Cordillera (WC) in contact with the Central Cordillera along the Romeral fault system. The Eastern Cordillera (EC) is separated from the Sierra Nevada de Santa Marta (SNSM) block and Central Cordillera by sedimentary deposits of the César-Rancheria and Magdalena basins. Plutonic rocks corresponding to the Paleocene-Eocene magmatic arc are shown in red (modified from Bayona et al., 2012).

Figura 5.3. Geological map of the eastern part of the Sierra Nevada de Santa Marta.

Figura 5.4. AMS sampling sites with the domain with the granitoid with foliated and/or gneissic microstructure (modified from Tschanz et al. (1969). The location of the sites with geochronological determinations after Duque (2009) and Cardona et al. (2011a).

Figura 5.5. Cathodoluminescence images of representative zircons of a 
horblende-biotite tonalite (sample SM54). Some grains show dark (U-rich) cores (left) enclosed by more luminescent (and low U) rims. Oscillatory zoning typical of magmatic zircons are visible in cores and rims.

Figura 5.6. Concordia diagram of the hornblende-biotite tonalite, with the zircon age determined by average of the concordant data. Analyses corresponding to the grey ellipses were discarded from the age calculation (see text).

Figura 5.7. Relation between the mean-site magnetic susceptibility $(\mathrm{Km})$, degree of anisotropy (P) and shape (T) of the AMS ellipsoid.

Figura 5.8. Dependence of the magnetic susceptibility with temperature for representative samples of the Santa Marta batholith.

Figura 5.9. Magnetic fabric (foliation and lineation) and domains where the rock microstructure is foliated and/or gneissic (grey area). Dashed line corresponds to the corridors where the foliation trend is nearly E-W. Stereonets of the magnetic lineation (right) and pole of the magnetic foliation (Schmidt diagrams, lower hemisphere; contours of 2\%, 4\%, 1\% area). Black; xenolith. ND and SD; northern and southern domain.

Figura 5.10. Coercivity spectra for samples with different susceptibility magnitudes ( $\mathrm{k}, 10-3 \mathrm{SI})$. Grey areas indicate the windows chosen to determination of partial anisotropy of anhysteretic remanence. $\mathrm{H}$, induced field, ARM; normalized anhysteretic remanent magnetization.

Figura 5.11. Stereograms (lower hemisphere) of the principal directions of AMS and partial AAR for sites with moderate to strong magnetic susceptibility magnitudes.

Figura 5.12. Stereograms (lower hemisphere) of the principal directions of AMS and partial AAR for sites with low magnetic susceptibility magnitudes (symbols as in Fig. 5.11).

Figura 5.13. Tectonic model of the Santa Marta batholith (upper left) combining the trend of magnetic foliation (red lines) and the metamorphic fabric of the host-rocks (after Tschanz et al., 1969). Dashed lines correspond to the synthetic shear bands originated by the regional strain field dominated by dextral shear. The shear component is transmitted to the magmatic arc (lower right) by the oblique subduction of the Caribbean plate. 


\section{Capítulo 1}

\section{Introdução}

\subsection{ORGANIZAÇÃO DA TESE}

Após a apresentação do contexto geológico no qual a tese se desenvolve, introduzimos os conceitos e ideias fundamentais da evolução tectônica dos Andes do Norte sob a perspectiva da evolução magmática, e com foco na Cordilheira Central da Colômbia. Nessa introdução estão ainda descritos os objetivos que justificaram a realização deste trabalho bem como os métodos analíticos utilizados para alcançar os objetivos propostos.

A apresentação dos resultados se dá sob a forma de artigos científicos submetidos a periódicos internacionais. Embora conectados pelo tema geral que fundamenta a pesquisa, cada artigo pode ser lido de forma independente em cada capítulo da tese.

$\mathrm{O}$ capítulo 2 compreende o artigo intitulado " $\mathrm{U}$-Pb ages and $\mathrm{Hf}$ isotopes in zircons from Para-Autochthonous Mesozoic terranes in the western margin of Gondwana: implications for the terrane configurations in the Northern Andes", submetido ao periódico The Journal of Geology. O manuscrito trata da conformação do embasamento PermoTriássico da Cordilheira Central e sua relação com o cinturão metamórfico Jurassico, explorando suas implicações na definição dos terrenos tectonoestratigráficos da Colômbia.

O capítulo 3 está submetido ao periódico Geological Society of America Bulletin sendo intitulado "Late Jurassic to Early Cretaceous plutonism in the Central Cordillera of the Colombian Andes: a record of long-term arc maturity”. Ele aborda a origem, distribuição e evolução do cinturão plutônico Jurássico-Cretáceo da Cordilheira Central e discute os mecanismos de "slab roll-back" relacionados à subducção da placa do Pacífico.

O capítulo 4 refere-se ao artigo "Geochemistry and isotopic signatures of Paleogene plutonic and detrital rocks of the Northern Andes of Colombia: a record of post-collisional arc magmatism”, submetido ao periódico Lithos. Esse artigo discute a gênese do plutonismo Paleógeno da Cordilheira Central, o registro do magmatismo na proveniência dos zircões detríticos das bacias a leste da Colômbia, e a relação entre o arco magmático Paleógeno na Cordilheira Cenral com a tectônica do Caribe.

O capítulo 5 trata da colocação do batólito Santa Marta no arco magmático Paleógeno formado pela interação da placa do Caribe com o continente Sul-Americano. Utilizamos a 
técnica da anisotropia de suceptibilidade magnética (ASM) para caracterizar as estruturas do batólito e entender o alojamento de magmas em uma margem ativa. $\mathrm{O}$ artigo denominado "Magnetic fabric (AMS, AAR) of the Santa Marta batholith (northern Colombia) and the shear deformation along the Caribbean plate margin" foi submetido ao Journal of South American Earth Science e encontra-se em fase de revisão

O capítulo final procura consolidar os resultados descritos nos capítulos anteriores para apresentar um quadro geral da história tectônica da Cordilheira Central da Colômbia entre o Jurássico e o Eoceno. São discutidos os modelos atuais da evolução da parte norte da cadeia andina e suas implicações para a acrescão continental ao longo da margem colombiana. Finalmente, as conclusões abrangem os principais resultados obtidos no presente trabalho.

\subsection{CONTEXTO GEOLÓGICO REGIONAL}

A margem noroeste de América do Sul durante o Meso-Cenozóico é o resultado de uma sucessão de ambientes tectônicos distintos, que incluem subducção e acresção/colisão de terrenos. A convergência entre a placa Sul-Americana e placas oceânicas de origem diversa (e.g., Pacífico, Caribe, Nazca) moldaram a estrutura atual do orógeno Andino (Toussaint, 1995; Jaillard et al., 2000; Ramos \& Aleman, 2000; Ramos, 2009; Pindell \& Keenan, 2010). Os modelos tectônicos regionais consideram que a subducção da litosfera oceânica ao longo da margem noroeste da América do Sul foi acompanhada de mudanças drásticas quanto à origem da placa e o seu modo de convergência no tempo. Durante o Meso-Cenozóico a convergência consumiu essencialmente uma placa de afinidade pacífica, enquanto no Paleoceno-Eoceno toda a margem norte do continente foi afetada pela convergência oblíqua da plateau do Caribe (Kerr et al., 1997; Pinell \& Kennan, 2009; Kerr, 2014). A partir do Mioceno foi restabelecido no Pacífico a subducção da Placa Farallones (atual Placa Nazca; Ramos, 2009). A placa do Caribe, por sua vez, está atualmente separada do Pacífico e Atlântico pelos arcos vulcânicos da América Central e Antilhas, respectivamente. A migração para nordeste e leste da placa caribenha define ainda as zonas tranformantes de HispaniolaPorto Rico a norte (Calais et al., 2016) e, na Venezuela a sul, a de Oca-Cordilheira da Costa (Escalona and Mann, 2011). 


\subsubsection{Arcabouço tectônico da Colômbia}

A geologia colombiana pode ser compreendida em termos de três grandes cordilheiras, a oriental, central e ocidental (Figura 1.1) separadas a leste por bacias pós-paleozoicas e pela vasta planície amazônica. Na extremidade oriental do país afloram núcleos precambrianos correlacionados ao Cráton Amazônico.

As rochas mais antigas das cordilheiras estão expostas na Cordilheira Oriental e na região de Sierra Nevada de Santa Marta (SNSM, Figura 1.1), que ocorrem como blocos isolados e dispersos de idade Grenviliana (Restrepo-Pace et al., 1997). A Cordilheira Oriental contém, portanto um embasamento Precambriano sucedido por rochas metasedimentares de afinidade oceânica depositados no Paleozóico Inferior. Estudos recentes baseados em geoquímica isotópica e geocronologia $\mathrm{U}-\mathrm{Pb}$ em zircào indicam um embasamento autóctone de afinidade Gondwanica para a Cordilheira Oriental, com a subducção no Ordoviciano do oceano Iapetus-Rheic promovendo a intrusão de rochas magmáticas, metamorfismo e deformação no embasamento da Cordilheira Oriental (Van der Lelij et al., 2016). A bacia dos Llanos limita a borda leste da Cordilheira Oriental enquanto exposições locais do cráton Amazônico ocorrem perto da fronteira com o Brasil. 


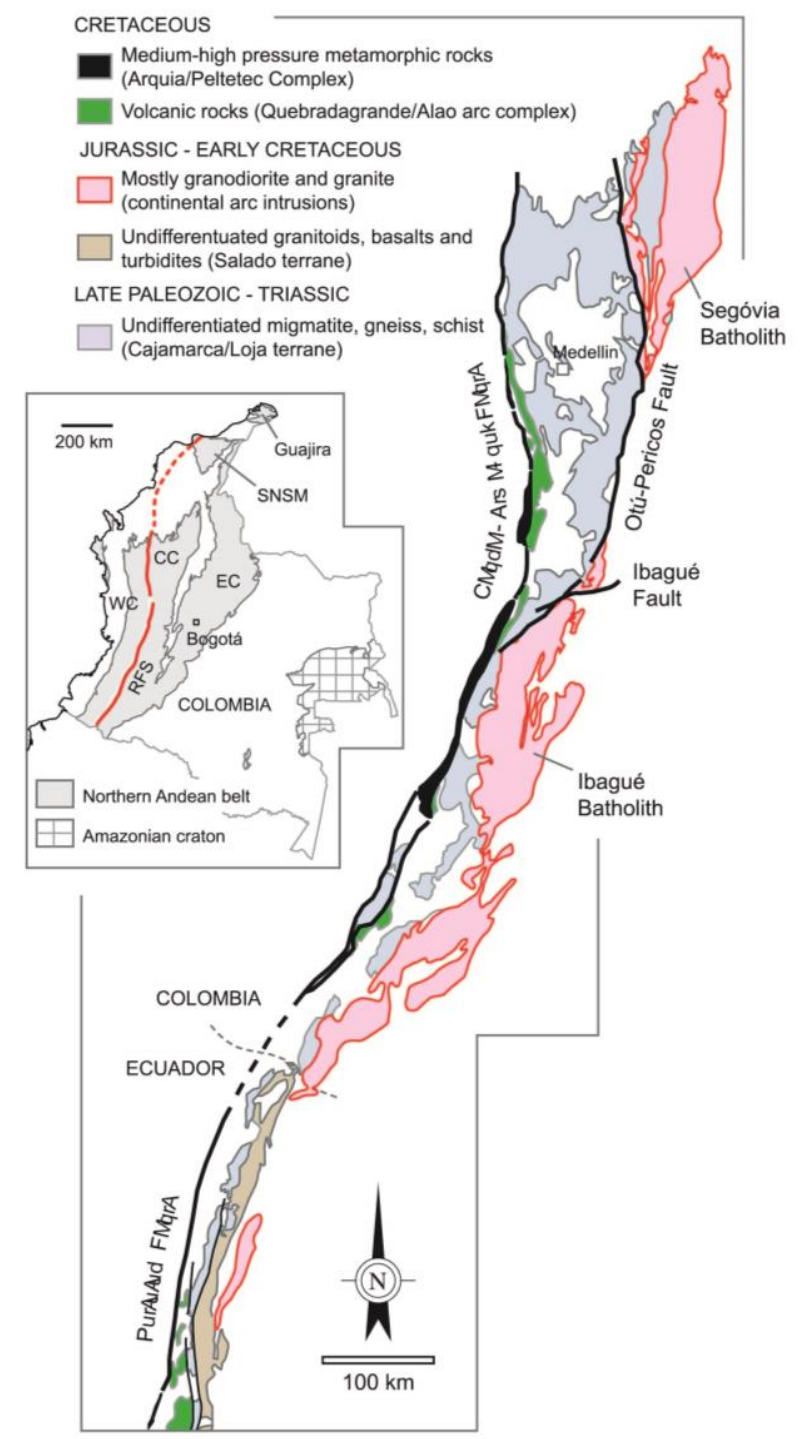

Figura 1.1. Arcabouço geológico da Colômbia (encarte) com destaque para as principais feições geológicas da Cordilheira Central (CC). WC, Cordilheira Ocidental; EC, Cordilheira Oriental; SNMS, Sierra Nevada de Santa Marta; RFS, sistema de falha de Romeral.

A Cordilheira Central da Colômbia, objeto de estudo desta tese, consiste de um embasamento Permo-Triássico de afinidade dominantemente continental que evoluiu a partir da fragmentação da Pangea no Triássico Inferior (c. $240 \mathrm{Ma}$ ) com o desmembramento da América do Sul e da América Central. A borda noroeste da América do Sul permaneceu como uma margem passiva até o final do Triássico quando começa a subducção da placa do Pacífico (Spikings et al., 2015). A Cordilheira Central é limitada a oeste por rochas máficas cretácicas de afinidade oceânica reunidas no Complexo Quebradagrande. O contato entre as cordilheiras Ocidental e Central é feita pelas falhas de Cauca-Almaguer (Colômbia) e Peltetec 
(Equador), e que inclui sequências metamórficas de média-alta pressão do Complexo Arquia (Bustamante et al., 2012). As cordilheiras ocidental e central se prolongam para sul em direção ao Equador e Peru onde estão agrupadas na "Cordilheira Real".

Os processos que levaram a formação de granitoides tipo-S, migmatitos e anfibolitos que constituem as unidades de embasamento da Cordilheira Central foram formados entre 240 e 216 Ma (Cochrane et al., 2014a). Na Colômbia essas unidades estão reunidas no Complexo Cajamarca enquanto no Equador ao terreno Loja (Figura 1.1; Spikings et al., 2015). As reconstruções geodinâmicas sugerem a existência de um arco Parmiano que se estendeu do México ao Peru consumindo a placa do Pacífico até pelo menos o final do Jurássico. O arco foi submetido à extensão e desenvolvimento de bacias retro-arco no Permo-Triássico (Figura 1.2) antecendo à colocação no Jurássico de extenso e volumoso magmatismo. Na Cordilheira Central esse magmatismo está representado principalmente pelos batólitos de Segóvia e Ibagué, e na Cordilheira Real pelo batólito de Azafrán (Figura 1.1).

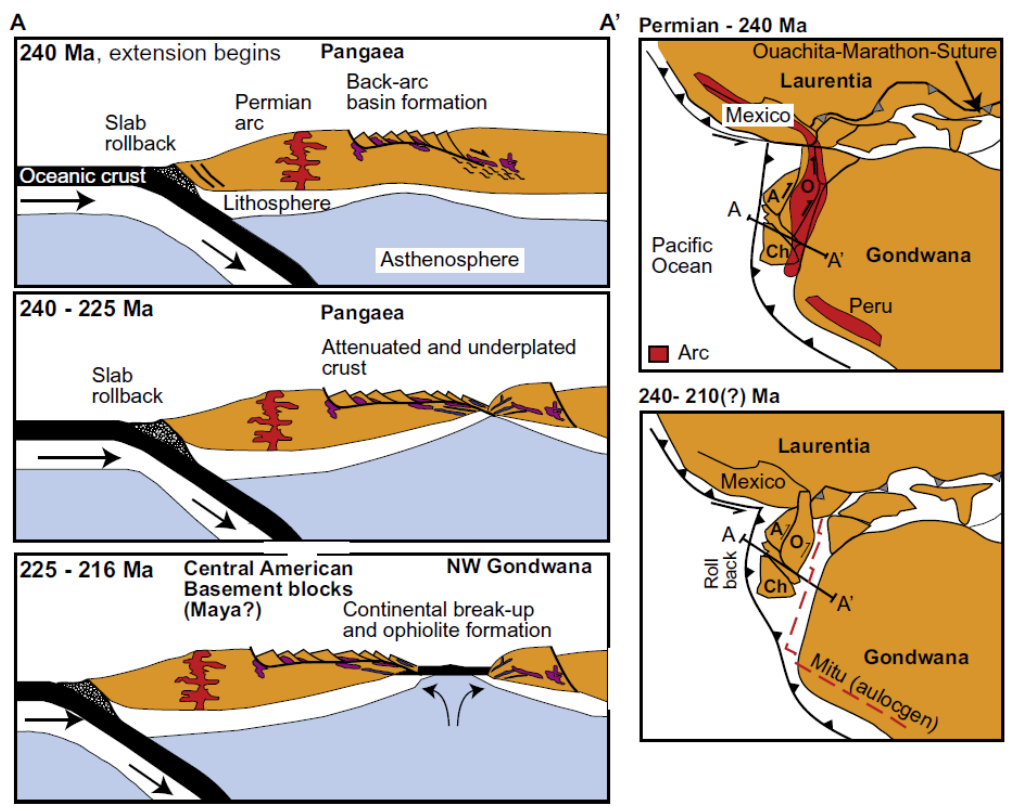

Figura 1.2. Reconstrução esquemática do desmembramento borda ocidental da Pangea no Triássico. Fragmentos do arco permiano estão preservados do México ao Peru, com a Cordilheira Central (Colômbia) - Real (Equador) contendo rochas do arco permiano e do estágio rifte triássico (in Spikings et al., 2015).

Restrepo e Toussaint (1988) sugeriram que a margem da Colômbia poderia se entendida em termos de "terrenos alóctones" e definiram os terrenos Tahamí e Chibcha para as Cordilheiras Central e Oriental, respectivamente. A falha de Otú-Pericos (Figura 1) separaria os terrenos Tahami e Chibcha, sendo que este último conteria os fragmentos do embasamento Grenviliano e estariam registrados os eventos tectono-metamórficos pré- 
ordovicianos. O modelo de "terrenos" aplicado a Cordilheira Oriental foi recentemente contestado por Van der Lelij et al. (2016) e, nessa tese (Capítulo 2), apresentamos evidências geoquímicas e geocronológicas de que a falha de Otú-Pericos não representa um limite onde a evolução geológica seria distinta nos lados opostos da falha. Rochas permo-triássicas foram ainda reconhecidas a sul na Cordilheira Real no Equador, e a norte na Sierra Nevada de Santa Marta e na península de Guajira.

A Cordilheira Central é separada da Cordilheira Ocidental pelas falhas de CalcaAlmaguer-Peltetec, que reunidas definem o Sistema de Falhas de Romeral (RFS, Figura 1). A RFS é delineada por unidades litológicas diferenciadas de idade diversa tais como: (i) rochas vulcano-sedimentares do Cretáceo Inferior (Complexo Quebradagrande/Alao; Villagomez et al., 2011), (iii) metapelitos, intrusivas máficas e serpentinitos do Permo-Triássico, e (iii) intrusivas máficas e ultramáficas, metapelitos e quartzitos de média-alta pressão (Complexo Arquia/Peltetec) que incluem ocorrências de xistos com glaucofana cujas idades ${ }^{40} \mathrm{Ar} /{ }^{39} \mathrm{Ar}$ situam-se em torno de 120 Ma (Bustamante et al., 2012). Essa unidades estiradas e segmentadas na RFS definem, portanto uma mélange ou uma zona de sutura entre as cordilheiras Central e Ocidental.

A Cordilheira Ocidental compreende rochas de afinidade oceânica (vulcânicas máficas e ultramáficas com química de MORB e arco oceânico, sedimentos de água profunda) formadas no Cretáceo. Essas unidades foram reunidas por Restrepo e Toussaint (1988) no Terreno Calima. A acresção do terreno Calima ao continente começou no Campaniano com a convergência obliqua da placa do Caribe (Figura 1.3). As reconstituições palinspáticas de Pindell and Kennan (2009) indicam que desde o Cretáceo pelo menos $1.600 \mathrm{~km}$ da litosfera caribenha subductou sob a Colômbia e Venezuela, e que entre 85 e 45 Ma o continente acomodou pelo menos $1.000 \mathrm{~km}$ de deslocamento lateral com movimento para nordeste do plateau do Caribe. A subducção originou um plutonismo de arco oceânico e continental com a intrusão, entre o Cretáceo Superior e Paleoceno, de dioritos, tonalitos e granodioritos (Weber et al., 2015). A magmatismo cessa em torno de 45 Ma provavelmente pela dificuldade da espessa litofera oceânica subductar sob a América do Sul. 

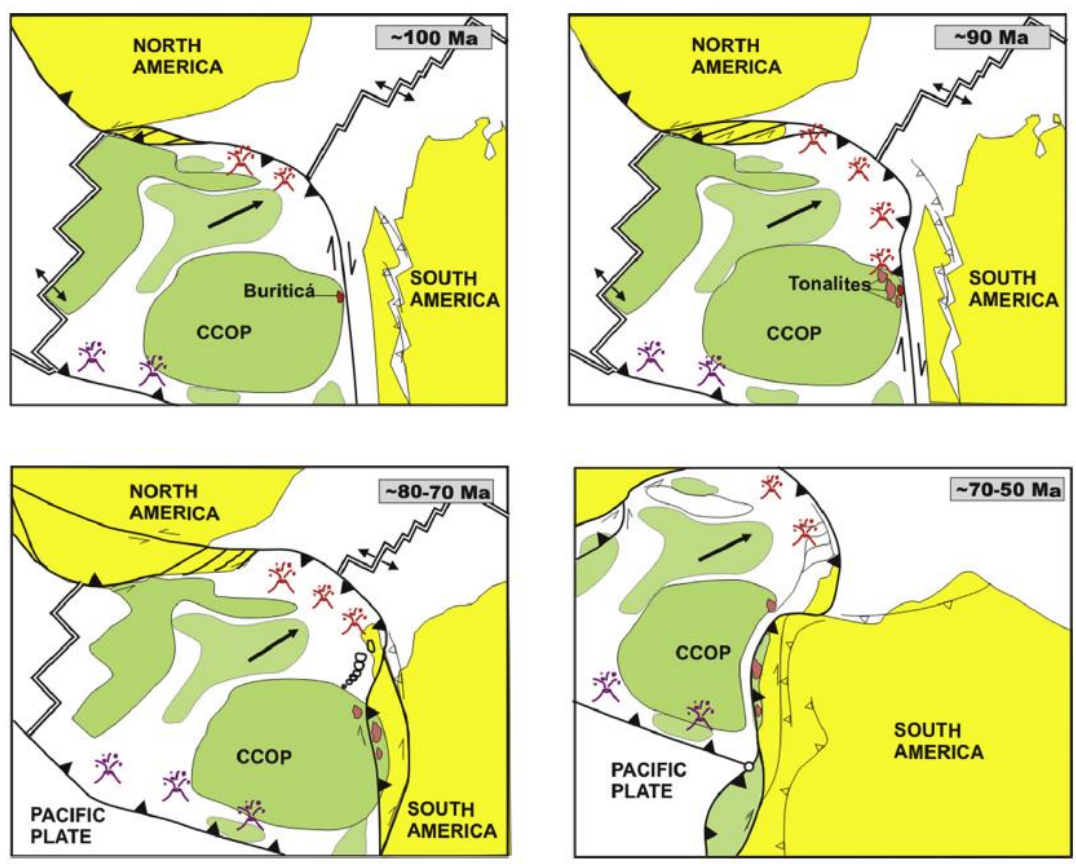

Figura 1.3. Migração da placa do Caribe entre o Cretáceo e o Paleoceno. O plateau oceânico do CaribeColômbia (CCOP) colide com o continente Sulamericano em trono de 75 Ma favorecendo a acresção de terrenos oceânicos na borda noroeste da Placa Sul-americana. Dioritos, tonalitos e granodioritos (triângulo vermelho) formados por subducção foram originados tanto em arco oceânico como continental (modificado de Weber et al., 2015).

\subsubsection{Magmatismo Meso-Cenozóico na Cordilheira Central}

O magmatismo resultante da complexa evolução tectônica acima mencionada tem sido relativamente pouco explorado, particularmente na Colômbia. Uma compilação e síntese das idades radiométricas do magmatismo cálcio-alcalino Meso-Cenozóico foi apresentado por Aspden et al. (1987). A cronologia do magmatismo, entretanto, está fundamentada no método $\mathrm{K}-\mathrm{Ar}$ que, além da imprecisão inerente ao sistema isotópico, foi aplicado em corpos que aparentam ter sofrido sucessivos eventos de reaquecimento, o que limita, portanto a interpretação dos dados. Trabalhos mais sistemáticos com base em modelos da evolução magmática que reunem dados petrológicos, geoquímicos, geocronológicos e tectônicos foram desenvolvidos em áreas do Equador e Colombia (Villagómez et al., 2011; Cochrane et al., 2014b) embora poucos corpos magmáticos dos Andes da Colômbia tenham sido estudados em detalhe. As únicas exceções são os plútons eocênicos de Santa Marta e Parashi situados no Caribe Colombiano: (Tschanz et al., 1974; Duque, 2009; Cardona et al., 2011a). Outro batólito bem estudado é o Antioqueño, notadamente sua petrografia (Feininger \& Botero, 1982), e ainda sobre o qual estão localmente disponíveis dados radiométricos e geoquímicos (Ordóñez \& Pimentel, 2001; Ibañez-Mejia et al. 2007; Restrepo-Moreno et al. 2007; Ordóñez-Carmona et al. 2007; Leal-Mejia, 2011). Os dados do batólito Antioqueño, porém 
foram disponibilizados apenas em apresentações de congressos e ainda não foram discutidos e integrados dentro de um modelo coerente. Estudos regionais que também trazem novos dados isotópicos e geoquímicos de diferentes plútons Meso-Cenozóicos podem ser encontados nos trabalhos de Villagómez et al. (2011), Bayona et al. (2012), Cochrane et al. (2014b) e Spikings et al. (2015). Destaca-se ainda o trabalho de Leal-Mejia (2011), que propôs um modelo para a evolução metalogenética na Colômbia durante o Fanerozoico.

Os dados geoquímicos disponíveis sugerem para a Cordilheira Central um ambiente tectônico de subducção em regime de extensão no back-arc e intra-ar do Jurássico Inferior até o Cretáceo Inferior (Aspden et al., 1987; Bayona et al., 2006; Bustamante et al., 2010; Villagómez et al., 2011). A evolução do magmatismo neste período tem sido relacionado a migração de arco para o oceano devido ao mecanismo de slab-roll back da placa descendente (Cochrane et al., 2014b). Contudo, este modelo vem sendo questionado pela possível translação de terrenos situados em latitudes mais ao sul, o que poderia ter justaposto diferentes domínios jurássicos na mesma latitude (Bayona et al., 2006). Além disso, evidências para uma fase compressiva associada a metamorfismo regional no Jurássico Superior têm sido documentadas na encaixante ocidental do batólito de Ibagué (BlancoQuintero et al., 2014). As idades U-Pb em zircão de rochas plutônicas forneceram para o magmatismo uma idade entre 190 e 145 Ma (Bustamante et al., 2010; Villagómez et al., 2011; Leal-Mejía, 2011; Álvarez-Galindez, 2013; Cochrane et al., 2014b).

Diferentes autores reconheceram a ausência do registro plutônico (na Cordilheira Central) ao final do Jurássico e início do Cretáceo. Aspden et al. (1987) reportam um hiato no magmatismo entre 142 e 124 Ma, o qual relacionaram a um ângulo baixo entre a subducção da placa oceânica sob a continental. Além disso, os dados mais recentes de Villagómez et al. (2011) não registram a presença de rochas magmáticas com idades em torno de $145 \mathrm{Ma}$, o que foi relacionado à acresção de seamounts atualmente preservados no embasamento da Cordilheira Central (i.e., Complexo Quebradagrande). Outra possibilidade seria a de um regime de convergência extremamente oblíquo ao final do Jurássico, o que impediria a geração do magmatismo de arco (Kennan e Pindell, 2009). Uma situação similar é reportada nos Andes do Equador com a ausência de registro de magmático no Cretáceo Inferior (Chiaradia et al., 2009). O ressurgimento do magmatismo de arco continental na margem NW da Colômbia é marcada pelo Batólito Antioqueño em torno de $90 \mathrm{Ma}$, o qual tem sido relacionado à subducção do proto-Caribe (Ibañez-Mejía et al., 2007; Ordóñez-Carmona et al., 2007; Leal-Mejía et al., 2010; Villagómez et al., 2011). Esse magmatismo continuou durante 
o Paleogeno, mas como produto da subducção do plateau do Caribe sob a margem NW da placa Sul-Americana. Os corpos magmáticos intrudem uma zona relativamente estreita na Cordilheira Central e Ocidental (Montes et al., 2012; Bayona et al., 2012), com algumas manifestações restritas no oeste da Colômbia (Bayona et al., 2012). Também no Caribe Colombiano, especialmente nas regiões de Santa Marta e Guajira, afloram plútons eocênicos que resultaram da subducção da Placa do Caribe (Cardona et al., 2011; Cardona et al., 2014). Segundo o registro de idades U-Pb em zircão, o magmatismo cessa no Eoceno Meio possivelmente devido a dificuldade de subductar a espessa litosfera do plateau do Caribe. O "bloqueio" da subducção favoreceria a convergência oblíqua da placa do Caribe bem como a mudança no regime de deformação ao longo do arco para francamente transpressivo (Bayona et al., 2012; Kennan e Pindell, 2009).

Nesta tese propõe-se um modelo alternativo para a evolução tectono-magmática dos Andes Colombianos entre o Jurássico e o Eoceno. Incluímos uma discussão sobre embasamento do arco magmático da Cordilheira Central cujas implicações tectônicas se estendem até o Equador. São apresentados novos dados isotópicos U-Pb e Hf em zircão, geoquímica em rocha total e isótopos de $\mathrm{Sr}, \mathrm{Nd}, \mathrm{Pb}$ e $\mathrm{Hf}$ em rocha total de diferentes plútons localizados na Cordilheira Central da Colômbia. O estudo do embasamento permitiu rediscutir a validade do modelo de "terrenos alóctones" para os Andes Colombianos proposto por Toussaint e Restrepo, (1988) e Restrepo et al., (2011). Os resultados mostram que a Falha Otú-Pericos separa o embasamento Permo-Triássico (anteriormente considerado de idade Grenvilliana) de um cinturão metamórfico Jurássico até e tão desconhecido na Cordilheira Central (Capítulo 2).

Este embasamento Permo-Triássico a leste da Falha Otú Pericos encontra-se intrudido pelo magmatismo Jurássico. Embora o arco continental esteja relacionado à subducção da placa Farallón (Aspden et al., 1987), o mecanismo tectônico que originou os magmas é ainda controverso. Cochrane et al. (2014b) propuseram que o arco magmático migrou para o oceano através do slab roll-back da litosfera oceânica, com plutonismo terminando em 145 Ma. Nossos dados sugerem que o mecanismo de slab roll-back pode ter contribuído com o magmatismo apenas no início do processo com a subducção da mistura de sedimentos e basaltos favorecendo a fusão da cunha mantélica. O regime de subducção evoluiria sob uma componente progressivamente oblíqua entre 145 e 129 Ma, após o que o registro magmático é bruscamente interrompido (Capítulo 3). 
O magmatismo de arco retorna na Cordilheira Central em torno de $90 \mathrm{Ma}$ com a interação entre as placas do Caribe e Sul-Amricana. São apresentados aqui novos dados geoquímicos e isotópicos dos plútons eocênicos da Cordilheira Central. O modelo geodinâmico proposto considera uma diferenciação de magmas em regime de alta pressão em coerência com o espessamento da crosta após a colisão de arco oceânico e continente no Paleógeno (Capítulo 4). Zircões detríticos de bacias situadas no leste da Colômbia mostram idades U-Pb eocênicas com composições de Hf comparáveis aos da Cordilheira Central (Bayona et al., 2012). Finalmente, investigamos o mecanismo de colocação do batólito Santa Marta situado no Caribe Colombiano (Capítulo 5). As estruturas magmáticas do batólito são consistentes com o deslocamento para norte-nordeste (relativo à America do Sul) da placa do Caribe. Nesse contexto, o arco se deformou localmente em um regime cisalhante extensional favorecendo a ascenção de magmas. O flat slab que caracterizou este período foi determinante para que o desaparecimento do magmatismo no Eoceno Superior.

\subsection{JUSTIFICATIVA E OBJETIVOS}

As incertezas quanto à duração do magmatismo Meso-Cenozóico da Colômbia, a natureza da fonte, os processos geoquímicos e petrologicos dos magmas e as características de suas rochas encaixantes, devem ser mais bem exploradas com o estudo sistemático de plútons representativos no tempo geológico. Com isso, procuramos refinar os modelos de subducção e suas possíveis variações que marcaram a margem oeste da Colômbia.

Diante do exposto os objetivos desta tese são:

- Determinar a idade de cristalização e duração do magmatismo granítico através do estudo geocronológico utilizando o método U-Pb (LA-ICP-MS) em zircão;

- Definir o ambiente de formação e fonte dos diferentes magmas mediante análises geoquímicas de rocha total e análises isotópicas de $\mathrm{Hf}$ em zircão e de $\mathrm{Sr}, \mathrm{Nd}, \mathrm{Hf}$ e $\mathrm{Pb}$;

- Precisar a natureza do embasamento do plutonismo Jurássico e suas correlações regionais, particularmente investigando as características geológicas dos cinturões Grenvilliano e Permo-Triássico da Cordilheira Central;

- Reconstruir a evolução tectônica da margem convergente entre o Jurássico e o Eoceno na perspectiva o plutonismo de arco. 


\subsection{MATERIAIS E MÉTODOS}

Para atingir os objetivos propostos nesta tese de doutorado foram utilizados dados geoquímicos (elementos maiores e traços), isótopos de $\mathrm{Sr}, \mathrm{Nd}, \mathrm{Pb}$ e $\mathrm{Hf}$ em rocha total, e geocronologia U-Pb combinado a isótopos de $\mathrm{Hf}$ em zircão. Uma descrição geral destes métodos é apresentada a seguir. Informações adicionais podem ainda ser encontradas nos artigos que formam os Capítulos 2 a 5 . Os dados geoquímicos e geocronológicos apresentados nesta tese foram obtidos nos laboratórios da Washington State University.

\subsubsection{Geoquímica em rocha total}

As características composicionais das rochas ígneas plutônicas são controladas pela natureza das fontes (crosta e/ou manto), proporção ou o grau da fusão e possível participação dos fluidos, e os processos de diferenciação e contaminação posteriores. As fontes, por sua vez, apresentam variações composicionais relacionadas com o reservatório mantélico, o tipo de rocha e a profundidade onde ocorre a fusão (Faure \& Mensing, 2005). Esta complexidade pode se analisada mediante a integração da modelagem geoquímica (elementos maiores e traços) e isotópica, com uma apropriada temporalização do magmatismo e os elementos geológicos regionais.

Análises de elementos maiores, menores e traço em amostras de rocha total foram realizados mediante as técnicas e XRF (X-Ray Fluorescence) e ICP-MS (Inductively Coupled Plasma Mass Spectrometry). A informação geoquímica foi utilizada para classificação, discriminação e comparação das rochas através da construção de diagramas discriminatórios (Rollinson, 1993), que por sua vez fornecem informações sobre a evolução do magmatismo de arco.

As amostras selecionadas foram trituradas com um britador de mandíbula e pulverizadas utilizando um moinho de carboneto de tungstênio. Os elementos maiores e traços foram analisados com um espectrômetro Rigaku 3370 XRF. Detalhes da preparação de amostras, diluição e dos procedimentos analíticos para a obtenção dos elementos maiores e traços mediante fluorescência de raios X são descritos em Johnson et al. (1999). Para os elementos terras raras foram usados $2 \mathrm{~g}$ de amostra num cadinho de grafita misturados com $2 \mathrm{~g}$ de $\mathrm{LiBO}_{2}$, os quais foram fundidos a $1000{ }^{\circ} \mathrm{C}$ por 30 minutos. A pérola resultante foi moída num moino de aço e $0,25 \mathrm{mg}$ e foi dissolvida usando $\mathrm{HNO}_{3}(2 \mathrm{ml}), \mathrm{HF}(6 \mathrm{ml})$ e $\mathrm{HClO}_{4}(2 \mathrm{ml})$ a $110{ }^{\circ} \mathrm{C}$. As soluções da amostra foram aspiradas num ICP-MS (Perkins-Elmer Elan 6000) para determinação dos elementos traços, especialmente os elementos terras raras. 


\subsubsection{Geocronologia U-Pb LA-ICP-MS em zircão}

A geocronologia pelo método U-Pb em monocristais de zircão foi utilizada com $\mathrm{o}$ intuito de estabelecer a idade de cristalização magmática. Este método baseia-se na capacidade do Urânio (U) de substituir ao zircônio $(\mathrm{Zr})$ na estrutura cristalina do zircão (cf. Dickin, 1995) via decaimento radioativo. A transformação dos isótopos de $\mathrm{U}$ em $\mathrm{Pb}$ combinado à determinação das razões isotópicas do sistema pai-filho no espectrômetro de massa permite a definição da idade do mineral portados desses elementos.

O método do LA-ICP-MS (Laser Ablation Inductively Coupled Plasma Mass Spectrometry) permite realizar análises in-situ em monocristais de zircão em segmentos entre 20-30 $\mu \mathrm{m}$ (Gehrels et al., 2008). O princípio do método consiste no ataque ao monocristal por um laser a gás que gera partículas por abrasão e as transporta a um espectrômetro de massa acoplado a um plasma, onde é possível realizar a quantificação isotópica. Em rochas plutônicas normalmente são analisados cerca de 20 cristais, dos quais se obtêm idades concordantes que podem representam a idade de cristalização da rocha. Porém, em alguns casos, estas idades podem corresponder à herança isotópica relacionados com as fontes.

A totalidade das análises realizadas para obter as idades de cristalização foram obtidas com um feixe de $30 \mu \mathrm{m}$ diâmetro e uma razão de repetição de $10 \mathrm{~Hz}$ num laser New Wave Nd: YAG UV 213-nm acoplado a um coletor ThermoFinnigan Element 2. Cada dado consistiu em uma análise em branco seguida de 300 varreduras por meio de massas 204, 206, 207, 208, 232, 235 e 238, num tempo de aproximadamente de 35 segundos. O padrão usado foi o Plešovice com uma idade ${ }^{206} \mathrm{U} /{ }^{238} \mathrm{~Pb}$ de $337.13 \pm 0.37$ Ma. (Sláma et al., 2008), e as correções de $\mathrm{Pb}$ foram feitas segundo o método ${ }^{207} \mathrm{~Pb}$ (Williams, 1998). Finalmente, os dados de U-Pb foram reduzidos segundo Chang et al. (2006) e as idades calculadas com Isoplot 4.15 (Ludwig, 2003).

\subsubsection{Isótopos de $\mathrm{Nd}$, $\mathrm{Hf}, \mathrm{Pb}$ e $\mathrm{Sr}$}

A aplicação dos isótopos de $\mathrm{Sr}, \mathrm{Nd}, \mathrm{Pb}$ e $\mathrm{Hf}$ na determinação da composição isotópica inicial das rochas ígneas permite reconstruir a evolução dos magmas desde a fonte até os processos que os modificaram (mistura e/ou contaminação) (Dickin, 1995; Faure \& Mensing, 2005). Com esta análise integrada, é possível reconhecer a participação do manto, da crosta superior e inferior e sua evolução magmática, além da composição da crosta subjacente (Faure \& Mensing, 2005). 
O sistema Sm-Nd deve-se principalmente à habilidade dos elementos terra raras (no caso $\mathrm{Sm}$ e $\mathrm{Nd}$ ) de residirem em vários minerais formadores de rochas, como o plagioclásio, os minerais máficos, allanita, zircão e apatita. O método é baseado na variação da composição isotópica do $\mathrm{Nd}$ pelo decaimento do ${ }^{143} \mathrm{Nd}$ e pelo fracionamento de $\mathrm{Sm}$ e $\mathrm{Nd}$ no processo de diferenciação magmática (De Paolo, 1988). A comparação entre a razão ${ }^{143} \mathrm{Nd} /{ }^{144} \mathrm{Nd}$ com o reservatório CHUR representativo da Terra primitiva, permite definir um indicador petrogenético denominado $\varepsilon_{\mathrm{Nd}}$, o qual, ao ser determinado para a idade de cristalização de uma rocha ígnea, permite definir a contribuição das fontes mantélicas ou crustais na gênese do magma.

Paralelamente, os isótopos de $\mathrm{Hf}$ tem um significado similar aos isótopos de $\mathrm{Nd}$ visto que o sistema Sm-Nd é análogo ao sistema Lu-Hf durante a fusão. Neste caso, a determinação do $\varepsilon_{\mathrm{Hf}}$ baseia-se na comparação entre a razão ${ }^{176} \mathrm{Hf} /{ }^{177} \mathrm{Hf}$ com o reservatório $C H U R$. Os isótopos de Hf são determinados em rocha total ou em zircão, o que tem a vantagem de permitir conhecer a composição isotópica do mesmo ponto onde foi datado o grão. $\mathrm{O}$ zircão que pode ser datado pelo método $\mathrm{U}-\mathrm{Pb}$, igualmente permite incorporar $\mathrm{Hf}$ em sua estrutura cristalina, rejeitando o Lu. Desta forma o Hf inicial que se encontra nestes zircões reflete a composição do magma original antes da cristalização do zircão e, portanto, poderia refletir características específicas do manto do qual o Hf derivou-se ou a contribuição de crosta continental (Kinny \& Maas, 2003; Dickin, 2005).

$\mathrm{O} \mathrm{Pb}$ tem três isótopos radiogênicos que se formam pela desintegração radioativa do $\mathrm{U}$ e Th. As razões isotópicas do $\mathrm{Pb}$ registram os diferentes ambientes onde residiu esse elemento. Os reservatórios de $\mathrm{Pb}$ que podem ser reconhecidos incluem a crosta inferior, o manto e a crosta superior. Esses reservatórios podem misturar-se durante uma orogênese, originando um sinal particular que reflete a idade e os processos de evolução tectônica, o qual pode ser característico de um domínio crustal não exposto (Aitcheson et al., 1995).

A sistemática isotópica do $\mathrm{Sr}$ deve-se a desintegração radioativa do ${ }^{87} \mathrm{Rb}$ em ${ }^{87} \mathrm{Sr}$. A relação isotópica inicial de ${ }^{87} \mathrm{Sr} /{ }^{86} \mathrm{Sr}$, determinada para a idade de cristalização, constitui um indicador petrogenético que permite distinguir nas rochas magmáticas a presença de materiais do manto ou da crosta superior durante a gênese da rocha (fonte) ou adquiridos em processos posteriores (contaminação).

As análises desses isótopos foram realizadas num Multicoletor Thermo-Finnigan Neptune. Os isótopos de $\mathrm{Sr}, \mathrm{Nd}$ e $\mathrm{Hf}$ em rocha total foram obtidos dissolvendo $250 \mathrm{mg}$ de rocha pulverizada com uma mistura 10:1 de $\mathrm{HF}$ e $\mathrm{HNO}_{3}$ a $150{ }^{\circ} \mathrm{C}$ em bombas de Teflon 
seladas durante 7 dias. Depois desde processo foi usada uma mistura dos traçadores ${ }^{149} \mathrm{Sm}-$ ${ }^{150} \mathrm{Nd} \mathrm{e}{ }^{176} \mathrm{Lu}-{ }^{180} \mathrm{Hf}$. Lu-Yb e LREE foram separados em colunas de troca catiônica (AG 50W-X8 resin). A purificação de Hf foi realizada segundo os procedimentos de Münker et al. (2001), Lu foi separado de Yb segundo (Vervoort et al., 2004) e Sm e Nd foram preparados com os procedimentos de Vervoort \& Blichert-Toft (1999).

$\mathrm{O} \mathrm{Nd}$ foi corrigido por fracionamento de massas usando ${ }^{146} \mathrm{Nd} /{ }^{144} \mathrm{Nd}=0,7219$ e normalizado usando um padrão Ames $\mathrm{Nd}$, enquanto o $\mathrm{Sm}$ foi corrigido usando ${ }^{147} \mathrm{Sm} /{ }^{152} \mathrm{Sm}=0,56081$. Sr foi corrigido usando ${ }^{86} \mathrm{Sr} /{ }^{88} \mathrm{Sr}=0,1194$ e normalizado usando o padrão NBS-987. As medições de Lu foram obtidas segundo o método de Vervoort et al. (2004). A reprodutibilidade media com dois desvios padrão é de $\pm 0,000020$ para o padrão Ames Nd e de $\pm 0,000014$ para o padrão $J M C$-475, e para o ${ }^{87} \mathrm{Sr} /{ }^{86} \mathrm{Sr}$ é de $\pm 0,00005$. Os valores de $\varepsilon_{\mathrm{Nd}}$ foram calculados usando valores presentes de ${ }^{143} \mathrm{Nd} /{ }^{144} \mathrm{Nd}=0,512630$ e ${ }^{147} \mathrm{Sm} /{ }^{144} \mathrm{Nd}=0,160$ para o $C H U R$ (Bouvier et al., 2008), e para o $\varepsilon_{\mathrm{Hf}}$ usando valores presentes de ${ }^{176} \mathrm{Hf} /{ }^{177} \mathrm{Hf}=0,282785 \mathrm{e}{ }^{176} \mathrm{Lu} /{ }^{177} \mathrm{Hf}=0,0336$ para o CHUR (Bouvier et al., 2008). Valores isotópicos iniciais foram calculados usando concentrações de $\mathrm{Rb}$ e $\mathrm{Sr}$ do $X R F$ para os isótopos de $\mathrm{Sr}$.

Isótopos de $\mathrm{Pb}$ foram obtidos dissolvendo $250 \mathrm{mg}$ de rocha pulverizada em béquer de $15 \mathrm{ml}$ selados com uma mistura 10:1 de $\mathrm{HF}$ e $\mathrm{HNO}_{3}$ a $120{ }^{\circ} \mathrm{C}$ por 24 horas. $\mathrm{O} \mathrm{Pb}$ foi separado usando uma resina Bio Rad AG1-X8 e medido segundo o método de White et al. (2000). O padrão usado foi NBS-981 com uma concentração de 150 ppb de Pb e 30 ppb de Tl (Galer e Abouchami, 1998).

Para as análises de isótopos de Hf em zircão foi usado um diâmetro de feixe de $40 \mu \mathrm{m}$. O sinal de Hf esteve entre 2 e $6 \mathrm{~V}$, e para melhorar sua sensibilidade, foi usado o gás He com pequenas quantidades de $\mathrm{N}_{2}$ para minimizar a formação de óxidos. Os dados foram obtidos com integrações de 60 segundos. Para obter as idades modelo do manto empobrecido para o $\mathrm{Hf}$, foram usadas as razões ${ }^{176} \mathrm{Hf} /{ }^{177} \mathrm{Hf} \mathrm{e}{ }^{176} \mathrm{Lu} /{ }^{177} \mathrm{Hf}$ para grãos individuais de zircão, e assim determinar as razões ${ }^{176} \mathrm{Hf} /{ }^{177} \mathrm{Hf}$ iniciais para sua idade de cristalização. A curva de evolução de Hf para o manto empobrecido foi calculada com valores presentes de ${ }^{176} \mathrm{Hf} /{ }^{177} \mathrm{Hf}$ $\mathrm{DM}_{(0)}=0,283240$ e ${ }^{176} \mathrm{Lu} /{ }^{177} \mathrm{Hf} \mathrm{DM}_{(0)}=0,03979$ (Vervoort et al., 2015).

\subsubsection{Anisotropia de Suscetibilidade Magnética}

A estrutura de rochas ígneas, e consequentemente os processos de deformação sinmagmática, podem ser investigados através da Anisotropia de Susceptibilidade Magnética 
(ASM; eg. Hrouda, 1982; Borradaile e Henry, 1998). A suscetibilidade magnética é uma propriedade física que relaciona o campo magnético indutor $(\mathrm{H})$ e a magnetização resultante (M). A suscetibilidade magnética (k) é o parâmetro que relaciona $\mathrm{M}$ e $\mathrm{H}$, de maneira que $\mathrm{M}=$ $\mathrm{k} \bullet \mathrm{H}$. A susceptibilidade magnética pode ser entendida com a medida do quão facilmente o material adquire uma magnetização. A anisotropia de susceptibilidade nos materiais rochosos, por sua vez, refere-se à variação direcional da suscetibilidade magnética (e de M). Por outro lado se a suscetibilidade magnética é constante em qualquer ponto da rocha, o material é considerado magneticamente isotrópico.

As rochas ígneas são essencialmente formadas por silicatos, podendo ainda conter óxidos e, mais raramente, sulfetos. Esses minerais apresentam propriedades magnéticas que os distinguem em diamagnéticos, paramagnéticos e ferromagnéticos (s.l.). Os minerais diamagnéticos, como o quartzo e o feldspato, exibem uma suscetibilidade muito fraca e negativa (c. $-10^{-5} \mathrm{SI}$ ). Os paramagnéticos, representados pela mica, anfibólio e piroxênio, possuem suscetibilidade positiva da ordem de $10^{-4}$ a $10^{-3}$ SI. Magnetita, hematita e ilmenita são os principais óxidos das rochas ígneas félsicas (Ishihara, 1977). A magnetita possui suscetibilidade da ordem de $10^{-1}$ a 2 SI e, como a pirrotita, apresenta magnetização espontânea. A hematita e antiferromagnética (sem magnetização espontânea) com suscetibilidade da ordem de $10^{-3}$ SI. A magnetita e a hematita apresentam o fenômeno da remanência, propriedade que é explorada nas investigações paleomagnéticas. Os sulfetos em geral ocorrem como traço nas ígneas intermediárias e félsicas, de forma que contribuição deles à suscetibilidade total é irrelevante.

Em plútons graníticos a magnetita é o principal mineral magnético. Embora presente como mineral acessório, sua forte suscetibilidade faz com que mesmo pequenas quantidades (1 a $3 \%$ da moda nos granitoides) sejam suficientes para que as propriedades magnéticas da rocha (suscetibilidade, remanência, anisotropia) sejam controladas pela magnetita. $\mathrm{Na}$ ausência de magnetita a suscetibilidade magnética vai depender principalmente dos minerais paramagnéticos que, geralmente, estão em volume suficiente para suplantar a contribuição da ilmenita e dos eventuais sulfetos. A ASM nos granitóides com magnetita depende, portanto, da orientação preferencial dos grãos de magnetita. A direção de maior suscetibilidade é denominada de lineação magnética enquanto o plano normal à direção de menor suscetibilidade denominada foliação magnética (eg. Bouchez, 1997). Na ausência de magnetita a anisotropia de suscetibilidade é geralmente fornecida pela orientação preferencial dos minerais paramagnéticos. A distribuição planar da mica normalmente define a foliação 
magnética, enquanto a lineação magnética depende da trama plano-linear de mica e do anfibólio. A magnetita, no entanto, nunca está totalmente ausente do agregado mineral. Muitas vezes ela forma finas inclusões no interior dos silicatos decorrente dos processos de exsolução e/ou alteração hidrotermal que ocorrem nos estágios finais da cristalização magmática. A determinação da orientação preferencial desses grãos pode ser feita através de técnicas que exploram a anisotropia de remanência da magnetita (Jackson, 1991).

Diferentes métodos de investigação vêm demonstrando a boa correlação entre as direções principais de ASM e a trama magmática. Os resultados confirmam o uso da ASM como marcador da direção da foliação e lineação de rochas ígneas intermediárias e félsicas. Essas informações são essenciais na investigação dos processos de alojamento e deformação dos corpos magmáticos e de suas relações com a tectônica regional. 


\title{
Capítulo 2
}

\section{$\mathrm{U}-\mathrm{Pb}$ ages and $\mathrm{Hf}$ isotopes in zircons from Para- Autochthonous Mesozoic terranes in the western margin of Gondwana: implications for the terrane configurations in the Northern Andes ${ }^{1}$}

\begin{abstract}
$\mathrm{U}-\mathrm{Pb} \mathrm{LA}-\mathrm{ICP}-\mathrm{MS}$ ages and $\mathrm{Hf}$ isotopes in zircons were used to constrain the nature of the basement of the Central Cordillera of Colombia. Graphite-quartz-muscovite schists show detrital zircons supplied mostly from Late Jurassic (c. $167 \mathrm{Ma}$ ), Ediacaran (c. $638 \mathrm{Ma}$ ) and Tonian ('Grenvillian'; c. $1.000 \mathrm{Ma}$ ) sources. These marine volcanosedimentary deposits form a $\mathrm{N}$-trending metamorphic belt in fault contact to the east with orthogneisses and amphibolites of the Tierradientro unit. Zircon U-Pb determinations of the Tierradientro rocks, previously interpreted as Grenvillian basement slices, provided crystallization ages between 268 and 240 Ma. Initial Hf data reveal that the Tierradientro unit share isotopic characteristics similar to others Permo-Triassic rocks of the Central Cordillera. In contrast, detrital zircons from the Jurassic metasedimentary rocks suggest that their sources are distinct from the Central Cordillera and nearby Jurassic magmatic rocks. Large xenoliths of the Tierradientro unit within the Ibagué batholith indicate that the granodioritic magma intruded mostly a PermoTriassic basement possibly by exploring the Otú-Pericos fault. The Jurassic metasedimentary belt is correlated further south with a similar sequence in the Ecuadorian Andes.
\end{abstract}

\footnotetext{
${ }^{1}$ Bustamante, C., Archanjo, C., Cardona, A., Bustamante, A., Valencia, V., Vervoort, J. U-Pb ages and Hf isotopes in zircons from Para-Autochthonous Mesozoic terranes in the western margin of Gondwana: implications for the terrane configurations in the Northern Andes. The Journal of Geology (Under review).
} 


\subsection{INTRODUCTION}

Continental margins are modified by the accretion of oceanic and continental terranes during subduction. While the allochthonous origin of oceanic terranes can be recognized by their particular tectonostratigraphic record, identifying continental terranes as transferred from another continental margin (allochthonous) or formed at the same continental margin and transferred by along-strike translation (i.e. para-autochthonous) may be more complicated (Howell, 1995).

The Northern Andean Belt evolved by incorporating continental and oceanic crustal fragments accreted to the margin of South America by strike-slip faults and subduction zones, with the main periods of accretion occurring mostly in the Permo-Triassic, Jurassic and Late Cretaceous (Ramos, 2009). The Permo-Triassic events have been recently characterized as related to continental rifting and anatexis associated to the break-up of Western Pangea (Cochrane et al., 2014a). In the Jurassic the former rifted margin was intruded by continental arc batholiths characterized in their earlier phases by a significant extensional signature (Sarmiento-Rojas et al., 2006; Cochrane et al., 2014b), while the interactions of the Caribbean, Pacific and South American plates in the Cretaceous lead to the bulk compression of the continental margin, accretion of oceanic rocks and lateral migration of crustal blocks along strike-slip faults (Bayona et al., 2006; Pindell and Kennan, 2009; Spikings et al., 2015).

Restrepo and Toussaint (1988) and Restrepo et al. (2011) adopted the tectonostratigraphic terrane model of Howell et al. (1983) to divide the accretionary sequences of the Colombian Andes in four major terranes. They comprise an allochthonous Eastern Andean or Chibcha terrane adjacent to the Precambrian Guiana and Amazonian shields separated by other allochthonous units grouped in the Central and Western Cordilleras (Fig. 2.1). In the Central Cordillera they recognized a Late Paleozoic to Triassic Tahamí terrane bounded to the east by the Otú-Pericos fault. Further west and south, the Tahami and Chibcha terranes are in contact with Cretaceous oceanic terranes (Calima, Cuna) that form the Western Cordillera. The Central and Western Cordilleras are in contact along the CaucaRomeral fault system that includes slices of mediun- to high-pressure metasedimentary and metavolcanic rocks grouped, respectively, in the Arquia and Quebradagrande complexes (Fig. 2.1; Maya and González, 1995; Villagómez et al., 2011). This suture zone has been connected further south with the Peltetec fault zone that forms the western limit of the Permian to Jurassic rocks of the Cordillera Real in Ecuador (Ramos, 2009; Spikings et al., 2015). 


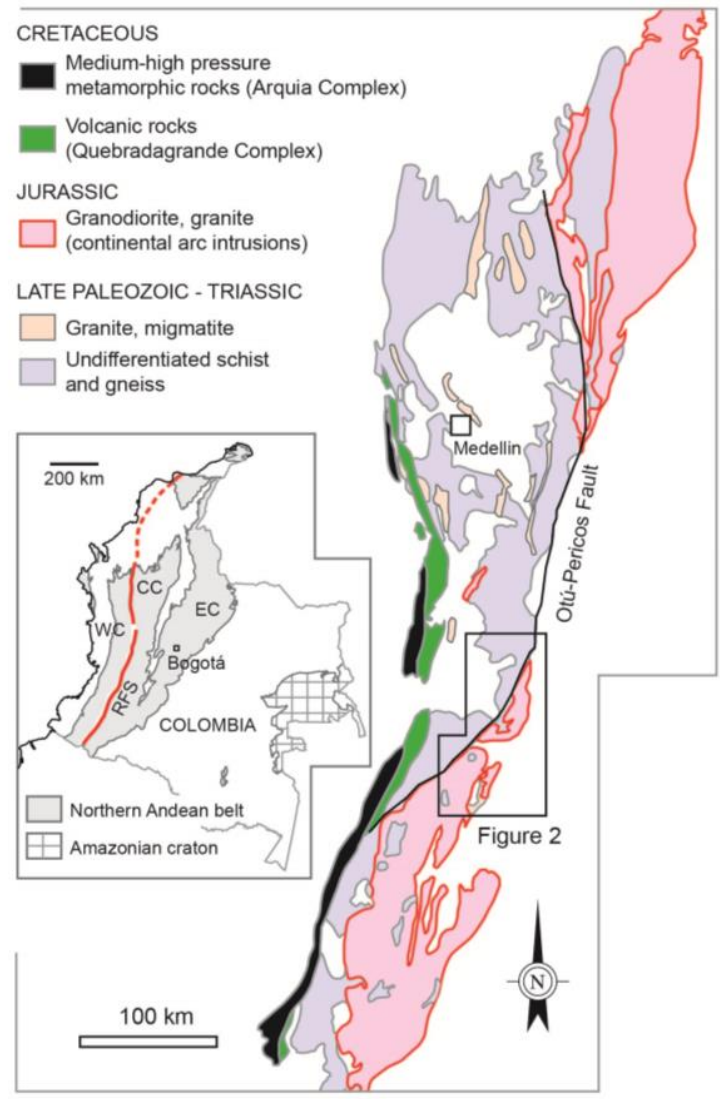

Figure 2.1. Geology of the Central Cordillera (CC) in Colombia and Cordillera Real in Ecuador, showing the distribution of Cretaceous metamorphic and volcanic rocks, Jurassic continental arc intrusions: Abitagua (AB), Ibagué (IB), Mocoa (MB) and Segóvia (SB) batholiths and Permo-Triassic rocks. Inset - Main geological domains of Colombia highlighting the location of the Western (WC) and Eastern (EC) Cordilleras.

The origin of these terranes, and particularly the age of tectono-magmatic events of the Tahami and Chibcha terranes have been intensely debated (Vinasco et al., 2006; CardonaMolina et al., 2006; Restrepo et al., 2011; Martens et al., 2014; Blanco-Quintero et al., 2014; Spikings et al., 2015). According to Restrepo and Toussaint (1988) and Toussaint and Restrepo (1989), one of the major distinctions between Tahami and Chibcha terranes account for Permian metamorphic events just recorded in the former, and the Jurassic magmatism and sedimentation that would be found only in the Chibcha terrane (Restrepo et al., 2011). Jurassic metasedimentary rocks, however, have been identified in the Cordillera Real of Ecuador (Salado terrane) next to the Peltetec fault (Litherland et al., 1994; Spikings et al., 2015), although no Jurassic metasedimentary sequences have been recognized until now in the Central Cordillera of Colombia. Furthermore, Permo-Triassic gneisses have been recently identified to the east of the Otú-Pericos fault (Villagómez at al., 2011; Cochrane et al., 2014a), and a Jurassic metamorphism on rocks attributed to the Permian Cajamarca Complex 
has been identified to the west of the Ibagué batholith (Blanco-Quintero et al., 2014). These recent results therefore challenge the identification of the Otú-Pericos fault as a terranerelated boundary and consequently the definition of Tahami and Chibcha as allochthonous terranes based on the criteria outlined by Restrepo and Toussaint (1988).

Our study examines the geological evolution of units on both sides of the Otú-Pericos fault near the northern termination of the Ibagué batholith (Tolima Department). We present new zircon U-Pb LA-ICP-MS and Hf isotope data for orthogneisses and amphibolites from a geological unit known as Tierradentro sequence, and detrital zircons of pelitic schist from the Tahamí terrane. The Tierradentro sequence has been mapped as slices of Grenvillian rocks (ca. $1 \mathrm{Ga}$ ) that bound the Chibcha Terrane (Fig. 2.2). According to the geological map of Colombia (Gómez-Tapias et al., 2015), such gneisses and amphibolites also form kilometresize enclaves interpreted as roof-pendants within the Ibagué batholith. In contrast, the pelitic schists have been correlated to the Cajamarca Complex. Our data show that the Tierradentro gneisses and amphibolites are not 'Grenvillian rocks' while the metapelites record a peak detrital zircon population at ca. 167 Ma. These results suggest that the Otú-Pericos fault may represent a more complicated structure, which seems to limit distinct sequences that were separated from the continental margin by major extensional faults. The new results also evidence the existence of Jurassic metasedimentary deposits in the Central Cordillera undocumented until now and the use of Hf isotopic signatures to discriminate the origin of contemporaneous magmatic rocks. 


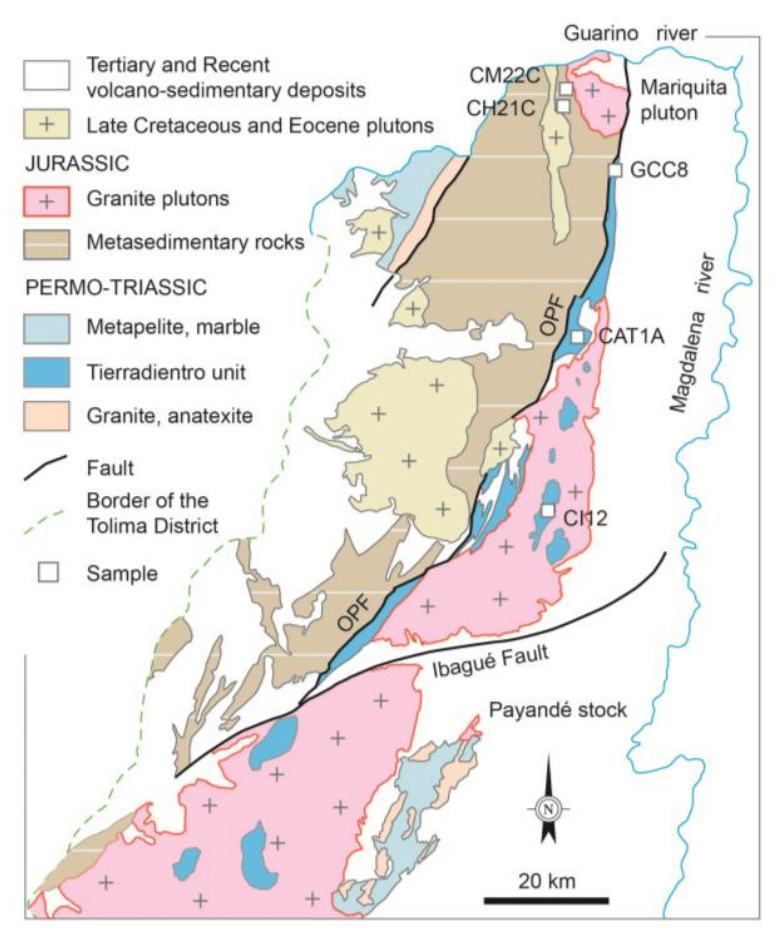

Figure 2.2. Detailed geological map of the study area, showing the samples distribution (squares) and the relations between the studied units.

\subsection{GEOLOGICAL SETTING}

The Andean Chain in Colombia is composed by three mountain ranges - the Western, Central and Eastern Cordilleras - separated from Amazonia craton by an extensive foreland basin (Fig. 2.1, inset). The Western Cordillera comprises allochthonous oceanic rocks that accreted to the continental margin since the Late Cretaceous (Kerr et al., 1997; Villagómez et al., 2011). These sequences were separated in the Calima and Cuna terranes, the later accreted to the continent in the Miocene (Restrepo et al., 2011). The Eastern Cordillera comprises a basement composed by Precambrian gneisses, granulites and amphibolites, Ordovician to Silurian granitoids that are covered by transitional siliciclastic and carbonate Paleozoic deposits (Kroonenberg, 1982; Restrepo-Pace et al., 1997; Cordani et al., 2005; OrdóñezCarmona et al., 2006; Cardona-Molina et al., 2006; Van der Lelij et al., 2015). A major Late Carboniferous tectonic event has been discriminated based on a major Pennsylvanian hiatus and the existence of some angular discordance with the Permian (Toussaint, 1995).

They form the Chibcha terrane which is limited to the east by the Guaicáramo fault. Isolated Proterozoic inliers to the southeast of the Guaicáramo fault define the Andaquí terrane which is also considered as a prolongation of the continental margin (Ibañez-Mejia et al., 2011). In turn, the Central Cordillera consists of Permian to Triassic I-type magmatic 
rocks, migmatites and amphibolites (Vinasco et al., 2006; Cochrane et al., 2014a; Spikings et al., 2015) grouped in the Cajamarca Complex, with an Ordovician protolith (Martens et al., 2104). The Permo-Triassic units of the Central Cordillera have been correlated in Central America with the Mexican terranes which were formed in a continental arc (Torres et al., 1999; Dickinson and Lawton, 2001). Further south in Ecuador, they were correlated with Triassic S-type granitoids and metamorphic rocks of the Loja Terrane in the Cordillera Real (Noble et al., 1997; Riel et al., 2013; Spikings et al., 2015).

The high- to medium grade rocks of the Cajamarca Complex intruded by Triassic Stype granitoids form the basement sequence of the Central Cordillera, with the age of its metamorphism varying from Mid- to Late Triassic (ca. 240-230 Ma; Vinasco et al., 2006; Restrepo et al., 2011; Cochrane et al., 2014a).

In the Ibagué area to the south of the Central Cordillera (Fig. 2.2) the metasedimentary rocks included in the Cajamarca complex are intruded by Jurassic to Cretaceous plutons (i.e. Ibagué batholith and Mariquita stock) and Eocene magmatic rocks. According to BlancoQuintero et al. (2014), the peak metamorphic conditions determined in garnet-biotite schists reached 550-580 ${ }^{\circ} \mathrm{C}$ and $8 \mathrm{kbar}$ while ${ }^{40} \mathrm{Ar} /{ }^{39} \mathrm{Ar}$ determinations in amphibole and phengite between 146 and $158 \mathrm{Ma}$ defined the age of the peak metamorphic conditions. These Late Jurassic ages contrasted with previous Triassic metamorphism of the Cajamarca Complex, which lead Blanco-Quintero et al. (2014) to propose a distinct Late Jurassic collisionaccretion event in the Central Cordillera.

The Tierradentro gneisses and amphibolites are exposed in the limit between the Tahami and Chibcha terranes and define the trace of the Otú-Pericos fault (Restrepo et al., 2011). These poorly studied rocks have been correlated with the Proterozoic basement of the eastern flank of the Central Cordillera (Kroonenberg, 1982; Restrepo-Pace et al., 1997) due to lithological similarities (Marquinez and Núñez, 1998; Núñez, 2001) and a K-Ar age of $1360 \pm$ $270 \mathrm{Ma}$ (Vesga and Barrero, 1978), and therefore have been included as part of the Chibcha Terrane. The Tierradientro unit is composed by discontinuous lenses of ortho- and paragneisses, amphibolites, minor granulites and marbles that form both the host-rocks and enclaves of the northern part of the Ibagué batholith (Fig. 2.2). The batholith shows zircon U$\mathrm{Pb}$ ages ranging from 142 to $170 \mathrm{Ma}$ (Villagómez et al., 2011; Leal-Mejía, 2011; Bustamante et al., 2016). The wall-rocks to the east of the batholith include Triassic limestones intruded by the Payandé stock (ca. 165 Ma, Bustamante et al., 2016). Anatexites close to the Payandé 
stock provided zircon $\mathrm{U}-\mathrm{Pb}$ ages of ca. $230 \mathrm{Ma}$, which is the first Triassic ages reported to the east of the Otú-Pericos fault (Cochrane et al., 2014a).

\subsection{ANALITICAL METHODS}

\subsubsection{LA-ICP-MS U-Pb Geochronology in zircon}

LA-ICP-MS U-Pb analyses were acquired in a New Wave Nd: YAG UV 213-nm laser coupled to a ThermoFinnigan Element 2 single collector, double-focusing, magnetic sector ICP-MS at the Washington State University. Laser spot size was $30 \mu \mathrm{m}$ and repetition rate 10 Hz. He and Ar carrier gases delivered the sample aerosol to the plasma. Each analysis consisted of a short blank analysis followed by 300 sweeps in approximately 35 seconds, through masses 204, 206, 207, 208, 232, 235, and 238. A compilation of ages obtained in this study is presented in Tables 2.1 and 2.2.

Time-independent fractionation was corrected by normalizing $\mathrm{U}-\mathrm{Pb}$ and $\mathrm{Pb} / \mathrm{Pb}$ ratios of the unknowns to the zircon standards (Chang et al., 2006). For this study we used the zircon standard Plešovice, with a ${ }^{206} \mathrm{U} /{ }^{238} \mathrm{~Pb}$ age of $337.13 \pm 0.37 \mathrm{Ma}$ (Sláma et al., 2008) with the common $\mathrm{Pb}$ corrections using the ${ }^{207} \mathrm{~Pb}$ method (Williams, 1998). Uranium-lead data were reduced following Chang et al. (2006) and ages were calculated and plotted using Isoplot v. 4.15 of Ludwig (2003). The final crystallization ages that we report are Tuff Zircon ages.

\subsubsection{Hf isotopes in zircon}

Hf isotope geochemistry was investigated in 3 samples (Table 2.3) at the Geoanalytical Lab at Washington State University, in a ThermoFinnigan Neptune ${ }^{\mathrm{TM}}$ MC-ICPMS with 9 faraday collectors interfaced with a New Wave ${ }^{\mathrm{TM}} 213 \mathrm{~nm}$ UP Nd-YAG laser. Pulse rate of the laser was $10 \mathrm{~Hz}$, fluence was of $10-12 \mathrm{~J} / \mathrm{cm}^{2}$ and laser spot size was $40 \mu \mathrm{m}$. Purified He plus small quantities of $\mathrm{N}_{2}$ gases were used as carrier gases to minimize oxide formation and increase Hf sensitivity.

Analytical procedures and data treatment are detailed in Vervoort et al. (2004) and DuFrane et al. (2007). ${ }^{176} \mathrm{Hf} /{ }^{177} \mathrm{Hf}$ and ${ }^{176} \mathrm{Lu} /{ }^{177} \mathrm{Hf}$ were used to calculate Hf-depleted mantle model ages $\left(\mathrm{Hf}_{\mathrm{TDM}}\right)$ for the individual zircon samples, in order to determine their initial ${ }^{176} \mathrm{Hf} /{ }^{177} \mathrm{Hf}$ ratios at their crystallization ages. Projection back from zircon crystallization was calculated using a present value of 0.0150 for the estimated ${ }^{176} \mathrm{Lu} /{ }^{177} \mathrm{Hf}$ of continental crust (Vervoort and Patchett, 1996; Goodge and Vervoort, 2006). Present-day depleted mantle 
values of ${ }^{176} \mathrm{Hf} /{ }^{177} \mathrm{Hf} \mathrm{DM}_{(0)}=0.283240$ and ${ }^{176} \mathrm{Lu} /{ }^{177} \mathrm{Hf} \mathrm{DM}_{(0)}=0.03979$ (Vervoort et al., 2015) were used to calculate the depleted mantle Hf evolution curve.

\subsection{RESULTS}

\subsubsection{Tierradentro unit}

The samples (see location in Fig. 2.1) of the Tierradentro unit comprise an orthogneiss (GCC8) and an amphibolite (CAT1A) exposed in faulted contact with micaschists, and an hornblende gneiss (CI12) that crops out as a roof pendant within the Ibagué batholith.

The hornblende gneiss (CI12) that forms a roof pendant within the Ibagué batholith is composed by plagioclase $\mathrm{An}_{12}(39 \%)$, orthoclase (28\%), quartz (22\%), and hornblende (11\%). The secondary phases are included as products of saussuritization and sericitization processes at the core and rims respectively in plagioclase grains. Prenhite occurs in veins cutting the sample and chlorite as a pseudomorphic phase after biotite. Accessory phases include zircon, apatite, titanite and opaque minerals. The gneiss shows a foliation defined by recrystallized quartz ribbons surrounded by hornblende and plagioclase. Quartz has sutured boundaries and undulatory extinction. The amphibole also appears as porphyroblasts with minor portions replaced by chlorite and calcite, mainly at the cleavage planes. Using mineralogical data it is possible to suggest that the sample reached the amphibolite facies and the protolith correspond to a quartz-feldspatic rock.

Zircons of the hornblende gneiss range from 70 to $300 \mu \mathrm{m}$ in length. They are mainly subhedral normally with subrounded to rounded terminations. CL images record a faint oscillatory zoning close to the margin as well as in the center of some zircons (Fig. 2.3). Th/U ratios of the grain population vary from 0.21 to 1.04 (Table 2.1) suggesting they are magmatic zircons (Rubatto, 2002).

$\mathrm{U}-\mathrm{Pb}$ analyses were performed in 79 zircons. After removing from the calculations two younger ages (c. $188 \mathrm{Ma}$ ) apparently with no geological significance and two older ages (280 and $287 \mathrm{Ma}$ ) possibly corresponding the inheritance, the analysis provided a ${ }^{206} \mathrm{~Pb} /{ }^{238} \mathrm{U}$ mean age of $268.2+1.9 /-0.5 \mathrm{Ma}$ (Fig. 2.4). There is no significant age difference between the $\mathrm{U}-\mathrm{Pb}$ ages in cores and their respective rims in the zircons of the hornblende gneiss (see analytical results in Table 2.1). These results indicate that the zircons record the age of the igneous protolith and that they were not affected by late metamorphic events as suggested by the absence of overgrowths observed on CL images. 

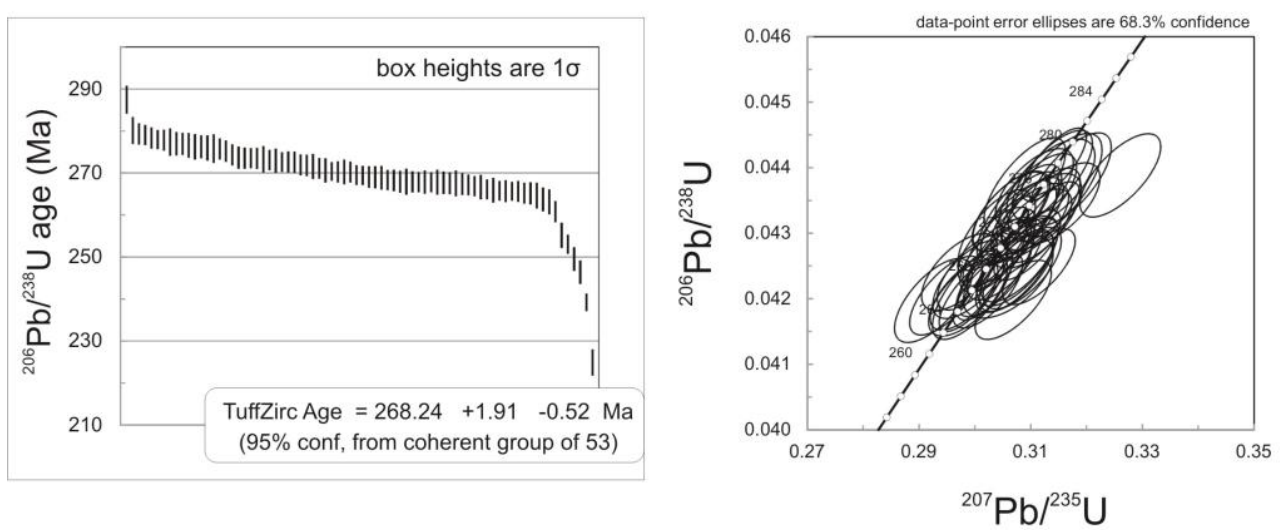

Figure 2.3. $\mathrm{U}-\mathrm{Pb}$ ages and Concordia diagram obtained from zircon rims representing the crystallization age of the CI12 sample (Quartz-feldspathic-gneiss). Scale bar on CL image is $100 \mu \mathrm{m}$.

The amphibolite (CAT1A) is made up of hornblende (61\%), plagioclase $\mathrm{An}_{36}(27 \%)$ and quartz (12\%). Secondary minerals include mainly muscovite as product of retrograde metamorphism of plagioclase and chlorite replacing hornblende. Normal zoning of plagioclase is detected by the saussuritization at the core and sericitization in the rims. Texturally the sample exhibit a nematoblastic texture defined by the hornblende crystals orientation, but several mylonitic textures are observed in recrystallized and mortar quartz and deformed plagioclase twins systems. Through the mineralogical analyses is determined the amphibolite facies and an intermediate protolith for the sample.

Zircons of this amphibolite sample are anhedral to subhedral, usually with rounded terminations but a few prismatic grains. Their sizes range from 60 to $250 \mu \mathrm{m}$ in length (Fig. 2.4). CL images shows zircons usually with dark, U-rich cores rimmed by lighter rims (Fig. 2.3). A few grains, however, display light U-poor cores surrounded by darker rims. However, no significant differences were found in $\mathrm{Th} / \mathrm{U}$ ratios and ages after analyzing cores and rims of the zircons. 

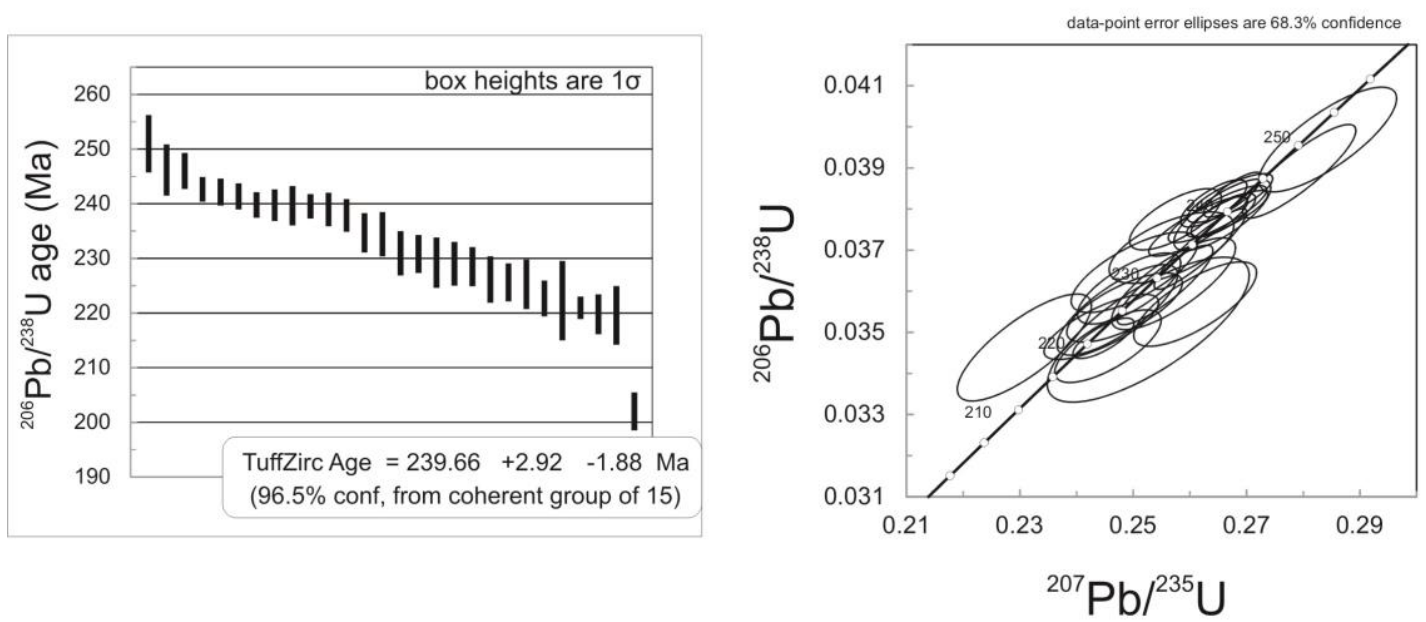

Figure 2.4. U-Pb ages and Concordia diagram obtained zircon rims representing the metamorphic age of the CAT1A sample (amphibolite). Scale bar on CL image is $100 \mu \mathrm{m}$.

Thirty zircons of the amphibolite (CAT1A) provided a ${ }^{206} \mathrm{~Pb} /{ }^{238} \mathrm{U}$ mean age of 239.7 +2.9/-1.9 Ma (Fig. 2.5). The age calculation was obtained after discarding two zircons with older ages (ca. $330 \mathrm{Ma}$ ), possibly corresponding to inheritance, and one zircon with a younger age attributed to $\mathrm{Pb}$ loss. Th/U ratios are relatively low, ranging from 0.1 to 0.44 with a few grains with even lower values. The mean age is interpreted as the magmatic crystallization of the zircon which show Th/U ratios which are systematically higher than 0.1 (Rubatto, 2002).
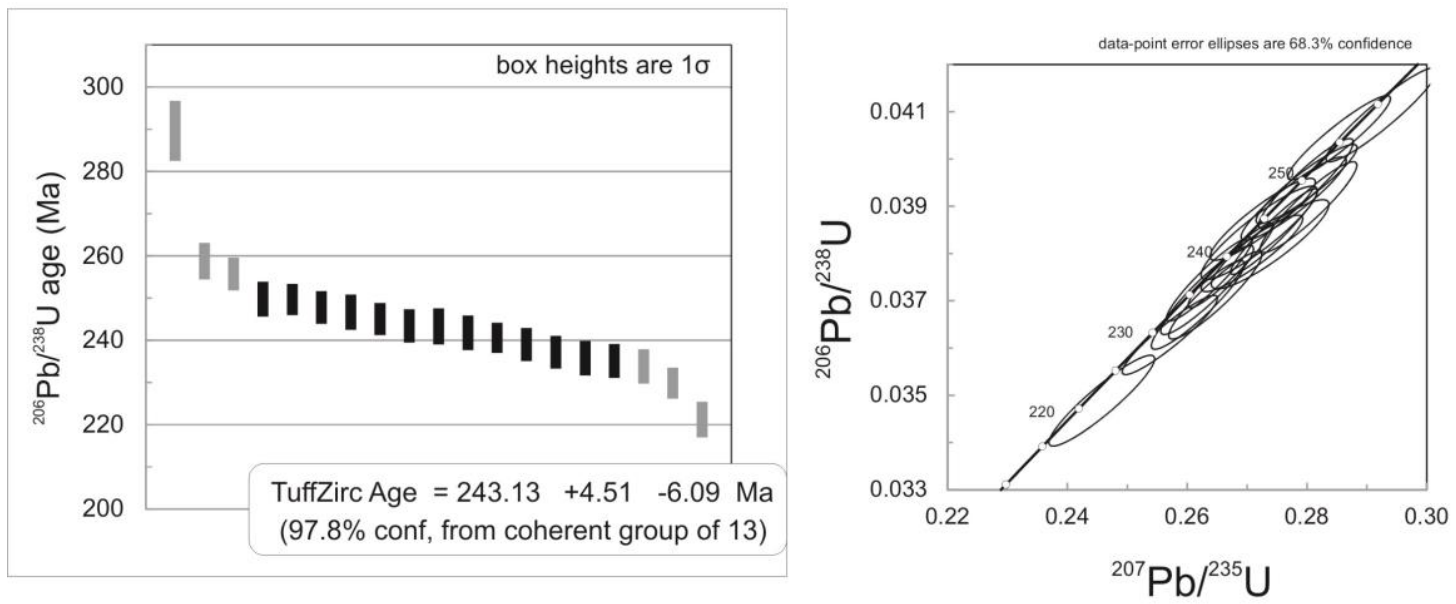

Figure 2.5. U-Pb zircon ages and Concordia diagram obtained from sample GCC8 (augen granodiorite) whose age is in the same range of sample CAT1A. 
A mylonitized augen granodiorite (GCC8) was described in hand sample. It is composed by plagioclase (50\%), quartz (20\%), K-feldspar (15\%), biotite (10\%) and muscovite $(5 \%)$. The latter associated to the main deformational fabric, whereas the $\mathrm{K}$ feldspar is found as the augen phenocryst.

Nineteen zircons of the ortho-gneiss (GCC8) yielded a ${ }^{206} \mathrm{~Pb} /{ }^{238} \mathrm{U}$ mean crystallization age of 243.1 +2.5/-6.1 Ma (Fig. 2.5). Two zircons with younger ages (221 and $230 \mathrm{Ma}$ ) and one zircon possibly corresponding to a xenocryst (c. $290 \mathrm{Ma}$ ) were removed from the mean age calculation.

\subsubsection{Detrital zircons of the Tahamí terrane}

Two schist samples were obtained from the Tahamí Terrane (see locations on Fig. 2.2). They possess intrusive relationships with the early cretaceous Mariquita Stock (CM22C) and the Eocene Hatillo Stock (CH21C). However, zircons were only obtained from sample $\mathrm{CH} 21 \mathrm{C}$ and sample $\mathrm{CM} 22 \mathrm{C}$ is described for reference.

Sample $\mathrm{CH} 21 \mathrm{C}$ is graphite-quartz-muscovite schists. It is composed by muscovite $(44 \%)$, quartz (34\%), graphite (15\%), biotite (3\%), plagioclase (2\%), and andalusite (2\%). Accessories include apatite, zircon and opaque minerals. Tourmaline is found as a trace mineral. Schistosity is defined by oriented micas with recrystallized quartz, which form a granolepidoblastic texture. Decussate texture defined by biotite indicates a possible superimposed contact metamorphism event. Epidote and muscovite appears locally as an alteration product. With the mineral association of this sample it is possible to propose the greenschist facies and pelite sediment as the protolith for the analyzed sample.

Eighty seven zircons were extracted from the micaschist (Table 2.2) since the amphibole schist did not provide any zircon. The grains exhibit oscillatory zoning and have mainly subrounded to rounded terminations. Sizes range from 40 to $100 \mu \mathrm{m}$ although a few crystals can reach $\sim 170 \mu \mathrm{m}$ in length (Fig. 2.3). The analysis come from the sectors with oscillatory zoning usually next to the zircon margin; some analysis, however, were obtained in the cores to check the possible multistage evolution of the zircons.

$\mathrm{Th} / \mathrm{U}$ ratios of the grain population range from 0.13 to 2.07 , which are typical of magmatic zircons (Rubatto, 2002). Three zircons with Proterozoic ages have Th/U ratios of $\sim 0.04$ which suggest a metamorphic origin. The major zircon population, however, shows Middle Jurassic ( $167 \mathrm{Ma})$ and Ediacaran $(\sim 638 \mathrm{Ma})$ ages with the youngest detrital zircon set at $162.5 \pm 1.8 \mathrm{Ma}$. A few zircons display Paleozoic (Ordovician and Carboniferous), 
Mesoproterozoic (Grenvillian) and Paleoproterozoic (Siderian and Statherian) ages (Fig. 2.6). Permo-Triassic zircons are represented, by one grain showing Triassic ( 245 Ma) and other one grain with Permian ( 281 Ma) concordant ages.

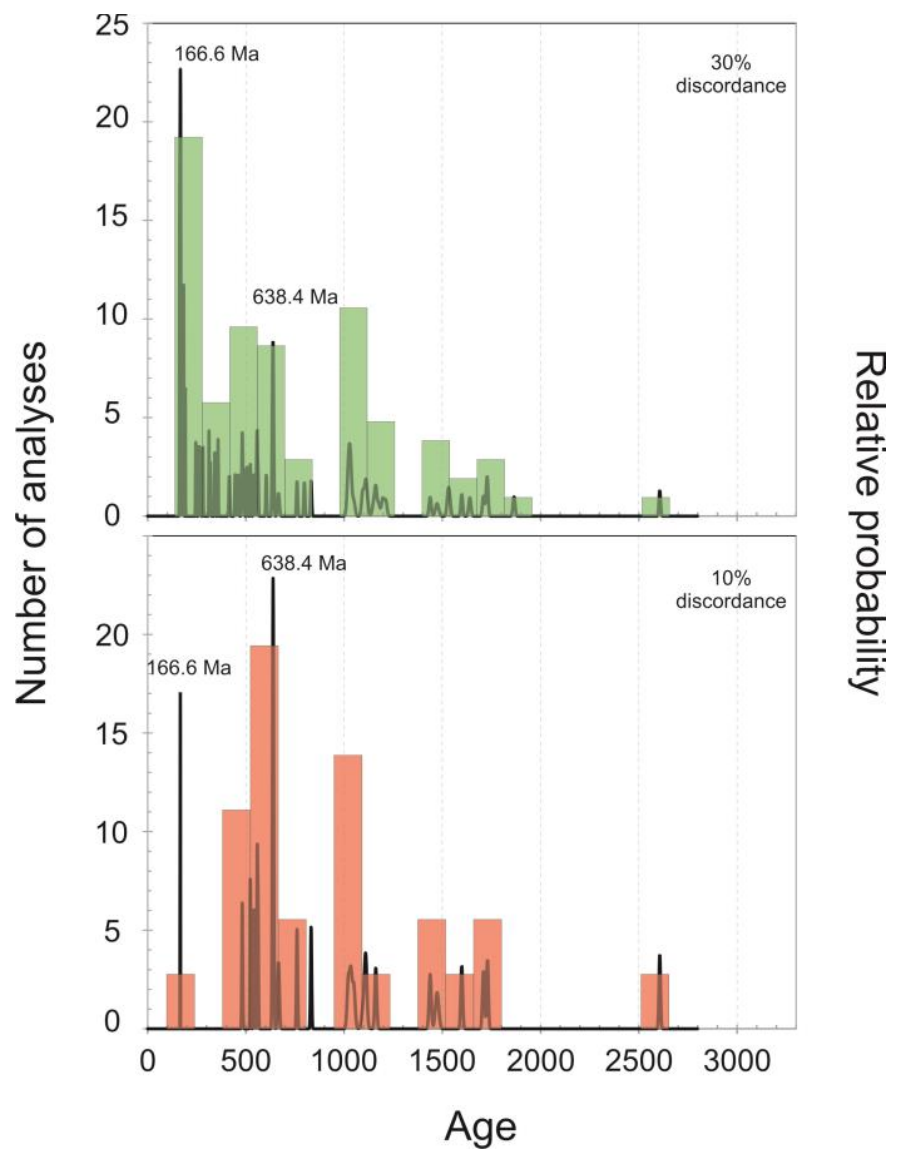

Figure 2.6. U-Pb detrital zircon results from the quartz-muscovite schist $(\mathrm{CH} 21 \mathrm{C})$, showing less than $30 \%$ discordance and less than $10 \%$ discordance for comparison.

Sample CM22C is a plagioclase-hornblende schists composed by hornblende (63\%), plagioclase $\mathrm{An}_{32}(25 \%)$, and quartz (10\%). Clinozoisite veins crosscut the foliation, which is defined by alternating bands of recrystallized plagioclase-quartz and oriented hornblende. Several clinozoisite grains are also accompanying the foliation of the rock. Opaque minerals (2\%) as ilmenite and magnetite are observed as disseminated phases in the sample. Fine-grain muscovite is also observed as a replacement product of plagioclase. These alternating bands, in turn, define a granonematoblastic texture in the rock. The mineralogical composition suggests that the sample was submitted to amphibolite facies and the protolith was an intermediate rock. 


\subsection{Hf ISOTOPE GEOCHEMISTRY}

\subsubsection{Tierradentro unit}

Hf isotopes were measured in the rims of eight zircons from samples CI12 (hornblende gneiss) and CAT1A (amphibolite). Contrasting values were obtained on these samples. Initial $\varepsilon_{\mathrm{Hf}}$ values range from -0.1 to -2.5 for the ortho-gneiss, which suggest a crustal source for the protolith (Fig. 2.7). The amphibolite yielded initial $\varepsilon_{\mathrm{Hf}}$ values ranging from +9.2 to +10.9 indicating a mantle source for the protolith with values close to the depleted mantle curve (Fig. 2.7). Similar values were obtained by Cochrane et al. (2014a) in other Permo-Triassic localities of the Central Cordillera (Fig. 2.7).
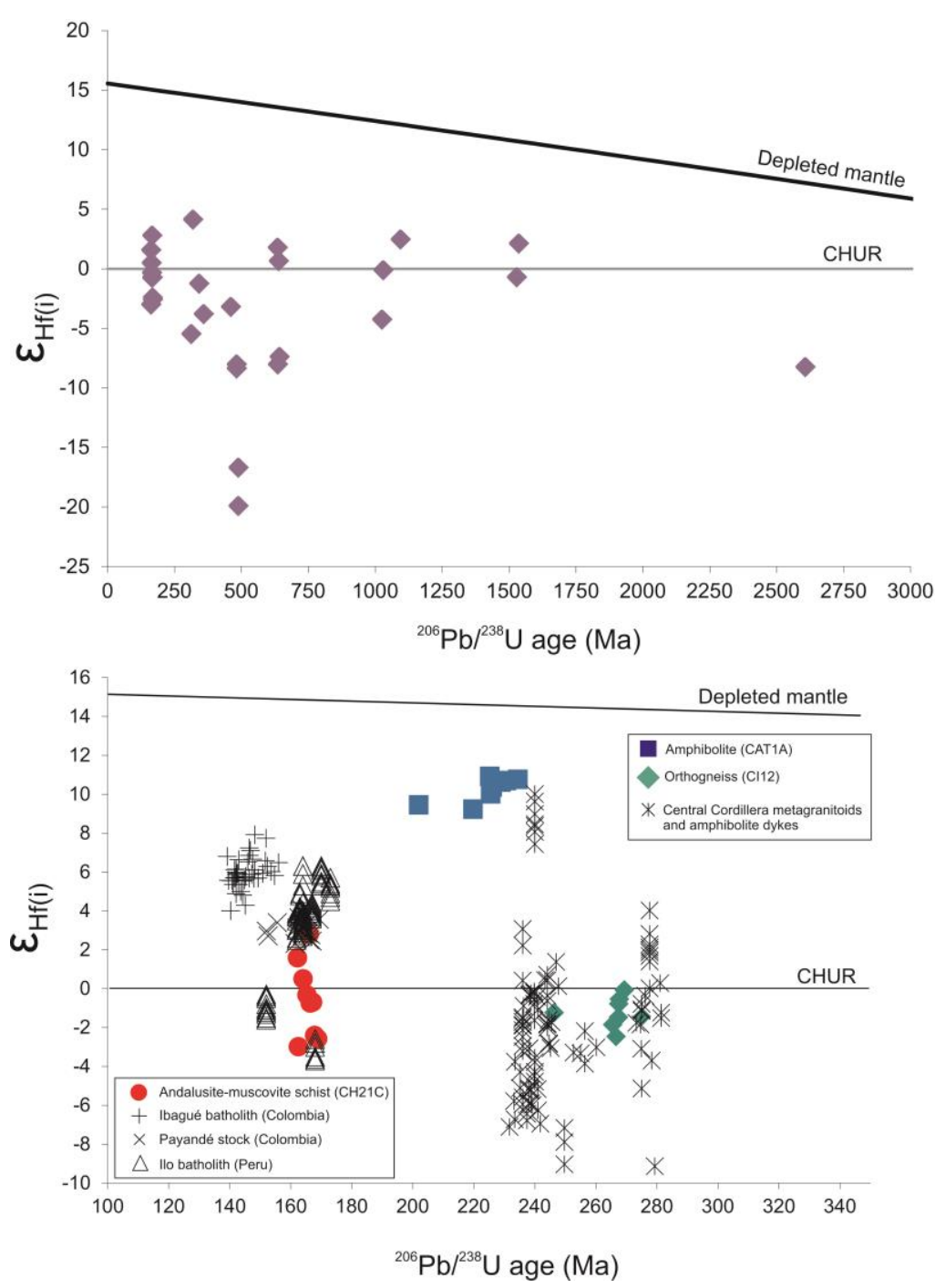

Figure 2.7. Upper: Distribution of the whole $\varepsilon_{\mathrm{Hf(i)}}$ obtained for the Cajamarca Complex. Lower: Initial $\varepsilon_{\mathrm{Hf}}$ vs. ${ }^{206} \mathrm{~Pb} /{ }^{238} \mathrm{U}$ age diagram. Squares represents zircons from sample CAT1A (amphibolite) with a strong juvenile signature as opposite to the zircons from the sample CI12 (hornblende gneiss) represented by triangles, which reflects the involvement of crustal sources for this rock. Circles are from detrital zircons of the Tahamí terrane. See the comparison with published data from other Middle Jurassic plutons of the Central and Northern Andes [Ilo batholith: Boekhout et al. (2012). Payandé and Ibagué plutons: Bustamante et al. (2016); Cochrane et al. (2014b)]. 


\subsubsection{Graphite-quartz-muscovite schist}

We analyzed twenty-eight zircons covering the $\mathrm{U}-\mathrm{Pb}$ age spectra of the micaschist, but with a special emphasis on the Jurassic zircons. Hf isotopes from the older zircons usually show a strong involvement of an old crustal component (Fig. 2.7). $\varepsilon_{\mathrm{Hf}(\mathrm{i})}$ for the oldest zircons is -8.2 and -0.7 (Siderian and Statherian respectively). For the Grenvillian zircons, $\varepsilon_{\mathrm{Hf}(\mathrm{i})}$ is -0.3 and -4.3 with a crystals showing a juvenile value of +2.5 . Two Ediacaran zircons have $\varepsilon_{\mathrm{Hf}(\mathrm{i})}$ of -7.4 and -8.0 , and other two yielded slightly juvenile values of +0.7 and +1.8 . Paleozoic (Ordovician and Carboniferous) zircons show values from -19.9 to -1.2. $\varepsilon_{\mathrm{Hf}(\mathrm{i})}$ values of nine Jurassic zircons (Fig. 2.7) provided three zircons with positive values ranging from +0.5 to +2.8 , and six zircon yielded values between -0.3 and -3.0 (Table 2.3; Fig. 2.7).

\subsection{DISCUSSION}

$\mathrm{U}-\mathrm{Pb}$ zircon ages indicate that the Tierradentro orthogneiss and amphibolite were formed in the Permo-Triassic (ca. 268-239 Ma). The orthogneiss exposed as a roof pendant within the Ibagué batholith provided initial $\varepsilon_{\mathrm{Hf}}$ from -0.1 to -2.5 and show a component that is more characteristic of an older radiogenic continental crust input. The amphibolite, in contrast, provided initial $\varepsilon_{\mathrm{Hf}}$ from +9.2 to +10.9 to indicate a juvenile mantle derived source. These data are similar to those obtained in different regions of the basement rocks of the Central Cordillera and Ecuador that are attributed to a geodynamic setting that includes Permo-Triassic rifting with associated bimodal magmatism related to continental break-up succeeded by subduction of the proto-Pacific (Cardona et al., 2010; Villagómez et al., 2011; Cochrane et al., 2014a). Our results therefore show that not all the Tierradentro rocks are Grenvillian in age as previously considered, and that accordingly the walls of the Jurassic Ibagué batholith were formed in the Permo-Triassic. The distribution of Precambrian rocks in the Central Cordillera therefore also appears to be overstated (Kroonenberg, 1982; RestrepoPace et al., 1997). Although, Mesoproterozoic sequences close to the northern border of the Jurassic Segovia batholith has been documented in the San Lucas Range and the Las Minas Serranía in the Upper Magdalena Valley (Restrepo-Pace et al., 1997; Cuadros et al., 2014).

Permo-Triassic gneisses, migmatites, amphibolites and metasedimentary rocks have been considered as a major element of the Cajamarca Complex and the Tahamí Terrane (Restrepo and Toussaint, 1988; Vinasco et al., 2006; Restrepo et al., 2011; Martens at al., 2014). Zircon crystallization age of S-type granitoids and ${ }^{40} \mathrm{Ar} /{ }^{39} \mathrm{Ar}$ amphibole cooling ages indicate that the high grade metamorphism of the northern part of the Cajamarca Complex 
occurred in the Mid- to Late Triassic (Vinasco et al., 2006; Cochrane et al., 2014a). Their continuity to the south of the Central Cordillera, however, has been previously inferred based on few geochronological constraints and lithological correlations.

In the Tolima Department, the Otú-Pericos fault marks the contact of the Tierradientro gneisses and amphibolites with pelitic schists deposited in the Jurassic. Further south the Tierradientro unit pinches out and the Otú-Pericos fault defines the western contact of the Ibagué batholith. We can envisage that the Ibagué batholith intruded mostly Permo-Triassic orthogneisses and amphibolites. The granitic magma would have moved upward to incorporate, during the ascent, xenoliths of variable sizes of the Tierradientro unit. Smaller Jurassic-Early Cretaceous plutons, such as the Payandé stock and the Mariquita pluton, intruded respectively the Late Triassic calcareous rocks located east of the Otú-Pericos fault and amphibole schists (sample CH21C) (Fig. 2.2). Permo-Triassic rocks found on both sides of the Otú-Pericos fault agree with recent data reported in the Central Cordillera that put into question the reliability of the terrane discrimination analysis that used contrasting Mesozoic basement history as the major criteria for the terrane model (Villagómez et al., 2011; Cochrane et al., 2014a; Blanco-Quintero et al., 2014; Spikings et al., 2015). However, BlancoQuintero et al. (2014) have identified a Jurassic (158-147 Ma) metamorphism based on ${ }^{40} \mathrm{Ar} /{ }^{39} \mathrm{Ar}$ plateau ages in mica and amphiboles from schists and amphibolites, and which contrast with the Triassic metamorphism of the Cajamarca Complex defined in the northern part of the Central Cordillera.

Our results confirm the presence of Mesozoic record in the metamorphic rocks of the Central Cordillera formerly considered as the Cajamarca Complex. The new data suggest the existence of a Jurassic depositional basin floored by Permo-Triassic rocks that was feed by detrital zircons supplied in part by the erosion of Jurassic sources, highlighting the importance of the Jurassic events in the assembly of the Central Cordillera. The Jurassic metavolcanosedimentary belt in the Tolima Department including the area defined by BlancoQuintero et al. (2014) forms an N-trending elongated sequence in fault-contact with PermoTriassic rocks (Fig. 2.2). This fault system corresponds to the Otú-Pericos that was used to define the eastern limit of the Tahami terrane.

A critical aspect of the detrital zircon results from the Jurassic detrital zircons found in the metasedimentary rocks of the Cajamarca Complex is their source area. Although Middle to Late Jurassic magmatic rocks are common along the Ecuadorian and Colombian Andean margins (Cochrane et al., 2014b; Spikings et al., 2015; Bustamante et al., 2016), initial Hf 
isotopic signatures in zircons from the mica schist are more radiogenic and differed from those recognized in the Jurassic magmatic belts that characterized the Northern Andes east of the Cajamarca Complex (Fig. 2.7). Their higher radiogenic values show some resemblance with magmatic rocks farther south such as the Ilo batholith in Peru which is emplaced in Precambrian crust (Boekhout et al., 2012). Both the presence of Triassic and Jurassic magmatic record questioned the simple separation of the Tahamí and Chibcha terranes with an age criteria. However the radiogenic Hf isotopic signature found in the schist sample from the Cajamarca Complex suggest that the Jurassic source areas for the studied schist differed from the eastern Jurassic magmatic rocks associated to the Chibcha Terrane.

When the Jurassic tectonostratigraphic record is compared, a major difference also arises between the Chibcha and Tahamí terranes. Whereas the former records the growth of an arc setting (Bustamante et al., 2016), the later experienced a metamorphic event associated with a collisional setting (Blanco-Quintero et al., 2014) in a geothermal gradient which do not match with the high heat flux expected in an arc setting. Such contrasting tectonic scenarios separated by the Otú-Pericos fault suggest that their tectonic history cannot be explained by lateral variation of tectonic style (Howell, 1995), and suggest a contrasting tectonic evolution. After such tectonostratigraphic constraints we therefore suggest a series of different tectonic scenarios for the Triassic to Jurassic tectonic evolution of both terranes.

Triassic rocks from the Chibcha and Tahamí terranes are similar in character and age, and therefore suggest that they experience a common sin-tectonic extensional evolution associated to the early Pangea break-up and the subduction of the Pacific plate (Cochrane et al., 2014a; this contribution). Several continental blocks may have been detached from the margin during this extensional event. During the Jurassic several arcs were formed along different segment of the Northern Andean margin and the detached fragments. As suggested by Blanco-Quintero et al. (2014), during the Jurassic some segments of the Northern Andes experienced a collisional event, whereas others were experiencing continuous subduction with the growth of magmatic arcs.

The Tahami terrane in the Colombian Andes and the Salado terrane of the Cordillera Real in Ecuador represent remnants of such Jurassic segments that experienced collision (Fig. 2.1). The Salado terrane in Ecuador consists of interbedded Late Jurassic turbiditic metasedimentary rocks and mafic lavas with associated deformed granitoids (Litherland et al., 1994) sandwiched between the Jurassic Abitagua batholith and the Permo-Triassic Loja terrane (Spikings et al., 2015). Detrital zircons from a metasandstone provided zircon ages 
similar to the mica schists from Colombia, with peak ages in the Mesoproterozoic, Neoproterozoic and Jurassic (Cochrane et al., 2014a). This terrane has been interpreted as formed as an extensional arc setting limited to the east by the Cosanga fault that separate them from undeformed Jurassic granitoids and the Amazon foreland. During the Late Jurassic to Early Cretaceous this terrane also experienced a relatively higher pressure collisional event (Massone and Toulkeridis, 2010). Such along strike variation in the tectonic evolution of the margin reflects both the aforementioned Triassic extension and the oblique convergence experienced by the South American continental margin during the Jurassic. In such scenario the Otú-Pericos marks the site of oblique subduction and collision of the Tahami terrane with the Gondwana margin. Following such events the Otú-Pericos fault change to a strike slip suture that allow the final juxtaposition of the Tahamí and Chibcha terrane (Pindell and Kennan, 2009; Bayona et al., 2006; 2010). This tectonic evolution suggests that the Chibcha and Tahamí are para-autochthonous terranes to the western margin of South America.

\subsection{CONCLUSIONS}

New U-Pb zircon ages combined with $\mathrm{Hf}$ isotopes reveals that the Tierradientro gneisses and amphibolites, traditionally considered as part of the Grenville event of the Colombian Andes, are actually the record of Permo-Triassic extension and subduction processes that affected western Pangea. The Tierradientro unit is limited by the Otú-Pericos fault that forms the eastern border of a Jurassic sequence that includes mica schists in which their younger detrital zircons were dated at c. 162 Ma. Such Jurassic rocks, until now undetected in the Central Cordillera of Colombia, can be correlate to the south with the Salado belt in Ecuador. Initial Hf signatures of the Jurassic detrital zircons are distinct of the nearby magmatic rocks of the same age, which suggest sources far from that located at the western margin Colombia and Ecuador. 


\title{
Capítulo 3
}

\section{Late Jurassic to Early Cretaceous plutonism in the Colombian Andes: a record of long-term arc maturity ${ }^{2}$}

\begin{abstract}
Integrated geochemical, isotopic and geochronological constraints from Jurassic plutonic rocks of the Central Cordillera in Colombia were used to determine the tectonic setting and long-term tectonomagmatic evolution of the northern Andes. We examined three plutonic units with compositions that vary from diorite to granite with $\mathrm{U}-\mathrm{Pb}$ zircon crystallization ages from $165 \mathrm{Ma}$ to $129 \mathrm{Ma}$. These units are interpreted as subduction-related magmas as indicated by their $\mathrm{K}_{2} \mathrm{O}, \mathrm{Na}_{2} \mathrm{O}$ contents, LREE/HREE ratios and $\mathrm{Pb}$ isotope signatures. The $\mathrm{Nd}$ and $\mathrm{Hf}$ isotope compositions of these magmatic events become more juvenile with time. This compositional record suggests an arc maturity trend in which partial melting of basaltic sources becomes more significant than radiogenic subducted sediments or the ancient continental crust. These processes are associated with the oblique convergence of the Farallon oceanic lithosphere against the Andean continental margin during the Mesozoic, which, in combination with the reduction of more fusible components transported by the subduction into the mantle, resulted in decreasing magmatic activity that ceased in the Early Cretaceous. These same characteristics have also been described in the southern Andes and other subduction regimes, suggesting that the evolution of stationary continental arc magmatism involves a progressive juvenile character with time, where the obliqueness in the convergence reduces the amount of sediments to be melted with basalt, rendering the source more refractory and decreasing the volumes of magma trough time.
\end{abstract}

\footnotetext{
${ }^{2}$ Bustamante, C., Archanjo, C., Cardona, A., Valencia, V., Vervoort, J., 2016. Late Jurassic to Early Cretaceous plutonism in the Colombian Andes: a record of long-term arc maturity. Geological Society of America Bulletin.
} 


\subsection{INTRODUCTION}

The Middle Mesozoic convergence of the Farallon oceanic plate beneath the northwestern margin of South America was responsible for the growth of several magmatic arcs and the development of deep sedimentary basins and a major Cretaceous marine transgression (Jaillard et al., 1990, 2000; Toussaint, 1995; Sarmiento-Rojas et al., 2006; Ramos and Aleman, 2000; Ramos, 2009; Pindell and Keenan, 2009). Geological and geochronological data from the Andes of Colombia and Ecuador indicate the existence of a Late Triassic to Late Jurassic magmatism between 203 and 145 Ma (Fig. 3.1; Aspden et al., 1987; Noble et al., 1997; Gendall et al., 2000; Chiaradia et al., 2009; Bustamante et al., 2010; Villagómez et al., 2011; Leal-Mejía, 2011; Álvarez-Galindez, 2013; Mantilla et al., 2013; Cochrane et al., 2014a). This magmatism includes large NNE-trending elongated batholiths commonly associated with volcanic rocks distributed along the eastern margin of the Central Cordillera and the middle and upper Magdalena valley of Colombia (Fig. 3.1; Aspden et al., 1987; Toussaint, 1995).

Two different tectonic models have been proposed for the Jurassic and Early Cretaceous evolution of the Northern Andes. The first model, based on a succession of sedimentary strata and regional paleogeography, proposed that the Jurassic igneous rocks evolved in an intracontinental rift setting (review in Cediel et al., 2003; Pindell and Keenan, 2009). The second model, based on geochemical data of magmatic rocks, proposed a subduction extensional setting characterized by the development of a back-arc and intra-arc tectonic setting (Aspden et al., 1987; Bayona et al., 2006; Bustamante et al., 2010; Villagómez et al., 2011; Cochrane et al, 2014a; Zapata et al., 2016). In the subduction-related model, the long-term evolution of the active margin would be characterized by ocean-ward arc migration due to slab roll-back (Cochrane et al., 2014a). Alternative scenarios include the translation of terranes from southern latitudes in an oblique convergence setting that would juxtapose Jurassic metamorphic terranes with a magmatic arc (Bayona et al., 2006; BlancoQuintero et al., 2014).

Our study examines the Mesozoic evolution of the paleomargin of the Northern Andes from the Jurassic to the Early Cretaceous. In particular, we explore the slab roll-back model to show that there is no connection between the proposed migration of the arc and the age distribution of the continental plutonic rocks. We have analyzed how the long-term increase in the juvenile character of the magmatic record in arcs is controlled by the evolution of a single hybrid sedimentary and mantle source formed in the subduction mélange (Castro et al., 
2010 ; 2013) and show that this does not necessarily reflect of an extensional setting that allow continuous exposure of mantle material. This apparently counter-intuitive character of the maturation of continental arc magmas has been described in other magmatic belts such as in the Southern Andes (Bellos et al., 2015; Hervé et al., 2007), the Iberia magmatic arc (Pereira et al., 2015), and the Central Asian orogenic belt (Li et al., 2014), and therefore can be seen as a major pattern of magmatic arcs.

In this contribution we present new zircon $\mathrm{U}-\mathrm{Pb}$ ages combined with $\mathrm{Hf}$ isotopes, as well as whole-rock $\mathrm{Hf}, \mathrm{Nd}$ and $\mathrm{Pb}$ isotope data and also major and trace element data, from selected plutons of the Colombian Andes (Fig. 3.1). The new results, combined with previous studies, are used to constrain the tectonomagmatic evolution of the Central Cordillera between 165 and $129 \mathrm{Ma}$. These results are consistent with the existence of a more stationary arc that resulted from diminishing magmatic fertility as a consequence of the long-term evolution of the magma sources and the plate convergence obliquity. A similar evolutionary history can be found in the Jurassic record of the Ecuadorian Andes (Chiaradia et al., 2009) and suggests that regional stationary arc maturation reflects source and regional tectonic controls.

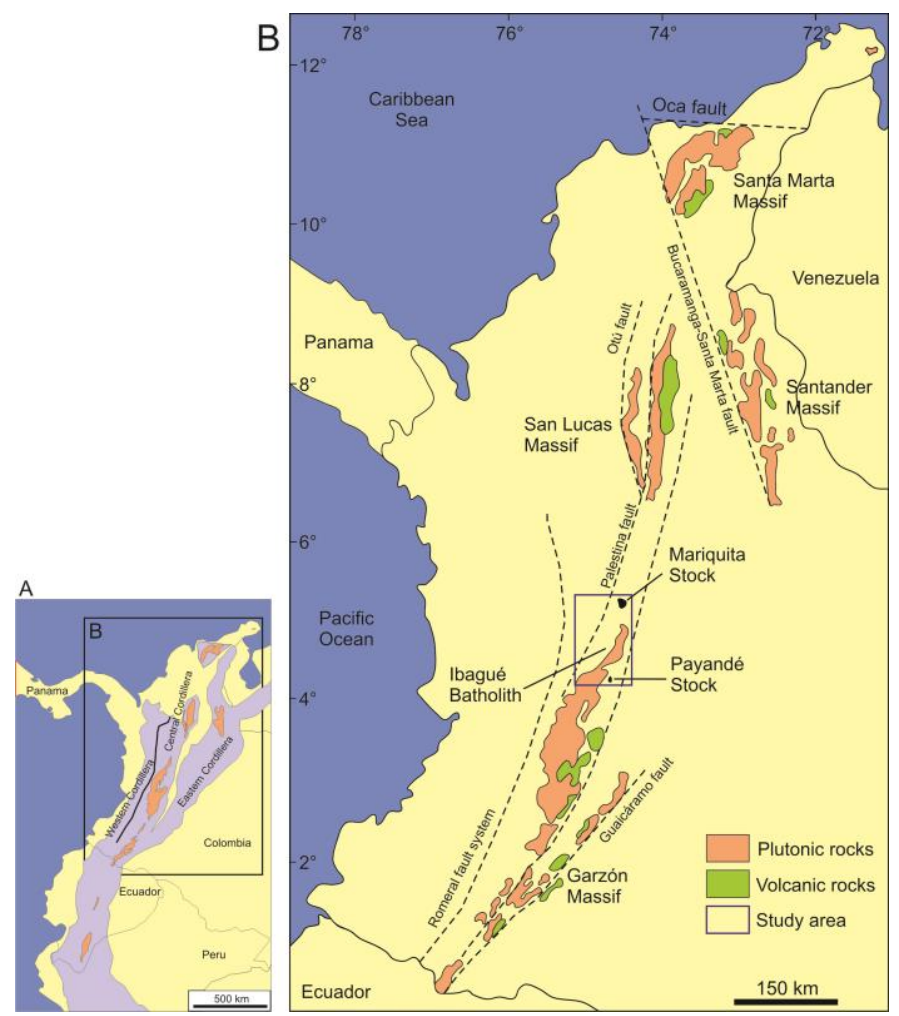

Figure 3.1. A: Distribution of the Jurassic plutonic belt in the Northern Andes. B: Detailed map of the occurrences of Lower Jurassic to Lower Cretaceous plutonic rocks in the Central Cordillera of Colombia and isolated massifs with associated volcanic rocks. 


\subsection{GEOLOGICAL SETTING}

The Northern Andes of Colombia are characterized by three mountain ranges separated by major rivers that drain to the Caribbean Sea (Fig. 3.1). The Central Cordillera has an extensive Meso-Cenozoic magmatic record characterized by a series of plutonic bodies considered to be Late Jurassic to Late Cretaceous in age (Aspden et al., 1987; Villagómez et al., 2011). These rocks intrude the Permo-Triassic and older metamorphic basement (Vinasco et al., 2006; Restrepo et al., 2011; Villagómez et al., 2011; Martens et al., 2014). The Mesozoic magmatic record is related to a volcanic arc formed by the subduction of the Farallon Plate beneath NW South America (Aspden et al., 1987; Villagómez et al., 2011; Cochrane et al., 2014a). Jurassic arc-related magmatism extends towards the Middle and Upper Magdalena valley as a series of volcanic rocks included in the Saldaña Formation (Fig. 3.1) (Bayona et al., 1994). Older Early Triassic red sandstones and conglomerates overlain by carbonates (Luisa and Payandé Formations) lie below these volcanic rocks and are related to an extensional rift-related setting associated with the break-up of Pangea or the opening of the Proto-Caribbean Ocean (Cediel et la., 2003; Pindell and Keenan, 2009).

The western Cordillera is characterized by a series of allochthonous Cretaceous oceanic terranes that have accreted to the continental margin since the Late Cretaceous (Restrepo and Toussaint, 1988; Kerr et al., 1997; Villagómez et al., 2011; Villagómez and Spikings, 2013). The Eastern Cordillera also includes a more limited Late Triassic to Early Jurassic siliciclastic series covered by an extensive Early Cretaceous transgressive sequence, with well-defined extensional structures (Sarmiento-Rojas et al., 2006) and limited small gabbroic plutons of Early to Late Cretaceous in age (Vásquez and Altenberger, 2005, Vásquez et al., 2009).

\subsubsection{Mesozoic plutonism in the southern Central Cordillera and the Upper Magdalena valley}

The Ibagué Batholith (Fig. 3.1) is one of the largest Jurassic plutons of the Central Cordillera, located at its central to southern segment. It covers an area of approximately $11,700 \mathrm{~km}^{2}$, and includes several intrusions with compositions ranging from tonalite to granodiorite. This batholith intrudes a pre-Jurassic metamorphic basement and is in faulted contact with Jurassic and Tertiary sedimentary rocks (Vesga and Barrero, 1978). Available U$\mathrm{Pb}$ and $\mathrm{K}-\mathrm{Ar}$ geochronological data show that the batholith ranges in age from $189 \mathrm{Ma}$ in the southernmost segment (Bustamante et al., 2010; Leal-Mejía., 2011), to 177 and $145 \mathrm{Ma}$ in the 
north (Vesga and Barrero, 1978; Sillitoe et al., 1982; Brook, 1984; Aspden et al., 1987; Altenberger and Concha, 2005; Villagómez et al., 2011; Leal-Mejía, 2011). To the east, the Ibagué Batholith is probably in tectonic contact with metamorphosed volcano-sedimentary rocks included in the Cajamarca Complex (Blanco-Quintero et al., 2014). The metamorphism of part of these metamorphic complexes apparently took place in the Jurassic between $158 \mathrm{Ma}$ and $147 \mathrm{Ma}$, which is when magmatism was active to the east; therefore, the metamorphism probably took place in an allochthonous position and was subsequently juxtaposed to its current position (Blanco-Quintero et al., 2014). The Payandé stock (Fig. 3.1), which intrudes Late Triassic carbonate rocks, is exposed east of the Ibagué Batholith. Other Jurassic plutons to the south of the Ibagué Batholith include the Altamira, Las Minas and Garzón granites (Bustamante et al., 2010) and the southernmost Mocoa Batholith (Aspden et al., 1987; Zapata et al., 2016).

Early Cretaceous plutons are limited and may include the Mariquita stock (Fig. 3.1), with an approximate area of $65 \mathrm{~km}^{2}$ and compositions ranging from granodiorite to tonalite (Barrero and Vesga, 1976). These plutons intrude metamorphic rocks of the Cajamarca Complex. These have been covered by Tertiary sedimentary rocks. K-Ar dates in biotite of $113 \pm 4$ Ma (Barrero and Vesga, 1976; Vesga and Barrero, 1978), are considered minimum dates and are related to cooling.

Late Cretaceous 90-65 Ma calc-alkaline magmatism is represented by the ca. 8,000 $\mathrm{km}^{2}$ areal exposure of the Antioquian batholith and other smaller intrusive bodies that are widely exposed in the northern segment of the Central Cordillera (Ibáñez-Mejía et al., 2007; Restrepo-Moreno et al., 2007; Ordóñez and Pimentel, 2001; Ordóñez-Carmona et al., 2007; Leal-Mejía et al., 2011; Villagómez et al., 2011).

\subsection{SAMPLING AND ANALYTICAL METHODS}

We have focused our work on the plutonic record exposed in the central segment of the Central Cordillera, north of the Ibagué fault and east of the Romeral fault system, including the Ibagué batholith and the Payandé and Mariquita stocks (Fig. 3.1). The Ibagué batholith and Mariquita stock intrude greenschist-facies metamorphic rocks of the Cajamarca Complex, whereas the Payandé stock intrudes Triassic limestones of the Payandé formation forming Cu-skarn deposits (Barrero, 1969; Alvarán et al., 2011).

A total of 50 samples were taken from the Ibagué batholith (18), Mariquita stock (30) and Payandé stock (2). Petrography was performed on thin sections from all 50 samples to 
identify mineralogy and textural features, and also as a guide to select representative samples for geochemical analyses and for U-Pb geochronology.

\subsubsection{U-Pb Geochronology in zircon}

Heavy mineral concentrates of the $<350 \mu \mathrm{m}$ fraction were separated using traditional techniques. Zircons from the non-magnetic fraction were handpicked under the microscope and mounted in a 1-inch diameter epoxy puck and slightly ground and polished to expose the surface and keep as much material as possible for laser ablation analyses. After CL imaging, the LA-ICP-MS U-Pb analyses were conducted using a New Wave Nd:YAG UV 213-nm laser coupled to a ThermoFinnigan Element 2 single collector, double-focusing, magnetic sector ICP-MS at Washington State University. Operating procedures and parameters are similar to those of Chang et al. (2006). Laser spot size and repetition rate were 30 microns and $10 \mathrm{~Hz}$, respectively. He and Ar carrier gases delivered the sample aerosol to the plasma. Each analysis consists of a short blank analysis followed by 250 sweeps through masses 202, 204, 206, 207, 208, 232, 235, and 238, taking approximately 30 seconds. Fractionation was corrected by normalizing $\mathrm{U} / \mathrm{Pb}$ and $\mathrm{Pb} / \mathrm{Pb}$ ratios of the unknowns to the zircon standards (Chang et al., 2006). U and Th concentration were monitored by comparing to NIST 610 trace element glass. Zircon standard Plesovice was used, with an age of $337.13 \pm 0.37 \mathrm{Ma}$ (Sláma et al., 2008). Uranium-lead ages (Table 3.1) were calculated using Isoplot 4.15 (Ludwig, 2003).

\subsubsection{Hf isotopes in zircon}

Hf isotope geochemistry analysis was performed on 12 samples (Table 3.2) at the Geoanalytical Lab at Washington State University, using a ThermoFinnigan Neptune ${ }^{\mathrm{TM}} \mathrm{MC}$ ICP-MS equipped with 9 faraday collectors interfaced with a New Wave ${ }^{\mathrm{TM}} 213 \mathrm{~nm}$ UP NdYAG laser. Laser spot size was $40 \mu \mathrm{m}$ and the data were acquired in static mode with 60 second integrations. Details of analytical procedures and data treatment follow those of Vervoort et al. (2004) and DuFrane et al. (2007). For the Hf-depleted mantle model ages $\left(\mathrm{Hf}_{\mathrm{TDM}}\right)$, we used ${ }^{176} \mathrm{Hf} /{ }^{177} \mathrm{Hf}$ and ${ }^{176} \mathrm{Lu} /{ }^{177} \mathrm{Hf}$ for the individual zircon samples to determine their initial ${ }^{176} \mathrm{Hf} /{ }^{177} \mathrm{Hf}$ ratios at their crystallization ages. Projection back from zircon crystallization was calculated using a present value of 0.0150 for the estimated ${ }^{176} \mathrm{Lu} /{ }^{177} \mathrm{Hf}$ of continental crust (Vervoort and Patchett, 1996; Goodge and Vervoort, 2006). The depleted 
mantle Hf evolution curve was calculated from present-day depleted mantle values of ${ }^{176} \mathrm{Hf} /{ }^{177} \mathrm{Hf} \mathrm{DM}_{(0)}=0.283240$ and ${ }^{176} \mathrm{Lu} /{ }^{177} \mathrm{Hf} \mathrm{DM}_{(0)}=0.03979$ (Vervoort et al., 2015).

\subsubsection{Whole rock XRF and ICP-MS geochemistry}

Bulk whole rock chemical analyses of 23 samples were determined, avoiding veins and weathered surfaces. The samples were crushed using a jaw crusher and powdered using a tungsten carbide ring mill. Major and trace elements were analyzed using a Rigaku $3370 \mathrm{XRF}$ spectrometer at Washington State University. Details of sample preparation, dilution and analytical procedures are described in Johnson et al. (1999). Major, trace and rare earth element results are reported in Table 3.3.

REE were determined by inductively coupled plasma-mass spectrometry (ICP-MS) at Washington State University. A 2 g aliquot is weighed into a graphite crucible and mixed with $2 \mathrm{~g}$ of $\mathrm{LiBO}_{2}$ flux. The crucibles are placed in an oven and fused at $1000^{\circ} \mathrm{C}$ in a muffle furnace for 30 minutes. The resultant bead is ground in a steel ring mill, and a $0.25 \mathrm{mg}$ portion is dissolved using $\mathrm{HNO}_{3}(2 \mathrm{ml}), \mathrm{HF}(6 \mathrm{ml})$ and $\mathrm{HClO}_{4}(2 \mathrm{ml})$ at $110^{\circ} \mathrm{C}$. Calibration standards and reagent blanks are added to the sample sequence. Sample solutions are aspirated into an ICP emission spectrograph (Jarrel Ash Atom Comb 975) for determining major oxides and certain trace elements ( $\mathrm{Ba}, \mathrm{Nb}, \mathrm{Ni}, \mathrm{Sr}, \mathrm{Sc}, \mathrm{Y}$ and $\mathrm{Zr}$ ), while the sample solutions are aspirated into an ICP-MS (Perkins-Elmer Elan 6000) for determination of the trace elements, including rare earth elements.

\subsection{4. $\mathrm{Nd}$, $\mathrm{Hf}$ and $\mathrm{Pb}$ radiogenic isotopes}

Analyses were acquired using a Thermo-Finnigan Neptune multicollector system at Washington State University and results are presented in Table 3.4. Procedures for sample preparation and dilution details for $\mathrm{Nd}, \mathrm{Hf}$ and $\mathrm{Pb}$ isotopes are those as in Gaschnig et al. (2011). A final Hf purification was performed following Münker et al. (2001); Lu was separated from $\mathrm{Yb}$ according to (Vervoort et al., 2004) and for Sm and $\mathrm{Nd}$ were prepared by following the procedures described in Vervoort and Blichert-Toft (1999). $\mathrm{Pb}$ was separated using the Tl doping method of White et al. (2000). After correcting for the mass bias using the $\mathrm{Tl}$, samples were normalized to the triple-spike values for NBS-981 from Galer and Abouchami (1998).

$\mathrm{Nd}$ analyses were corrected for mass fractionation using ${ }^{146} \mathrm{Nd} /{ }^{144} \mathrm{Nd}=0.7219$ and normalized using the Ames $\mathrm{Nd}$ standard $( \pm 0.0000202 \sigma$ average reproducibility), and $\mathrm{Hf}$ 
analyses were corrected using ${ }^{179} \mathrm{Hf} /{ }^{177} \mathrm{Hf}=0.7325$ and the JMC-475 standard $( \pm 0.0000142 \sigma$ average reproducibility). Sm was corrected using ${ }^{147} \mathrm{Sm} /{ }^{152} \mathrm{Sm}=0.56081$. Lu measurements are according to the methods of Vervoort et al. (2004). $\varepsilon_{\mathrm{Nd}}$ values were calculated using present day values of ${ }^{143} \mathrm{Nd} /{ }^{144} \mathrm{Nd}=0.512630$ and ${ }^{147} \mathrm{Sm} /{ }^{144} \mathrm{Nd}=0.160$ for CHUR (Bouvier et al., 2008), and $\varepsilon_{\mathrm{Hf}}$ using present-day values of ${ }^{176} \mathrm{Hf} /{ }^{177} \mathrm{Hf}=0.282785$ and ${ }^{176} \mathrm{Lu} /{ }^{177} \mathrm{Hf}=0.0336$ for CHUR (Bouvier et al., 2008).

\subsection{RESULTS}

\subsubsection{Zircon U-Pb geochronology}

Scanning Electron Microscope Cathodoluminescence (SEM-CL) images are shown in Figure 2, and crystallization ages from representative zircon grains analyzed are shown in Figure 3 to 5. Approximately 30 zircon tips were analyzed per sample. Th/U ratios for these analyses are less than 12, which is typical of magmatic zircon (Rubatto, 2002).

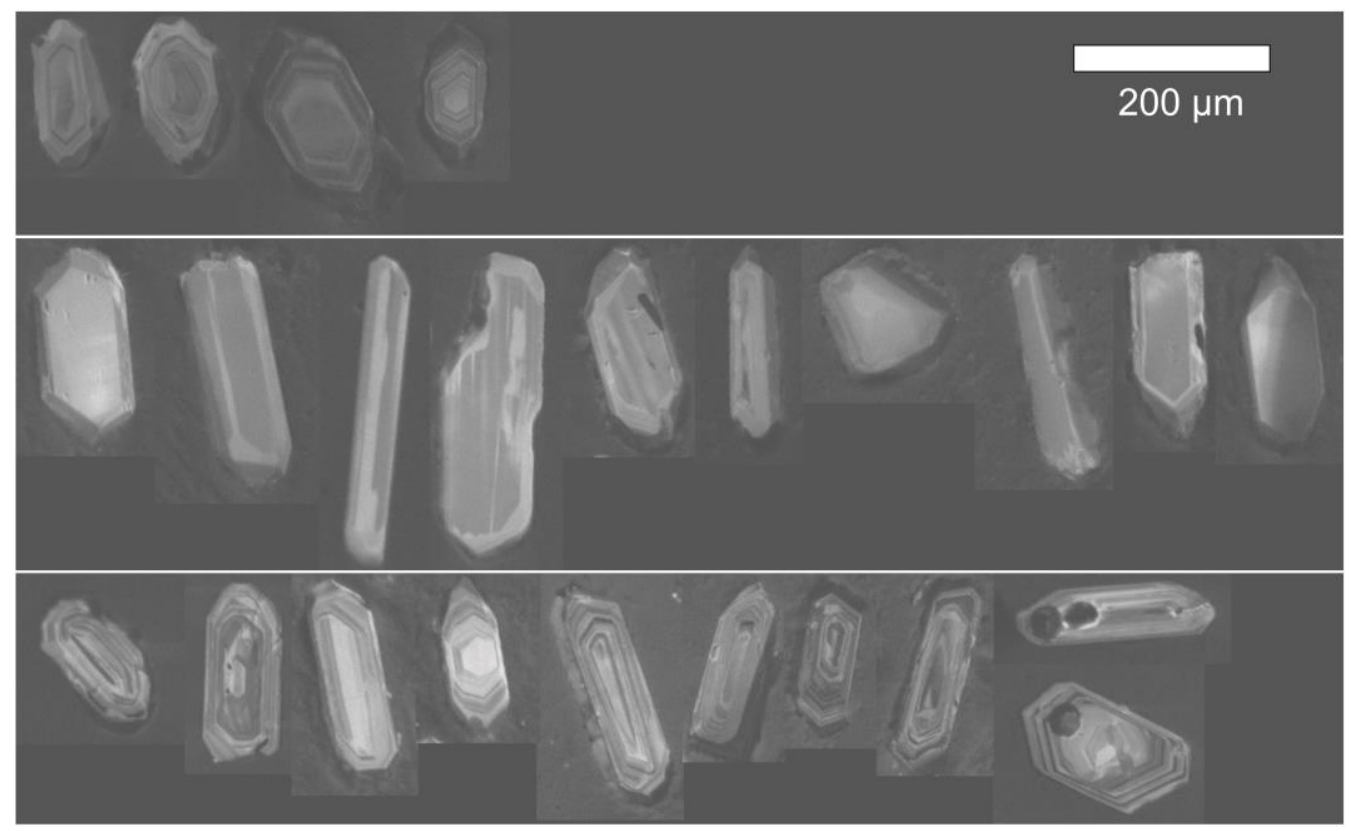

Figure 3.2. Representative Scanning Electron Microscope Cathodoluminescence (SEM-CL) images from zircon grains of each pluton studied. Upper: Payandé stock, middle: Ibagué batholith, bottom: Mariquita stock.

Two samples from the Payandé stock are characterized by short prismatic to rounded zircon grains with typical lengths of 100 to $250 \mu \mathrm{m}$ and well-defined oscillatory zoning and lack of overgrowths. Inherited cores were not observed in the CL images (Fig. 3.2). The ages obtained for this granitoid are ca. 165-164 Ma (Middle Jurassic) (Fig. 3.3). 

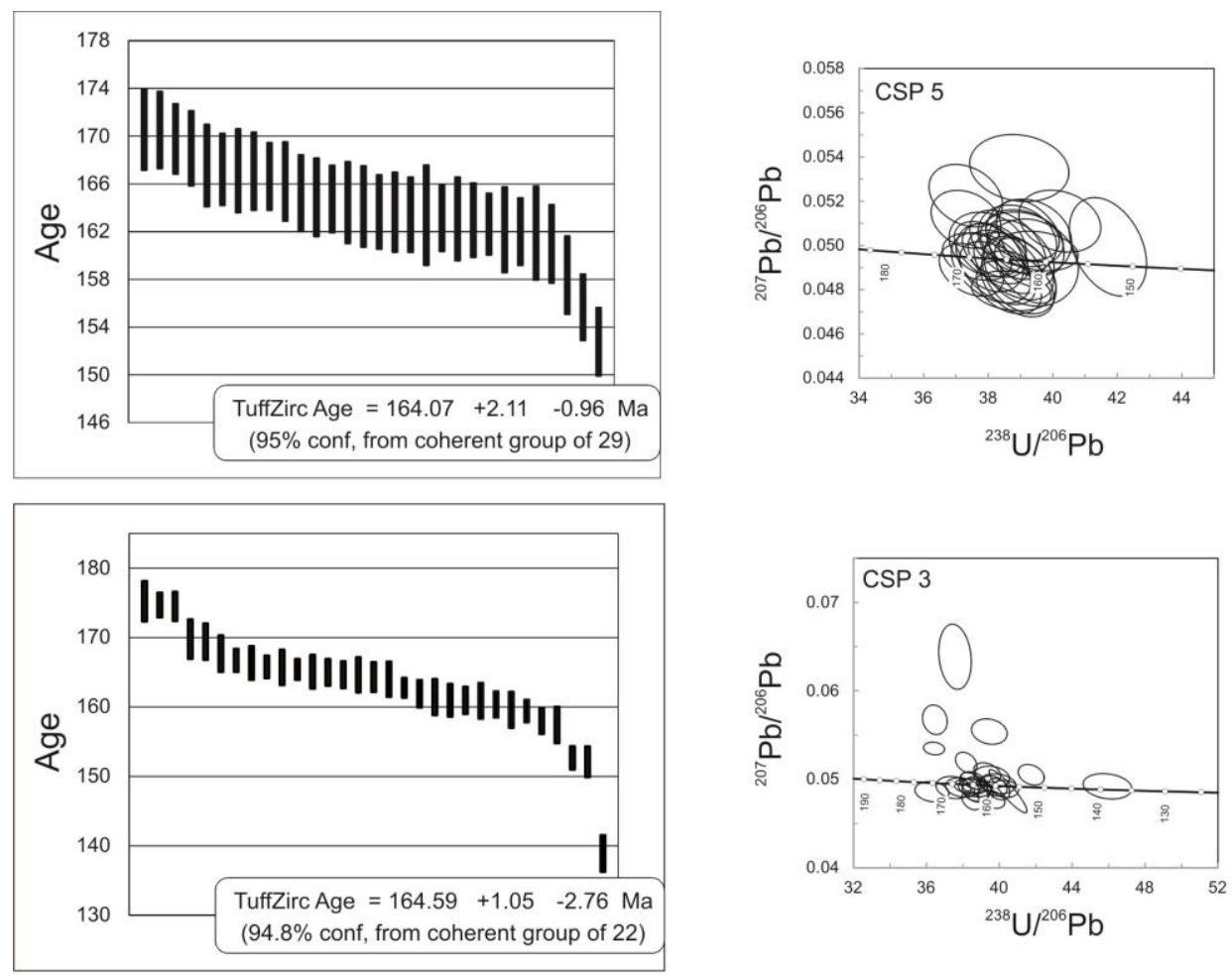

Figure 3.3. U-Pb zircon ages with $1 \sigma$ box heights and Tera-Wasserburg diagrams with $68.3 \%$ confidence error ellipses from the Payandé stock.

The six samples from the Ibagué Batholith have elongated prismatic zircon with sizes between 100 to $300 \mu \mathrm{m}$ (Fig. 3.2). Zoning is nearly absent, although it can be present in shortprismatic crystals from dioritic samples. Ages were obtained from tips and range from Lower Cretaceous (granodiorite: $141.9+1.1 /-0.8 \mathrm{Ma}$ ) to Upper Jurassic (diorite: 158.2 +1.2/-0.4 Ma) (Fig. 3.4). 

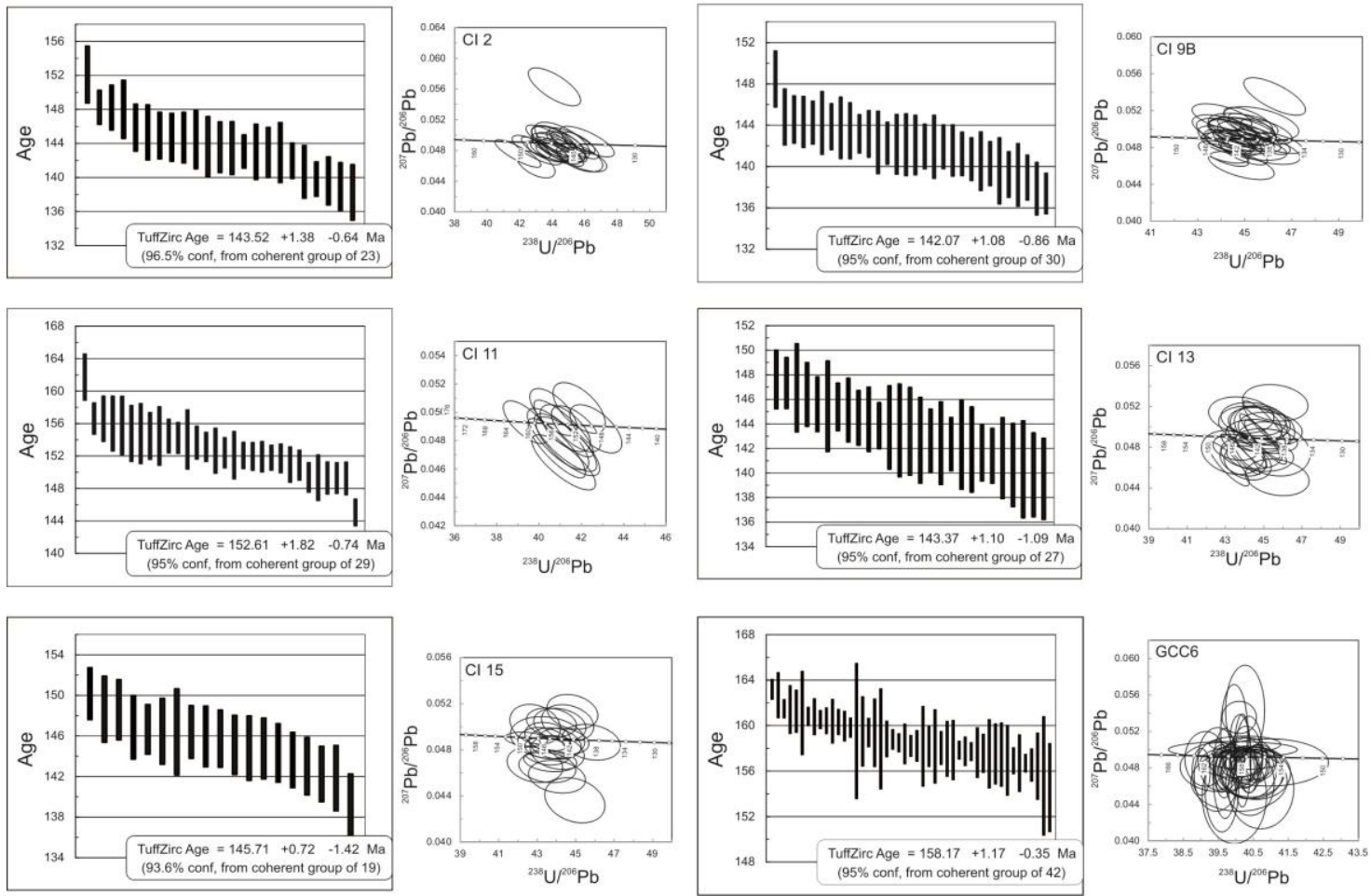

Figure 3.4. $\mathrm{U}-\mathrm{Pb}$ zircon ages with $1 \sigma$ box heights and Tera-Wasserburg diagrams with $68.3 \%$ confidence error ellipses from the Ibagué Batholith.

Lower Cretaceous ages were obtained from seven samples of the Marquita stock. Short, prismatic zircon show clear oscillatory concentric zoning patterns and a larger range of sizes from $\sim 75$ to $350 \mu \mathrm{m}$, although short crystals are more common (Fig. 3.2). A trend of older ages in the south to younger in the north is evident from the results, with ages ranging from 143.4 +0.6/-0.7 Ma in the south to 129.2+1.1/-1.0 Ma in the north (Fig. 3.5). 

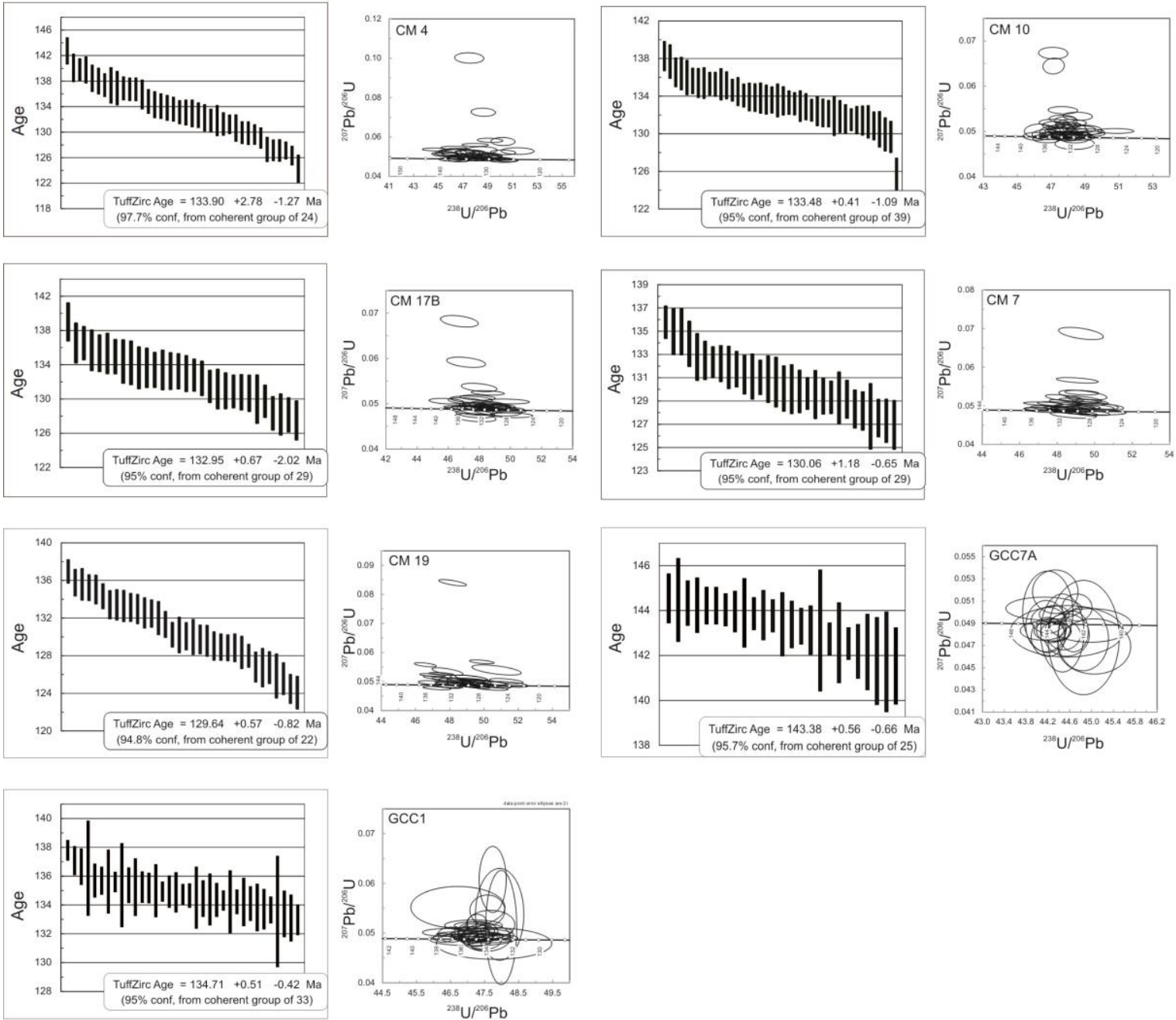

Figure 3.5. U-Pb zircon ages with $1 \sigma$ box heights and Tera-Wasserburg diagrams with $68.3 \%$ confidence error ellipses from the Mariquita stock.

\subsubsection{Whole-rock elemental and isotope geochemistry, and Hf isotopes in zircon}

A total of 23 samples were analyzed from the Ibagué, Payandé, and Mariquita plutonic bodies, whereas seven samples were chosen for whole-rock $\mathrm{Nd}, \mathrm{Pb}$ and $\mathrm{Hf}$ isotopes, and $\mathrm{Hf}$ isotopic analyses were obtained for the twelve dated samples. Isotopic ratios were calculated using $\mathrm{U}-\mathrm{Pb}$ ages in zircon and are reported in Table 3.4.

Harker diagrams (Fig. 3.6) are characterized by decreases in $\mathrm{Al}_{2} \mathrm{O}_{3}, \mathrm{MgO}, \mathrm{TiO}_{2}, \mathrm{CaO}$, $\mathrm{FeO}_{\mathrm{t}}$ and an increase in $\mathrm{K}_{2} \mathrm{O}$ relative to $\mathrm{SiO}_{2} . \mathrm{Na}_{2} \mathrm{O}$ is scattered for all of the samples in the different plutons and is probably associated with plagioclase alteration. The element distribution patterns suggest fractional crystallization of mafic phases that is a common process in the studied plutons. 


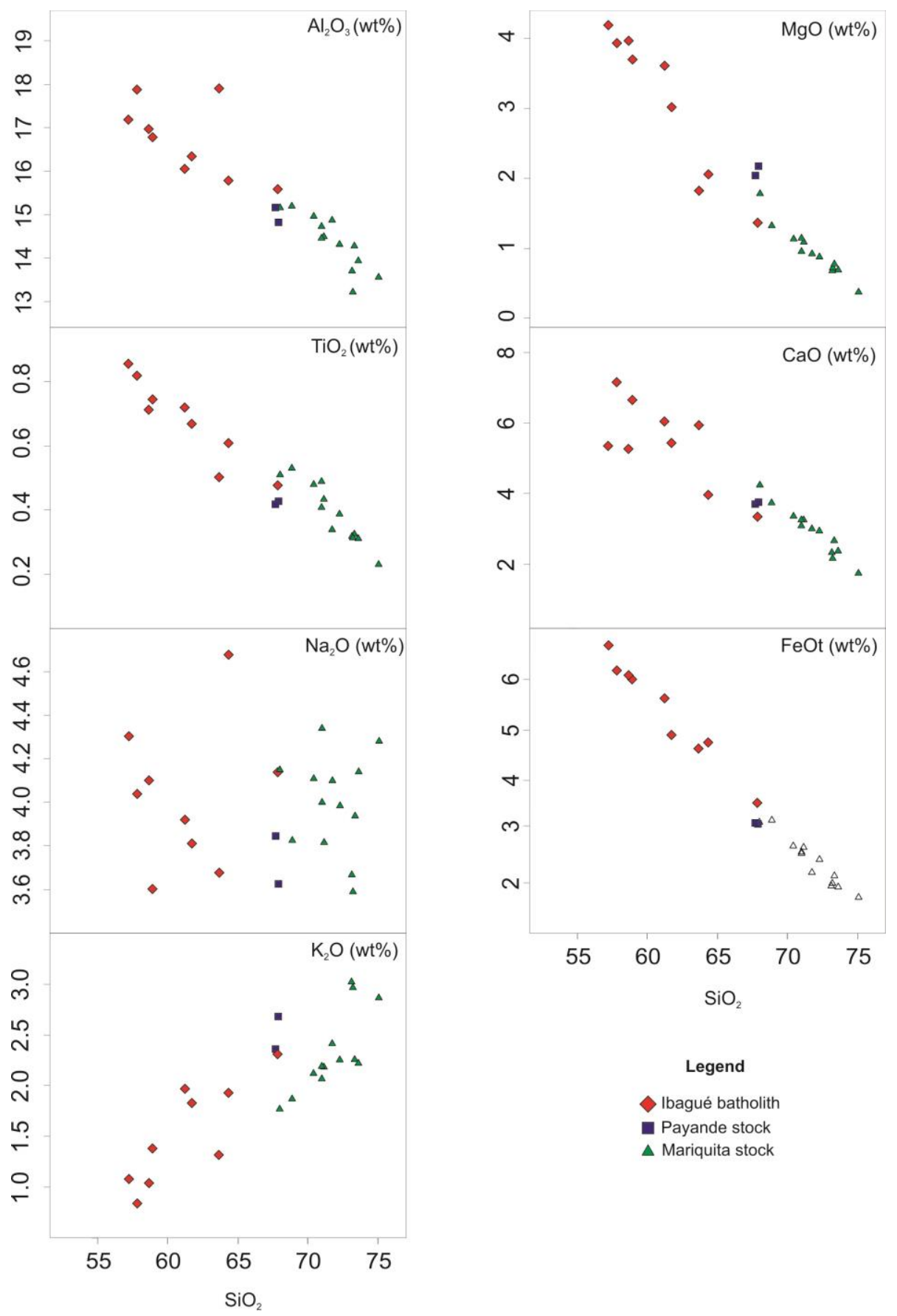

Figure 3.6. Harker diagrams of the three studied plutons, showing how fractional crystallization is a common process among them.

The loss on ignition for the majority of the analyzed samples is less than $1.5 \mathrm{wt} \%$, with three samples achieving values of ca. $2.3 \mathrm{wt} \%$ that reflect an intermediate degree of alteration (also seen in thin section). All samples have an intermediate to felsic composition (Fig. 3.7A) and are calc-alkaline according to the alkalinity index (Fig. 3.7B) of Pecerillo and Taylor (1976). They are also predominantly metaluminous to slightly peraluminous in some 
Mariquita samples, as shown in the diagram of Shand (1943) (Fig. 3.7C). The latter probably reflects higher amounts of biotite. Multi-element diagrams normalized with respect to the primitive mantle (Sun and McDonough, 1989) show that all samples exhibit characteristics of a subduction-related environment, which are reflected in the enrichments of $\mathrm{K}, \mathrm{Rb}$ and $\mathrm{Ba}$ and in the negative anomalies in $\mathrm{Nb}$ and $\mathrm{Ti}$ (Fig. 3.8). Details from each pluton will be described in the following sections.
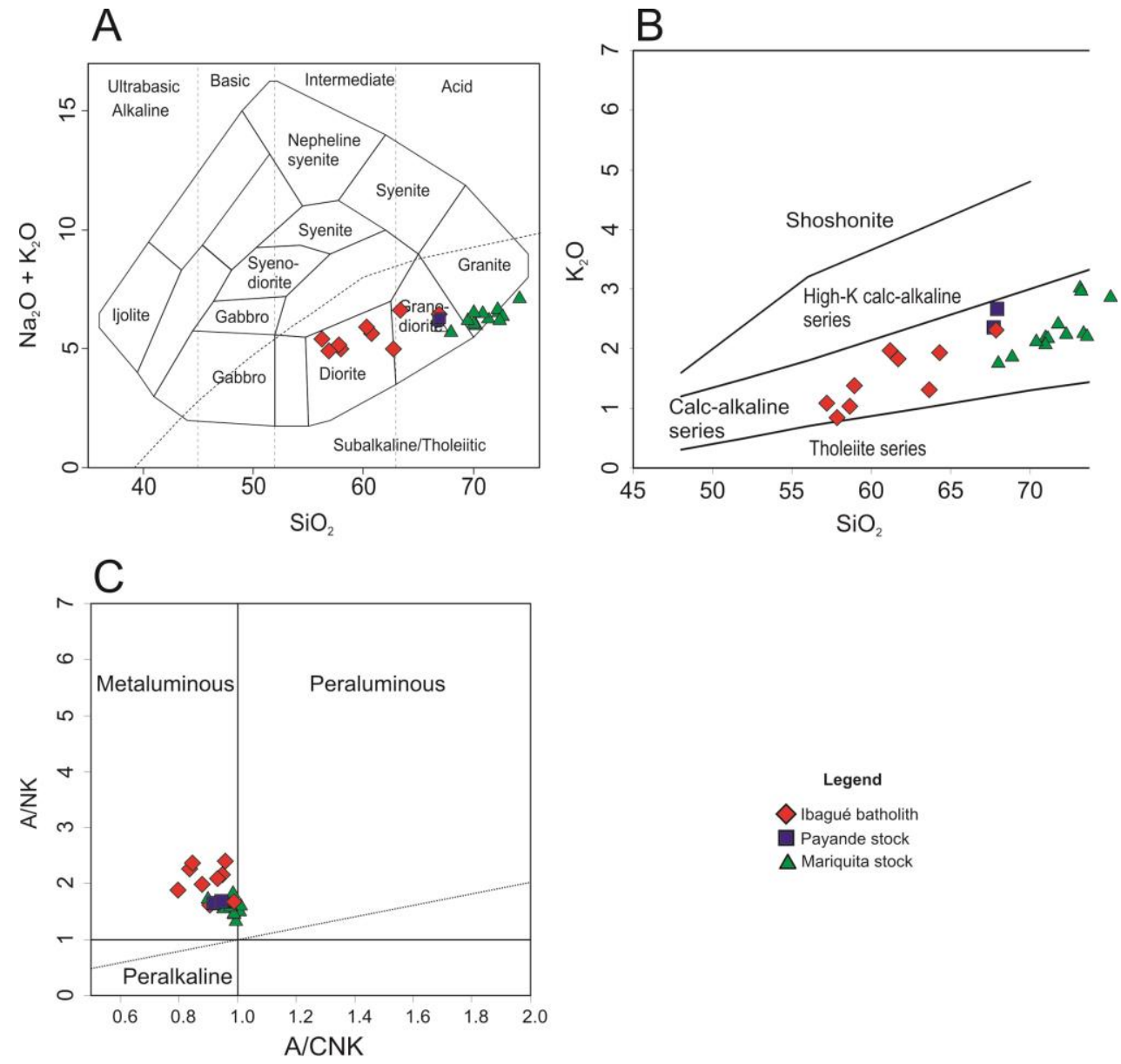

\section{Legend}

Ibagué batholith

Payande stock

$\triangle$ Mariquita stock

Figure 3.7. Geochemical classification and discrimination diagrams of samples from the three studied plutons. A: Classification of plutonic rocks based on the TAS diagram of Cox et al. (1979). B: Alkalinity index diagram of Pecerillo and Taylor (1976). C: Alumina saturation index diagram of Shand (1943). 


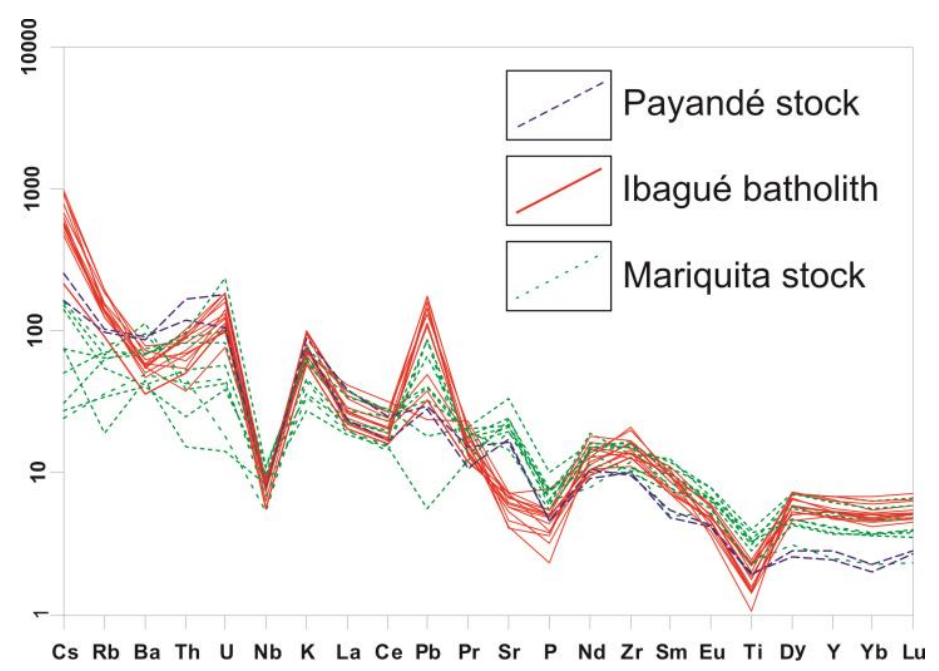

Figure 3.8. Multi-element plot normalized to primitive mantle according to Sun and McDonough (1989).

\subsubsection{Payandé stock}

Samples from the Payandé stock are composed of plagioclase, quartz, orthoclase, Caamphibole and biotite. Zircon, apatite and tourmaline are common accessories. The samples plot in the granodiorite field of the TAS diagram (Cox et al., 1979) and have relatively high average $\mathrm{SiO}_{2}(\sim 68 \mathrm{wt} \%)$, low $\mathrm{K}_{2} \mathrm{O}(2.5 \mathrm{wt} \%)$, similar values of $\mathrm{CaO}$ and $\mathrm{Na}_{2} \mathrm{O}$ (3.8 and 3.7 $\mathrm{wt} \%$, respectively), and a $\mathrm{MgO}$ content of $2.1 \mathrm{wt} \%$. Both samples analyzed have relatively high $\mathrm{Sr} / \mathrm{Y}$ ratios (28.2 and 31.7). REE patterns (Fig. 3.9) normalized to chondrite after Nakamura (1974) show moderate enrichment in light rare earth elements (LREE) when compared with heavy rare earth elements (HREE), and they exhibit a steeper pattern compared with the other plutons $\left([\mathrm{La} / \mathrm{Yb}]_{\mathrm{N}} \approx 13.6\right)$. Eu anomalies are absent $(\mathrm{Eu} / \mathrm{Eu} * \approx 1)$, and an almost flat-shaped pattern for the MREE-HREE is common for the studied granites $\left([\mathrm{Dy} / \mathrm{Yb}]_{\mathrm{N}} \approx 1.2\right)$. The whole-rock $\varepsilon_{\mathrm{Nd}(\mathrm{i})}$ and $\varepsilon_{\mathrm{Hf}(\mathrm{i})}$ values of the analyzed samples are lower than in the other plutons $(+2.2$ and +3.9 , respectively). This finding is consistent with the Hf isotopes in zircon, where the $\varepsilon_{\mathrm{Hf}(\mathrm{i})}$ values range from +2.3 to +4.1 . The ${ }^{206} \mathrm{~Pb} /{ }^{204} \mathrm{~Pb}$ ratio is $18.80,{ }^{208} \mathrm{~Pb} /{ }^{204} \mathrm{~Pb}$ is 38.55 and ${ }^{207} \mathrm{~Pb} /{ }^{204} \mathrm{~Pb}$ is 15.62 . 


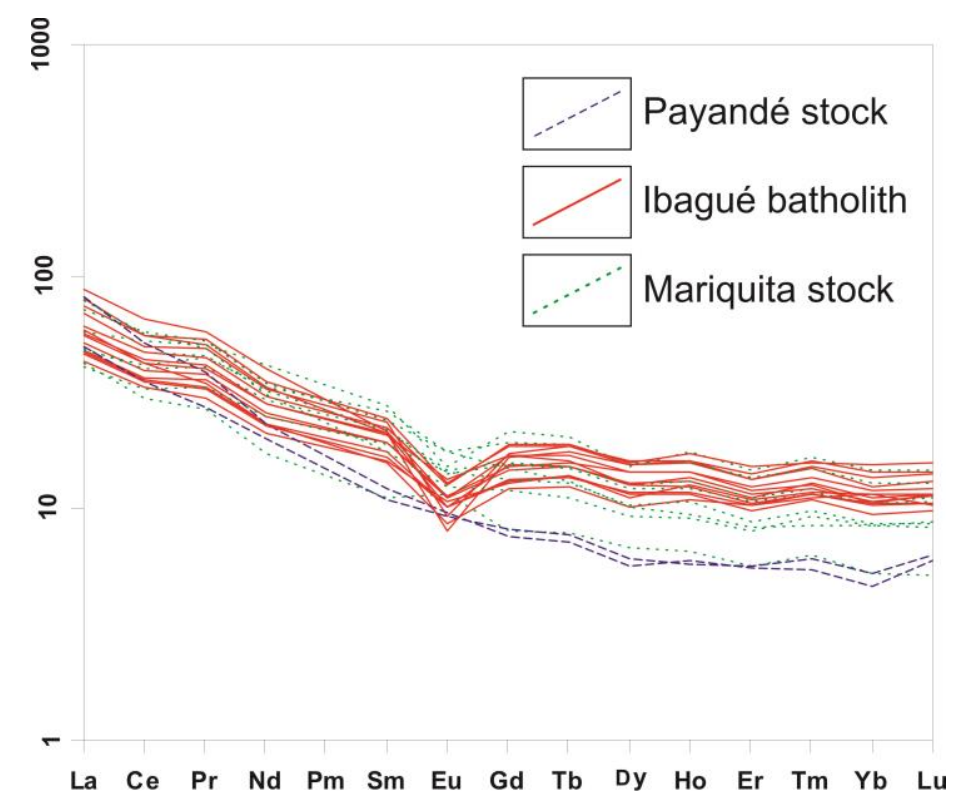

Figure 3.9. Chondrite normalized REE patterns according to Nakamura (1974).

\subsubsection{Ibagué Batholith}

The Ibagué Batholith (Fig. 3.1) was sampled north of the Ibagué fault. In terms of petrography, this batholith shows marked differences in texture and mineral content from the north to the south. The main compositions of the northern half of the batholith are tonalite to granodiorite with $\mathrm{Ca}$-amphibole and biotite. The $\mathrm{Fe}-\mathrm{Mg}$ silicates in these rocks are usually replaced by chlorite. Plagioclase is generally altered to saussurite. Accessory phases are zircon, apatite and ilmenite. Diorites with roughly oriented fabrics defined by the preferred orientation of amphibole are exposed in the middle-southern part of the batholith. Diopside is locally rimmed by $\mathrm{Ca}$-amphibole. In most mafic rocks in this segment, enstatite-ferrosilite, which is also rimmed by Ca-amphibole, is present in the same proportion as diopside. Most Ca-amphiboles have a skeletal appearance caused by multiple quartz inclusions. Some tourmaline and sphene are common as accessory minerals, and xenotime sometimes occurs as inclusions in Ca-amphibole and occurs exclusively in the most mafic rocks. Interstitial orthoclase is identified in some samples, as well as prehnite filling and bent biotite cleavages.

An intermediate composition is reflected in the TAS diagram (Fig. 3.7a) of Cox et al. (1979), and the samples are classified as diorites and granodiorites. $\mathrm{SiO}_{2}$ contents are intermediate $(57.2-67.8 \mathrm{wt} \%)$, and $\mathrm{K}_{2} \mathrm{O}$ is low $(0.8-2.3 \mathrm{wt} \%)$. $\mathrm{CaO}$ exhibits a relatively wide range of values, which reflects the felsic and mafic facies $(3.4-7.2 \mathrm{wt} \%)$, whereas $\mathrm{Na}_{2} \mathrm{O}$ has steady values $(\sim 4.1 \mathrm{wt} \%)$. $\mathrm{MgO}$ values are variable $(1.4-4.2 \mathrm{wt} \%)$. The rocks 
have intermediate to high $\mathrm{Sr} / \mathrm{Y}$ ratios $(14.6$ - $37.9 \mathrm{wt} \%)$ and the Ibagué Batholith has fairly steep REE patterns $\left([\mathrm{La} / \mathrm{Yb}]_{\mathrm{N}}=3.8\right.$ - 9.4) (Fig. 3.9). Multi-element diagrams normalized to chondrite (Nakamura, 1974) show moderate enrichment in LREE compared with HREE. Eu anomalies are absent to slightly negative, and only sample CI7 has a positive anomaly $\left(\mathrm{Eu} / \mathrm{Eu}^{*}=0.6-1.2\right)$. The MREE-HREE pattern is flat-shaped $\left([\mathrm{Dy} / \mathrm{Yb}]_{\mathrm{N}}=1.04-1.29\right)$.

Whole-rock isotopes and $\mathrm{Hf}$ isotopes in zircon from the Ibagué Batholith have intermediate values compared with the Payandé and Mariquita stocks. $\varepsilon_{\mathrm{Nd}(\mathrm{i})}$ ranges from +0.8 to +4.2 , and whole-rock $\varepsilon_{\mathrm{Hf}(\mathrm{i})}$ ranges from +4.4 to +7.6 . Hf isotope analyses in zircon yielded $\varepsilon_{\mathrm{Hf}(\mathrm{i})}$ values from +4.0 to +7.9 . ${ }^{206} \mathrm{~Pb} /{ }^{204} \mathrm{~Pb}$ ratios are from 18.50 to 18.71 , and ${ }^{208} \mathrm{~Pb} /{ }^{204} \mathrm{~Pb}$ ranges from 38.28 to 39.10 . The ${ }^{207} \mathrm{~Pb} /{ }^{204} \mathrm{~Pb}$ values range from 15.59 to 15.62 .

\subsubsection{Mariquita stock}

The Cretaceous Mariquita stock is composed of quartz, plagioclase, orthoclase, Caamphibole and biotite. It differs from the Jurassic plutons by the higher amount of orthoclase and sometimes by a poikilitic texture defined by chadacrysts of plagioclase and biotite. Euhedral zoned biotite crystals and allanite are present to the south of the stock, whereas rutile inclusions in biotite are identified in the north.

An acidic composition is reflected in the TAS diagram (Fig. 3.7a) of Cox et al. (1979), and the rocks are classified as granites. The Mariquita stock has high $\mathrm{SiO}_{2}(68.0-75.1 \mathrm{wt} \%)$, low $\mathrm{K}_{2} \mathrm{O}(1.8-3.0 \mathrm{wt} \%)$, low $\mathrm{CaO}(1.3-1.7 \mathrm{wt} \%)$ and $\mathrm{Na}_{2} \mathrm{O}$ values similar to those of the other plutons (3.6 - 4.3 wt\%). $\mathrm{MgO}$ values are low (0.4 - $1.8 \mathrm{wt} \%)$, and $\mathrm{Sr} / \mathrm{Y}$ ratios are very low (3.0 - 6.9). As in the Ibagué Batholith, REE patterns of all analyzed samples (Fig. 3.9) are coherent having LREE enrichment $\left([\mathrm{La} / \mathrm{Yb}]_{\mathrm{N}}=3.7-8.2\right.$, distinctive negative Euanomalies $\left(\mathrm{Eu} / \mathrm{Eu}^{*}=0.46-0.75\right)$, and flat-shaped MREE-HREE $\left([\mathrm{Dy} / \mathrm{Yb}]_{\mathrm{N}}=0.9-1.4\right)$.

Whole-rock isotopes and Hf isotopes in zircon exhibit a more juvenile character compared with the others plutons. $\varepsilon_{\mathrm{Nd}(\mathrm{i})}$ ranges from +2.4 to +4.6 , and $\varepsilon_{\mathrm{Hf}(\mathrm{i})}$ ranges from +7.3 to +10.6 . Hf isotopes in zircon yield $\varepsilon_{\mathrm{Hf}(\mathrm{i})}$ values from +5.9 to +12.2 . ${ }^{206} \mathrm{~Pb} /{ }^{204} \mathrm{~Pb}$ ratios range from 18.70 to $18.84,{ }^{208} \mathrm{~Pb} /{ }^{204} \mathrm{~Pb}$ ratios range from 38.37 to 38.56 , and the ${ }^{207} \mathrm{~Pb} /{ }^{204} \mathrm{~Pb}$ ratio is $\sim 15.61$. 


\subsection{DISCUSSION}

\subsubsection{Age distribution of the Jurassic-Early Cretaceous magmatic activity}

Our new U-Pb crystallization ages span from 165 to 129 Ma with no latitudinal or longitudinal trends in age distribution, which suggests a stationary arc that was active for ca. $40 \mathrm{Ma}$. Although the ages obtained in the Ibagué Batholith are within the 152 to $142 \mathrm{Ma}$ interval, older $\mathrm{U}-\mathrm{Pb}$ zircon crystallization ages ranging from 190 to $160 \mathrm{Ma}$ have been documented south of the Ibagué fault (Bustamante et al., 2010; Villagómez et al., 2011). Other Jurassic plutons with crystallization ages between 187 and $154 \mathrm{Ma}$ are exposed in the Sierra Nevada de Santa Marta (Tschanz et al., 1974; Leal-Mejía, 2011), the Santander massif (Mantilla-Figueroa et al., 2013; Van der Lelij et al., 2015), the San Lucas range (Leal-Mejía, 2011; Álvarez-Galindez, 2013; Cochrane, 2014a), and the Mocoa Batholith (Aspden et al., 1987), as well as minor plutons and stocks such as the Altamira, Garzón and Las Minas in southern Colombia (Bustamante et al., 2010). Thus, the available geochronological data, including our results, suggests that the Jurassic magmatism in the Colombian Andes extends from 200 to $129 \mathrm{Ma}$ (Fig. 3.10), which is at least $20 \mathrm{Ma}$ longer than the previous age compilations of Aspden et al. (1987) and Villagómez et al. (2011). In the Central Cordillera, the age distribution suggests that the magmatic activity was continuous for almost $60 \mathrm{Ma}$. The Jurassic magmatism can be followed further south to Ecuador, where zircon $\mathrm{U}-\mathrm{Pb}$ ages ranging from 190 to $145 \mathrm{Ma}$ have been documented in the Abitagua, Azafran, Zamora and Rosa Florida Batholiths (Noble et al., 1997; Chiaradia et al., 2009; Villagómez et al., 2011; Cochrane et al., 2014a; Spikings et al., 2015). 

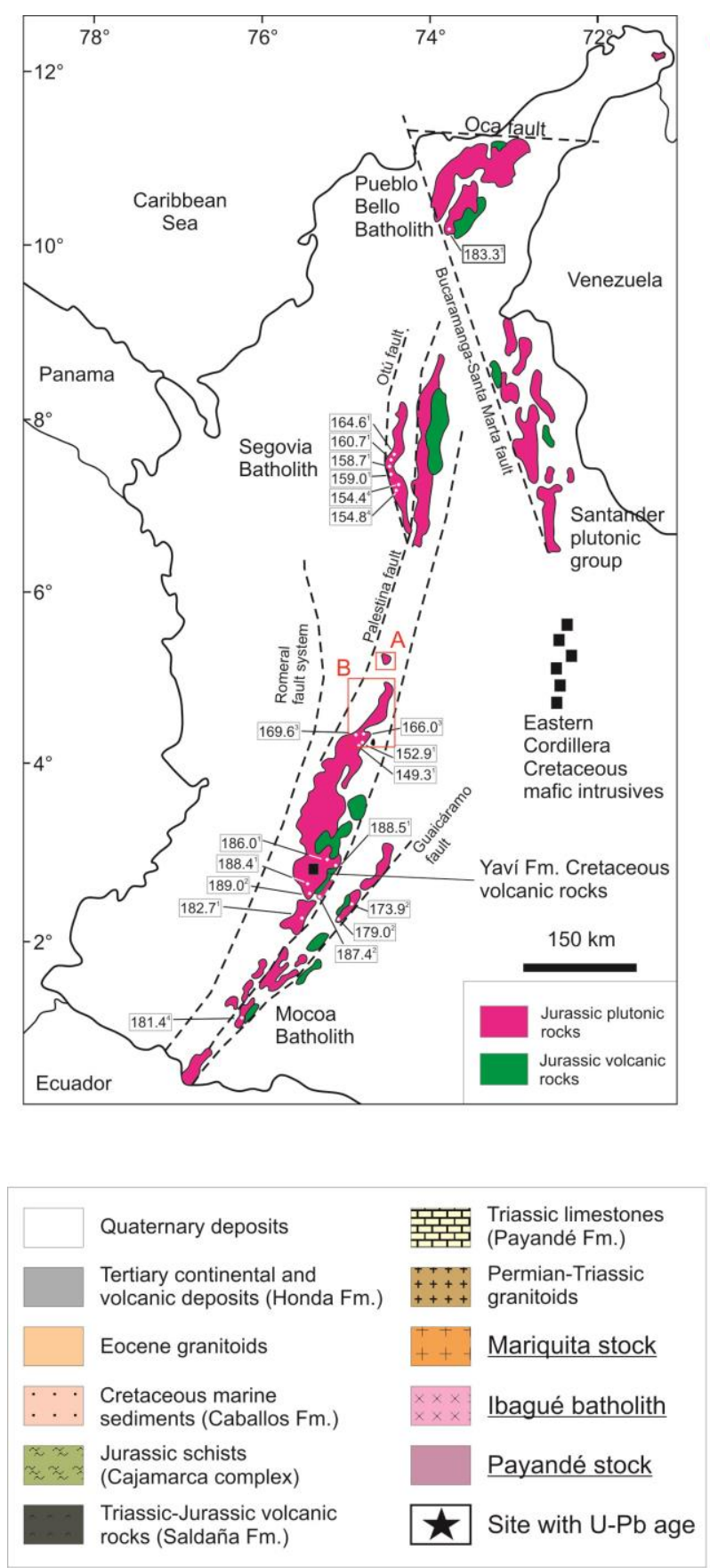
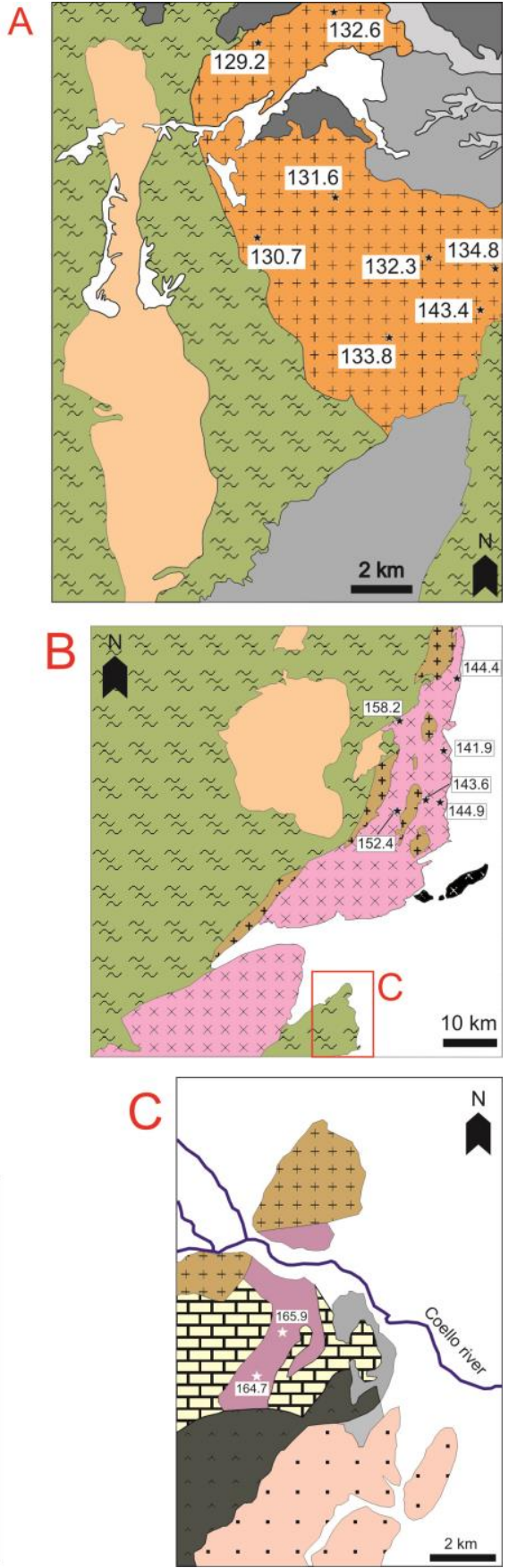

Figure 3.10. Map from Colombia showing the distribution of the Jurassic-Cretaceous magmatic belt. U-Pb zircon ages from this study and other works are plotted in rectangles. 1: Leal-Mejía (2011); 2: Bustamante et al. (2010); 3: Villagómez et al. (2011); 4: Álvarez-Galíndez (2013). Lower to mid-Cretaceous mafic magmatism is represented by white (Yavi Fm.: Toro-Toro et al., 2011) and black (Eastern Cordillera: Vásquez and Altenberger, 2005) squares.

This stationary arc model supported by the distribution of crystallization ages of the Jurassic plutonic rocks, also present several lines of evidence that suggest that the magmatic activity apparently decreased in volume between $200 \mathrm{Ma}$ and $129 \mathrm{Ma}$. This is indicated by the areal expression of the Jurassic to Early Cretaceous magmatic rocks, with a major reduction of the plutonic activity occurring after $170 \mathrm{Ma}$. The younger plutonic rocks have smaller 
areas, such as in the northern part of the Ibagué Batholith and in the Payandé and Mariquita stocks. Geochronology from volcanic rocks also suggest a similar trend, such as the larger Early Jurassic volcanism of the Saldaña Formation (Bayona et al., 1994; Zapata et al., 2016) compared with the limited Late Jurassic to Early Cretaceous volcanic products of the Yaví Formation (Toro-Toro et al., 2011). Likewise, detrital zircon from post-Jurassic sedimentary strata in the Magdalena and eastern Colombian Basins also show a significant decrease in the supply of Early Cretaceous zircon grains compared with Late Jurassic zircon, which may indicate reduced Cretaceous source areas available for erosion (Fig. 3.11; Nie et al., 2010; Horton et al., 2010; Saylor et al., 2011; Bayona et al., 2013; Caballero et al., 2013; Silva et al., 2013).

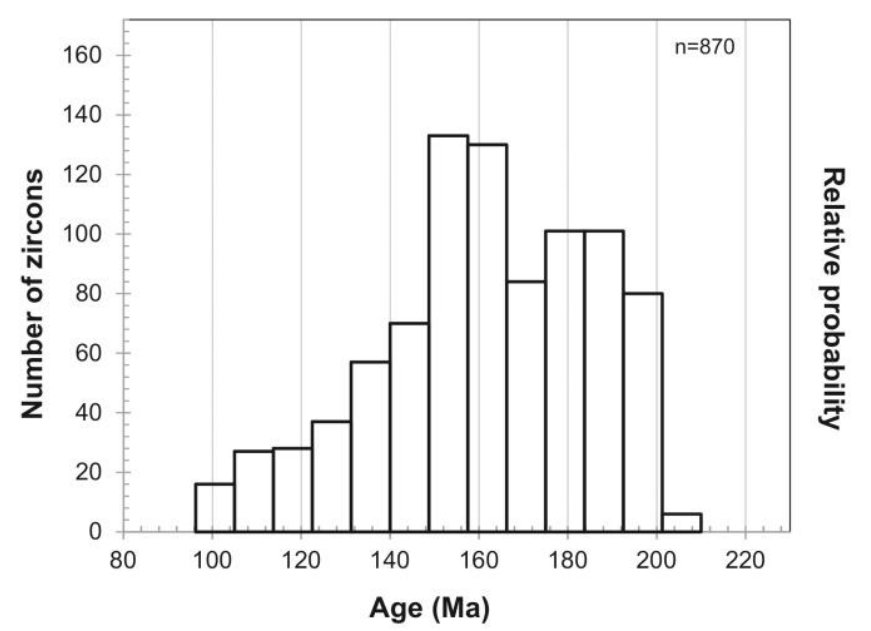

Figure 3.11. Detrital U-Pb zircon ages from boreholes showing that the density of ages is higher for the Lower to Middle Jurassic and decreases towards the Upper Jurassic to Lower Cretaceous, which is consistent with a decreasing volume of magma. Data are compiled from Nie et al. (2010), Horton et al. (2010), Saylor et al. (2011), Bayona et al. (2013), Caballero et al. (2013) and Silva et al. (2013).

\subsubsection{Genesis of the Mesozoic magmatic arc of the Central Cordillera}

Geochemical results of the Middle Jurassic (Payandé stock, c. $165 \mathrm{Ma}$ ), the northern segment of the Ibagué Batholith (c. 158-142 Ma), and the Lower Cretaceous (Mariquita stock, ca. 143-129 Ma) plutonic rocks, indicate a limited variation in the LREE/HREE ratios (Fig. 3.12) and in the alkalis content $\left(\mathrm{K}_{2} \mathrm{O}\right.$ and $\left.\mathrm{Na}_{2} \mathrm{O}\right)$ over time. Trace-element patterns, combined with the negative $\mathrm{Nb}$ and $\mathrm{Ti}$ anomalies, suggest a volcanic-arc setting, which is also confirmed by the tectonic discrimination diagrams (Fig. 3.13; Harris et al., 1986). The distinctive depletion in HFSE and LILE enrichment, along with the widespread presence of Ca-amphibole and sphene in Jurassic and Cretaceous rocks, suggests a significant input of volatile aqueous contents in the melt, as expected in a subduction setting (Best, 2003). 


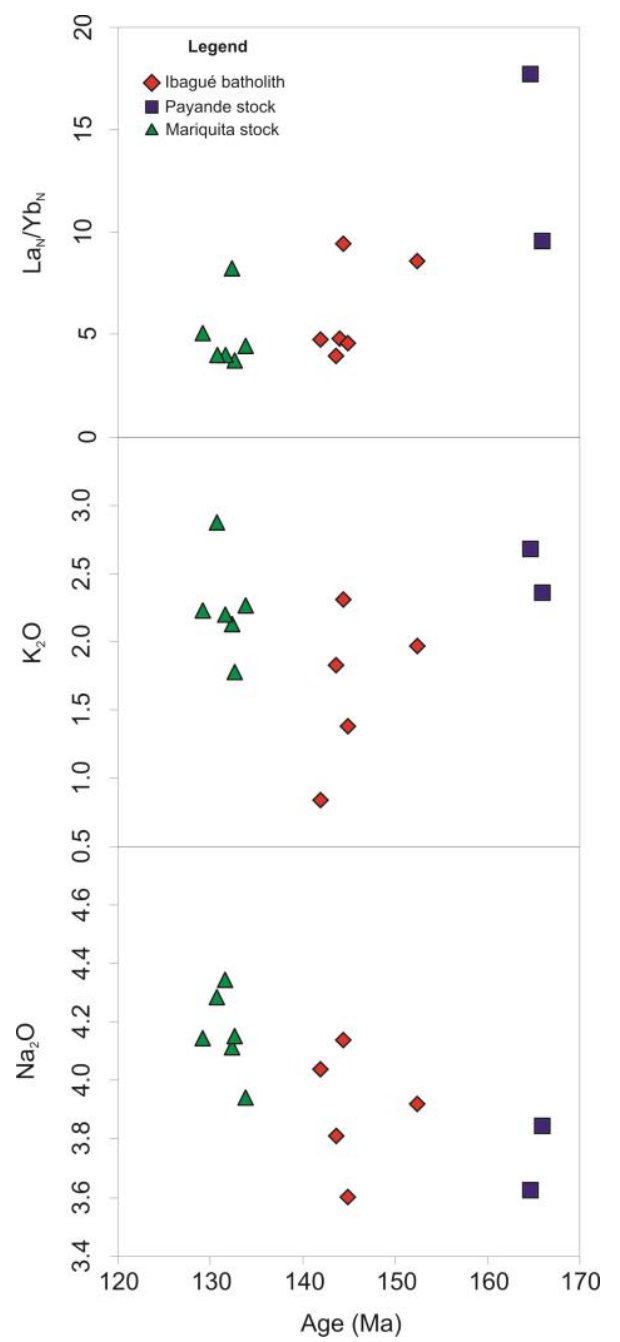

Figure 3.12. LREE/HREE ratios and alkalis content $\left(\mathrm{K}_{2} \mathrm{O}\right.$ and $\left.\mathrm{Na}_{2} \mathrm{O}\right)$ over time.

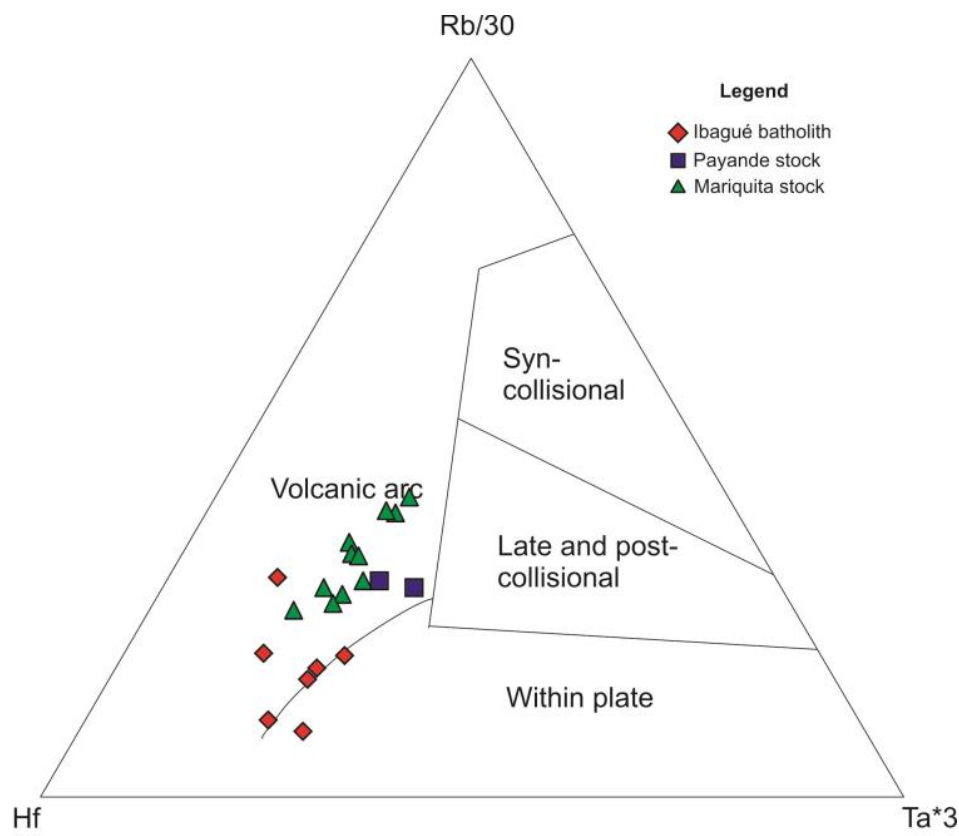

Figure 3.13. Discrimination diagram of granites (Hf-Rb/30-Ta*30) according to Harris et al. (1986). 
Lead isotopes show a linear array in ${ }^{207} \mathrm{~Pb} /{ }^{204} \mathrm{~Pb}$ vs ${ }^{206} \mathrm{~Pb} /{ }^{204} \mathrm{~Pb}$ (Fig. 3.14), in agreement with similar lead isotope studies documented in other plutons of the Central Cordillera (Leal-Mejía, 2011). ${ }^{207} \mathrm{~Pb} /{ }^{204} \mathrm{~Pb}$ values ranging from 15.59 to 15.62 are almost constant for the Payandé and Mariquita stocks, as well in the northern part of the Ibagué Batholith. These values fall along the orogenic curve of the plumbotectonic model (Fig. 3.14) of Zartman and Doe (1981), which suggests mixed lead sources. ${ }^{208} \mathrm{~Pb} /{ }^{204} \mathrm{~Pb}$ ratios have more scattered values ranging between 38.28 and 39.10, but they still form a linear array that matches both the upper crust and orogenic curves in the plumbotectonic model (Zartman and Doe, 1981). A remarkable feature of lead isotope data is that there is limited variation in the $\mathrm{Pb}$ isotope ratios, which suggests that the $\mathrm{Pb}$ from the three plutons comes from the same crustal source.

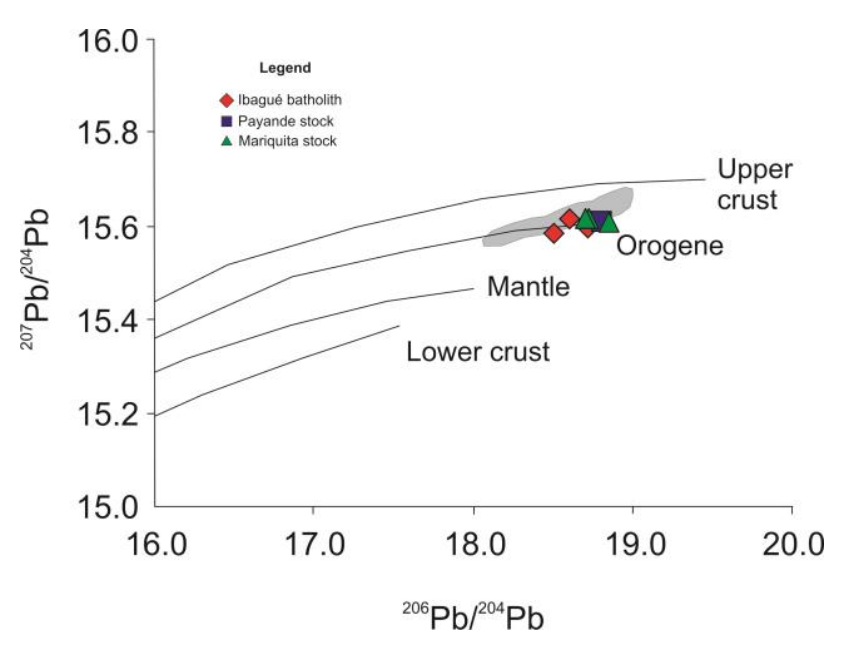

Figure 3.14. Lead isotopic evolution curve according to the plumbotectonics model of Zartman and Doe (1981).

$\mathrm{Hf}$ and $\mathrm{Nd}$ isotope data indicate an increasing juvenile character from the older to the younger plutons. This is observed in the negative correlation between initial $\varepsilon_{\mathrm{Hf}}$ and ${ }^{176} \mathrm{Hf} /{ }^{177} \mathrm{Hf}$ in the zircon and whole-rock geochemical data compared with ${ }^{206} \mathrm{~Pb} /{ }^{238} \mathrm{U}$ crystallization ages (Fig. 3.15). Similar results were obtained by Cochrane et al. (2014a) in their study of magmatic rocks of Colombia and Ecuador. Despite this increasing juvenile trend with time, the comparison of initial $\varepsilon_{\mathrm{Hf}}$ vs. $\varepsilon_{\mathrm{Nd}}$ reveals differences between zircon and whole-rock data, with whole-rock data plotting at slightly more radiogenic values than the corresponding zircon with a few exceptions from the Mariquita stock (Fig. 3.16). This suggests that the Hf isotope ratios of zircon record an important sedimentary input that is not detected in the ${ }^{206} \mathrm{~Pb} /{ }^{238} \mathrm{U}$ ages (Figs. 3-5) or in other whole-rock isotopic values (Fig. 3.15 and 16). Clearly, the sample of the Payandé stock (CSP5), which shows both whole-rock and 
zircon data below the terrestrial array, has a sedimentary contamination of its source. The Ibagué Batholith samples also show that some clastic material is entraining by subduction and thus contaminating its mantle source. This behavior is similar to a sample of the Mariquita stock (CM19) in that whole-rock $\mathrm{Hf}$ and $\mathrm{Nd}$ values plot above the mantle array and the $\varepsilon_{\mathrm{Hf}}$ in zircon plot below it. This probably indicates a clastic source of contamination similar to that for the Ibagué Batholith. In Sample CM4, in contrast, the majority of Hf values in zircon and whole-rock data are situated above the mantle array (Fig. 3.16), indicating minor clastic sediment contamination. Although no zircon grains were analyzed in samples CI7 (Ibagué Batholith) and CM8 (Mariquita stock), their whole-rock $\varepsilon_{\mathrm{Hf}}$ and $\varepsilon_{\mathrm{Nd}}$ values, which plot above the mantle array, possibly indicate that the magmas were derived from a pelitic source.
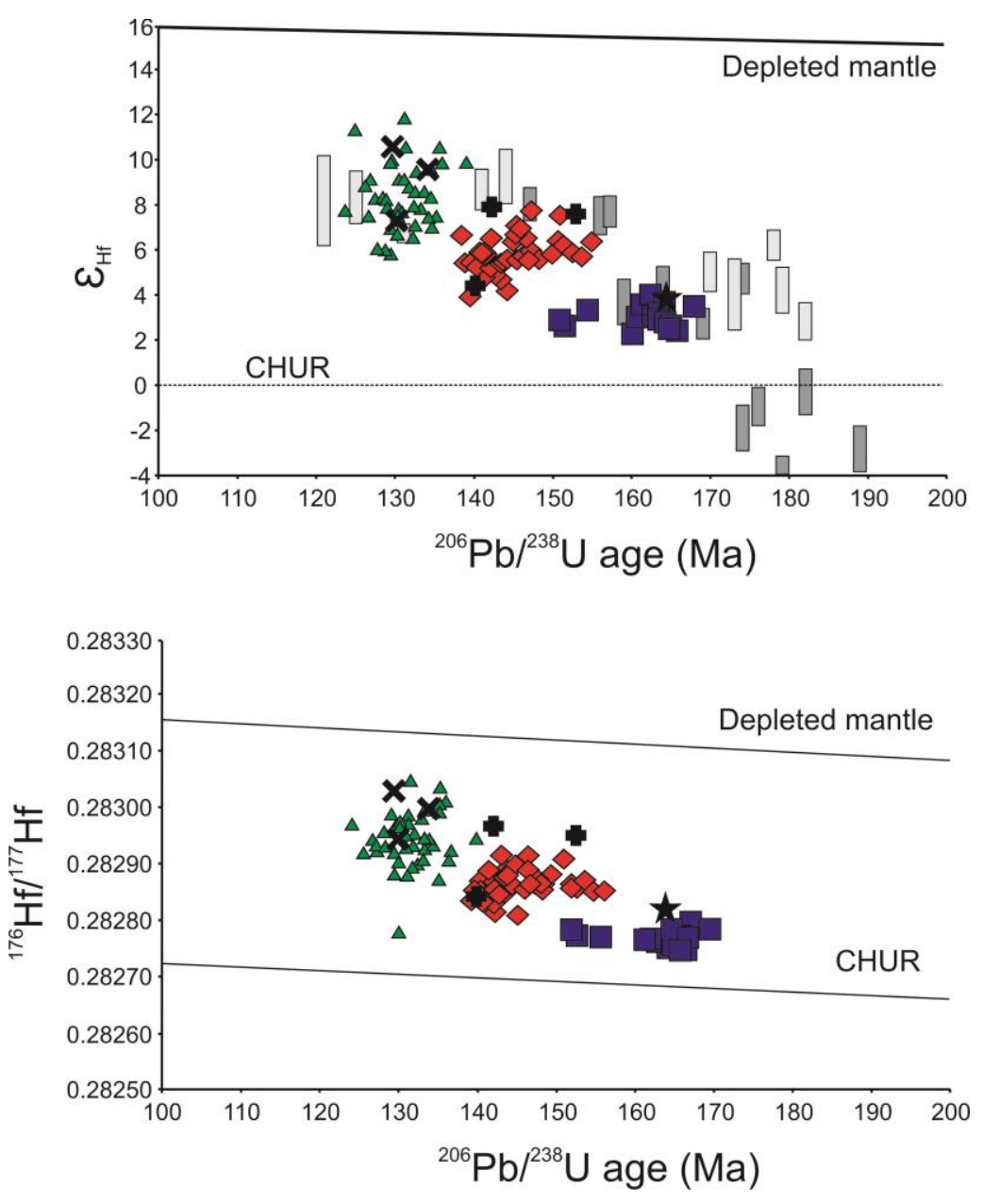

Figure 3.15. Variation of initial $\varepsilon_{\mathrm{Hf}}$ and ${ }^{176} \mathrm{Hf} /{ }^{177} \mathrm{Hf}$ in zircon and whole rock with ${ }^{206} \mathrm{~Pb} /{ }^{238} \mathrm{U}$ crystallization age. Triangles and rotated crosses: Mariquita stock zircon and whole-rock data, respectively; Diamonds and crosses: Ibagué Batholith zircon and whole-rock data, respectively; Squares and star: Payandé stock zircon and whole-rock data, respectively; Dark grey rectangles: data from Colombian granites (Cochrane et al., 2014a); Light grey rectangles: data from Ecuadorian granites (Cochrane et al., 2014a). 


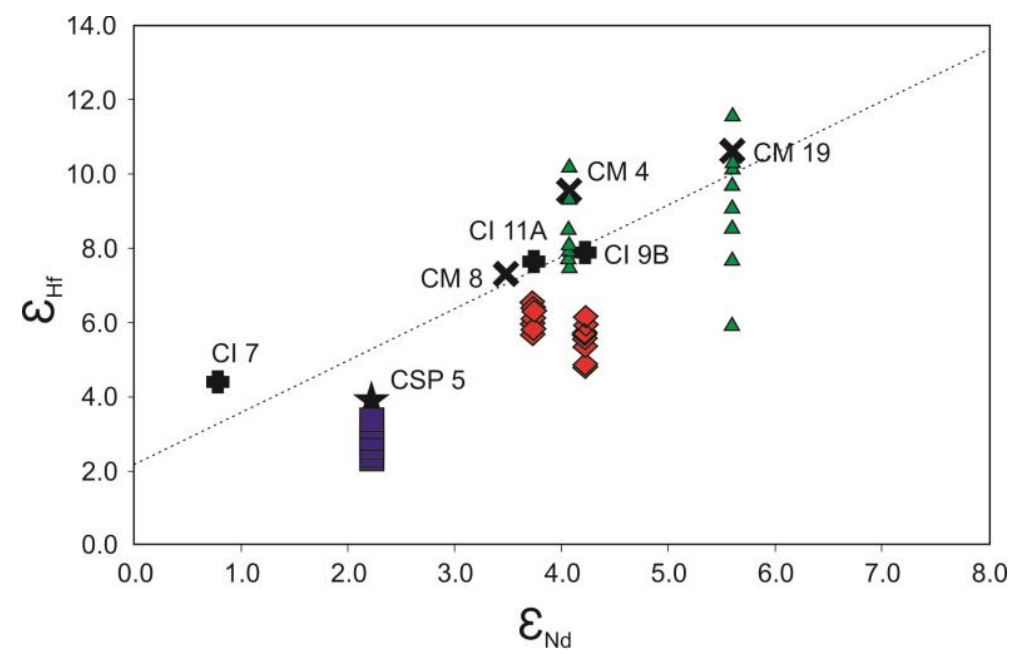

Figure 3.16. Initial $\varepsilon_{\mathrm{Hf}}$ vs. $\varepsilon_{\mathrm{Nd}}$ diagram. Symbols same as in fig. 13. Hf-Nd mantle array from Vervoort and Blichert-Toft (1999).

The temporal trend observed in the isotopic fingerprints of the Jurassic magmatism is related to the behavior of the subduction setting trough time. Slab roll-back have been considered as a potential mechanism that also controls the extensional tectonic on the margin (Leal-Mejía, 2011; Cochrane et al., 2014a; Spikings et al., 2015). This mechanism can also provide a progressive addition of juvenile material to the crust (Kemp et al., 2009) that, combined with a rapid upward migration of the magma, may prevent significant contamination of the magma with the continental crust, resulting in the $\mathrm{Hf}$ and $\mathrm{Nd}$ isotopic evolution previously described.

However, the roll-back model is faced with some issues, such as (1) the unreliability of the westward migration of magmatism (Leal-Mejía, 2011; Cochrane et al., 2014a; Spikings et al., 2015) and (2) the decreasing magmatic activity after c. 165 until the Early Cretaceous. Regarding the age distribution of the magmatic rocks, we note that the Payandé stock is located to the east of the older granitoids of the southern part of the Ibagué Batholith. Furthermore, when all published geochronologic results are taken into account (e.g., Bustamante et al. 2010), we see no clear east or west age migration in the time interval between $190 \mathrm{Ma}$ and $129 \mathrm{Ma}$.

We suggest the following alternative models to explain the compositional (juvenile trend) and spatial features such as the reduction of the magmatic products in the study area: 1. A two-stage melting model, where early mantle-derived basaltic magmas are emplaced in the lower crust and are re-melted by mantle heat input to yield intermediate to felsic magmas (Annen and Sparks, 2002; Annen et al., 2006). 
2. Continuous melting of subducted mélanges, consisting of basalt and sediments, and subsequent transport of molten material as silicic diapirs into the mantle wedge. Further fractionation will form granodioritic melts, leaving a granulite residue in the source (Vogt et al., 2013; Castro et al., 2013).

The former process implies a long-term evolution of the arc system in that the recurrent mafic underplating of the lower crust would provide melts less contaminated by crustal rocks through time (and consequently more juvenile). Although this scenario has been suggested for the evolution of other magmatic arcs (Pankhurst et al., 1999; Hervé et al., 2007), it does not consider the continental radiogenic input transferred by subducted sediments that was identified in the isotopic analysis.

Recent numerical and experimental models predict the melting of subducted mélanges (basalt + sediments) and subsequent transport of molten material as silicic diapirs into the mantle wedge (Vogt et al., 2013; Castro et al., 2013). The emplacement of these diapirs at crustal levels is caused by relamination when melt extraction from the diapir weakens the lithosphere assisting its ascent (Hacker et al., 2011; Behn et al., 2011; Castro, 2014). Further partial melting of the diapirs produces granodiorite liquids and mafic granulite residues. Geochemical and isotopic characteristics of the liquid will depend on the rates of basalt and sediment melting (source) and will not reflect any changes in major element compositions, whereas the isotopic signature will evolve towards a more primitive composition (Vogt et al., 2013).

Within the scenario where the $\mathrm{Na} 2 \mathrm{O}, \mathrm{K}_{2} \mathrm{O}$ and $\mathrm{La}_{\mathrm{N}} / \mathrm{Yb}_{\mathrm{N}}$ composition is preserved (Fig. 3.12), the rocks became isotopically more juvenile through time (Vogt et al., 2013). This isotope evolution is associated with a hybrid source composed by melting of basalt and sediment, where an increase in the basaltic component and a decrease in sediment will move the isotopic ratios to more radiogenic isotope compositions (more positive epsilon $\mathrm{Nd}$ and $\mathrm{Hf}$ values). As a consequence, the major element composition will remain unaffected since it is dependent on the temperature of melting rather than the source composition, as demonstrated by the experimental work of Castro et al. (2010). The melting of the sedimentary components will yield magmas that consequently end up in a diapir, which will be more refractory, and magma volumes will also decrease as a result (Fig. 3.17). 


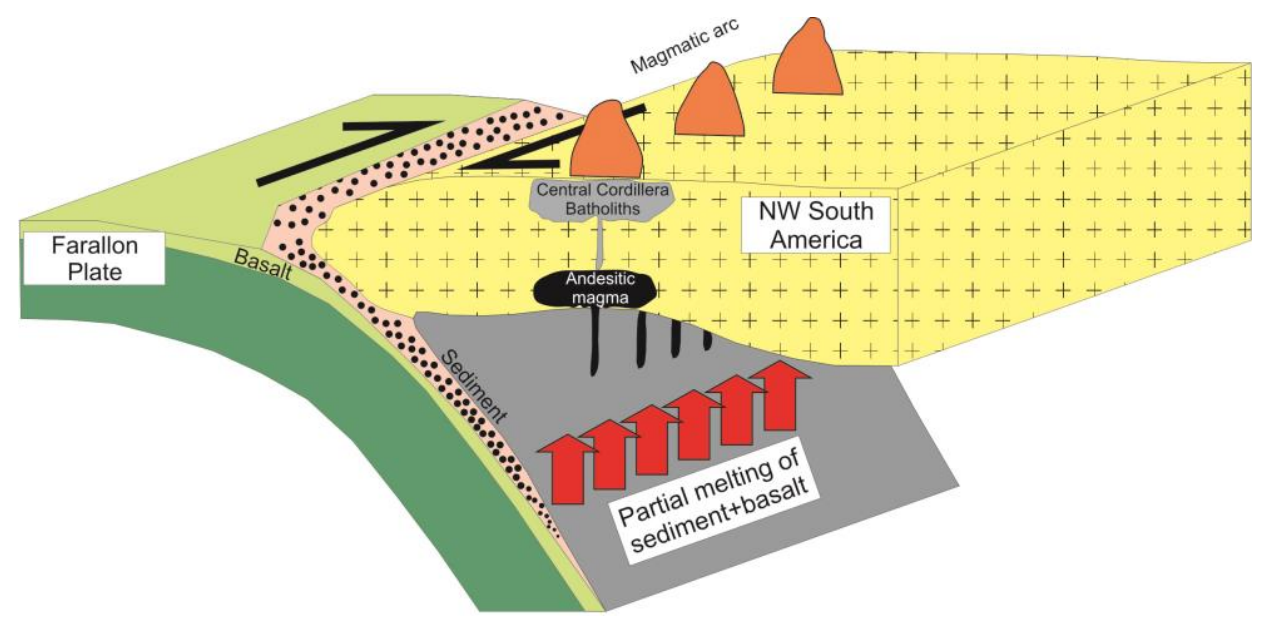

Figure 3.17. Model proposed (not to scale) for the generation of the Early Jurassic to Early Cretaceous magmatic arc in the Northern Andes of Colombia. The figure shows the relationship between oblique convergence, clastic input, and basalt+sediment melting of the crust to form granodioritic batholiths (modified from Castro, 2014).

We therefore suggest that the model of melting of a subducted mélange seems more plausible than the lower crustal emplacement of basaltic magmas because the latter does not fit with the juvenile trend recorded in the isotopic values of the studied rocks.

The decrease in magmatic activity after ca. $145 \mathrm{Ma}$ is significant in Colombia (Villagómez et al., 2011; Cochrane et al., 2014a) and Ecuador (Chiaradia et al., 2009). Several mechanism have been proposed to explain the absence of magmatic activity in convergent margins, including shallowing of the subduction angle, changes in convergence rate or removal of the fusible components of the magmatic source (Jarrard, 1986; Glazner, 1991; Ducea, 2001; Sagong et al., 2005; Gorczyk et al., 2007; Hervé et al., 2007). Shallowing of the slab is not considered to be a viable mechanism in this case because it is accompanied by broadening of the arc and compressional tectonic events (Ramos, 2009). Such a process is not observed in the margin, which is instead characterized by extensional deformation (Sarmiento-Rojas et al., 2006). Slow convergence is commonly associated with an increase in magma production in a subduction margin. Paleotectonic reconstructions for the Andes have shown that the convergence rate between 140 and 130 Ma slowed down (Maloney et al., 2013). However, as already discussed, igneous productivity also seems to have decreased over this interval.

Stratigraphic and paleomagnetic constraints suggest that the continental margin of the northern Andes is characterized by prominent extensional tectonics and lateral displacement of terranes (Bayona et al., 2006, 2010; Sarmiento-Rojas et al., 2006). Moreover, tectonic reconstructions have shown that the plate margin may have had a significant south to north convergence vector in the Late Jurassic (Seton et al., 2012). This change in the upper plate 
configuration is related to a major change in the convergence obliquity (Fig. 3.17), resulting in a magmatic arc controlled by transtensional strains. In this scenario, the amount of sediment entering the subduction channel becomes minor because they are preferentially transported along a trench (Malatesta et al., 2013); consequently reducing the water content that reaches the mantle wedge. This model, together with the aforementioned refractory behavior of the source mélange, which probably has already removed the most fusible components, represents the major controls of arc evolution in the northern Andes.

\subsubsection{Jurassic tectonomagmatic evolution of the Northern Andes}

We now integrate the characteristics of the aforementioned magmatic interval with the older Jurassic record, which includes the southern segment of the Ibagué Batholith along with the plutonic rocks from the Garzón Massif and the Mocoa Batholith further south.

During the Permo-Triassic, the Central Cordillera and the Cordillera Real of Colombia and Ecuador experienced the last phases of the agglomeration of Pangea and the beginning of its break-up, which is reflected in a bimodal S-type and gabbroic syn-tectonic magmatism (Vinasco et al., 2006; Restrepo et al., 2011; Cochrane et al., 2014b; Martens et al., 2014). Following this event, there is an apparent magmatic and tectonic quiescence, reflected in the formation of significant carbonate platforms until the Late Triassic to Early Jurassic (Cediel et al., 2003; Ramos, 2009), until subduction resumes in the Early Jurassic (Ramos, 2009; Vásquez et al., 2009).

During the earlier phases of subduction, voluminous I-type magmatism took place, as suggested by the presence of large $200 \mathrm{Ma}$ to $170 \mathrm{Ma}$ plutons in the Northern Andes. These magmatic bodies are characterized by a more radiogenic signature compared with the younger rocks (Leal-Mejía, 2011; Cochrane et al., 2014a). Major extensional basins were also formed within the margin during this time interval (Sarmiento-Rojas et al., 2006). These events may reflect the presence of a steeper subduction (Gorczyk et al., 2007) and probably the existence of a slab roll-back mechanism (Cochrane et al., 2014a). This earlier magmatic phase was replaced by changes in magmatic volumes and the formation of an oblique margin with a strong decrease in magma production until ca. $110 \mathrm{Ma}$ (Villagómez et al., 2011). A Jurassic collision-related metamorphic event between $158 \mathrm{Ma}$ and $147 \mathrm{Ma}$ immediately to the west of the northern segment of the Ibagué Batholith took place (Blanco-Quintero et al., 2014). This event overlaps in time with the formation of the studied plutonic rocks that do not show signs of syn-tectonic intrusion. Therefore, following Blanco-Quintero et al. (2014), this event may 
have taken place in an allochthonous position and may reflect along-strike segmentation of the Jurassic margin in an oblique regime where transpression and transtension behavior are distributed along the margin. As oblique convergence continues and the subducted hybrid mélange (Castro et al., 2013) is melted losing the sedimentary input and increasing the basaltic and serpentinite signature, arc magmatism become isotopically more juvenile and refractory. As convergence become more oblique the formation of new mélanges and fluid flow in the mantle wedge is also reduced (Hoernle et al., 2008; Malatesta et al., 2013; Rooney et al., 2015) contributing to the reduction in the magmatic products seen in the Late Jurassic to Early Cretaceous arc.

The discussed tectonomagmatic model involves Jurassic magmatic units that are spatially related along the Central Cordillera and Upper Magdalena Valley, and represent a long termed evolution of a stationary arc. Nevertheless, we are aware that the correlation with other Jurassic segments of the Northern Andes must be viewed with caution because several Mesozoic domains appear to have paleomagnetic signatures of south to north terrane transfer (Bayona et al., 2006; 2010), which might have translated different blocks, masking their original tectonic relations and leading to misinterpretations. However, even if an allochthonous or autochthonous view is followed (Bayona et al., 2006; Spikings et al., 2015), the discussed tectonomagmatic controls seem to be a characteristic of the Northern Andes of Colombia and Ecuador.

\subsection{CONCLUSIONS}

The integration of new petrographic, geochronological, geochemical, and isotopic results from magmatic rocks of the Central Cordillera and Upper Magdalena valley indicate magmatism in a stationary arc between $165 \mathrm{Ma}$ and $129 \mathrm{Ma}$. This magmatism is characterized by an increase in the isotopic $\varepsilon_{\mathrm{Nd}(\mathrm{i})}$ and $\varepsilon_{\mathrm{Hf}(\mathrm{i})}$ values that can be related to the evolution of the source area over time. Possible scenarios for the long-term evolution of the magmas include: (1) compositional changes in the lower crust, in which the older crust is replaced by basaltic magmas that are subsequently melted; and (2) a cold plume basalt+sediment diapir that involves the replacement of radiogenic sedimentary inputs towards more juvenile basaltic and mantle sources. However, the second model, when combined with changes in convergence obliquity, is able to explain the progressive reduction in magmatic activity until it eventually ceases between $129 \mathrm{Ma}$ and $110 \mathrm{Ma}$. The integrated results indicates that the Northern Andes experienced very high magmatic productivity between $200 \mathrm{Ma}$ and $170 \mathrm{Ma}$ but that ceased 
completely in the Early Cretaceous probably with the reduction of fusible components transported by the subduction zone into the mantle.

It is therefore suggested that the long-term evolution of stationary continental arcs is characterized by an increase in its juvenile character and decrease in the volume as its source become more depleted and refractory trough time, which is also expected to be a cyclic process. More regional scale tectonic controls such as steepening of the subduction angle with associated roll-back or changes in convergence obliquity may also influence the compositional, spatial distribution and volumes of the magmatic productivity of arcs, and therefore suggest that the reconstruction of feasible magmatic arc models requires a detailed field, compositional and geochronological approach. 


\title{
Capítulo 4
}

\section{Geochemistry and isotopic signatures of Paleogene plutonic and detrital rocks of the Northern Andes of Colombia: a record of post-collisional arc magmatism ${ }^{3}$}

\begin{abstract}
The northern Andes have experienced overimposed processes of subduction and collision associated with the convergence against the Caribbean Plate. Since the end of the Mesozoic, these processes have been recorded in the formation of Late Cretaceous to Eocene plutonic rocks in the Central Cordillera of the Colombian Andes. In this contribution the magmatic evolution and tectonic relation of selected Paleogene plutons is analyzed by means of integrated geochronological, geochemical and isotopical constraints. U-Pb zircon crystallization ages from representative Paleocene-Lower Eocene plutonic rocks (tonalites and granodiorites) shows that this magmatism is characterized by crystallization ages between 60 $\mathrm{Ma}$ and $53 \mathrm{Ma}$, whereas $\varepsilon_{\mathrm{Hf}(\mathrm{i})}$ values range between -4 and $+7, \mathrm{Nb}$ and Ti negative anomalies, a high LREE/HREE and $\mathrm{Sr} / \mathrm{Y}>28$ ratios are consistent with a continental magmatic arc setting. $\mathrm{Sr}, \mathrm{Nd}$ and $\mathrm{Pb}$ relatively low radiogenic isotopes from selected samples account for an heterogeneous crustal source.

It is proposed that this Paleocene to Eocene arc rocks of relatively limited areal expression when compared with older Mesozoic arc rocks, were affected by high pressure differentiation at the garnet stability field as indicated in the high $\mathrm{Sr} / \mathrm{Y}$ ratios. When evaluated trough time the continental crust shows evidences of crustal thickening as a consequence of the former Mesozoic subduction and arc-continent collisional history. Ages and Hf isotopes from detrital zircon extracted from volcanoclastic rocks of eastern Colombia re-enforced the possibility of a distal magmatic focus. It would have formed due to mantle flow in the inherited Mesozoic extensional structures, as the subduction of the Caribbean oceanic slab was active during the Paleogene after the arc-continent collisional event.
\end{abstract}

\footnotetext{
3 Bustamante, C., Cardona, A., Archanjo, C., Bayona, G., Lara, M., Valencia, V. 2016. Geochemistry and isotopic signatures of Paleogene plutonic and detrital rocks of the Northern Andes of Colombia: a record of postcollisional arc magmatism. Lithos.
} 


\subsection{INTRODUCTION}

The Late Cretaceous to Paleogene tectonic evolution of the northern Andes has been related to the initial collision and subsequent subduction of the buoyant Caribbean oceanic plate under the northwestern South American margin (Kerr et al., 1997; Pindell and Kennan, 2009; Spikings et al., 2001, 2005, 2015; Luzieux et al., 2006; Vallejo et al., 2006; Villagómez et. al., 2011; Bayona et al., 2011; Cardona et al., 2011a). Vestiges of such settings are found in a series of intrusive rocks in both the Central and Western Cordilleras of the Colombian Andes (Aspden et al., 1987; Villagómez et al., 2011; Bayona et al., 2012), together with immature volcanoclastic sandstones and tuffs in the Eastern Cordillera and Llanos basin as far as ca. 400 km inland (Fig. 4.1A; Bayona et al., 2012).

The Paleocene to Eocene plutonic rocks of the Central Cordillera were formed after an island arc and plateau-continent collision. Also, they has been related to the new subduction of the Caribbean plate under the South American margin (Pindell et al., 2005; Cardona et al., 2011b; Villagomez et al., 2011; Bayona et al., 2012). However, their precise origin and its role as a record of collisional to subduction tectonics have not been fully explored. This is because geochemical data is still limited and the age constraints are based only on K-Ar data which represent cooling instead of crystallization ages (see Aspden et al., 1987 for a review) or limited U-Pb zircon ages (Leal-Mejía, 2011; Bayona et al., 2012).

In this contribution, we present new U-Pb magmatic zircon crystallization ages, whole rock geochemistry and $\mathrm{Sr}-\mathrm{Nd}-\mathrm{Pb}$ and $\mathrm{Hf}$ isotopes on magmatic and detrital rocks to investigate the origin of Paleogene magmatism of the Colombian Andes. We propose a tectonic setting in which melting and differentiation of mafic and sialic crust occurred at high pressures in a lower continental crust (Chiaradia, 2015; Chapman et al., 2015). That crust was underplated tectonically and magmatically during Late Cretaceous and Paleocene arccontinent collisional event (Cardona et al., 2011b; Villagómez et al., 2011; Bayona et al., 2012; Spikings et al., 2015). The inherited tectonic evolution of a margin, in turn, can influence the composition and spatial distribution of the overimposed magmatic rocks.

\subsection{GEOLOGICAL SETTING}

The Andean range in Colombia is divided into three different Cordilleras separated by major river valleys (Fig. 4.1 A, B): (i) the Western Cordillera, which includes Cretaceous oceanic rocks, was accreted during the Late Cretaceous to Early Paleogene migration and collision of the Caribbean plate against the northwestern South American margin (Nivia, 
1996; Spaeda and Espinosa, 1996; Kerr et al., 1997; Pindell and Kennan, 2009; Villagomez et al., 2011; Villagómez and Spikings, 2013; Spikings et al., 2015). (ii) The Central Cordillera is built over an extensive Paleozoic to Triassic metamorphic basement with associated S-type granitoids (Vinasco et al., 2006; Martens et al., 2014; Cochrane et al., 2014a). Late Cretaceous plutonic rocks formed between ca. 90 and 65 Ma (Aspden et al., 1987; IbañezMejia, 2007; Ordóñez-Carmona et al., 2008; Vinasco et al., 2006; Villagómez et al., 2011; Leal-Mejia et al., 2010) intrudes Jurassic metamorphic rocks (Blanco-Quintero et al., 2014; Bustamante et al., 2016). Its eastern flank includes an extensive series of arc-related Jurassic to Cretaceous plutonic and volcanic rocks (ca. 190 and 129 Ma) (Brook, 1984; Aspden et al., 1987; Sillitoe et al., 1982; Bayona et al., 1994; Cediel and Cáceres, 2000; Cediel et al., 2003; Vinasco, 2006; Villagómez et al., 2011; Leal-Mejia, 2011; Bustamante et al., 2010; 2016; Cochrane et al., 2014b). (iii) The Eastern Cordillera is formed by discontinuously exposed Proterozoic and Paleozoic metamorphic and sedimentary rocks. These are covered by thick deformed Mesozoic and Cenozoic sedimentary rocks of marine, transitional and continental environments. These deposits document the transition from extensional to compressional tectonics, and the subsequent Cenozoic deformation and uplift of the Eastern Cordillera (Villamil, 1999; Horton et al., 2010; Sarmiento-Rojas et al., 2006; Parra et al., 2012; Bayona et al., 2013). 


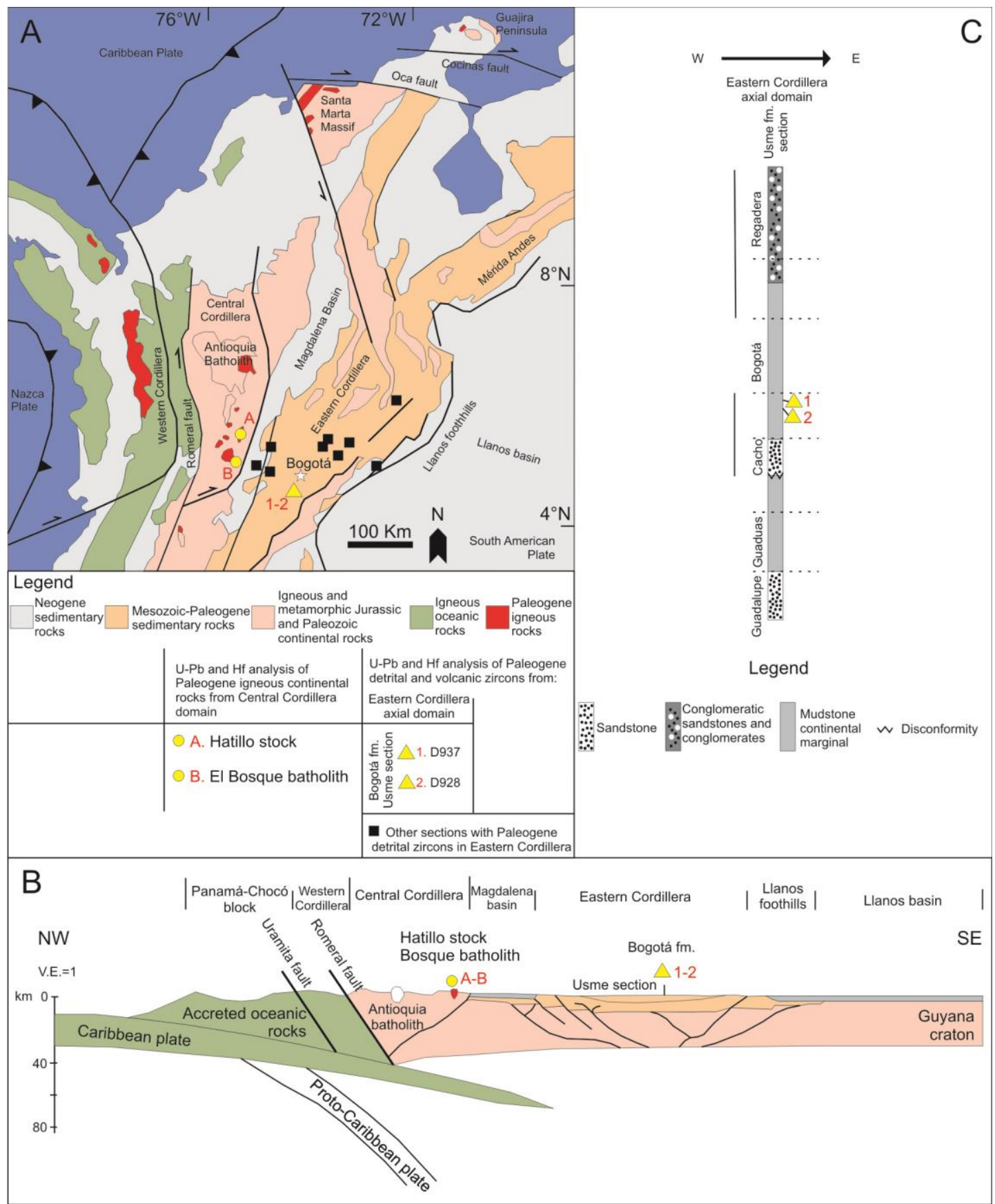

Figure 4.1. A. Location of Paleogene igneous bodies sampled in Western and Central Cordillera and Paleogene detrital zircons sampled in Eastern Cordillera of Colombia; B. Regional cross section of Central Colombia with Paleogene samples; C. Sedimentary section with detrital samples analyzed. Figure modified from Bayona et al. (2012).

\subsubsection{Paleogene magmatism in the Colombian Andes}

Paleogene arc-related magmatic bodies with crystallization ages between ca. 60 - 40 Ma are exposed in the Western Cordillera as bodies of batholithic (eg. Mandé and Acandí) to stock dimension intruding Upper Cretaceous oceanic volcano-sedimentary sequences (Aspden et al., 1987; Montes et al., 2015). Such rocks are considered as intra-oceanic arc related 
sequences accreted to the continental Panamá-Chocó block since the Miocene (Duque-Caro, 1990; Montes et al., 2015).

Within the Central Cordillera, outcrops several bodies of stock and batholitic sizes and mainly granodiorite to tonalite compositions, include Hatillo, Manizales, Norcasia, El Bosque, Sonsón and Santa Barbara plutons (Fig. 4.1), and some of the eastern facies of the Antioquia Batholith (Aspden et al., 1987; Leal-Mejía, 2011; Bayona et al., 2012). All of them intrude the Triassic and Jurassic metamorphic rocks of the Central Cordillera and are characterized by their smaller sizes when compared with the Jurassic and Cretaceous magmatic belt of the Central Cordillera, reaching mostly stock dimensions (Aspden et al., 1987). Plutonic rocks of the same age are also found in the Sierra Nevada de Santa Marta (Tschanz et al., 1969; Cardona et al., 2011a; 2011b) and the Jarara range of the Guajira Península (Fig. 4.1A). They include the Santa Marta batholith and the Parashi stock and intrude metamorphosed Cretaceous volcano-sedimentary sequences (Cardona et al., 2014).

Provenance studies including detrital zircon geochronology of siliciclastic deposits from Cesar-Rancheria basin in northern Colombia (Ayala-Calvo et al., 2009; Cardona et al., 2011a; Bayona et al., 2012), and the Eastern Cordillera basins (Bayona et al., 2012) show the presence of zircons with $\mathrm{U}-\mathrm{Pb}$ ages ranging between 65 and 45 Ma. They are interpreted asderived from the erosion of both distal and proximal magmatic centers. According to Bayona et al. (2012), the wide distribution of Paleogene detrital zircons and sedimentological characteristics of several tuffaceous levels indicate that their detritus would be supplied by nearby volcanic centers. Provenance analysis on sedimentary basins and available geochronological results from magmatic rocks have suggested that after 50-45 Ma magmatic activity ceased in the Northern Colombian Andes, until it resumed as a well-defined magmatic arc that started to growth at ca. $25 \mathrm{Ma}$ (Bayona et al., 2012; Echeverry et al., 2015; Montes et al., 2015).

\subsection{SAMPLING AND METHODS}

To understand the timing and processes that characterized the Paleogene magmatism of the Northern Andes, we sampled two Paleogene plutons, the Hatillo stock and the Bosque batholith (see location on Fig. 4.1), to investigate their whole rock geochemistry, Sr, $\mathrm{Nd}$ and $\mathrm{Pb}$ isotope compositions and $\mathrm{Hf}$ isotopes in zircons dated by $\mathrm{U}-\mathrm{Pb}$ method. Besides plutonic rocks, two samples from volcanoclastic sedimentary rocks of the Bogotá formation (Fig. 4.1) were investigated to determine the provenance of their zircons. These samples are the same as 
those studied by Bayona et al. (2012), in which Paleogene zircons were found. We combine the detrital zircon geochronology with $\mathrm{Hf}$ isotopes to check the origin of these crystals by comparing their signatures with zircons from plutonic rocks of the same age. $\mathrm{U}-\mathrm{Pb}$ ages from the detrital samples are those presented by Bayona et al (2012). Although our analysis will be concentrated in a local segment of the margin, we will integrate the new results with published geochemical constraints from other Paleogene and Cretaceous magmatic rocks of the Colombian Andes, in order to gain a regional perspective of the Early Paleogene evolution of the Northern Andean margin.

\subsubsection{Whole rock geochemistry}

Bulk whole rock chemical analysis of 14 samples (Table 4.1) were determined for the Hatillo stock (12 samples) and Bosque batholith (2 samples). The samples were crushed using jaw crusher and powdered using tungsten carbide ring mill. Major and trace elements were analyzed using a Rigaku 3370 XRF spectrometer at the Washington State University. Details of sample preparation, dilution and analytical procedure are described in Johnson et al. (1999). REE were determined by inductively coupled plasma-mass spectrometry (ICP-MS) at the Washington State University. A $2 \mathrm{~g}$ aliquot is weighed into a graphite crucible and mixed with $2 \mathrm{~g}$ of $\mathrm{LiBO}_{2}$ flux. The crucibles are placed in an oven and fused at $1000^{\circ} \mathrm{C}$ in a muffle furnace for 30 minutes. The resultant bead is ground in a steel ring mill and a $0.25 \mathrm{mg}$ portion is dissolved using $\mathrm{HNO}_{3}(2 \mathrm{ml}), \mathrm{HF}(6 \mathrm{ml})$ and $\mathrm{HClO}_{4}(2 \mathrm{ml})$ at $110^{\circ} \mathrm{C}$.

\subsubsection{Whole rock $\mathrm{Sr}$, $\mathrm{Nd}$ and $\mathrm{Pb}$ isotopes}

Analyses were acquired using a Thermo-Finnigan Neptune multicollector system at Washington State University and results are presented in Table 4.1. Procedures for sample preparation and dilution details for $\mathrm{Sr}, \mathrm{Nd}$, and $\mathrm{Pb}$ isotopes are those as in Gaschnig et al. (2011). Sr analyses were corrected for mass fractionation using ${ }^{86} \mathrm{Sr} /{ }^{88} \mathrm{Sr}=0.1194$ and normalized using NBS-987. Average reproducibility with 2 standard deviations of ${ }^{87} \mathrm{Sr} /{ }^{86} \mathrm{Sr}$ was \pm 0.00005 . Initial isotopic values were calculated using $\mathrm{Rb}$ and $\mathrm{Sr}$ concentrations from $\mathrm{XRF}$ for Sr isotopes. Sm and $\mathrm{Nd}$ were prepared by following the procedures described in Vervoort and Blichert-Toft (1999). Sm was corrected using ${ }^{147} \mathrm{Sm} /{ }^{152} \mathrm{Sm}=0.56081$ and Nd was corrected for mass fractionation using ${ }^{146} \mathrm{Nd} /{ }^{144} \mathrm{Nd}=0.7219$ and normalized using the Ames $\mathrm{Nd}$ standard $( \pm 0.0000202 \sigma$ average reproducibility). $\mathrm{Pb}$ was separated using the $\mathrm{Tl}$ doping method of White et al. (2000). After correcting for the mass bias using the Tl, samples were 
normalized to the triple-spike values for NBS-981 from Galer and Abouchami (1998). $\varepsilon_{\mathrm{Nd}}$ values were calculated using present day values of ${ }^{143} \mathrm{Nd} /{ }^{144} \mathrm{Nd}=0.512630$ and ${ }^{147} \mathrm{Sm} /{ }^{144} \mathrm{Nd}=$ 0.160 for CHUR (Bouvier et al., 2008).

\subsubsection{U-Pb Geochronology in zircon}

Traditional techniques for separating zircon concentrates were used, including crushing, fragmentation, pulverization, sieving. Water table and Frantz isodynamic were used for an initial density and magnetic separation respectively. Zircon concentrates were obtained after using methylene iodide $\left(3.30-3.33 \mathrm{~g} / \mathrm{cm}^{3}\right)$ to separate by density the non-magnetic fraction. Zircons were handpicked under the microscope and mounted in a 1-inch diameter epoxy puck and slightly ground and polished to expose the surface and keep as much material as possible for laser ablation analyses. Cathodoluminiscence (CL) images were obtained for zircons and then LA-ICP-MS U-Pb analyses were conducted using a New Wave Nd:YAG UV 213-nm laser coupled to a ThermoFinnigan Element 2 single collector, double-focusing, magnetic sector ICP-MS at Washington State University. Operating procedures, parameters and fractionation correction are described in Chang et al. (2006). Laser spot size was $30 \mu \mathrm{m}$ and repetition rate was $10 \mathrm{~Hz}$. He and Ar carrier gases delivered the sample aerosol to the plasma. Each analysis consists of a short blank analysis followed by 300 sweeps through masses 202, 204, 206, 207, 208, 232, 235, and 238, taking approximately 30 seconds. NIST 610 trace element glass was used to monitor $U$ and Th concentrations. Zircon standard Plesovice with an age of $337.13 \pm 0.37 \mathrm{Ma}$ (Sláma et al., 2008) was used. Uranium-lead ages were calculated using Isoplot 4.15 (Ludwig, 2003).

\subsubsection{Hf isotopes in zircon}

Hf isotope geochemistry analysis was performed on nine samples (Table 4.3) at the Geoanalytical Lab at Washington State University, using a ThermoFinnigan Neptune ${ }^{\mathrm{TM}} \mathrm{MC}$ ICP-MS equipped with 9 faraday collectors interfaced with a New Wave ${ }^{\mathrm{TM}} 213 \mathrm{~nm}$ UP NdYAG laser. Laser spot size was $40 \mu \mathrm{m}$ and the data were acquired in static mode with 60 second integrations. Details of analytical procedures and data treatment follow those of Vervoort et al. (2004) and DuFrane et al. (2007). For the Hf-depleted mantle model ages $\left(\mathrm{Hf}_{\mathrm{TDM}}\right)$, we used ${ }^{176} \mathrm{Hf} /{ }^{177} \mathrm{Hf}$ and ${ }^{176} \mathrm{Lu} /{ }^{177} \mathrm{Hf}$ for the individual zircon samples to determine their initial ${ }^{176} \mathrm{Hf} /{ }^{177} \mathrm{Hf}$ ratios at their crystallization ages. Projection back from zircon crystallization was calculated using a present value of 0.0150 for the estimated ${ }^{176} \mathrm{Lu} /{ }^{177} \mathrm{Hf}$ of 
continental crust (Vervoort and Patchett, 1996; Goodge and Vervoort, 2006). The depleted mantle Hf evolution curve was calculated from present-day depleted mantle values of ${ }^{176} \mathrm{Hf} /{ }^{177} \mathrm{Hf} \mathrm{DM}_{(0)}=0.283240$ and ${ }^{176} \mathrm{Lu} /{ }^{177} \mathrm{Hf} \mathrm{DM}_{(0)}=0.03979$ (Vervoort et al., 2015).

\subsection{RESULTS}

\subsubsection{Petrography, whole rock geochemistry and $\mathrm{Sr}-\mathrm{Nd}-\mathrm{Pb}$ isotopes of the Hatillo stock and el Bosque batholith}

The Hatillo stock intrudes pelitic schists of Mesozoic age that formed mottled schists with biotite accumulations close to the intrusion site, probably formed by contact metamorphism. It is mainly granodioritic in composition with plagioclase $\mathrm{An}_{25-35}$ (55-65\%), quartz (15-25\%), K-feldspar (5-15\%) and biotite (5-15\%). Hornblende is less than 2\% modal and accessory minerals include epidote, zircon, apatite and ilmenite. Tourmaline is present as a product of hydrothermal alteration. Myrmekites are observed when alkalifeldspar is in contact with plagioclase. Epidote forms locally euhedral prismatic crystals with apatite inclusions (Fig. 4.2). Biotite crystals can reach $1.5 \mathrm{~cm}$ length and some grains display poikilitic textures with chadacrysts of zoned plagioclase and hornblende. El Bosque batholith has a granodioritic composition with plagioclase An30-40 (50-60\%), quartz (20-30\%), Kfeldspar (10-20\%) and biotite (10-15\%); zircon and apatite are the main accessory minerals. Deformation twinning in plagioclase is common and along with quartz is recrystallized.

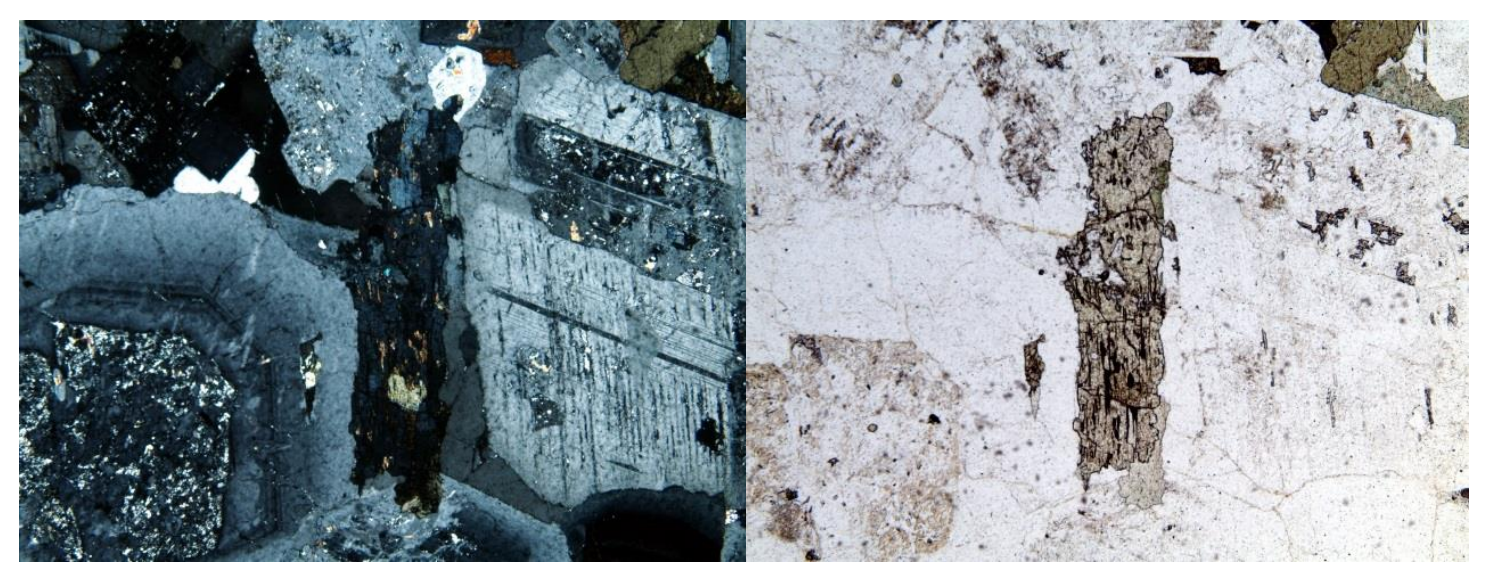

Figure 4.2. Prismatic epidote crystal in the Hatillo stock. Vertical length is $2.7 \mathrm{~mm}$ for each phtotograph.

In the $\mathrm{SiO}_{2}$ vs $\mathrm{K}_{2} \mathrm{O}$ diagram (Pecerillo and Taylor, 1976) the Hatillo stock and $\mathrm{El}$ Bosque batholith plot in the calc-alkaline field (Fig. 4.3A). Differences appear in the Alumina Saturation Index (ASI; Shand, 1943) where the Hatillo samples are metaluminous with a 
subtle trend to the peraluminous field, whereas the two samples of the El Bosque batholith are clearly peraluminous (Fig. 4.3B). Such a divergence occurs possibly due to the higher content of biotite in the El Bosque samples.

$\mathrm{Mg} \#\left(\mathrm{Mg} /\left[\mathrm{Mg}+\mathrm{Fe}^{2+}\right]\right)$ for the Hatillo stock range from 49.7 to 54.4 and $\mathrm{Sr} / \mathrm{Y}$ ratios from 34 to 55, El Bosque batholith has Mg\# of 43.2 in average and Sr/Y ratios from 28 to 34. Multi-element plots (Fig. 4.3C) normalized to the primitive mantle (Sun and McDonough, 1989), shows that both the Hatillo and El Bosque plutons have deep negative $\mathrm{Nb}$ and $\mathrm{Ti}$ anomalies, relative depletion of HFSE, and enrichments in $\mathrm{Ba}$ and $\mathrm{K}$ which are characteristic of a subduction related setting. A volcanic arc affinity is defined according to the $\mathrm{Hf}-\mathrm{Rb} / 30$ Ta*3 diagram (Harris et al., 1986; Fig. 4.3D). REE patterns (Fig. 4.3E) are characterized by the strong enrichment in light rare earth elements (LREE) and a strong depletion in heavy rare earth elements (HREE), with a high LREE/HREE ratio in both the Hatillo ( $\left.\mathrm{La} / \mathrm{Yb}_{\mathrm{N}}=8.4-19.6\right)$ and $\mathrm{El}$ Bosque $\left(\mathrm{La} / \mathrm{Yb}_{\mathrm{N}} \sim 27.3\right)$ plutons. These rocks are usually characterized by an absence of $\mathrm{Eu}$ anomalies, but in a few samples it can be barely detected $\left(\mathrm{Eu} / \mathrm{Eu}^{*}=0.8-1.0\right)$.

The Hatillo stock has an initial ${ }^{87} \mathrm{Sr} /{ }^{86} \mathrm{Sr}$ average value of 0.7047 , whereas sample $(\mathrm{CH} 21 \mathrm{~B})$ show a lower value of 0.7031 . Initial ${ }^{143} \mathrm{Nd} /{ }^{144} \mathrm{Nd}$ isotopes ranges from 0.512604 to $0.512648\left(\varepsilon_{\mathrm{Nd}(\mathrm{i})}\right.$ from +0.84 to +1.06$)$. ${ }^{206} \mathrm{~Pb} /{ }^{204} \mathrm{~Pb}$ ratios are from 18.814 to 18.978 , ${ }^{207} \mathrm{~Pb} /{ }^{204} \mathrm{~Pb}$ values range from 15.625 to 15.633 and $208 \mathrm{~Pb} / 204 \mathrm{~Pb}$ ranges from 38.762 to 38.815. The Bosque batholith has higher initial ${ }^{87} \mathrm{Sr} /{ }^{86} \mathrm{Sr}(0.7062)$ and lower initial ${ }^{143} \mathrm{Nd} /{ }^{144} \mathrm{Nd}\left(0.512455\right.$ with an $\varepsilon_{\mathrm{Nd}(\mathrm{i})}$ of -1.98$)$ than the Hatillo stock. ${ }^{206} \mathrm{~Pb} /{ }^{204} \mathrm{~Pb}$ ratios are of $18.764,{ }^{207} \mathrm{~Pb} /{ }^{204} \mathrm{~Pb}$ of 15.575 and ${ }^{208} \mathrm{~Pb} /{ }^{204} \mathrm{~Pb}$ of 38.655 . 


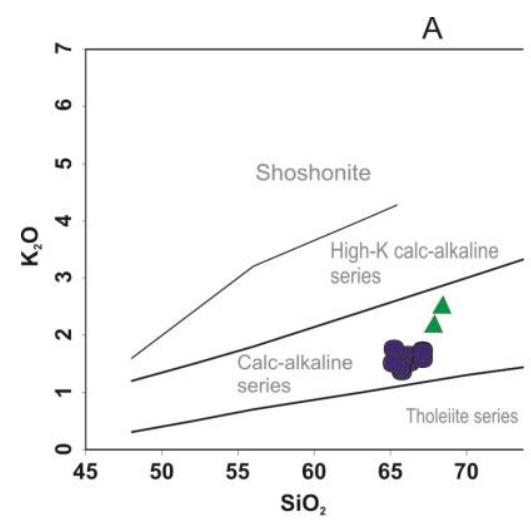

B
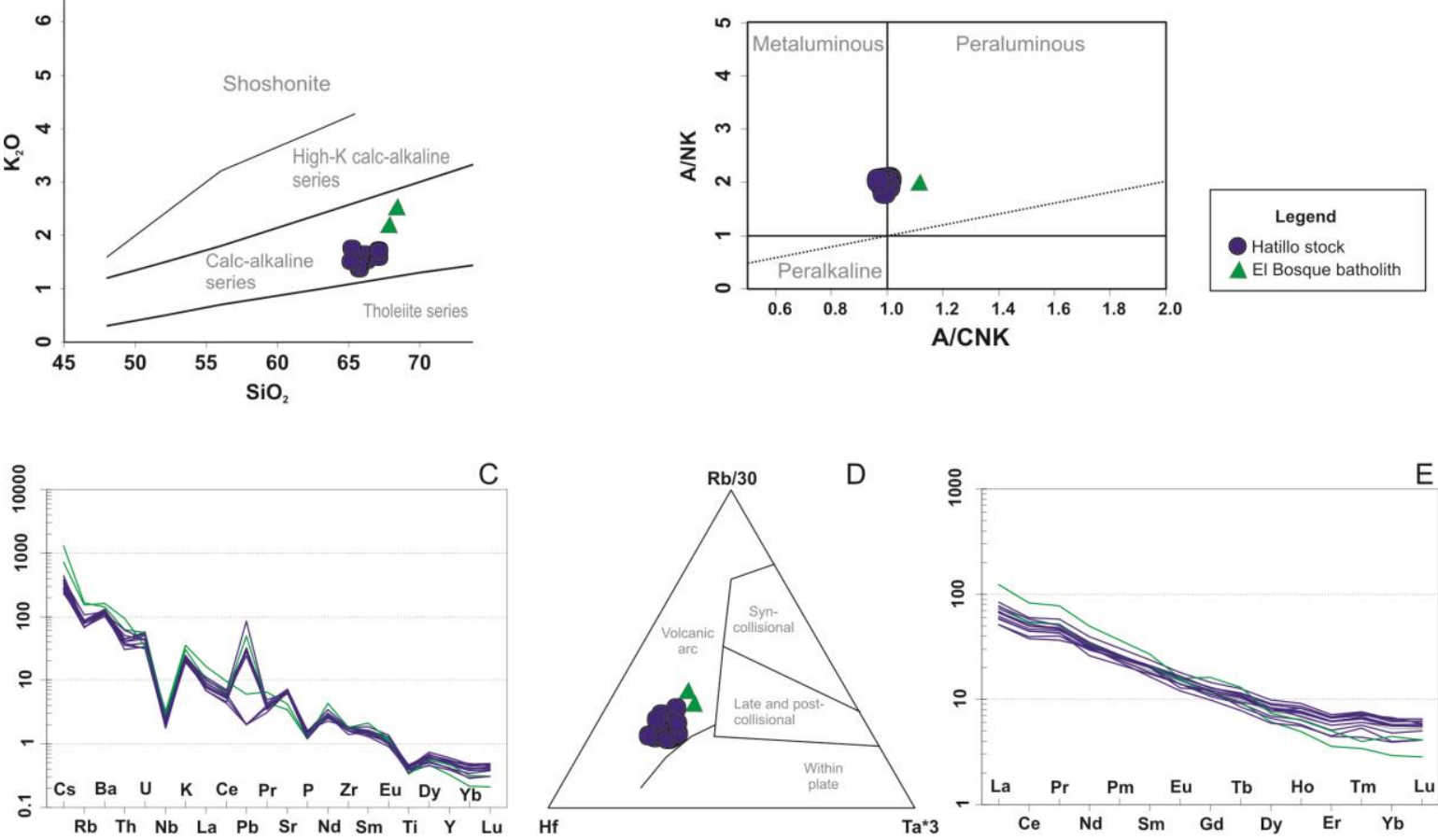

Figure 4.3. Geochemical classification and discrimination diagrams of samples from the studied plutons. A: Alkalinity index diagram of Pecerillo and Taylor (1976). B: Alumina saturation index diagram of Shand (1943). C: Multi-element plot normalized to primitive mantle according to Sun and McDonough (1989). D: Hf-Rb/30Ta*3 geotectonic discrimination diagram of Harris et al. (1986). E: Chondrite normalized REE patterns according to Nakamura (1974).

\subsubsection{Zircon $\mathrm{U}-\mathrm{Pb}$ ages and $\mathrm{Hf}$ isotopes}

Zircon CL images (Fig. 4.4), Concordia ages and Hf isotopes were obtained from a total of nine samples of the Hatillo (8) and El Bosque (1) plutons. 30 to 40 zircon rims were analyzed per sample, whereas Hf isotopes were obtained from eight dated zircons from each sample at the same spot where the ages were obtained. Ages from each pluton are presented in Figure 4.5.

Zircons in the CL images (Fig. 4.4) are euhedral with sizes varying between 120 and $400 \mu \mathrm{m}$. They normally are prismatic with a well-defined oscillatory zoning in agreement with their magmatic origin. Overgrowths were not observed. 


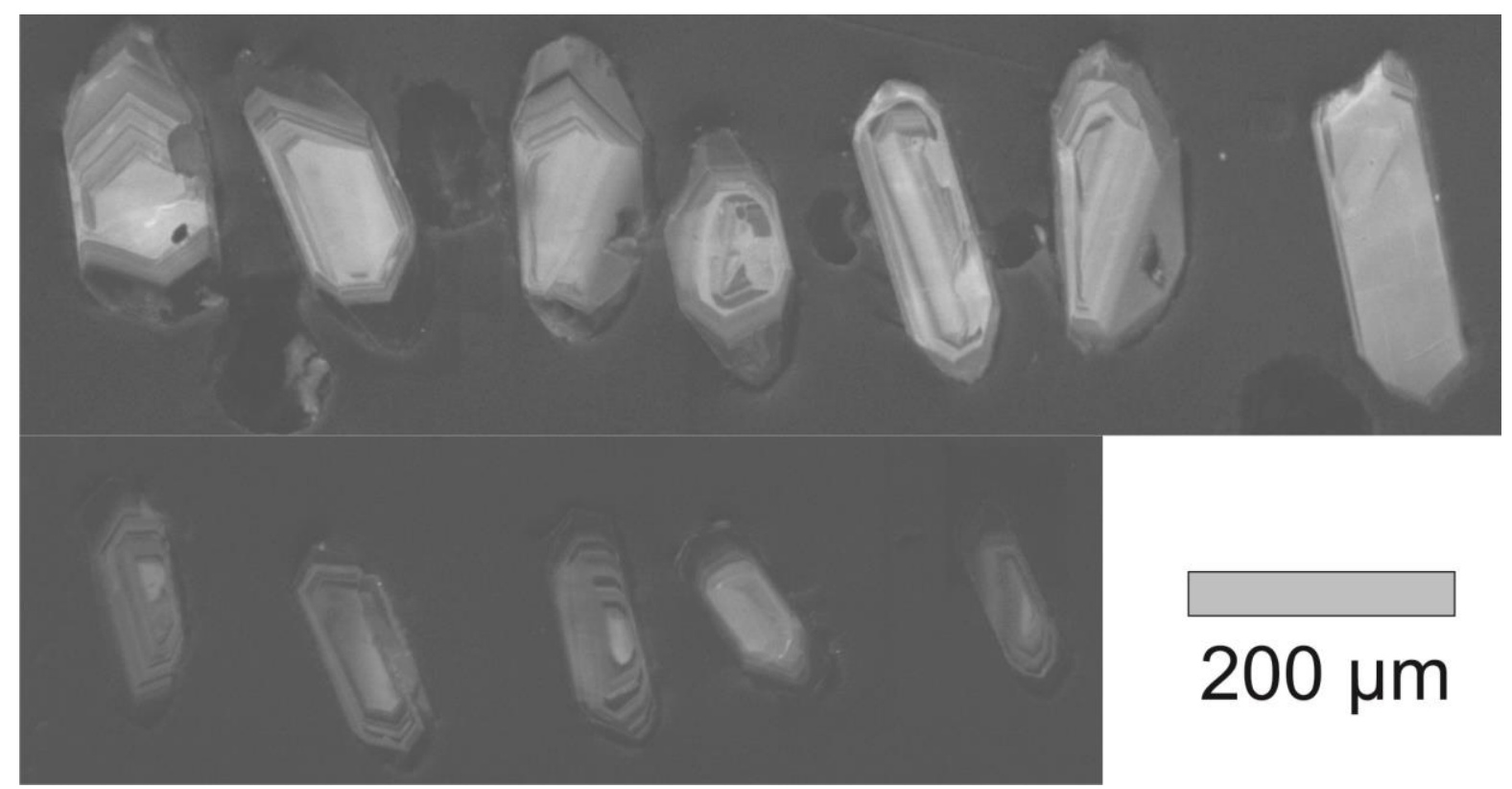

Figure 4.4. CL images from representative zircons from the Hatillo (upper) and El Bosque (lower) plutons.

The Hatillo stock show crystallization ages in the range of $55.0 \pm 0.7 \mathrm{Ma}$ and $53.2 \pm 1.3$ Ma (Fig. 4.5), which are similar to U-Pb ages reported by Bayona et al. (2012) obtained on the same stock. Initial $\varepsilon_{\mathrm{Hf}}$ isotope values in zircon ranges from -0.6 to +6.1 (Fig. 4.6). A core $\mathrm{U}-\mathrm{Pb}$ age of $1000 \mathrm{Ma}$ was found and with initial $\varepsilon_{\mathrm{Hf}}$ of +4.4 . 

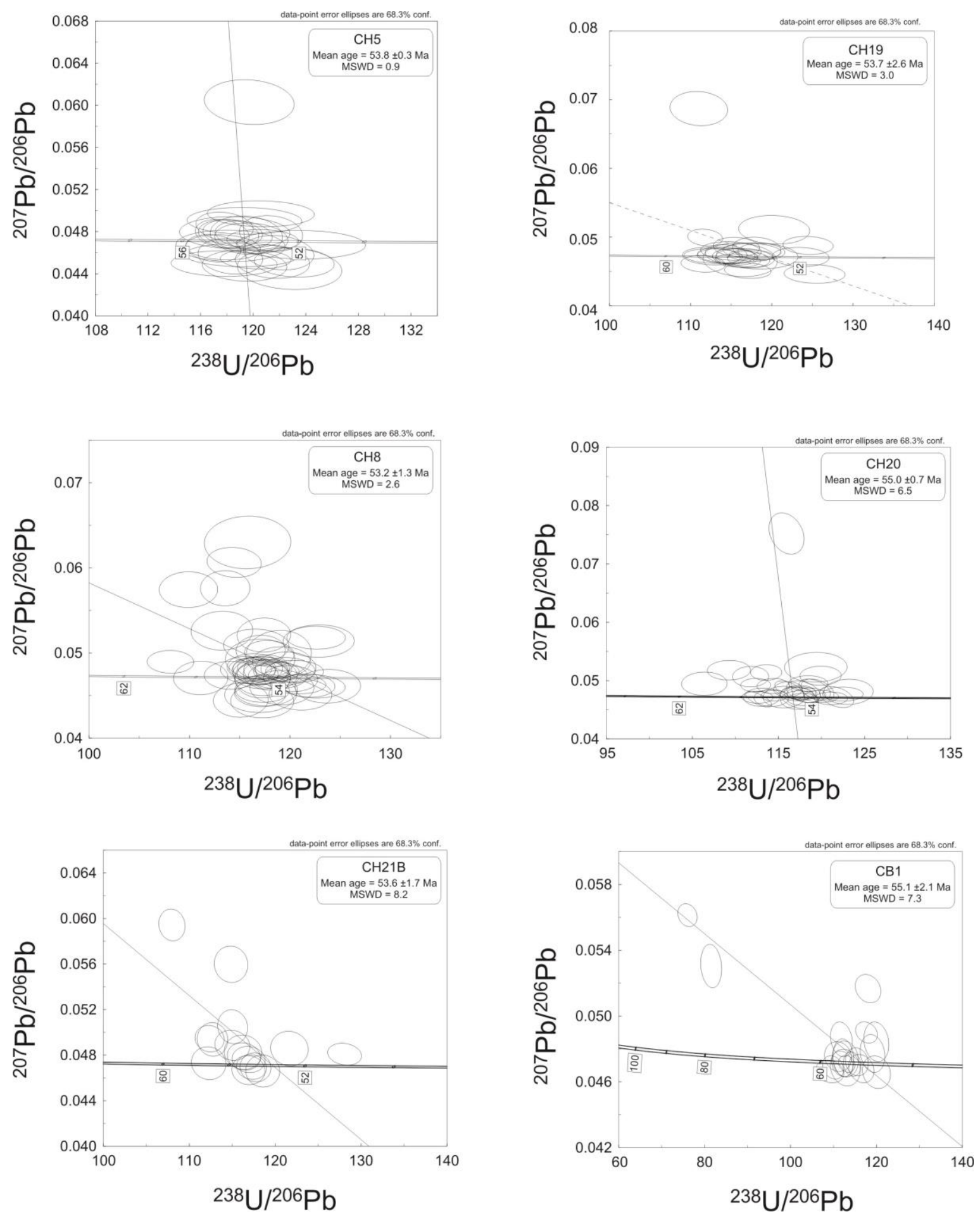

Figure 4.5. U-Pb Concordia ages obtained from plutons of the Central Cordillera: Hatillo stock and El Bosque batholith.

El Bosque batholith yielded a crystallization age of 55.1 $\pm 2.1 \mathrm{Ma}$ (Fig. 4.5). Two crystals provided older ages (c. $238 \mathrm{Ma}$ ) which we attribute to inheritance. Initial $\varepsilon_{\mathrm{Hf}}$ values ranging from -4.5 to +1.3 are more radiogenic when compared with the others granitoids (Fig. 4.6). 


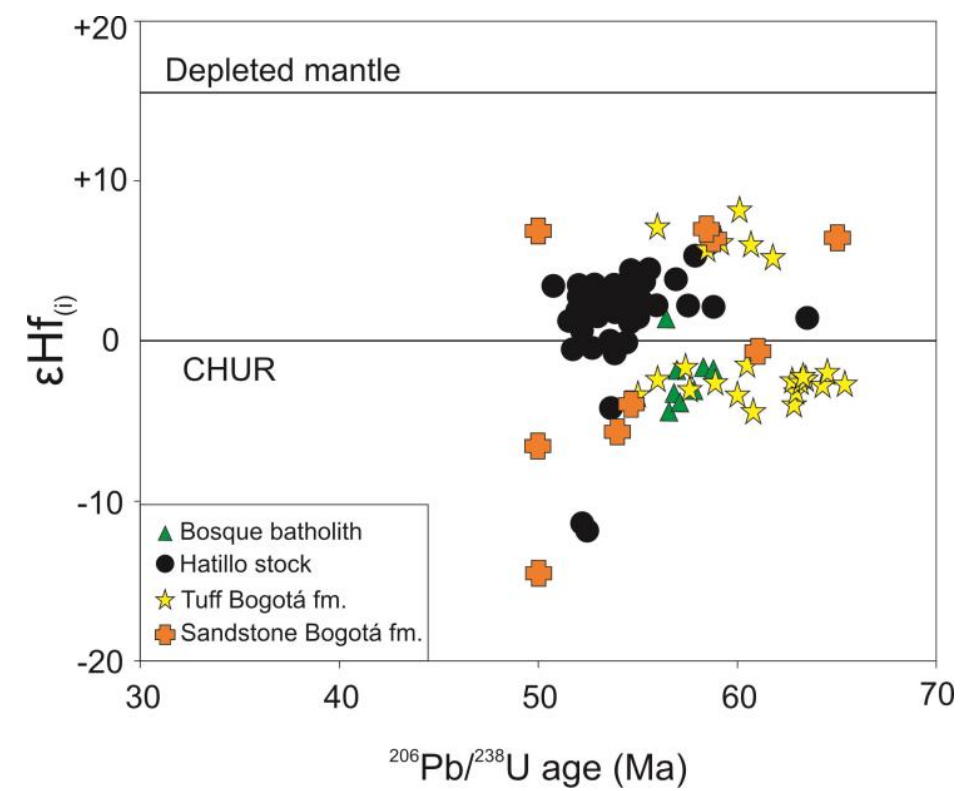

Figure 4.6. Initial $\varepsilon_{\mathrm{Hf}}$ vs ${ }^{206} \mathrm{~Pb} /{ }^{238} \mathrm{U}$ age. Data from Paleogene igneous and detrital zircons from Central and Eastern Cordilleras of Colombia.

\subsubsection{Volcanoclastic rocks}

Samples from the Eastern Cordillera are Late Paleocene to Early Eocene levels from the Bogotá Formation (Usme section) including a sandstone (litharenite) and a tuffaceous level with 50-65 Ma detrital zircons. In these same samples Bayona et al. (2012) first identified the Paleogene magmatic zircons, we decided to get insight into their possible sources and test with Hf isotopes their relation with Central Cordillera sources or the existence of unexposed magmatic centers. We have analyzed 105 detrital zircons from two samples of the Bogotá Formation, both samples have yield late Paleocene to early Eocene zircons (39 zircon crystals; 37\%), as well as Mesozoic to Precambrian zircons population in the litharenite (D937).

\subsubsection{Pre-Paleogene zircons}

The older detrital zircon grains are characterized by Mesoproterozoic to early Neoproterozoic (1701 - 778 Ma; 10 grains) and Paleozoic (525 - 264 Ma; 7 grains) ages. The Proterozoic zircons have a wide range of initial $\varepsilon_{\mathrm{Hf}}$ values ranging from -8.7 to +7.4 whereas Paleozoic zircons range from -11.3 to -1.0 (Fig. 4.7).

Triassic (244 - $210 \mathrm{Ma} ; 4$ grains) and Jurassic (195 - $146 \mathrm{Ma} ; 10$ grains) detrital zircons show initial $\varepsilon_{\mathrm{Hf}}$ values, respectively, from -3.5 to +8.8 and from -10.2 to +9.9 (Fig. 4.4). A population of thirty-one Cretaceous zircons $(144-65 \mathrm{Ma})$ has initial $\varepsilon_{\mathrm{Hf}}$ values between -7.7 and +7.8 (Fig. 4.7 ). 


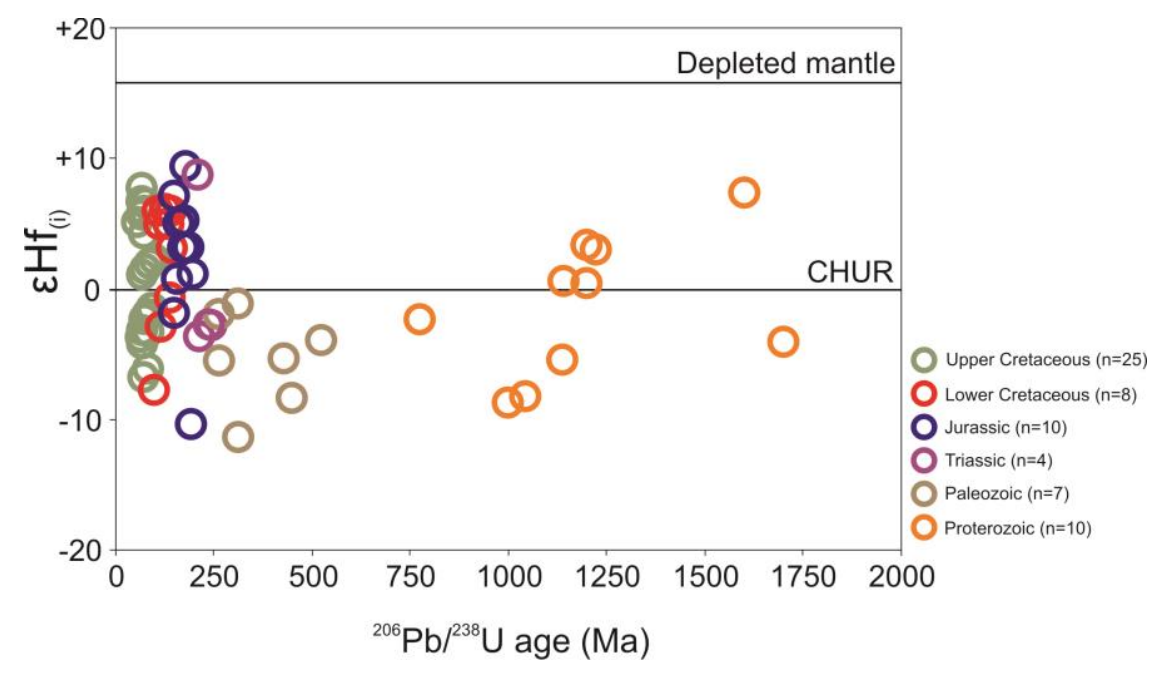

Figure 4.7. Hf isotope data from pre-Paleogene ( $>66 \mathrm{Ma}$ ) detrital zircons of the Bogotá Formation.

\subsubsection{Early Paleogene zircons}

Late Paleocene to Early Eocene detrital zircons with ages ranging from 65 to $50 \mathrm{Ma}$ has initial $\varepsilon H f$ values from -14.4 to +8.1 (Fig. 4.7). Eighteen zircons have positive values ranging from +4.5 to +8.1 and twenty-two are negative ranging from -14.4 to -0.6 , but predominantly between -7.2 to -0.6 (see it detailed in Fig. 4.6). When compared with zircons from Central Cordillera plutons, the more radiogenic cluster of this detrital record shows a close resemblance with El Bosque batholith (Fig. 4.6). Most of the Hf data of this pluton overlaps with those of the tuffaceous level of the Bogotá formation, whereas the Hatillo stock defines an isolated cluster, not related with any of the detrital data.

\subsection{DISCUSSION}

\subsubsection{Origin of the Paleogene plutonism}

The geochemical results of the Eocene magmatism, represented in our study by the Hatillo and El Bosque plutons, are characteristic of a convergent margin setting. They include $\mathrm{Nb}$ and $\mathrm{Ti}$ anomalies and relatively high LILE values recorded in $\mathrm{K} / \mathrm{Rb}$ ratios about 250 . $\mathrm{A}$ similar tectonic setting has been defined for other Eocene bodies such as the Parashi stock (Cardona et al., 2014) and the Santa Marta batholith (Cardona et al., 2011a) in the Colombian Caribbean region, as well as in the Manizales stock and the Antioquia and Sonson batholiths (Ordoñez et al., 2001; Leal-Mejía, 2011).

In the Colombian Andes, the 60 to $50 \mathrm{Ma}$ arc-related magmatism within the Central Cordillera (Bayona et al., 2012), followed a former extensional Late Cretaceous magmatism 
(Ibáñez-Mejía et al., 2007; Restrepo-Moreno et al., 2009; Ordóñez and Pimentel, 2002; Ordóñez-Carmona et al., 2008; Leal-Mejía, 2011; Villagómez et al., 2011), and a major arccontinent collisional event (Cardona et al., 2011b; Villagómez et al., 2011; Bayona et al., 2012; Spikings et al., 2015). In such geodynamic scenarios, the lower continental crust might have experienced crustal thickening associated to magmatic and tectonic underplating during continuous subduction and the oceanic-continent collision.

High $\mathrm{Sr} / \mathrm{Y}$ ratios (Fig. 4.8), $\mathrm{Al}_{2} \mathrm{O}_{3}$ and $\mathrm{Na}_{2} \mathrm{O}$ compositions were recognized in the $\mathrm{El}$ Bosque and Hatillo granitoids, as well as in the Paleocene to Eocene pulses of the Antioquian batholith in the Central Cordillera (Leal-Mejia, 2011), and in the Santa Marta and Parashi plutons in the Caribbean domain (Cardona et al., 2011b; 2014). Additionally, for the Eocene Manizales stock high Sr (580-685 ppm) and Rb (27-51 ppm) values have been reported (González and Londoño, 2002). This geochemical feature have been used to differentiate normal arc from adakite-like magmatic rocks, which are originated from the melting of a basaltic crust, and were initially considered as slab derived melts (Defant and Drummond, 1990). However, under normal subduction conditions the oceanic lithosphere in a subduction zone is subjected mostly to dehydration and do not extensively melt (Peacock et al., 1994; Poli and Schmidt, 2002). Therefore, alternative mechanism have been proposed to explain such a geochemical pattern commonly seen in different tectonic scenarios, and a caution on the use of adakite as a slab melting signature has been widely discussed (Richards and Kerrich, 2007; Moyen, 2009; Castillo, 2012).

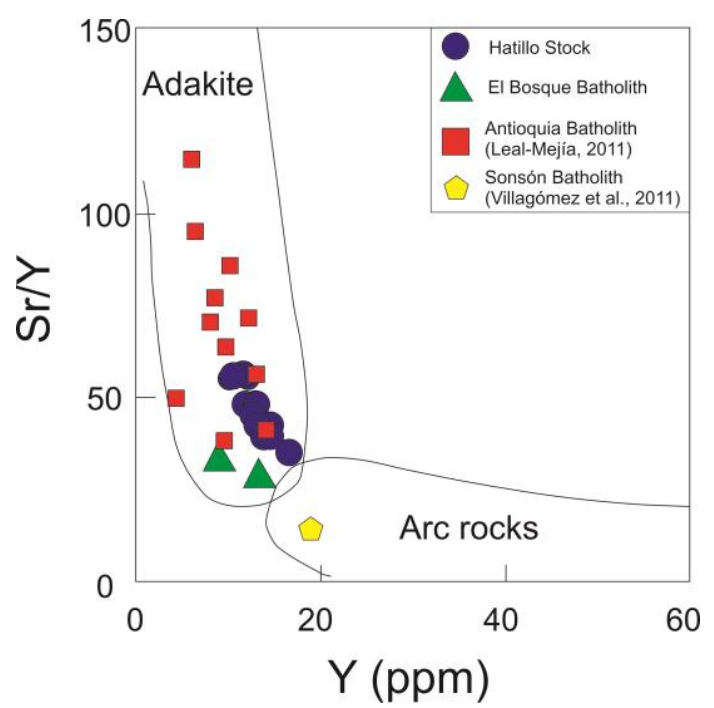

Figure 4.8. Sr/Y vs Y diagram after Defant and Drummond (1990) for adakite rocks discrimination. 
The alternative models for the presence of high $\mathrm{Sr} / \mathrm{Y}$ ratio in arc-related rocks include high pressure differentiation of arc magmas in the stability field of garnet (Macpherson et al., 2006), in which crustal thickness allows the stabilization of garnet and amphibole, that may or may not be related to delamination of the lower crust (Kay and Kay, 1993). Müntener et al. (2001) and Alonso-Perez et al. (2009) have pointed out that garnet stability is closely related with the $\mathrm{H}_{2} \mathrm{O}$ content in a silicate liquid and that at pressures between 0.8 to $1.2 \mathrm{GPa}(\sim 25-40$ $\mathrm{km}$ depth) in convergent settings, it becomes an essential fractionating phase that affects major and trace elements contents in calc-alkaline liquids. According to Lee et al. (2007), Y partitions into garnet and amphibole at high pressures (>12 kbar) and plagioclase is unstable, whereas is incompatible at low pressures. Kay and Mpodozis (2001) proposed that the $\mathrm{Sr} / \mathrm{Y}$ ratio is a suitable guide to discriminate the presence of garnet versus amphibole or pyroxene in the source of magmas and has been used as an indicator of pressure differentiation (Bachmann et al., 2005). Recently, Chiaradia (2015) identified a direct relationship between crustal depth and $\mathrm{Sr} / \mathrm{Y}$ ratios at intermediate to low $\mathrm{MgO}$ values (1-6 wt. \%) based on compiled data from arc rocks around the world. Such results indicated that $\mathrm{Sr} / \mathrm{Y}$ values higher than 20 can be related to thick crusts and consequently the magma differentiation at the arc roots would have occurred at elevated pressures. The variations in the $\mathrm{Sr} / \mathrm{Y}$ ratios has been used as major tracer of Meso-Cenozoic changes in crustal thickness on the North American Cordillera and the Central Andes (Chapman et al., 2015; Profeta et al., 2015).

Using the same approach is possible to document an increase in the $\mathrm{Sr} / \mathrm{Y}$ ratio since Late Cretaceous to Eocene (Fig. 4.9), when evaluating the Jurassic to Eocene magmatic record of the Colombian Andes. This suggest that the crustal thickness was certainly taking place in the Northern Andes, due both to arc growth and collisional tectonics (Cardona et al., 2011a; Villagómez et al., 2011; Bayona et al., 2012; Spikings et al., 2015). Leal-Mejia (2011) have suggested that the adakite-like signature identified in the Paleogene facies of the Antioquia batholith can be related with lithosphere delamination after the Late Cretaceous to Paleocene collision. Therefore, this model may be precluded by the discrete sized plutons of the Central Cordillera and a lack of associated basic magmatism as seen in Cenozoic delamination zones such as the Central Andes (Coldwell et al., 2011) and Western United States (Ducea, 2001). It is therefore proposed that the adakite-like signatures of the Hatillo and El Bosque plutons (this work), the Manizales stock (González and Londoño, 2002) and the Antioquia batholith are akin to magmatic differentiation at a pressure of $1-1.2 \mathrm{GPa}$ that allow garnet stabilization (Müntener et al., 2001; Alonso-Perez et al., 2009; Chiaradia, 2009; 
Rooney et al., 2011). Altough the $\mathrm{Sr} / \mathrm{Y}$ and $\mathrm{La} / \mathrm{Yb}$ ratios of the Caribbean plutons such as Santa Marta and Parashi (Cardona et al., 2011b; 2014) are lower than those of the Central Cordillera, they suggest that melting took place in the amphibole stability (Cardona et al., 2014), indicating some significant crustal thickness. A similar petrogenetical model in which an inherited thick lower crust influences arc magmatism has been documented by Schwartz et al. (2011) in the Late Jurassic of the NW United States. The presence of magmatic epidote in the Hatillo stock and also reported in the Paleocene Manizales stock (Plazas et al., 2013), is also compatible with high pressure crystallization conditions of these magmas (Schmidt and Poli, 2004; Matsumoto et al., 2014; Evans and Vance, 1987).

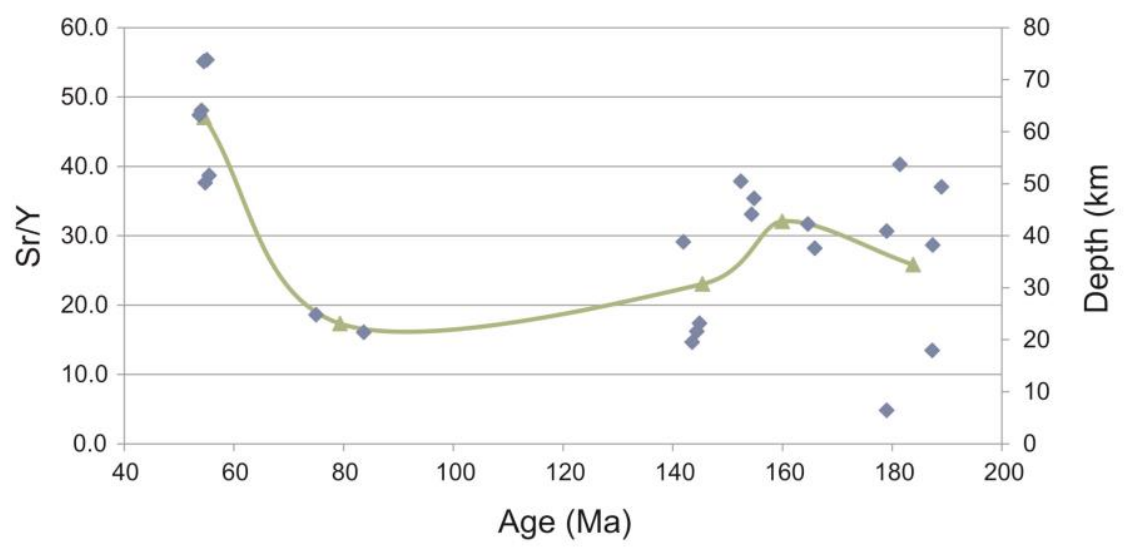

Figure 4.9. Variation of crustal depth with age in the western margin of the Colombian Andes during the MesoCenozoic. Blue points represent the whole data used to show the variations after applying the filters suggested by Profeta et al. (2015). Green line is an average every $\sim 10$ Ma. Relations between Sr/Y ratio and depth are according to Profeta et al. (2015).

The lower Mg\# $(43.2-54.4)$ and isotopic compositions with initial $\varepsilon_{\mathrm{Hf}}$ from -11.8 to $+6.9,{ }^{87} \mathrm{Sr} /{ }^{86} \mathrm{Sr}$ from 0.7031 to 0.7062 and ${ }^{143} \mathrm{Nd} /{ }^{144} \mathrm{Nd}$ from 0.512455 to $0.512648\left(\varepsilon_{\mathrm{Nd}}(\mathrm{i})=-\right.$ 1.98 - +1.76) (Fig. 4.10A), suggest mixing of continental and juvenile basaltic sources (Chiaradia, 2015; Tarney and Jones, 1994). Thus, a slab-melting scenario that is characterized by remarkable non-radiogenic and high $\mathrm{Mg \#}$ associated to the mix between the slab melts and the overlying mantle (Defant and Drummond, 1990; Moyen, 2009) is discarded. Whole rock lead isotopes also account for heterogeneous, mixed sources as they plot along the orogene curve (Fig. 4.10B) in the ${ }^{208} \mathrm{~Pb} /{ }^{204} \mathrm{~Pb}$ vs ${ }^{206} \mathrm{~Pb} /{ }^{204} \mathrm{~Pb}$ diagram of Zartman and Doe (1981), and are also characterized by moderate to radiogenic values of ${ }^{207} \mathrm{~Pb} /{ }^{204} \mathrm{~Pb}$ in the Hatillo and Bosque stock (15.625 to 15.575and 15.633). 
After evaluating the feasibility of the high-pressure differentiation as the most appropriate mechanism to reach the high $\mathrm{Sr} / \mathrm{Y}$ signature, a remaining question is the origin of the melts. A plausible source for this would be the melting of diapirs composed of sediment, altered oceanic crust and peridotites transferred from the subduction zone towards the lithosphere, which are then emplaced at the lower crust (Castro, 2014). This model of has been supported by experimental work (Gerya and Yuen, 2003; Vogt et al., 2013; Castro, 2014) and discussed as an alternative origin for the tonalite-granodiorite magmas in arc settings (Castro et al., 2010; Castro, 2014). Melting temperatures for this process are higher than $1,000{ }^{\circ} \mathrm{C}$, which favors water-undersaturated magma generation and hence the late formation of amphibole (Castro et al., 2010; Castro, 2014). This is a feature present in our samples and reported in other Eocene plutons of the Central Cordillera (González and Londoño, 2002; Plazas et al., 2013; Leal-Mejía, 2011) where this mineral is less than $5 \%$ modal.
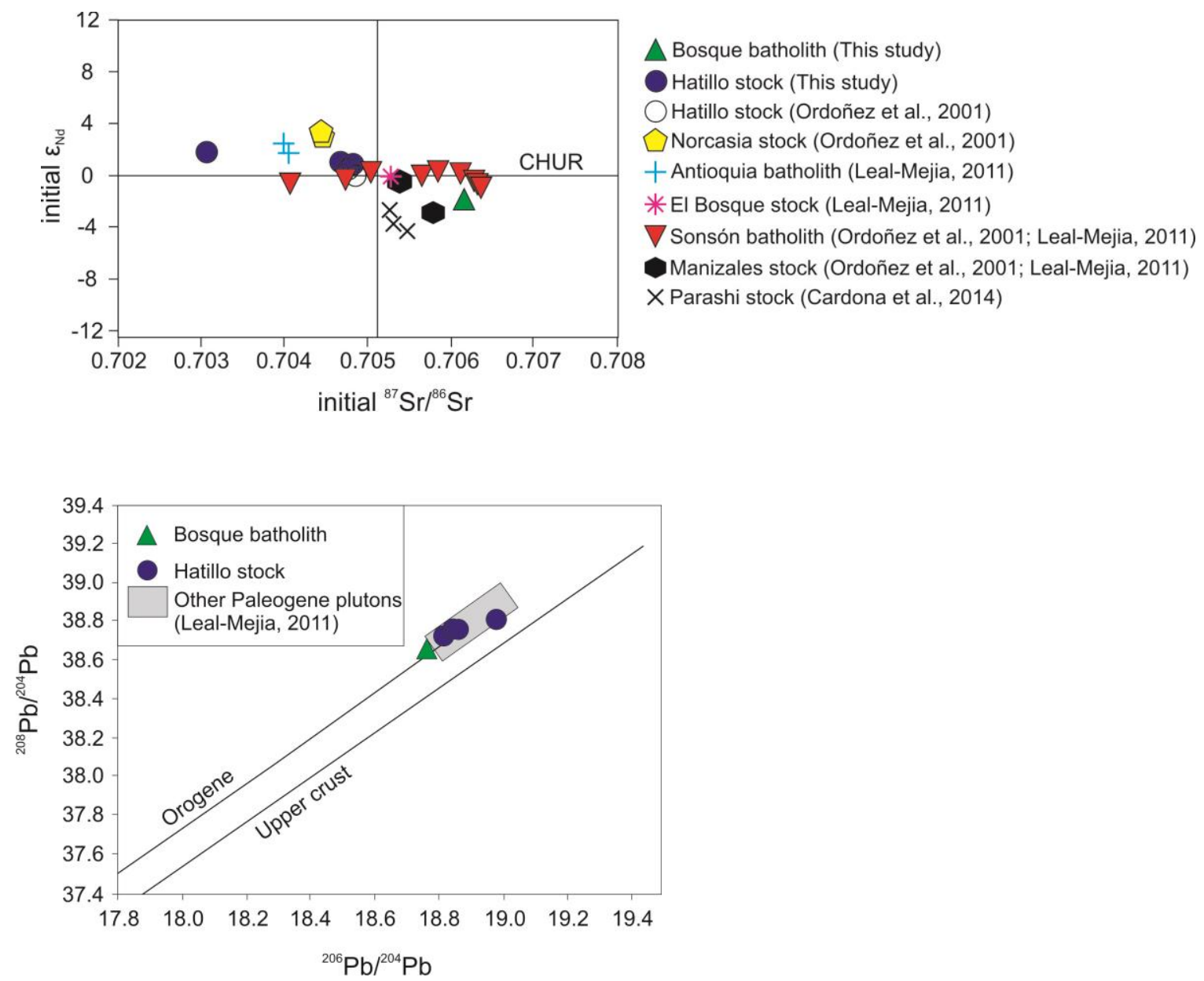

Figure 4.10. A. $\varepsilon_{\mathrm{Nd}(\mathrm{i})} \mathrm{vs}^{87} \mathrm{Sr} /{ }^{86} \mathrm{Sr}$. B. Lead isotopic evolution curve according to the plumbotectonics model of Zartman and Doe (1981). Both diagrams show a comparing between the Eocene plutons analyzed with other Paleogene plutons from the Central Cordillera and the Colombian Caribbean. 
Due to the deep origin of these melts, the stock dimensions that characterize the plutonic rocks of the Paleogene arc, might be the result of the difficulty of magmas to be emplaced at the upper crust due to its thickness. Although an exception seems to be the Paleogene Sonsón batholith with Sr/Y ratio of 14 (Fig. 4.8) (60 to 55 Ma: Ordóñez et al., 2001; Leal-Mejía, 2011; Villagómez et al., 2011). It may suggest that garnet was not a phase present during the differentiation that gave rise to this pluton. However, a more systematic study of this batholith is needed to fully understand its origin.

\subsubsection{Detrital zircon signatures}

Provenance and sedimentological analysis in Eastern Colombian basins have suggested the existence of Paleogene detritus of volcanic origin and tuffaceous material more than $400 \mathrm{~km}$ from the Paleogene arc in the Central Cordillera (Fig. 4.9). The Hf isotope signatures of the Early Paleogene zircons measured in detrital samples of the Eastern Cordillera suggest that some of these zircons may be sourced from the Central Cordillera arcs. Although this Cordilleran source is a simple connection, sedimentological characteristic from some of these volcanic horizons, including their apparent proximal character, do not rule out the existence of some volcanic focus in eastern Colombia that have been covered or eroded (Bayona et al., 2012; 2015). If this is the case, such volcanism temporally overlie with a major phase of local basin inversion in a compressive setting (Bayona et al., 2012; 2013), and therefore the volcanism may be explained by some kind of distal process, probably associated to mantle flow that allow melting of the crust or the mantle.

Shear-driven cavity flow of the asthenosphere on inherited extensional structures (Conrad et al., 2010; 2011), such as those documented on Eastern Colombia (Sarmiento-Rojas et al., 2006; Mora et al. 2009) is commonly considered as a process that may trigger melting. Thus, mantle flow and inland melting associated with basin inversion and exhumation recorded east of the Central Cordillera, may be prompted by the transition of the normal subduction setting to a flat slab configuration. This seems to affect the Colombian margin because of the subduction of a thick Caribbean plate under South America (Cardona et al., 2011a; Bayona et al., 2012). Moreover, the apparent magmatic hiatus in the Late Eocene may be also related to such a scenario, although oblique convergence during the Paleogene has also influenced magmatic fluxes in the margin (Bayona et al., 2012). 


\subsection{CONCLUSIONS}

$\mathrm{U}-\mathrm{Pb}$ ages and $\mathrm{Hf}$ isotopes in zircons together with petrography and whole rock geochemistry in plutonic rocks from the Central Cordillera, allow us to understand the mechanisms that lead to the magmatism in Colombia between 60 and $50 \mathrm{Ma}$. The processes involved in the origin of such magmatism account for a high-pressure differentiation of the Central Cordillera granitoids that give rise to adakite-like signature in the plutonic rocks. This compositional feature is related to magmatic differentiation of the melts in a thick lower crust, that experienced both tectonic and magmatic underplating during the former Cretaceous to Early Paleocene arc and collisional events that experienced the NW margin of South America. Melt source include the tectonic mélange composed by sediments and basalts transported by subduction. Emplacement of the plutonic rocks to the upper crust might be difficult by the already thickened crust, resulting in small sized plutons. Hf isotopic signatures of Paleogene detrital zircons from Eastern Colombia suggest a Central Cordillera source of zircons. However, a proximal eastern volcanic focus is not discarded, since it may be associated to basin inversion and mantle flow formed during slab flattening. 


\title{
Capítulo 5
}

\section{Magnetic fabric (AMS, AAR) of the Santa Marta batholith (northern Colombia) and the shear deformation along the Caribbean plate margin ${ }^{4}$}

\begin{abstract}
Anisotropy of low-field magnetic susceptibility (AMS) and anhysteretic remanence (AAR) were measured in the Santa Marta Batholith formed by subduction of the Caribbean Plate beneath the northern South America. The batholith, elongated in the N-S direction, records multiple pulses of quartzdiorite to tonalite and granodiorite magmas between 58 and $49 \mathrm{Ma}$. The high mean magnetic susceptibility $\left(4 \times 10^{-3} \mathrm{SI}\right)$ combined with thermomagnetic and partial magnetic remanence measurements indicate that the magnetic susceptibility depends on Ti-poor magnetite. AMS is defined by ellipsoids that are dominantly oblate. The foliation was used to distinguish a narrow band of E-trending magnetic structures that separate the batholith in two lobes. The southern lobe is characterized by foliations that are broadly parallel to the contact with the wall rocks, while the northern lobe by foliations oblique to the batholith elongation. Late tonalitic magmas dated at c. $50 \mathrm{Ma}$ record, in turn, a fabric apparently controlled by E-trending tectonic events. Partial AAR indicates that the subfabrics of magnetite with different grain sizes are nearly parallel to AMS, therefore discarding the possibility of superposed fabrics with different orientations. The magnetic fabric pattern is consistent with a magma emplaced in an arc setting deformed by a dextral shear. Synthetic extensional shear bands localize the magmatic deformation along Easttrending corridors that probably were exploited to emplace the late magmatic pulses. Accretion of the Eocene batholith and the Late Cretaceous metasedimentary host-rocks to the South American continent defines a major strike-slip shear suture that resulted from the oblique convergence of the Caribbean Plate.
\end{abstract}

\footnotetext{
${ }^{4}$ Salazar, C.A., Bustamante, C., Archanjo, C.J., 2016. Magnetic fabric (AMS, AAR) of the Santa Marta batholith (northern Colombia) and the shear deformation along the Caribbean plate margin. Journal of South American Earth Sciences.
} 


\subsection{INTRODUCTION}

Anisotropy of magnetic susceptibility (AMS) in granitic rocks is a reliable recorder of the kinematics of regions in which plutons are emplaced (Archanjo et al., 1994; Neves et al., 1996; Wilson and Grocott, 1999; Moyen et al., 2003; Stevenson et al., 2007; Wei et al., 2014, among many others), being used for plate tectonic analysis of orogenic belts (Benn et al. 2001). AMS studies of granite plutons from magmatic arc settings, such as in Chilean Central Andes or in western North America Cordillera, have shown that magnetic fabrics are either strongly coupled with the arc deformation (Tikoff and Saint-Blanquat, 1997; Wilson, 1998; Fawcett et al., 2003; Titus et al., 2005) or record structures formed by body (ascent, convection) forces and tectonic-related fabrics (Saint-Blanquat et al., 2001; Parada et al., 2005). Magnetic fabrics orientations controlled by the deformation in magmatic arcs have been documented in Jurassic to Middle Cretaceous plutons emplaced in the Central Andean Belt (Wilson, 1998) when the arc was submitted to extension (Ramos, 2009). According to Grocott and Taylor (2002), the granitic complexes were accommodated in the crust by a mechanism of floor-depression and/or roof uplift that allowed a vertical transfer of magma without important horizontal displacement of the wall rocks. In contrast AMS of the MidCretaceous Las Tazas batholith evidence finite strains when the arc was deforming by transtension (Wilson and Groccot, 1999). AMS, therefore, was interpreted as recording a tectonic overprint in the final stages of the magmatic crystallization due to the lateral movement of the Atacama Fault (Grocott and Taylor, 2002).

Between Late Cretaceous and Eocene the Central and Northern Andes were submitted to contraction (Ramos, 2009). While in the Central Andes the contraction would be linked to the shallowing of the subduction zone, convergence between the oceanic Caribbean Plate and the Northern South America Plate would account for the accretion of terranes and magmatic activity along the margin of Ecuador and Colombia (Pindell and Kennan, 2009; Cardona et al., 2011a; Boschman, et al. 2014). Likewise, the northward migration of the triple junction between the Farallon and Caribbean plates relative to the South American Plate would indicate that the collage of terranes was accompanied by large dextral shearing (Kennan and Pindell, 2009). The Caribbean Plate is, in present day, bordered by the magmatic arcs of the Panama and Antilles (Fig. 5.1). A considerable proportion of the plate consists of a thick (up to $20 \mathrm{~km}$ ) oceanic crust referred to as Caribbean-Colombian Oceanic Plateau (Kerr, 2014). The plateau would have been formed over the Galapagos hot-spot and gradually moved to its present position over the past $90 \mathrm{Ma}$ (Duncan and Hargraves, 1984; Kerr and Tarney, 2005; 
Pindell and Kennan, 2009). Subduction of the Caribbean Plate between 60-40 Ma resulted in the emplacement of calc-alkaline tonalites, granodiorites and quartz diorites in the Central Cordillera, Sierra Nevada de Santa Marta and Guajira Peninsula in Colombia (Fig. 5.2) (Bayona et al., 2012; Cardona et al. 2014). The relatively short period ( $<15 \mathrm{Ma}$ ), wide areal distribution of the igneous bodies and the abrupt interruption of the magmatism in Middle Eocene are attributed to the difficulty of the thick oceanic crust to subduct (Bayona et al., 2012).

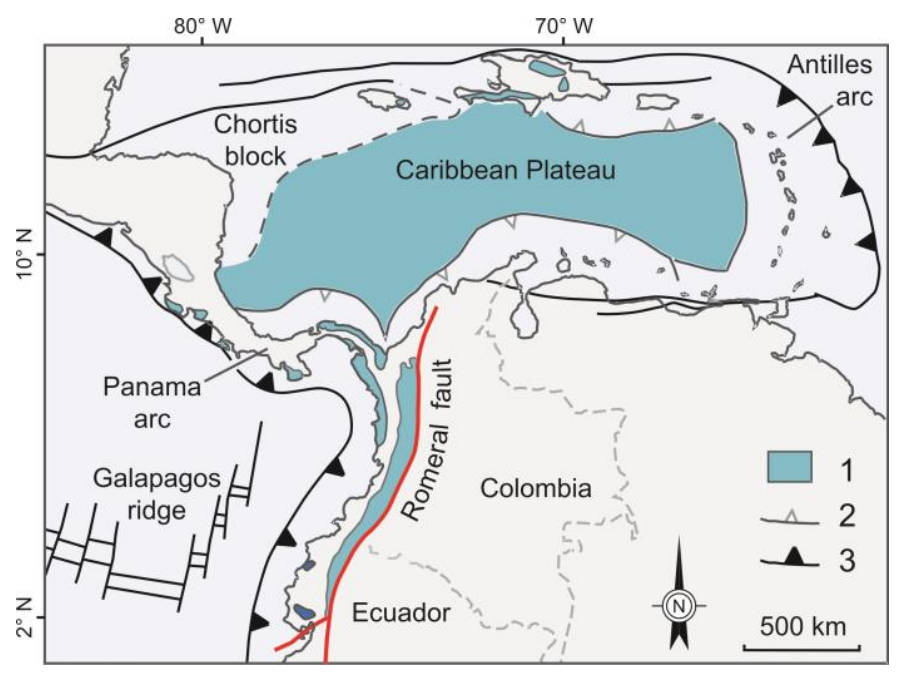

Figure 5.1. Caribbean oceanic plateau bounded by the subduction zones of Antilles and Panamá, and strike-slip (transform) faults. Accreted oceanic terranes related to the oblique subduction of the Caribbean plate beneath South America are shown to the Ecuador, Colombia and Panama to the west of the Romeral fault system. 1. Cretaceous oceanic rocks; 2, thrust; 3, subduction zone (modified from Kerr, 2014).

Our study is focused on the Santa Marta batholith, one of the largest Eocene pluton of Colombia that intruded subduction complexes of the leading-edge of the Caribbean plate accreted to the northern margin of the South America (Cardona et al 2011a; Escalona and Mann, 2011). We use anisotropy of magnetic susceptibility to define the batholith magmatic fabric and anisotropy of anhysteretic remanence to investigate the possible contribution of superposed fabrics (Trindade et al., 1999; Usui et al., 2006) in an actively deforming arc setting. This study also documents the tectonic record in the pluton emplacement fabrics when the subducted plate contains thick oceanic crust.

\subsection{GEOLOGICAL SETTING}

The Andean Belt in Colombia can be divided in three major "cordilleras". The Western Cordillera (WC, Fig. 5.2) consists of slivers of oceanic plateau basalt, island arcs and volcano-sedimentary rocks accreted to South America at c. 75 Ma (Kerr and Tarney, 2005; Vallejo et al., 2006). The central Cordillera (CC) comprises mostly Late Paleozoic to Triassic 
foliated granitoid, amphibolite and migmatite interpreted to record crustal melts formed during extension and break-up of the western Pangea (Vinasco et al., 2006; Martens et al., 2014). These rocks were intruded by I-type Jurassic batholiths evolved in a continental arc setting due to east dipping subduction of the Farallon Plate (Aspden et al., 1987; Cochrane et al., 2014b). Paleozoic rocks including dispersed inliers of Grenvillian-aged basement characterize the Eastern Cordillera (EC), the Sierra Nevada de Santa Marta (SNSM) block and part of the Guajira Peninsula (Fig. 5.2; Cordani et al., 2005; Cardona et al., 2010). A suture zone would juxtapose the Eastern and the Central Cordilleras to characterize, respectively the Chibcha and Tahami Terranes (Restrepo and Toussaint, 1988), while the Sierra Nevada de Santa Marta would be a rotated block detached from the Central Cordillera in the Eocene (Montes, et al., 2010). In turn, slices of ultramafic-mafic rocks metamorphosed at medium- to high pressure and emplaced along the Cauca-Almaguer-San Jerónimo faults (hereafter named Romeral fault system; Fig. 5.1) define the suture zone between the Central and Western Cordilleras. Although covered by Cenozoic to recent sediments, the Romeral fault system has been traced to northern Colombia following the contact between Late Cretaceous and Paleozoic sequences (Fig. 5.2; Kennan and Pindell, 2009; Ramos, 2009).

The SNSM block consists of Paleozoic rocks intruded by Jurassic granitoids including remnants of high-grade metamorphic rocks of Grenvillian age. The Paleozoic metamorphic sequence (Sevilla belt of Tschanz et al., 1974) is juxtaposed to a narrow belt of Late Cretaceous pelitic to psamitic schists and amphibolites intruded by the Santa Marta batholith (Fig. 5.3). The host rocks of the batholith have been associated to forearc deposits related to the east-dipping subduction of the Caribbean plate and that were accreted to the South America margin by arc-continent collision (Cardona et al., 2011a). 


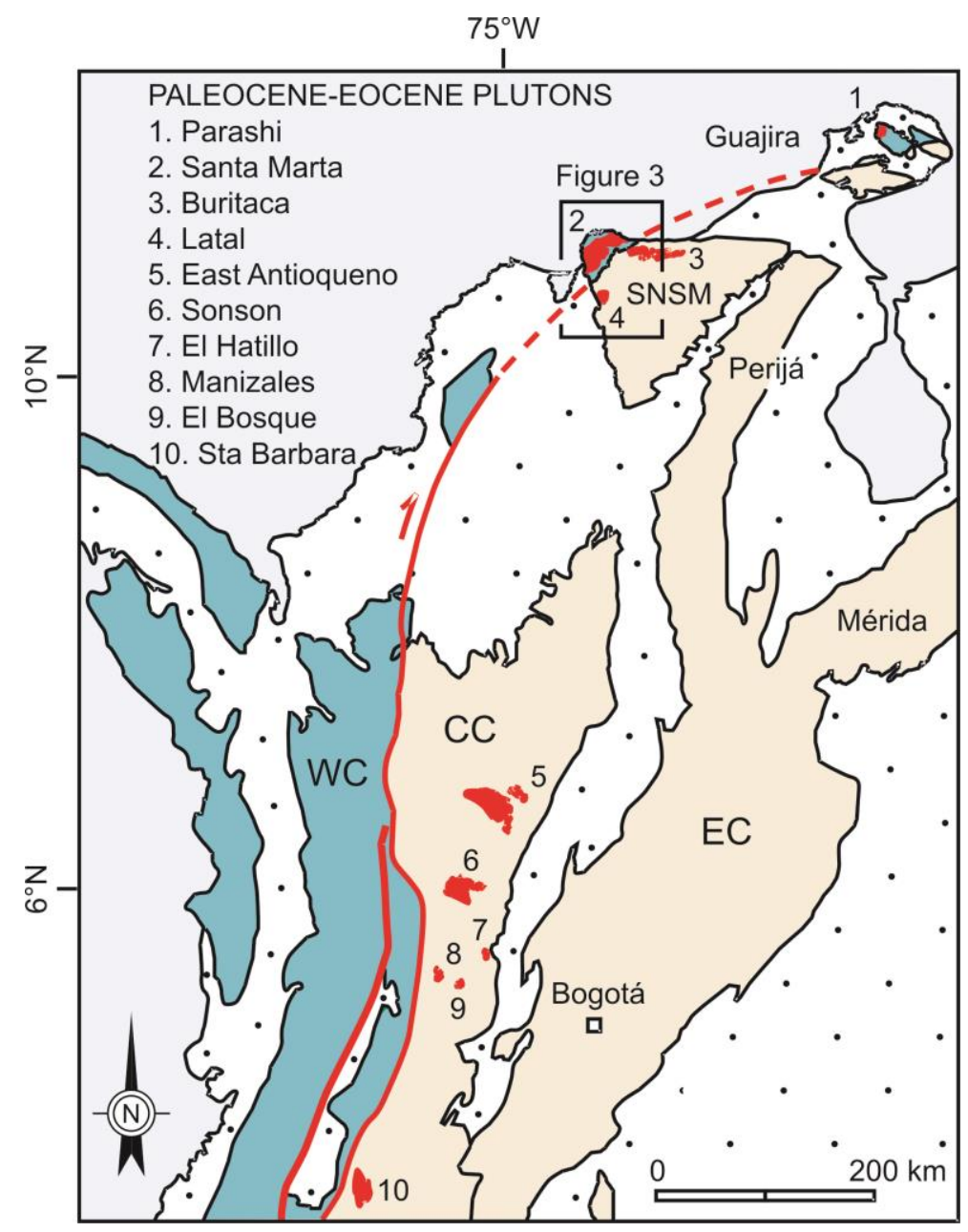

Figure 5.2. Simplified physiographic map of the northern Andes showing the Cretaceous oceanic rocks of the West Cordillera (WC) in contact with the Central Cordillera along the Romeral fault system. The Eastern Cordillera (EC) is separated from the Sierra Nevada de Santa Marta (SNSM) block and Central Cordillera by sedimentary deposits of the César-Rancheria and Magdalena basins. Plutonic rocks corresponding to the Paleocene-Eocene magmatic arc are shown in red (modified from Bayona et al., 2012).

\subsubsection{Early Paleogene magmatism in the Sierra Nevada de Santa Marta}

Two distinct magmatic events are recognized in the eastern part of the SNSM block. The older 65-63 Ma magmatism consists of leucogranite stocks with garnet, muscovite and biotite intruding Late Cretaceous metapelites and Paleozoic metamorphic rocks (Fig. 5.3). According to Cardona et al. (2011a), the Paleocene magmatism records the collision of Caribbean arc with the northern South American Plate. Tonalite, quartz diorite and granodiorite with crystallization ages between 58-50 Ma constitute the younger magmatic event (Bayona et al., 2012; Cardona et al. 2014), with the Santa Marta batholith representing the largest Eocene pluton (c. $600 \mathrm{~km}^{2}$ ) of the SNSM block. The batholith consists mostly of a tonalite with hornblende and biotite. Titanite, magnetite, ilmenite, apatite and zircon occur as accessory minerals. The microstructure is holocrystalline equigranular, medium- to coarse- 
grained, locally porphyritic and pegmatoid. Medium to fine-grained mafic enclaves with amphibole and biotite are relatively abundant. Tschanz et al. (1969) recognized a foliated to gneissic granitoid including a mafic gneiss xenolith situated along the eastern margin of the batholith (Fig. 5.4). Zircon U/Pb ages (LA-ICP-MS) yielded crystallization ages of tonalites and granodiorites between 58 and $55 \mathrm{Ma}$ (see location of samples in Fig. 5.4). A mafic enclave from the northwestern margin provided a zircon $\mathrm{U} / \mathrm{Pb}$ age of $57 \mathrm{Ma}$ and late porphyritic to equigranular dikes that cut the batholith and its wall-rocks yielded ages in the range of 56 and $52 \mathrm{Ma}$ (Duque 2009; Cardona et al. 2011a).

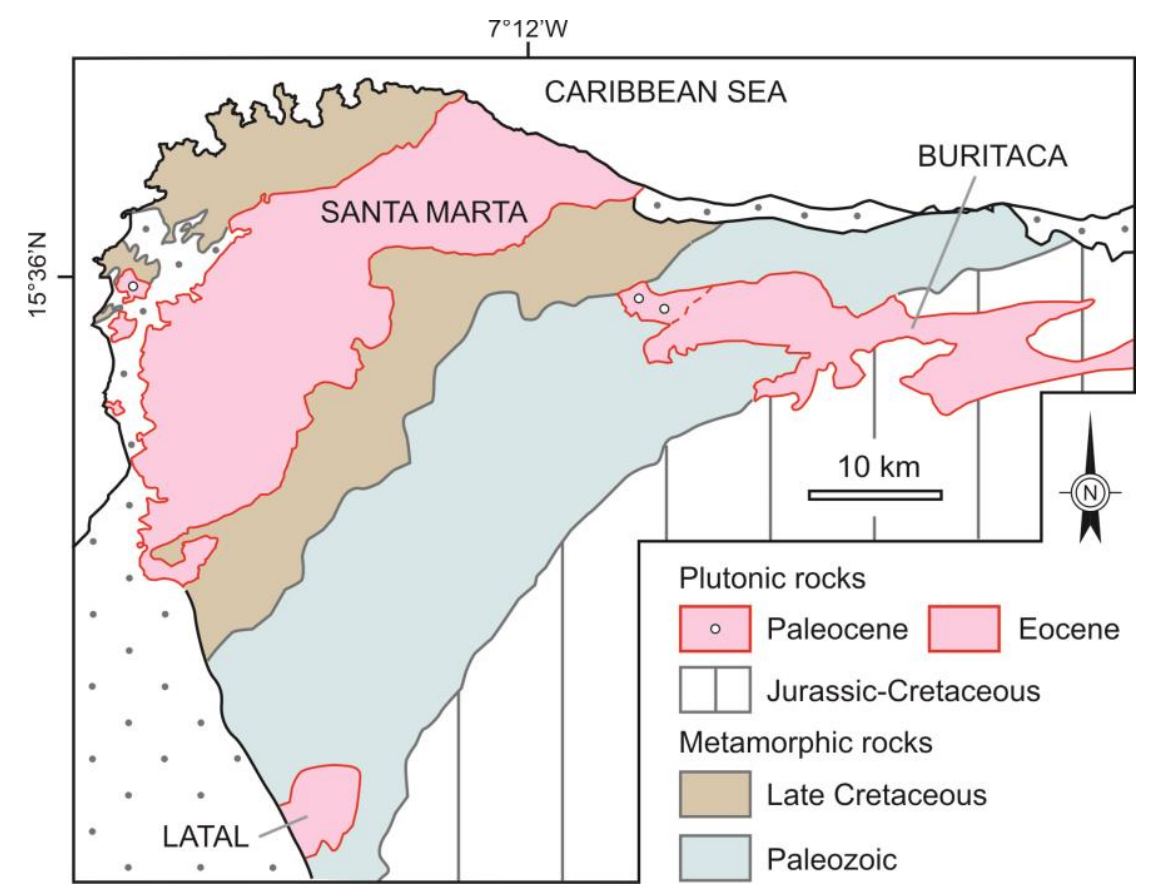

Figure 5.3. Geological map of the eastern part of the Sierra Nevada de Santa Marta

Late, coarse-grained tonalite and quartzdiorite with andesine, calcic amphibole and biotite are found in the northern part of the batholith. Duque (2009) distinguished the coarse tonalitic facies from the main plutonic unit based on the occurrence of abundant amphibolite xenoliths in the former and by field relations that show intrusive contacts of the coarse tonalite in the main plutonic unit. A late magmatic pulse corresponding to the coarse tonalite is supported by zircon $\mathrm{U} / \mathrm{Pb}$ analysis that provided ages in the range of 52-49 $\mathrm{Ma}$ (Fig. 5.4). Uncertainties in the error analysis between the main plutonic unit dated at 58-54 Ma and the late magmatic pulse at 52-49 Ma suggest they are distinct events (Duque, 2009). We present a new U-Pb (SHRIMP) analysis by dating zircon cores and their zoned rims that support multiple magmatic stages during batholith construction. 


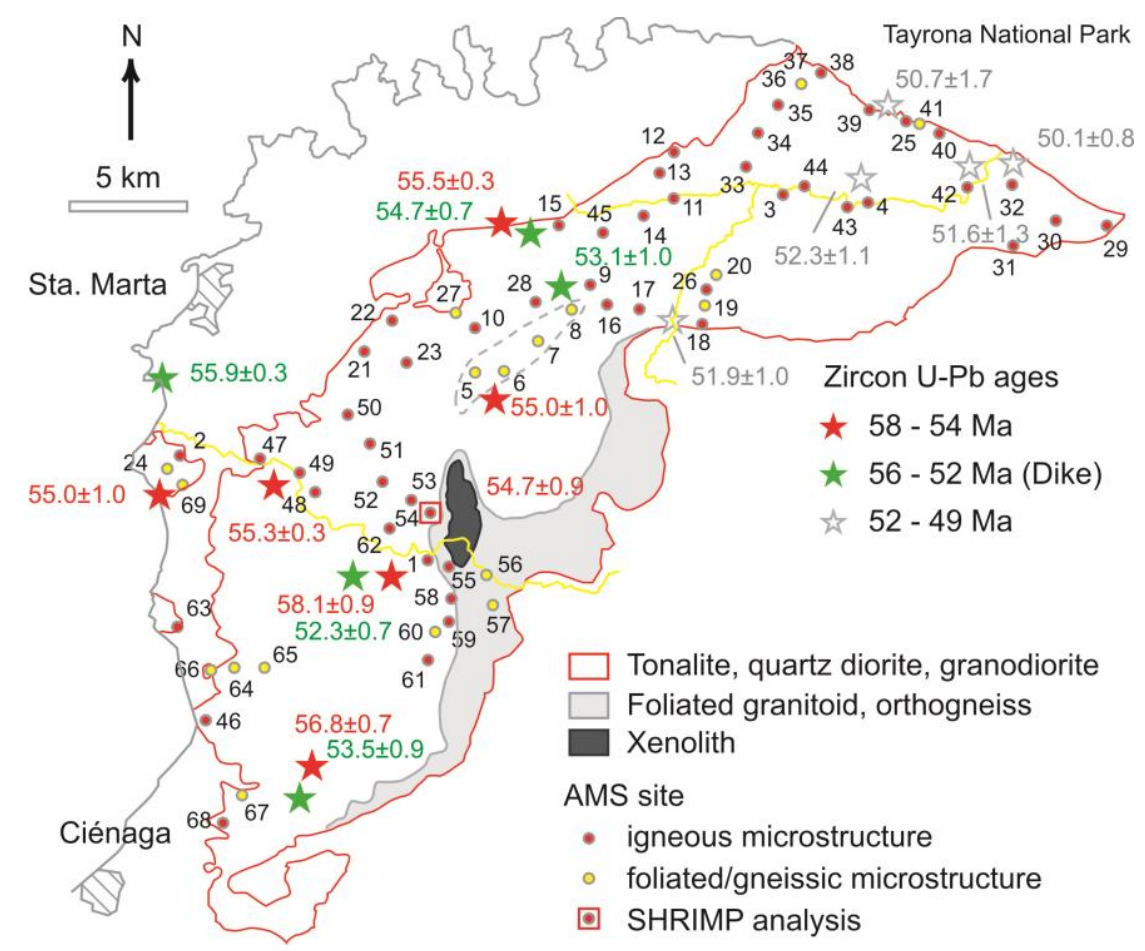

Figure 5.4. AMS sampling sites with the domain with the granitoid with foliated and/or gneissic microstructure (modified from Tschanz et al. (1969). The location of the sites with geochronological determinations after Duque (2009) and Cardona et al. (2011a).

The Buritaca pluton and Latal stock intrude the Paleozoic Sevilla belt and JurassicCretaceous rocks of the central part SNSM block (Fig. 5.3). The Buritaca forms a pluton of 40 $\mathrm{km}$ in width elongated in the E-W direction, while the Latal stock crops out close to the southern margin of the SNSM. Buritaca and Latal plutons consist of tonalites and quartzdiorites with amphibole and biotite. The Buritaca pluton showed zircon U/Pb crystallization ages of $55 \mathrm{Ma}$ and $51 \mathrm{Ma}$ (Duque 2009). No geochronological data is available for the Latal stock and its connection with the Santa Marta and Buritaca plutons is inferred by their similar compositions.

\subsection{U-Pb ZIRCON (SHRIMP) GEOCHRONOLOGY}

\subsubsection{Sampling and methods}

The sample (SM54, see localization on Fig. 5.4) consists of coarse-grained equigranular tonalite with sodic andesine, quartz, hornblende, biotite and K-feldspar $(<5 \%)$. The zircon grains were handpicked after standard crushing and separation procedures. We selected clear euhedral to subhedral grains that were mounted in epoxy together with chips of TEMORA 1 reference zircon (Black et al. 2003). The mount was polished and cathodoluminescence (CL) SEM images were taken for all grains. The analysis of the U-Th- 
$\mathrm{Pb}$ of the zircons was conducted at the Beijing SHRIMP Center (China). The isotopic data were collected in sets of five scans through the masses, and the TEMORA standard was measured after four unknown analysis. The abundances of $\mathrm{U}$, Th and $\mathrm{Pb}$, and the $\mathrm{Pb}$ isotopic ratios were normalized using the SL13 zircon standard. The data reduction was performed using the SQUID Excel macro (Ludwig, 2000), and the statistical assessments were calculated using the ISOPLOT/Excel 3.0 (Ludwig, 2003). The results are reported in Table 5.1 with uncertainties in the isotopic ratios and the ages in data reported at the $1 \sigma$ level and the weighted mean ages as $95 \%$ confidence limits.

\subsubsection{Results}

The zircon grain sizes range between 50 and $300 \mu \mathrm{m}$ in length and show axial ratios (long/short dimensions) mostly from $1.2: 1$ to $3.5: 1$. The zircons have distinct oscillatory zoned dark cores enveloped by light grey phase also displaying concentric oscillatory zone patterns (Fig. 5.5). The overgrowths sometimes cut the oscillatory zoned cores suggesting multiple events of zircon growth. From a total of 19 analyses three are from the zircon cores (spots \#8.1; \#14.1 and \#16.1) and sixteen analyses are from the overgrowths. There is no difference between the ${ }^{204} \mathrm{~Pb} /{ }^{238} \mathrm{U}$ ages of the cores and overgrowths, except in one analysis (spot \#14) in that the core is slightly older (see Table 5.1). By removing three analyses with reverse ages (\#6.1,\#13.1 and \#14.2) and one analysis with an older age (\#9.1) the remaining fifteen analyses form a cluster on the Concordia curve to define a mean ${ }^{206} \mathrm{~Pb} /{ }^{238} \mathrm{U}$ age of 54.7 $\pm 0.9 \mathrm{Ma}$ (Fig. 5.6). This result is consistent with zircon $\mathrm{U}-\mathrm{Pb}$ ages reported in the literature for the Santa Marta batholith and corresponds to the main episode of the batholith construction (Cardona et al. 2010).

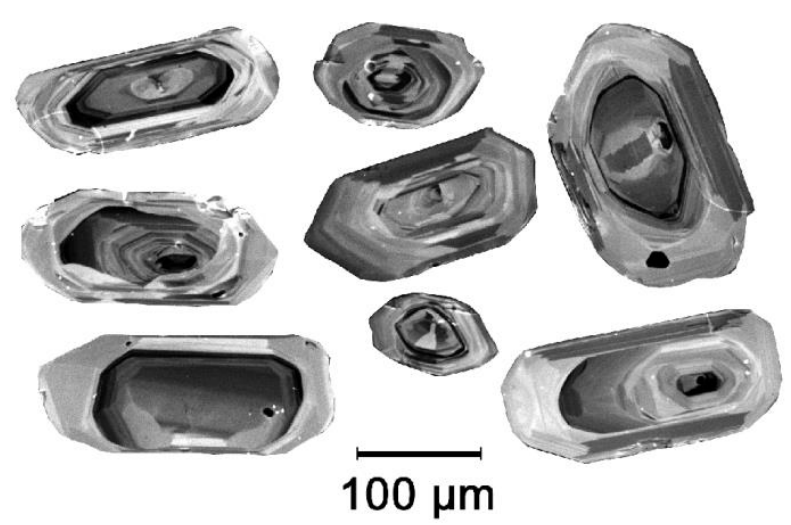

Figure 5.5. Cathodoluminescence images of representative zircons of a horblende-biotite tonalite (sample SM54). Some grains show dark (U-rich) cores (left) enclosed by more luminescent (and low U) rims. Oscillatory zoning typical of magmatic zircons are visible in cores and rims. 


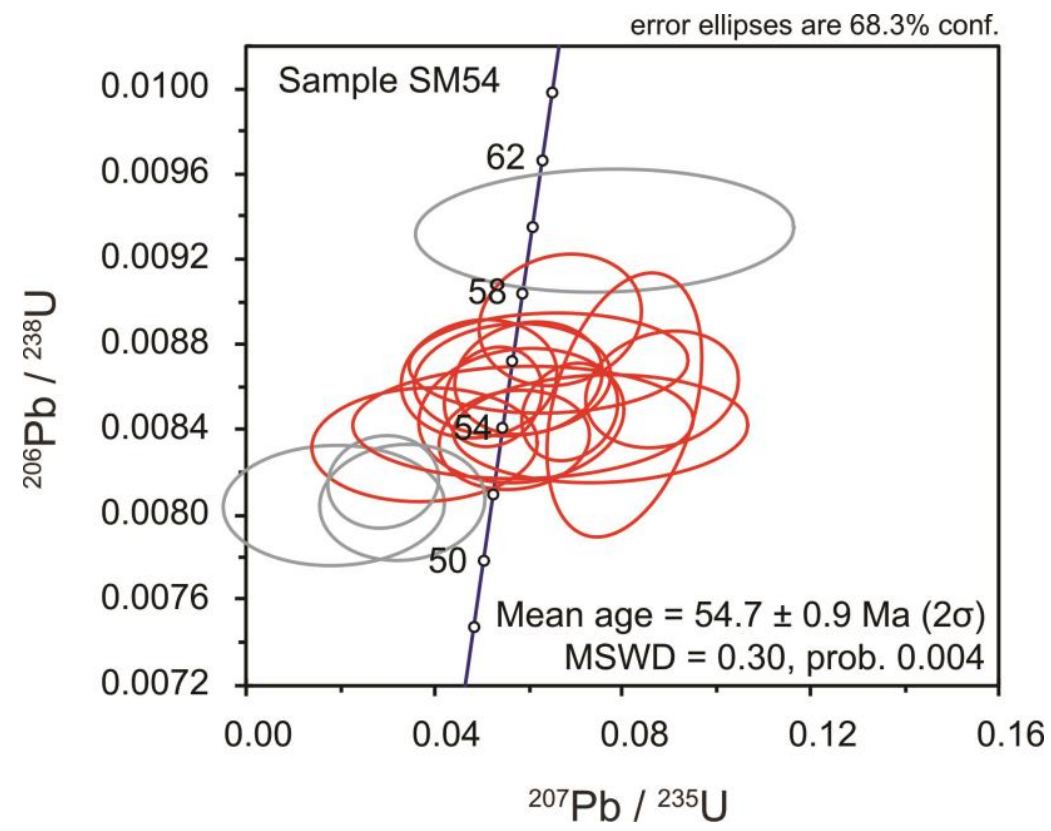

Figure 5.6. Concordia diagram of the hornblende-biotite tonalite, with the zircon age determined by average of the concordant data. Analyses corresponding to the grey ellipses were discarded from the age calculation (see text).

\subsection{ANISOTROPY OF MAGNETIC SUSCEPTIBILITY AND ANISOTROPY OF ANHYSTERETIC REMANENCE}

\subsubsection{Background}

The low-field $\left(\sim 10^{-4} \mathrm{~T}\right)$ anisotropy of magnetic susceptibility (AMS) refers to a material property whereby an external field $(\mathrm{H})$ applied in different directions produces different magnitudes of the induced magnetization $(\mathrm{M})$. The magnetization is related to the applied field by a susceptibility (k) parameter so that $\mathrm{k}=\mathrm{M} / \mathrm{H}$. AMS is defined in terms of a susceptibility ellipsoid which has principal axes along the directions of maximum $\left(\mathrm{k}_{1}\right)$, intermediate $\left(\mathrm{k}_{2}\right)$ and minimum $\left(\mathrm{k}_{3}\right)$ susceptibility (see details in Hrouda, 1982; Borradaile and Henry, 1997). AMS is an intrinsic property of the rock that represents the contribution of the susceptibility anisotropies of all the mineral components and that depends on the shape and degree of alignment (fabric) of their grains.

The anisotropy of anhysteretic remanence (AAR) isolates the contribution of the remanence-bearing minerals, usually magnetite, from that of the whole-rock matrix. An anhysteretic remanence is imparted to a ferromagnetic grain when it is subjected simultaneously to alternating field (AF) and small bias direct magnetic field. Such as AMS, AAR can be described by an ellipsoid of anhysteretic remanence susceptibility $\left(\mathrm{k}_{\mathrm{A}}\right)$ with 
maximum $\left(\mathrm{k}_{1 \mathrm{~A}}\right)$, intermediate $\left(\mathrm{k}_{2 \mathrm{~A}}\right)$ and minimum $\left(\mathrm{k}_{3 \mathrm{~A}}\right)$ principal directions (Jackson, 1991). AAR also permits the isolation of sub-fabrics within the magnetite fabric. Since there is a correlation between the coercivity spectra and the magnetite grain-size (Jackson et al., 1988), it is possible to measure the AAR associated with a particular grain-size using the partial AAR (pAAR). Fine particles, for instance, reach maximum coercivities for high-AF windows while coarser grains are more sensitive to weaker AFs. As magnetite in igneous rocks may crystallize at different times with different orientations, the determination of pAAR allows the investigation of possible overprinted fabrics (eg. Trindade et al., 1999; Usui et al., 2006).

\subsubsection{Sampling and Methods}

Oriented samples were extracted from 69 sites separated from each other by 1-2 km apart (Fig. 5.4). The sites are relatively well distributed on the whole batholith but some areas, mostly to the east and southeast, that were not accessible. Between three and five cores of approximately $8 \mathrm{~cm}$ in length and $2.5 \mathrm{~cm}$ in diameter were collected at each site using a portable gasoline powered drill. The cores were oriented in place with a magnetic compass. In the laboratory each core was cut in standard specimens that were $2.2 \mathrm{~cm}$ in length providing a total of 759 specimens.

The magnetic properties of the samples were studied in the Laboratório de Paleomagnetismo of the São Paulo University. Low-field AMS was determined in a KLY-4 Kappabridge susceptometer that provides the bulk volumetric magnetic susceptibility of the specimen and the principal directions of anisotropy. The intensity of AMS was indicated by the degree of anisotropy $\mathrm{P}=\mathrm{k}_{1} / \mathrm{k}_{3}$ and the symmetry of the ellipsoid by the shape parameter $\mathrm{T}$ $=\left[2 \ln \left(\mathrm{k}_{1} / \mathrm{k}_{2}\right) / \ln \left(\mathrm{k}_{2} / \mathrm{k}_{3}\right)\right]-1$, where $0<\mathrm{T} \leq 1$ correspond to the oblate and $-1 \leq \mathrm{T}<0$ to the prolate ellipsoids. The directions of the susceptibility ellipsoid are $\mathrm{k}_{1}$, quoted as the magnetic lineation, and $\mathrm{k}_{3}$ quoted as the pole of magnetic foliation. The data were statistically evaluated by ANISOFT v.3.2 software that calculates the mean-site AMS parameters (all caps, $\mathrm{K}_{1} \geq \mathrm{K}_{2}$ $\geq \mathrm{K}_{3}$ ) after averaging the data of 6 to 18 specimens by site. The mean-site AMS magnitudes and directions indicated in Table 5.2.

Partial anhysteretic remanent magnetizations of specimens with different low-field magnetic susceptibilities were investigated following the procedures described in Jackson et al. (1988). The specimen is initially demagnetized by tumbling at peak alternating field (AF) of $100 \mathrm{mT}$ using a LDA-3-AMU demagnetizer (AGICO ltd). The partial anhysteretic remanent magnetization (pARM) acquisition consists of applying a steady direct field (DC) of 
between two chosen values of a decaying AF peak (see details in Jackson et al. 1988). pARM was determined by exposing the specimen in an AF peak of $100 \mathrm{mT}$ and a DC field of $0.1 \mathrm{mT}$ with an AF window of $10 \mathrm{mT}$, and the anhysteretic remanence measured in JR6-A spinner magnetometer (AGICO Ltd).

The anisotropy of anhysteretic remanence (AAR) was investigated using the procedures described in McCabe et al. (1985). The specimen is demagnetized by tumbling in a peak AF of $100 \mathrm{mT}$ and the base level magnetization measured in the JR-6A. Then an ARM is induced along a specific specimen axis by applying a decaying AF combined with a DC field and the remanence measured in the magnetometer. The specimen is demagnetized by tumbling and a new anhysteretic magnetization imparted along a different axis. Cycles of demagnetization and anhysteretic magnetization are induced along six different positions and the respective remanence measured in the JR6-A. The magnitude and directions of the remanence can be described by an anisotropy tensor calculated by least squares method using the REMASOFT-W software.

The magnetic mineralogy was investigated through the temperature dependence of the magnetic susceptibility ( $\mathrm{k}-\mathrm{T})$. Representative samples of the batholith were crushed to a fine sand-size, and a small volume fraction measured from $-200{ }^{\circ} \mathrm{C}$ to $700{ }^{\circ} \mathrm{C}$ using a $\mathrm{CS}-3$ furnace/CSL cryostat attached to the KLY-4 Kappabridge. At low temperatures, the magnetic susceptibility was recorded by warming the sample from approximately $-200{ }^{\circ} \mathrm{C}$ to room temperature. From room temperature up to $700{ }^{\circ} \mathrm{C}$ (heating cycle) and back (cooling cycle), $\mathrm{k}-\mathrm{T}$ was measured in an argon environment to prevent oxidation of the sample by atmospheric oxygen in the heating/cooling cycle.

\subsubsection{Magnetic susceptibility and mineralogy}

AMS parameters of the Santa Marta batholith are indicated by the mean arithmetic values (all caps) of the all specimens collected in each site. The bulk magnetic susceptibility $\left(\mathrm{K}=1 / 3\left[\mathrm{~K}_{1}+\mathrm{K}_{2}+\mathrm{K}_{3}\right]\right)$ ranges from 0.024 to $15.7 \times 10^{-3} \mathrm{SI}(\mathrm{mSI})$ and the anisotropy degree $\left(\mathrm{P}=\mathrm{K}_{1} / \mathrm{K}_{3}\right)$ from 1.034 to 1.51 (Fig. 5.7A). Susceptibility magnitude is low $(\mathrm{K}<1 \mathrm{mSI})$ in 29 sites with the respective degree of anisotropy ranging from 1.03 to 1.12 (average of 1.07). Moderate $(1<\mathrm{K}(\mathrm{mSI})<10)$ and strong $(\mathrm{K}>10 \mathrm{mSI})$ magnetic susceptibility magnitudes are recorded in 40 sites. These sites have $\mathrm{P}$ values higher (average of 1.25) and more variable $(1.085<\mathrm{P}<1.513)$ compared to those with low susceptibility. The shape of the AMS ellipsoids is dominantly neutral to oblate $(T \geq 0)$ with a few prolate ellipsoids $(T<0)$ found 
principally in the specimens with low susceptibility (Fig. 5.7). There is no relation between the $\mathrm{P}$ parameter and a particular sector of the pluton, although ellipsoids with neutral to oblate shapes are recorded mostly the northern part of the intrusion.
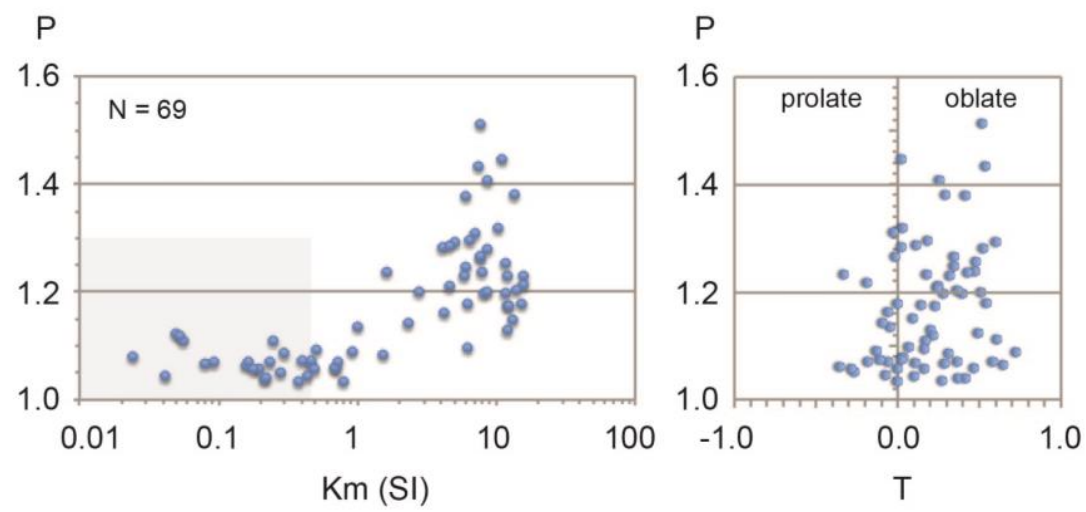

Figure 5.7. Relation between the mean-site magnetic susceptibility $\left(K_{m}\right)$, degree of anisotropy $(P)$ and shape $(T)$ of the AMS ellipsoid.

$\mathrm{k}-\mathrm{T}$ curves for specimens with moderate and high susceptibilities show similar and very simple shapes. They display a net Verwey transition at c. $-160{ }^{\circ} \mathrm{C}$ and a strong drop of susceptibility close to $580{ }^{\circ} \mathrm{C}$ (Fig. 5.8A, B). The susceptibility at the end of cooling cycle is a rather higher that in the heating cycle at room temperature indicating that new magnetic phases were produced on heating. Similar results are typical of coarse (Ti-poor) magnetite and have been documented in granitoid rocks of different ages and tectonic settings (Salazar et al., 2008; Henry et al., 2009; Ferré et al., 2012).

The Verwey transition becomes poorly defined (Fig. 5.8C) or disappears at low temperature (Fig. 5.8D) while the susceptibility decreases progressively as temperature increases in specimens with low susceptibility. The poorly defined, smooth Verwey transition suggests small amounts and/or an oxidized magnetite (Ozdemir et al., 1993) while the decrease of magnetic susceptibility with temperature indicates the strong contribution to the bulk magnetic susceptibility of the paramagnetic phases. The curves are irreversible at room indicating that some new magnetic phases were formed in the heating and cooling cycle. 

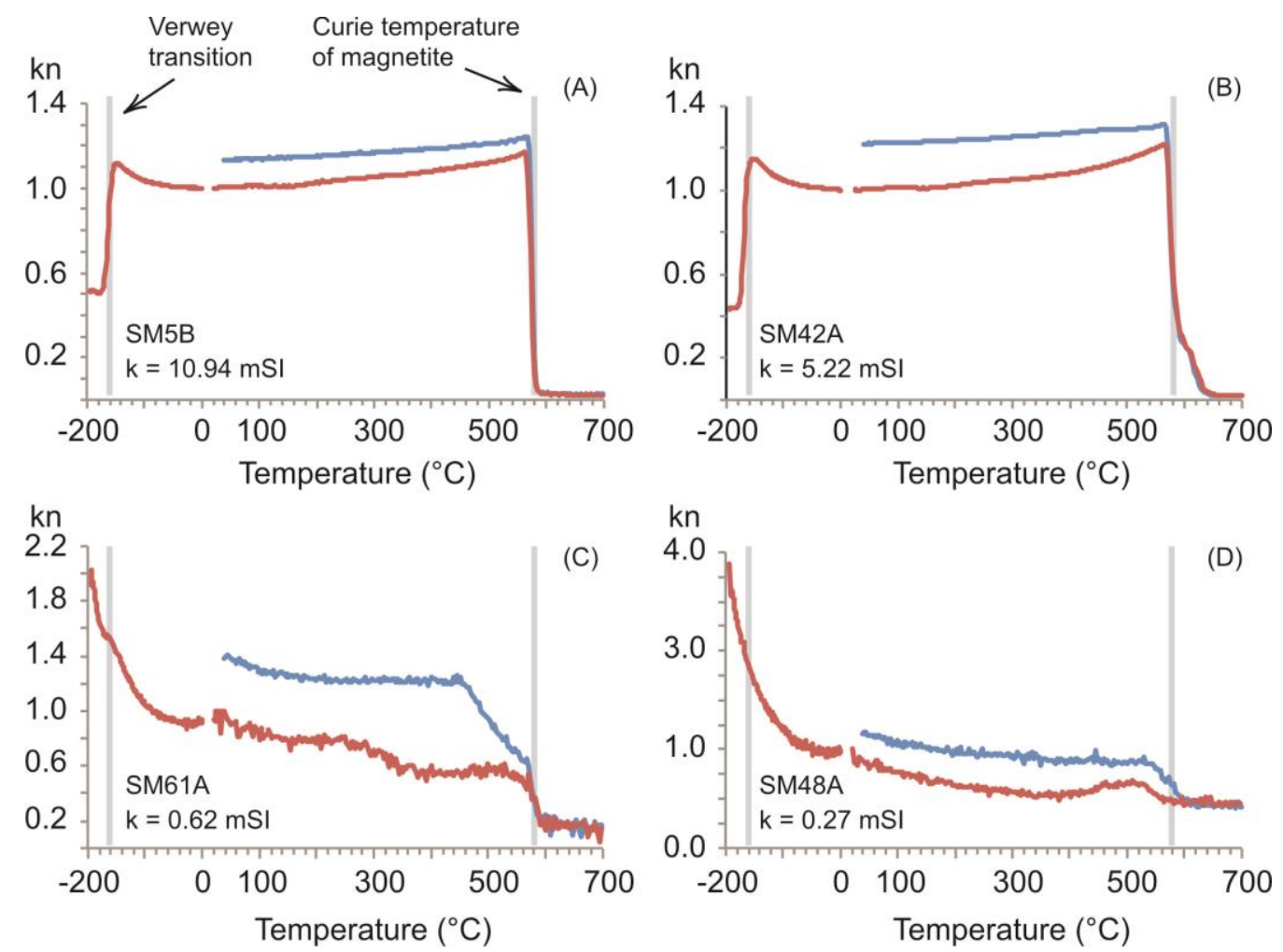

Figure 5.8. Dependence of the magnetic susceptibility with temperature for representative samples of the Santa Marta batholith.

\subsubsection{Anisotropy of magnetic susceptibility}

The dominant oblate AMS ellipsoids indicate that the foliation is the best-defined magnetic fabric element of the Santa Marta batholith. Their dips vary mostly to the northwest, southeast and south, and locally to the north and northeast (Fig. 5.9). Based on the foliation trend we define two major structural domains; (i) a northern domain in that foliation strikes mainly in the N-S direction, and (ii) a southern domain in that foliation strikes to NW or NE directions. These domains, or lobes, are divided by a set of E-trending foliations (dashed line in Fig. 5.9) that are also found in the northeastern margin of the batholith.

The northern lobe is characterized by neutral to oblate AMS ellipsoids $(0.0 \leq \mathrm{T} \leq 0.5)$ and degree of anisotropy between 1.04 and $1.51($ Pmean $=1.23)$. The foliation shows variable dips to the southeast or to the northwest and is usually associate with a NE-trending gentle plunge lineation. In contrast, the northeast margin shows mostly E- to NW-trending foliations. The lineations vary from subhorizontal to down-dip in agreement with the dominant oblate $\left(\mathrm{K}_{1} \sim \mathrm{K}_{2}>\mathrm{K}_{3}\right)$ ellipsoid.

AMS of the southern lobe differs from the northern lobe by ellipsoids that vary from prolate to oblate $(-0.35<\mathrm{T}<0.72)$ and a weaker anisotropy (Pmean $=1.12)$. The foliation 
shows moderate to gentle dips in the center of the lobe (Fig. 5.9) and strikes that tend to be parallel to the lobe elongation. The lineation aligns mostly in the E-W and N-S directions.

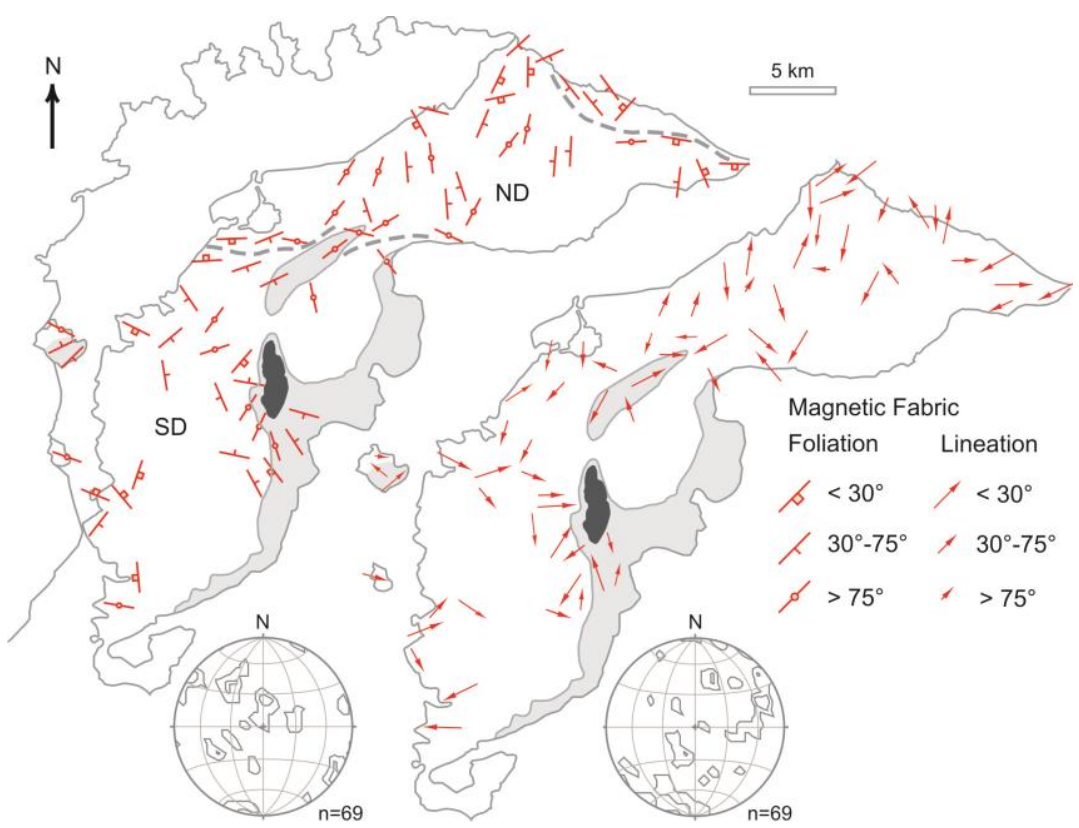

Figure 5.9. Magnetic fabric (foliation and lineation) and domains where the rock microstructure is foliated and/or gneissic (grey area). Dashed line corresponds to the corridors where the foliation trend is nearly E-W. Stereonets of the magnetic lineation (right) and pole of the magnetic foliation (Schmidt diagrams, lower hemisphere; contours of 2\%, 4\% / 1\% area). Black; xenolith. ND and SD; northern and southern domain.

\subsubsection{Anisotropy of Anhysteretic Remanence}

The coercitivity spectra of selected specimens with different magnitudes of magnetic susceptibility are presented in figure 10 . Specimens with strong susceptibility show typically a unimodal distribution with a simple peak by $10 \mathrm{mT}$, with the coercivity practically vanishing after $30 \mathrm{mT}$. This indicate that the low coercivity, coarse magnetite grains dominate the remanence of specimens with strong magnetic susceptibility (Jackson et al., 1988). In contrast the specimens with very low magnetic susceptibility $(\mathrm{k} \leq 0.5 \mathrm{mSI})$ show a noisy spectra but with a distinct peak of coercivity in the range of 40-80 $\mathrm{mT}$. The remanence of specimens with very low magnetic susceptibility is therefore dominated by fine-grained, highly coercive magnetite (Jackson et al., 1988). Coercivity curves of specimens with moderate susceptibility displays a grain size bimodality, with a peak about $10 \mathrm{mT}$ and another between $40 \mathrm{mT}$ and 70 mT. Specimens with moderate susceptibility show therefore two population of magnetite, a low coercive coarse fraction and a subordinate more coercive formed by finer grains. 


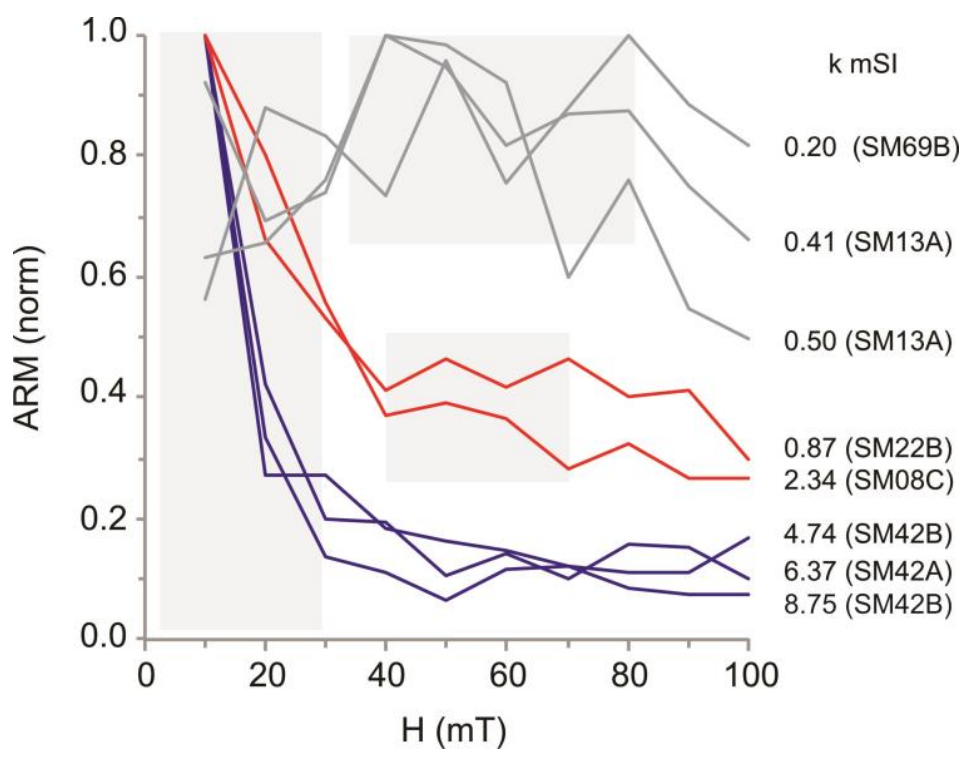

Figure 5.10. Coercivity spectra for samples with different susceptibility magnitudes $\left(\mathrm{k}, 10^{-3} \mathrm{SI}\right)$. Grey areas indicate the windows chosen to determination of partial anisotropy of anhysteretic remanence. $\mathrm{H}$, induced field, ARM; normalized anhysteretic remanent magnetization.

The $\operatorname{pAAR}_{(0-30)}$ ellipsoid of the specimens with moderate and strong susceptibility is similar to AMS both in shape and orientation of their principal directions (Fig. 5.11). The AMS and $\operatorname{AAR}_{(0-30)}$ ellipsoids are oblate (SM42, SM8) or prolate (SM59) and their principal directions groups to define a lineation and a foliation. A weak obliquity between the $\mathrm{K}_{2}$ and $\mathrm{K}_{3}$ directions is observed in the sample SM59, which is attribute to the prolate shape $(\mathrm{T}=-$ $0.19)$ of the $\operatorname{AAR}_{(0-30)}$ ellipsoid. These results indicate that the coarse magnetite grains control the anisotropy of magnetic susceptibility of the specimens with moderate and strong susceptibility. Anisotropy of remanence for the more coercive fractions remain similar to AMS (Fig. 5.11; SM8) or shows principal directions that tend to scatter (SM59) although the lineation defined by $\mathrm{AAR}_{(50-70)}$ tends to group in a direction parallel to the lineation provided by $\mathrm{AMS}$ and $\mathrm{AAR}_{(0-30)}$. 

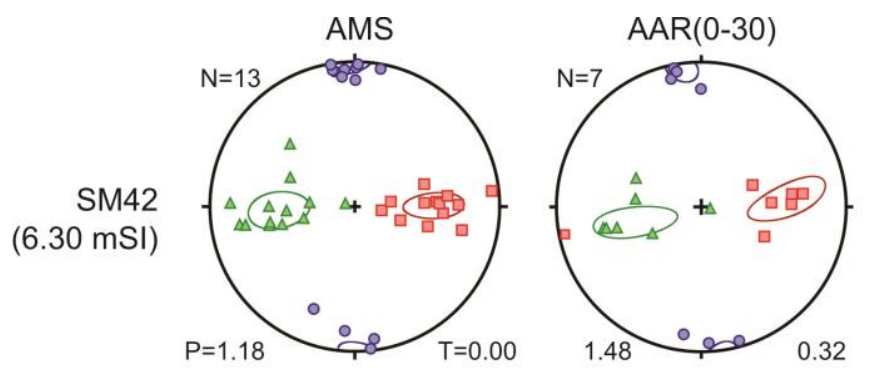
AMS / AAR
$\square$ kmax
$\triangle$ kint
- $\mathrm{kmin}$
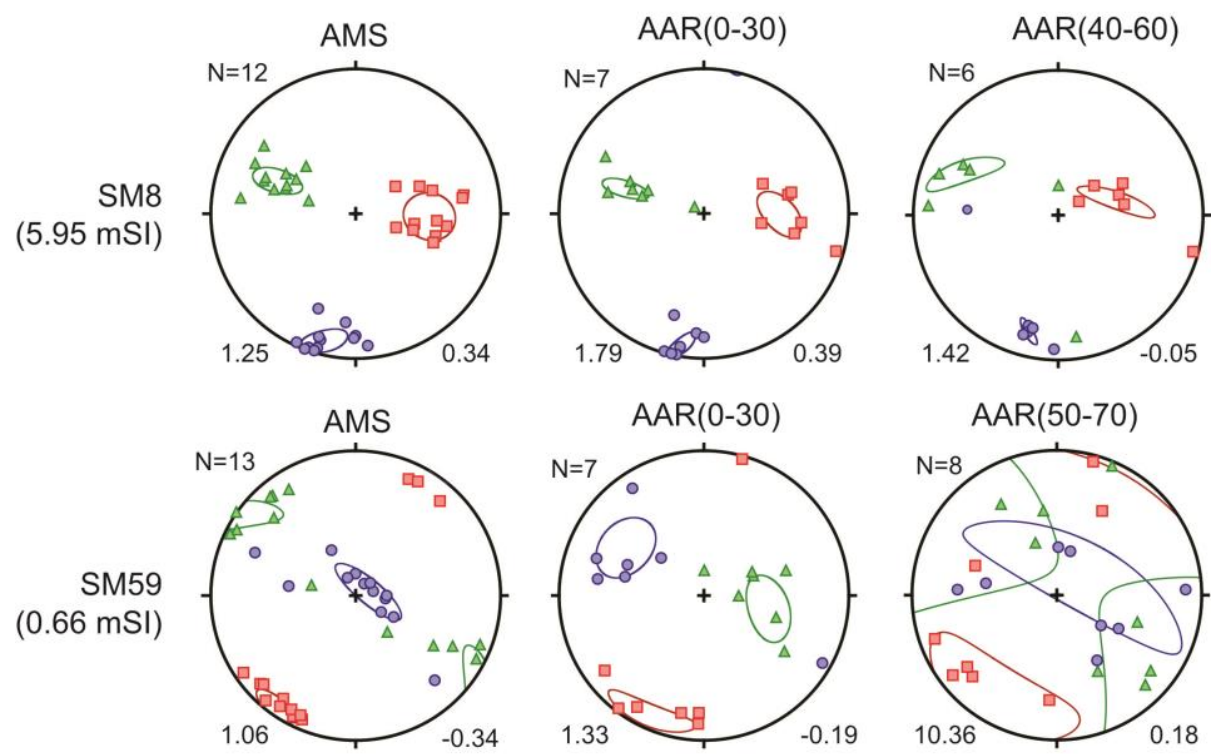

Figure 5.11. Stereograms (lower hemisphere) of the principal directions of AMS and partial AAR for sites with moderate to strong magnetic susceptibility magnitudes.

Different ellipsoid shapes and/or distribution of principal directions are recorded in the sites with very low susceptibility (Fig. 5.12). Although slightly oblique, only the foliation defined by AMS and AAR keeps a good correspondence. A switch between the maximum and intermediate principal directions of AMS and AAR (SM36) probably originates from the oblate distribution of AMS principal directions coupled with different carriers of the magnetic fabric, mostly the paramagnetic silicates for AMS and fine magnetite for AAR. 

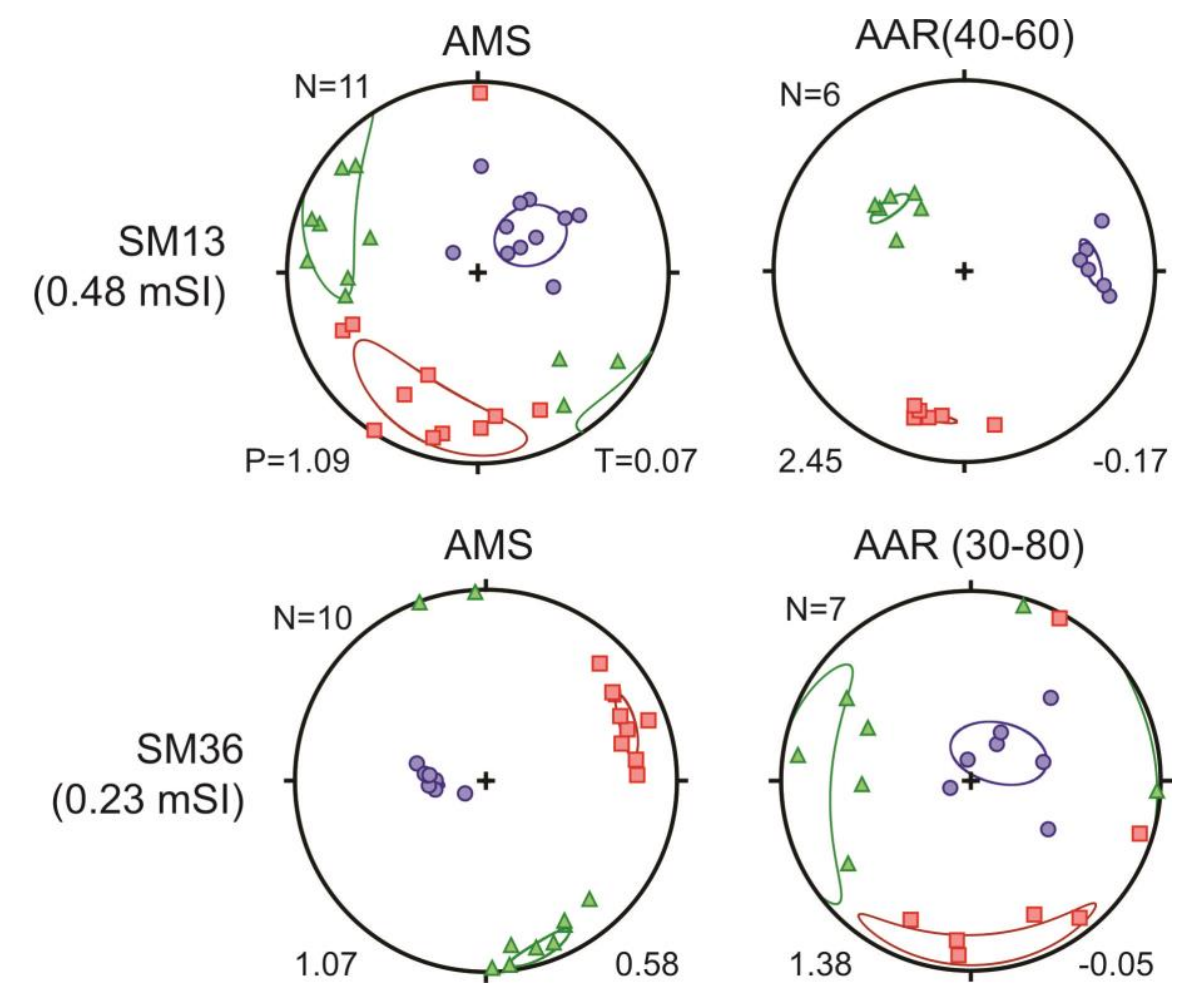

Figure 5.12. Stereograms (lower hemisphere) of the principal directions of AMS and partial AAR for sites with low magnetic susceptibility magnitudes (symbols as Fig. 11).

\subsection{DISCUSSION}

\subsubsection{Significance of magnetic fabrics}

The dependence of susceptibility with temperature (k-T) combined with the coercitivity spectra indicate the mineral that control the susceptibility signal in the Santa Marta batholith is Ti-poor magnetite. For specimens with $\mathrm{k}>0.55 \mathrm{mSI}$ (65\% of the stations) the Curie temperature at c. $580{ }^{\circ} \mathrm{C}$, well-defined Verwey transition at c. $-160{ }^{\circ} \mathrm{C}$ and rapid acquisition of remanence in applied fields below $30 \mathrm{mT}$ indicate a coarse, multidomain magnetite (Muxworthy and McClelland, 2000). Petrographic examination shows that magnetite grain size normally ranges between $50 \mu \mathrm{m}$ and $500 \mu \mathrm{m}$ and occur associate with titanite, amphibole and biotite. For specimens with $\mathrm{k}<0.5 \mathrm{mSI}$ the Verwey transition becomes poorly defined or disappears for $\mathrm{k}<0.35 \mathrm{mSI}$. Moreover, between $-150{ }^{\circ} \mathrm{C}$ and approximately $350{ }^{\circ} \mathrm{C}$ the susceptibility magnitude decreases progressively as the temperature increases, indicating an important contribution to the paramagnetic minerals to the magnetic susceptibility (Rochette et al., 1987). However, even in the specimens in that the Verwey transition is not detected and k-T is governed by the paramagnetic fraction, the ARM experiments find the presence of magnetite. These highly coercive grains are not observed in 
thin-sections, which suggest they must occur as inclusions within the silicates. Moreover, the directional correspondence between principal directions AMS and AAR indicates that the size of the ferrimagnetic inclusions is above the single domain threshold of magnetite, discarding therefore the effect of inverse fabrics in AMS results (Rochette et al., 1992).

Shape and orientations of the AMS and $\mathrm{AAR}_{(0-30)}$ ellipsoids are similar to show that AMS depends on the magnetostatic anisotropy of coarse, low coercive magnetite grains. However, between approximately $0.5<\mathrm{k}(\mathrm{mSI})<2$ a subordinate high coercivity fraction can be detected along with the low coercive grains. The orientations of the principal directions of AMS, $\mathrm{AAR}_{(0-30)}$ and $\mathrm{AAR}_{(40-70)}$ agree to each other to indicate that the fractions with different coercivities, i.e., different magnetite grain sizes, are coaxial. Recent experimental evidence (Arbaret et al., 2013) and X-ray tomography (Schopa et al., 2015) have been confirming the remarkable consistency between the AMS signal defined by magnetite preferred orientation and the rock fabric elements, notably the lineation and foliation. We conclude, therefore, that the magnetic foliation recorded in the Santa Marta batholith tracks fairly well the planar magmatic fabric acquired when the magma was crystallizing.

For specimens with very low magnetic susceptibility the contribution of magnetocrystalline anisotropy of paramagnetic silicates to the bulk susceptibility becomes important. The agreement between the minimum principal directions of AMS and AAR indicates that the crystallographic directions of the host silicates would control the distribution of magnetite inclusions. Indeed fine magnetite inclusions in plagioclase (Usui et al., 2015) and micas (Borradaile and Werner, 1994; Martin-Hernandez and Hirt, 2003) appear to be a common feature in many intermediate to felsic plutonic rocks due to exsolution in silicate minerals upon on cooling of magma (Trindade et al., 1999; Usui et al. 2006; Salazar et al., 2013). Furthermore, late-magmatic fluids interacting with the silicate mush may also form fine oxides (e.g. Raposo and Gastal, 2009; Nedelec et al., 2015), which in some cases can be able to disorganize the magnetic fabric (Just et al., 2004; Archanjo et al., 2009). Despite of the potential problems that exsolution and/or hydrothermalism can carry to the AMS interpretations, fine ferrimagnetic particles may also be a proxy for the preferred orientation of the silicates if the inclusions are aligned due to the host lattice. We therefore consider that equivalence between AMS and AAR for the most coercive fractions combine with the $\mathrm{k}-\mathrm{T}$ results indicates that: (i) the magnetic fabric of the very low susceptibility sites records the preferred orientation of the paramagnetic silicates, and (ii) the absence of superposed subfabrics with different orientations in the Santa Marta batholith. 


\subsubsection{Emplacement structures and tectonic implications}

Figure 13 integrates the trend of magnetic foliations defined by AMS, the domains in that the rock texture varies from foliated to gneissic, the metamorphic foliation of the wallrocks (Tschanz et al., 1969) and the sectors of the batholith corresponding to the late magmatic pulses indicated by zircon U-Pb ages (Duque, 2009; Cardona et al., 2011a). This information allows proposing an emplacement model in which magma crystallized when the magmatic arc was deforming by dextral shear. P-T data from the metapelitic wall rocks and Al-in horblende from the tonalite suggest a depth of emplacement of c. $16 \mathrm{~km}$ (Cardona et al. 2011b; Zuluaga and Stowell, 2012). The batholith is divided approximately in a half by Easttrending magnetic foliations and lineations which we interpret as recording an synthetic shear band ( $\mathrm{C}^{\prime}$-surface; dashed line in Fig. 5.13) related to an NE-trending shear C-plane. These extensional structures have been reproduced in analogue models simulating the deformation of partially molten aggregates, with the melt channeled into the shear band during their propagation (Rosenberg and Handy, 2000).

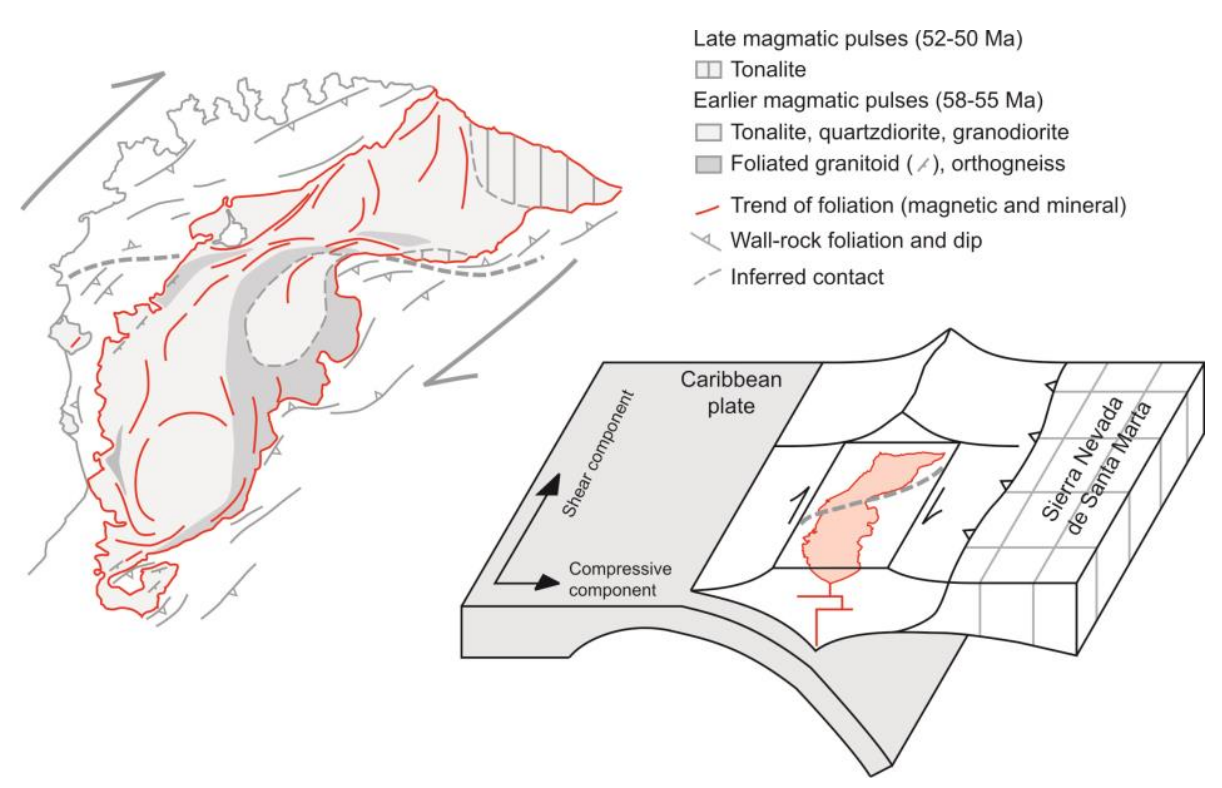

Figure 5.13. Tectonic model of the Santa Marta batholith (upper left) combining the trend of magnetic foliation (red lines) and the metamorphic fabric of the host-rocks (after Tschanz et a., 1969). Dashed lines correspond to the synthetic shear bands originated by the regional strain field dominated by dextral shear. The shear component is transmitted to the magmatic arc (lower right) by the oblique subduction of the Caribbean plate.

The orientation of magnetic foliations in the northern lobe of the batholith tend to be $\mathrm{N}-\mathrm{S}$ parallel to the maximum flattening plane (S-surface) of the shear deformation, except on its northeastern margin in that foliations tend to be aligned in the NW-SE direction. Magnetic lineations show two contrasting directions, parallel to the $\mathrm{N}$-trending foliations or 
perpendicular plunging moderately to the east or to the west. The different directions of the lineations are attributed to the dominant oblate AMS ellipsoid that characterizes the northern lobe of the batholith. The southern lobe shows foliations nearly parallel to the contact with the wall-rocks where the tonalite is foliated or display a gneissic texture. A semi-concentric foliation pattern can be traced to the south of the batholith that could indicate a possible magmatic feeder zone or, alternatively, be originated by the shearing deformation along the wall-rock contact.

Five U-Pb zircons ages in the range of 58-54 Ma (Cardona et al., 2011a; Duque, 2009; this study) come from the southern lobe and one from the northern lobe. This magmatic event must correspond to the main phase of the batholith construction. Late porphyritic to equigranular felsic dikes provided $\mathrm{U}-\mathrm{Pb}$ ages in the range of 56 and $52 \mathrm{Ma}$, and are attributed to brittle deformation of still molten igneous body submitted to shear stress. Four samples collected in the north domain close to the Tayrona Park yielded zircon U-Pb ages between 52 and $50 \mathrm{Ma}$. One sample situated to the east of the E-trending corridor in the middle part of the batholith also provided a zircon $\mathrm{U}-\mathrm{Pb}$ age of $52 \mathrm{Ma}$. Uncertainties in the error analysis show that the earlier magmatic pulses and the late pulse are distinct, which indicates that the Santa Marta is a composite batholith formed over a relatively long-lived magmatic source above a subducting slab (Coleman et al., 2004; Matzel et al., 2006; Schaltegger et al., 2009). Although the younger magmatic pulse can be locally recognized penetrating an older plutonic unit, such as described by Duque (2009), their similar composition, color and grain sizes make very difficult to individualize these units on the batholith scale. We inferred the contacts of these magmatic units by the location of the $\mathrm{U}-\mathrm{Pb}$ analysis combined with the trend of the magnetic foliations. The late tonalite shows the same East-trending elongation of the Buritaca pluton that also provided a zircon $\mathrm{U}-\mathrm{Pb}$ age in the range of $51 \mathrm{Ma}$ (Duque, 2009). By considering the similar age and compositions between Santa Marta and Buritaca plutons, we propose that late reactivations $C^{\prime}$-planes would have assisted the nucleation and emplacement of the late magmatic pulses.

Palinspatic reconstructions suggest that at least $1.000 \mathrm{~km}$ dextral offset between the southern Caribbean and northern South America plates between 84 and $46 \mathrm{Ma}$, as well estimate that c. $1500 \mathrm{~km}$ of the Caribbean lithosphere has been subducting beneath Colombia and Venezuela since late Cretaceous (Kennan and Pindell, 2009). Part of the continental deformation related to the interactions between the two plates has been accommodated along the Romeral fault system. The shear movement parallel to the magmatic arc would have 
assisted the ascension and emplacement of the Santa Marta and Buritaca batholiths probably exploiting the host-rock extensional structures. Evidence for ascent fabrics and/or body structures (feeder zones, internal convection) were not positively identified, which indicated that arc-parallel shear deformation outlasted the crystallization of the magmas and controlled the shape and orientation of the magnetic fabrics.

\subsection{CONCLUSIONS}

Anisotropy of susceptibility and remanence indicate that magnetic fabrics of the Santa Marta batholith record the dextral shear deformation related to the oblique convergence of the Caribbean plate against the South American continental plate. The magmatism extended for approximately $10 \mathrm{Ma}$ with the crystallization of tonalites, quartzdiorites and granodiorites in at least two main igneous pulses. The older one, between 58 and $54 \mathrm{Ma}$, corresponds to the main event of batholith construction. A SHRIMP analysis of the zircon U-rich cores and zoned rims from a tonalite provided a mean age $54.7 \pm 0.9$ Ma that support an Early Eocene age for main event of magmatism. The shear deformation divides the batholith nearly in a half by East-trending magnetic structures attributed to a synthetic extensional shear band related to a NE-trending arc-parallel shear plane. Such extensional structures would have been reactivated to assist the emplacement of the younger magmatic pulses at c. $50 \mathrm{Ma}$. The shear deformation combined with arc-normal shortening imparted a dominant oblate AMS ellipsoid and magmatic to solid-state fabrics foliations parallel to the wall-rock contacts and oblique fabrics close to the principal flattening plane of the strain ellipsoid. Investigations in the magnetic subfabrics using partial anisotropy of anhysteretic remanence showed that the coarse and fine magnetite grains are coaxial to the AMS principal directions. Magnetic fabrics, therefore, record the finite strain imposed by the long-lived shear deformation in the plate margin. Such a deformation recorded in Late Cretaceous forearc sequences that accomodated the Santa Marta batholith was localized in the continental suture that southward juxtaposed the Central and Western Cordilleras. 


\section{Capítulo 6}

\section{Discussão}

O estudo do registro magmático, o detalhamento das idades de cristalização e as fontes dos magmas, além do reconhecimento das relações de campo com as unidades adjacentes, tem uma importância fundamental no estudo do magmatismo de arco. Isto porque os eventos tectônicos ao longo de um intervalo de tempo numa margem convergente são registrados através de variações geoquímicas das rochas plutônicas, o que permite traçar com relativa precisão a evolução tectônica de uma região.

A área de investigação deste projeto abrangeu um intervalo de tempo onde importantes eventos tectono-magmáticos moldaram a Cordilheira Central da Colômbia, como discutido nos capítulos 2, 3, 4 e 5. Foi abordada a formação do embasamento cristalino Permo-Triássico afetado pela intrusão de rochas plutônicas no Mesozóico associado a um metamorfismo regional no Jurássico, finalizando com a intrusão de rochas graníticas de afinidade adakítica no Eoceno. Assim, é possível traçar na Cordilheira Central dos Andes Colombianos uma linha de eventos tectono-magmáticos entre o Permiano e o Eoceno que registram diferentes cenários de extensão e compressão na margem continental relacionados com os processos de subducção acresção.

Os vestígios da separação do Pangea têm sido reconhecidos com precisão na margem oeste dos Andes do Norte (Martens et al., 2014; Spikings et al., 2015). Na Colômbia, esses vestígios foram tradicionalmente identificados a oeste da Falha Otú-Pericos, agrupados no denominado Terreno Tahamí, que é separado de um embasamento de idade Grenvilliana a leste e que constitui o denominado Terreno Chibcha (Restrepo et al., 2011; Martens et al., 2014 Vinasco et al., 2006). Nossos dados permitiram identificar rochas de idade permiana e triássica também a leste da falha Otú-Pericos (Cochrane et al., 2104a; Spikings et al., 2015) que redefinem parte do embasamento anteriormente atribuído ao Grenvilliano como de idade Permo-Triássica (Capítulo 2). Isto sugere uma extensão maior do embasamento PermoTriássico na Cordilheira Central, e uma redefinição do cinturão Grenvilliano na Colômbia, além de questionar o papel da Falha Otú-Pericos como limite de terrenos tectonoestratigráficos. O significado do evento de colisão que reune os Terrenos Tahamí e Chibcha seriam para-autóctones em relação à margem W da América do Sul. O registro da separação 
do Pangea é constituído por ortognaisses e anfibolitos com idades entre ca. 268-239 Ma, e que têm uma assinatura de $\varepsilon_{\mathrm{Hf}}$ inicial entre $-0,1$ e $-2,5$ sugerindo uma crosta continental como fonte do protólito. Para os anfibolitos triássicos, o $\varepsilon_{\mathrm{Hf}}$ inicial é de $+9,2$ até $+10,9$ indicando uma fonte mantélica juvenil. Esses dados, quando comparados com rochas da mesma natureza em outras localidades de ambos os lados da Falha Otú Pericos e dos Andes Equatorianos, são isotopicamente similares às reportadas por Cochrane et al. (2014a) e Spikings et al. (2015). Este conjunto de rochas constitui um magmatismo bimodal de rifte numa margem em subducção no Permo-Triássico, e seguido pelo começo da subducção do proto-Pacífico na margem oeste da América do Sul (Cardona et al., 2010; Villagómez et al., 2011; Cochrane et al., 2014a).

O começo de subducção no Jurássico Inferior, a aproximadamente 200 Ma marca o início de uma intensa e contínua atividade magmática (Aspden et al., 1987; Bustamante et al., 2010; Leal-Mejía, 2011; Cochrane et al., 2014) que se estende até o Cretáceo Inferior (Capítulo 3). O magmatismo é distribuído ao longo da margem leste da Cordilheira Central, incluído a Sierra Nevada de Santa Marta no Caribe Colombiano, formando batólitos de composição variando entre granito até diorito, e com um vulcanismo presente pelo menos nas primeiras etapas da atividade plutônica (Zapata et al., 2016). As características geoquímicas deste magmatismo são típicas de um arco magmático continental, tais como as anomalias negativas de $\mathrm{Nb}$ e Ti, e uma alta relação LREE/HREE, detalhadas no Capítulo 3.

No intervalo entre aproximadamente 170 e 129 Ma, vários eventos sugerem que o regime de subducção mudou de um ambiente extensivo para compressivo, possivelmente associado com mudanças no mergulho da placa em subducção, além da progressiva obliquidade da convergência. A compilação de idades de cristalização U-Pb (Capítulo 3) mostra que as primeiras fases de magmatismo de arco são as mais volumosas, mas a partir de 170 Ma, o volume de magma começa a decrescer. Isto está registrado também na distribuição de idades U-Pb em zircões detríticos do Leste Colombiano (Fig. 3.11: Capítulo 3), e pela evidente diminuição da área de exposição dos plútons mais jovens. Uma característica geoquímica importante do magmatismo neste período é que os isótopos de Hf e $\mathrm{Nd}$ mostram uma tendência mais juvenil nas rochas mais jovens, o que foi interpretado como produto de um slab roll-back (Cochrane et al., 2014). No presente trabalho, entretanto, é associado com um balanceamento da fusão de basalto e sedimentos ao longo do tempo, no qual se tem uma diminuição progressiva do segundo componente associado a crescente obliquidade da convergência. $\mathrm{O}$ regime de convergência extremadamente obliqua poderia ter 
sido a causa da interrupção do magmatismo em ca. 130 Ma (Capítulo 3), similar ao descrito na América Central por Rooney et al.(2015).

No final do magmatismo, em torno de 165 Ma, um importante evento de metamorfismo regional foi registrado na Cordilheira Central (Blanco-Quintero et al., 2014). Este evento é uma indicação adicional da compressão que caracterizou o final do magmatismo mesozóico da Colômbia. O evento metamórfico é caracterizado em rochas de composição pelítica e máfica que atingiram da fácies xisto verde até anfibolito $\left(550-580{ }^{\circ} \mathrm{C}\right.$ e 8 kbar: Blanco-Quintero et al., 2014). Idades U-Pb obtidas em zircões detríticos nas rochas metapelíticas são indicativas de uma bacia deposicional jurássica tendo como embasamento rochas permo-triássico situadas a oeste do cinturão magmático jurássico. A fonte dos zircões detríticos dos metapelitos, embora as idades jurássicas sejam comuns nos Andes do Norte (Colômbia e Equador), são similares as composições isotópicas de Hf de rochas intrusivas aflorantes no Peru (Boekhout et al., 2012). O zircão detrítico mais jovem apresentou uma idade de $162 \mathrm{Ma}$, enquanto a idade do metamorfismo determinado em micas através do sistema Ar-Ar é de 158-147 Ma. (Blanco-Quintero et al., 2014).

Uma etapa de convergência oblíqua, sem magmatismo granítico, é registrada no intervalo entre 129 e 90 Ma, que marca a idade de cristalização do último pluton (stock de Mariquita), e a intrusão do primeiro granitóide depois do hiato no magmatismo, respectivamente. Os acontecimentos durante o mencionado hiato magmático, além das primeiras manifestações de magmatismo relacionado com o proto-Caribe, não fizeram parte deste estudo. Contudo, para contextualizar os eventos eocênicos, é possível mencionar que este intervalo caracterizou-se pela reaparição do magmatismo de arco na margem $\mathrm{W}$ da Colômbia entre 90 - 70 Ma (Leal-Mejía et al., 2011; Villagómez et al., 2011), e a colisão de um arco oceânico com a margem continental (Cardona et al., 2011; Villagómez et al., 2011; Bayona et al., 2012; Spikings et al., 2015), o que teve como consequência o espessamento da crosta continental. Depois da colisão, a reativação da subducção deu início a um magmatismo de arco cujo aspecto marcante é a intrusão de stocks com características geoquímicas e petrográficas de diferenciação a alta pressão, tais como alto $\mathrm{Sr} / \mathrm{Y}$ e presença de epidoto magmático (Capítulo 4). A diferenciação em alta pressão é o resultado de um regime tectônico possivelmente herdado do espessamento crustal, o que permitiu a colocação na crosta inferior, dentro do campo de estabilidade de granada, de melts transferidos da zona de subducção como produto da fusão de sedimentos e crosta oceânica na forma de diápiros (Capítulo 4). 
Adicionalmente, o registro do magmatismo paleogênico marcado nos zircões detríticos depositados em bacias na Cordilheira Oriental e a região dos Llanos da Colômbia, são aparentemente contemporâneo ao da Cordilheira Central. De acordo com Bayona et al., (2012), os zircões detríticos foram associados a um evento magmatismo intraplaca. Isótopos de Hf apresentados no Capítulo 4, obtidos nos zircões dos stocks da Cordilheira Central e dos zircões detríticos das rochas sedimentares do leste Colombiano, sugerem que os plútons da Cordilheira Central podem ser uma fonte potencial dos zircões detríticos. Os estudos sedimentológicos de Bayona et al. (2012), no entanto, não descartam a presença de atividade vulcânica eocênica no leste da Colômbia.

Um regime de flat-slab decorrente da subducção do plateau do Caribe sob a América do Sul estaria atuando durante o Paleógeno (Cardona et al., 2011; Bayona et al., 2012). Esse regime promove compresão generalizada no arco magmático associado a cisalhamento simples destral decorrente da migração para Norte-Nordeste da placa caribenha. A deformacão transpresiva resultante foi capaz de promover a colocação de plútons, como o batólito Santa Marta situado na borda ocidental da Sierra Nevada de Santa Marta. A trama magmática do batólito e suas relações com a tectônica regional foram investigadas através da anisotropia de suscetibilidade e remanência magnética (Capitulo 5).

As propriedades magnéticas do batólito Santa Marta são controladas por grãos de magnetita formados durante a cristalização do magma. A suscetiblidade magnética (SM) média no batólito, da ordem de 4,9 x $10^{-3} \mathrm{SI}(\mathrm{mSI})$, ou seja, típica de granitóides cuja suscetibilidade magnética é controlada por minerais ferromagnéticos (Bouchez, 1997). Contudo, 25\% das amostras (total de 759) apresentaram valores de suscetibildade muito baixos, entre $0,35 \mathrm{mSI}$ e $0.024 \mathrm{mSI}$, indicando que nessas amostras a SM depende do teor dos minerais paramagnéticos, particularmente a biotita e a hornblenda (Rochette, 1987). O exame mais detalhado das propriedades magnéticas dessas amostras revelou, contudo, que a magnetita ainda está presente nas rochas com SM muito baixa. Elas ocorrem como finos cristais que geralmente aparecem no microscópio petrográfico na forma de pequenas inclusões de opacos nos silicatos, ou então como produto local de alteração hidrotermal tardia pós-magmática. $\mathrm{O}$ estudo da orientação preferencial da fração ferromagnética mais fina através da anisotropia de remanência anisterética, mostrou que a anisotropia de suscetibilidade e remanência magnética são coaxiais independentemente da magnitude da SM. Esses resultados indicam, portanto, (i) a ausência de grãos de magnetita muito finos que 
poderiam conduzir a tramas magnéticas inversas e, (ii) a coerência direcional da trama magnética independentemente das populações de grãos com tamanhos diferentes.

A forma da trama magnética e orientação das direções principais de ASM permitiram separar o batólito em dois setores (Capítulo 5). O setor norte contém uma foliação magnética de direção aproximadamente N-S e oblíqua ao alongamento NE-SW do batólito. No setor sul a foliação magnética tende a se paralelizar com as margens da intrusão, sendo que na margem sudeste foi possível mapear uma foliação/acamamento gnáissico também paralelo ao contato da intrusão com a rocha encaixante (Tschanz et al., 1969). Os setores norte e sul são separados por uma estreita faixa cuja foliação magnética possui direção E-W. O conjunto de foliações foi interpretado em termos de um cisalhamento simples destral sin-magmático que definem um sistema de planos conjugados do tipo S (direção de máximo achatamento) / C' (cisalhamento oblíquo extensional). A ASM do batólito foi adquirida quando o magma estava cristalizando sob ação de uma deformação cisalhante regional relacionada ao componente lateral da convergência da Placa do Caribe. Os dados geocronológicos indicam que a fase principal de construção e deformação do batólito ocorreu no intervalo entre 58 e 54 Ma. Pulsos magmáticos mais tardios, entre 52 e 50 Ma, foram associados a reativações do sistema de cisalhamento preferencialmente na direção E-W (eg. borda NE do setor norte do batólito e intrusão do plúton Buritaca).

Reconstruções palinspáticas sugerem que as placas da América do Sul e Caribe migraram lateralmente por pelo menos $1.000 \mathrm{~km}$ entre 84 e $46 \mathrm{Ma}$, e que desde o Cretáceo aproximadamente $1.500 \mathrm{~km}$ da litosfera caribenha foi consumida sob a Colômbia e Venezuela (Kennan \& Pindell, 2009). Parte da deformação continental foi acomodada na sutura de Romeral que separa a Cordilheira Central da Ocidental e, na Sierra Nevada de Santa Marta, sequências oceânicas do prisma acrescionário de rochas permo-triássicas e jurássicas da paleomargem continental. $\mathrm{O}$ alojamento do batólito Santa Marta ocorre junto à sutura e sua trama magmática/magnética registra, portanto, a deformação transpressiva relacionada compressão e migração lateral do placa do Caribe. 


\section{Capítulo 7}

\section{Conclusões}

A integração entre a petrografia, geocronologia $\mathrm{U}-\mathrm{Pb}$ e isótopos de $\mathrm{Hf}$ em zircão, isótopos de $\mathrm{Sr}, \mathrm{Nd}, \mathrm{Pb}$ e $\mathrm{Hf}$ e geoquímica em rocha total de rochas plutônicas e do embasamento metamórfico da Cordilheira Central dos Andes Colombianos permitiu propor um modelo de evolução tectônica que em parte se diferencia dos modelos atualmente vigentes.

As idades $\mathrm{U}-\mathrm{Pb}$ em zircão e isótopos de $\mathrm{Hf}$ em gnaisses e anfibolitos da Unidade Tierradentro, que tradicionalmente foram consideradas como partes da continuação do cinturão Grenvilliano nos Andes Colombianos, mostram que a unidade é permo-triássica. Esses gnaisses a anfibolitos estão limitados pela falha Otú-Pericos, que por sua vez constitui o limite oriental de uma sequência metassedimentar jurássica cuja idade do zircão detrítico mais jovem é de $162 \mathrm{Ma}$. As rochas metasedimentares, consideradas de idade permo-triássica em trabalhos anteriores, pode ser correlacionada à sequências similares da Cordilheira Real do Equador. A composição isotópica de Hf nos zircões detríticos, no entanto, indica que a área fonte dos zircões é distinta das rochas jurássicas atualmente expostas nas cordilheiras Central (Colômbia) e Real (Equador).

A atividade plutônica na Cordilheira Central e no Vale Superior do Magdalena é consistente com a presença de um arco estacionário entre 165 e 129 Ma, o qual é caracterizado por um incremento com o tempo no $\varepsilon_{\mathrm{Nd}(\mathrm{i})}$ e no $\varepsilon_{\mathrm{Hf}(\mathrm{i})}$, o que indica uma evolução da fonte dos magmas. Os dados isotópicos e geocronológicos sugerem que a fusão mantélica incluiria um componente sedimentar e basáltico que, com o tempo, se tornaria mais juvenil com o esgotamento do componente sedimentar radiogênico. Esta diminuição do componente sedimentar na cunha mantélica ocorrria com a crecente obliquidade da subducção, que favoreceria o transporte longitudinal de sedimentos ao longo da trincheira, e o que poderia explicar ainda o término do magmatismo entre 129 e 90 Ma.

No Eoceno o magmatismo registra uma diferenciação a alta pressão para fornecer uma assinatura adakítica às rochas plutônicas, conforme indicado na elevada razão $\mathrm{Sr} / \mathrm{Y}$. O espessamento crustal que permitiu a diferenciação de magmas sob elevada pressão está relacionado à colisão arco-continente que experimentou a margem oeste da América do Sul 
no final do Cretáceo. Os eventos colisionais, relacionados à migração da placa do Caribe, favoreceram a movimentação destral de falhas no arco continental, que por sua vez permitiram a acomodação de magmas tal como documentado na anisotropia de suscetibilidade magnética do batólito Santa Marta. Zircões detríticos eocênicos depositados nas bacias do leste da Colômbia apresentam composições isotópicas de Hf comparáveis aos zircões ígneos do arco paleocênico, sugerindo que o magmatismo eocênico estava em parte exposto à erosão quando da deposição dos sedimentos nas bacias. 


\section{Referências}

Aitcheson, S.J., Harmon, R.S., Moorbath, S., Schneider, A., Soler, P., Soria, E.E., Steele, G., Swainbank, I., Wörner,G., 1995. Pb isotopes define basement domains of the Altiplano, Central Andes. Geology 23: 555-558.

Alonso-Perez, R., Müntener, O., Ulmer, P., 2009. Igneous garnet and amphibole fractionation in the roots of island arcs: experimental constraints on andesitic liquids. Contributions to Mineralogy and Petrology 157: 541-558.

Altenberger, U., and Concha, A., 2005. Late lower to early Middle Jurassic arc magmatism in the northern Ibagué batholith (Colombia). Geología Colombiana 30: 87-97.

Alvarán, M., Naranjo, E., and Zapata, E., 2011. Skarn de cobre en la mina Río Frío, PayandéTolima: Aspectos mineralógicos, metalográficos y microtermométricos. Boletín de Ciencias de la Tierra 29: 7-20.

Álvarez-Galindez, M.J., 2013. Petrologia, geoquímica e metalogenia dos depósitos de ouro El Silencio e La Gran Colômbia, distrito mineiro Segovia-Remédios, Colômbia [M.Sc. thesis]: Brasilia, Universidade de Brasilia, 192 p.

Annen, C., and Sparks, R.S.J., 2002. Effects of repetitive emplacement of basaltic intrusions on thermal evolution and melt generation in the crust. Earth and Planetary Science Letters 203: 937-955.

Annen, C., Blundy, J.D., and Sparks, R.S.J., 2006. The genesis of intermediate and silicic magmas in deep crustal hot zones. Journal of Petrology 47: 505-539.

Arbaret, L., Launeau, P., Diot, H., Sizaret, S., 2013. Magnetic and shape fabrics of magnetite in simple shear flows. Journal of Volcanology and Geothermal Research 249: 25-38.

Archanjo, C.J., Bouchez, J.L., Corsini, M., Vauchez, A., 1994. The Pombal granite pluton: magnetic fabric, emplacement and relationships with the Brasiliano strike-slip setting of NE Brazil (Paraíba State). Journal of Structural Geology 16: 323-335.

Archanjo, C.J., Launeau, P., Hollanda, M.H.B.M., Macedo, J.W.P., Liu, D., 2009. Scattering of magnetic fabrics in the epizonal Cambrian alkaline granite of Meruoca (Ceará State, northeast Brazil). International Journal of Earth Sciences 98: 1793-1807.

Aspden, J.A., McCourt, W.J., Brook, M., 1987. Geometrical control of subduction related magmatism: the Mesozoic and Cenozoic plutonic history of western Colombia. Journal of the Geological Society, London 144: 893-905.

Ayala-Calvo, C., Bayona, G., Ojeda- Marulanda, C., Cardona, A., Valencia, V., Padrón, C. E., Yoris, F., Mesa- Salamanca, J. and García, A., 2009. Stratigraphy and provenance of 
Campanian-Paleogene units in Cesar sub-basin: contributions to the regional tectonic evolution. Geología Colombiana 34: 1-34.

Bachmann, O., Dungan, M.A., Bussy, F., 2005. Insights into shallow magmatic processes in large silicic magma bodies: the trace element record in the Fish Canyon magma body, Colorado. Contributions to Mineralogy and Petrology 149: 338-349.

Barrero, D., 1969. Petrografía del stock de Payandé y metamorfitas asociadas: Boletín Geológico, v. XVII, p. 113-144.

Barrero, D., and Vesga, C., 1976. Mapa geológico del Cuadrángulo K-9 Armero y mitad sur del Cuadrángulo J-9 La Dorada. Ingeominas, scale 1:100.000, 1 sheet.

Barth, A.P., Wooden, J.L., Jacobson, C.E., and Economos, R.C., 2013. Detrital zircon as a proxy for tracking the magmatic arc system: The California arc example. Geology 41: 223-226.

Bayona, G., Cardona, A., Jaramillo, C., Mora, A., Montes, C., Caballero, V., Mahecha, H., Lamus, F., Montenegro, O., Jimenez, G., Mesa, A., and Valencia, V., 2013, Onset of fault reactivation in the Eastern Cordillera of Colombia and proximal Llanos Basin; response to Caribbean-South American convergence in early Palaeogene time: in: Nemčok, M., Mora, A., and Cosgrove, J.W., eds., Thick-skin-dominated orogens: from initial inversion to full accretion: London, Geological Society [London], Special Publication 377: 285314.

Bayona, G., Cardona, A., Jaramillo, C., Mora, A., Montes, C., Valencia, V., Ayala, C., Montenegro, O., Ibañez-Mejia, M., 2012. Early Paleogene magmatism in the northern Andes: Insights on the effects of oceanic plateau - continent convergence. Earth and Planetary Science Letters 331 - 332: 97 - 111.

Bayona, G., Cardona, A., Tellez, G., Garzón A., Pinzón, D., Mendes, J., Ramirez, C., Rueda, M., 2015. Magmatismo Paleoceno-Eoceno Temprano (?) en la Cuenca proximal de los Llanos. XV Congreso Colombiano de Geología, Bucaramanga, Agosto 31-Septiembre 5. $\mathrm{CD}$ con resúmenes.

Bayona, G., García, D., and Mora, G., 1994. La Formación Saldaña: producto de la actividad de estratovolcanes continentales en un dominio de retroarco, in Etayo-Serna, F., ed., Estudios Geológicos del Valle Superior del Magdalena: Bogotá, Universidad Nacional de Colombia, Chapter I, 21 p.

Bayona, G., Jiménez, G., Silva, C., Cardona, A., Montes, C., Roncancio, J., and Cordani, U., 2010. Paleomagnetic data and K-Ar ages from Mesozoic units of the Santa Marta massif: A preliminary interpretation for block rotation and translations. Journal of South American Earth Sciences 29: 817-831.

Bayona, G., Montes, C., Cardona, A., Jaramillo, C., Ojeda, G., Valencia, V., 2011. Intraplate subsidence and basin filling adjacent to an oceanic arc-continental collision; a case from the southern Caribbean-South America plate margin. Basin Research 23: 403-422. 
Bayona, G.; Rapalini, V.; and Constazo-Alvarez, V. 2006. Paleomagnetism in Mesozoic rocks of the northern Andes and its implications in Mesozoic tectonics of northwestern South America. Earth Planets Space 58: 1-18.

Behn, M.B., Keleman, P.B., Hirth, G., Hacker, B.R., and Massone, H.J., 2011. Diapirs as the source of the sediment arc signature in arc lavas. Nature Geoscience 4: 641-646.

Bellos, L.I., Castro, A., Díaz-Alvarado, J., and Toselli, A., 2015. Multi-pulse cotectic evolution and in-situ fractionation of calc-alkaline tonalite-granodiorite rocks, Sierra de Velasco batholith, Famatinian belt, Argentina: Gondwana Research 27: 258-280.

Benn, K., Paterson, S. R., Lund, S. P., Pignotta, G. S. \& Kruse, S., 2001. Magmatic fabrics in batholiths as markers of regional strains and plate kinematics: example of the Cretaceous Mt. Stuart batholith. Physics and Chemistry of the Earth 26: 343-54.

Best, M., 2003, Igneous and Metamorphic Petrology: Blackwell Publishing. 758 p.

Black, L.P.; Kamo, S.L.; Allen, C.M.; Aleinikoff, J.N.; Davis, D.W.; Korsch, R.J.; Foudolis, C. 2003. TEMORA 1: a new zircon standard for Phanerozoic U-Pb geochronology. Chemical Geology 200: 155-170.

Blanco-Quintero, I.F.; García-Casco, A.; Toro, L.M.; Moreno, M.; Ruiz, E.C.; Vinasco, C.J.; Cardona, A.; Lázaro, C.; and Morata, D. 2014. Late Jurassic terrane collision in the northwestern margin of Gondwana (Cajamarca Complex, eastern flank of the Central Cordillera, Colombia). International Geology Review 56: 1852-1872.

Boekhout, F.; Spikings, R.; Sempere, T.; Chiaradia, M.; Ulianov, A.; and Schaltegger, U. 2012. Mesozoic arc magmatism along the southern Peruvian margin during Gondwana breakup and dispersal. Lithos 146-147: 48-64.

Borradaile, G.J., Henry, B., 1997. Tectonic applications of magnetic susceptibility and its anisotropy. Earth Science Reviews 42: 49-93.

Borradaile, G.J., Werner, T., 1994. Magnetic anisotropy of some phyllosilicates. Tectonophysics 235: 223-248.

Boschman, L., van Hinsbergen, D.J.J., Torsvik, T.H., Spakman, W., Pindell, J., 2014. Kinematic reconstruction of the Caribbean region since Early Jurassic. Earth-Science Reviews 138: 102-136.

Bouchez, J.L., 1997. Granite is never isotropic: an introduction to AMS studies in granitic rocks. In: Bouchez, J.L., Hutton, D.H.W., Stephens, W.E., (Eds.), Granite: from segregation of melt to emplacement fabrics. Kluwer Academis Publishers, 95 - 112.

Bouvier, A., Vervoort, J.D., and Patchett, P. J., 2008. The Lu-Hf and Sm-Nd isotopic composition of CHUR: Constraints from unequilibrated chondrites and implications for the bulk composition of terrestrial planets. Earth and Planetary Science Letters 273: 4857. 
Brook, M., 1984, New radiometric age data from S. W. Colombia. Ingeominas-Misión Británica (British Geological Survey), Cali, Colombia. Report 10.

Bustamante, A., Juliani, C., Essene, E.J., Hall, C.M., Hyppolito, T., 2012. Geochemical constraints on blueschist- and amphibolite-facies rocks of the Central Cordillera of Colombia: The Andean Barragán Region. International Geology Review 54: 1013-1030.

Bustamante, C., Archanjo, C., Cardona, A., Valencia, V., Vervoort, J., 2016. Geochronology and geochemistry of late Jurassic to early Cretaceous plutonism in the Central Cordillera and Upper Magdalena valley of the Colombian Andes: a record of long-term arc maturity and oblique subduction. Geological Society of America Bulletin (in press).

Bustamante, C., Cardona, A., Bayona, G., Mora, A., Valencia, V., Gehrels, G., Vervoort, J., 2010. U-Pb LA-ICP-MS Geochronology and tectonic correlation of Middle Jurassic intrusive rocks from the Garzon Massif and the Central Cordillera, Southern Colombia. Boletin de Geologia 32: 93-109.

Caballero, V., Parra, M., Mora, A., López, C., Rojas, L.E., and Quintero, I., 2013, Factors controlling selective abandonment and reactivation in thick-skin orogens: a case study in the Magdalena Valley, Colombia: in: Nemčok, M., Mora, A., and Cosgrove, J.W., eds., Thick-skin-dominated orogens: from initial inversion to full accretion: London, Geological Society [London], Special Publication 377: 343-367.

Calais, E., Symithe, S., de Lépinay, B., Prépetit, C., 2016. Plate Boundary Segmentation in the Northeastern Caribbean from Geodetic Measurements and Neogene Geological Observations. Comptes Rendus Geosciences 348: 42-51.

Cardona, A., Valencia, V., Bayona, G., Duque, J., Ducea, M., Gerhels, G., Jaramillo, C., Montes, C., Ojeda, G., and Ruiz, J., 2011a. Early subduction orogeny in the Northern Andes: Turonian to Eocene magmatic and provenance record in the Santa Marta massif and Rancheria Basin, Northern Colombia. Terra Nova 23: 26-34.

Cardona, A., Valencia, V., Weber, M., Duque, J., Montes, C., Reiners, P., Domanik, K., Nicolescu, S., Villagomez, D., 2011b. Transient Cenzoic tectonic stages in the southern margin of the Caribbean plate: U-Th/He thermochronological constraints from Eocene plutonic rocks in the Santa Marta Massif and Serranía de Jarara, northern Colombia. Geologica Acta 9: 445 - 466.

Cardona, A., Weber, M., Valencia, V., Bustamante, C., Montes, C., Cordani, U., Muñoz, C.M., 2014. Geochronology and geochemistry of the Parashi granitoid, NE Colombia: Tectonic implications of short-lived Early Eocene plutonism along the SE Caribbean margin. Journal of South American Earth Sciences 50: 75-92.

Cardona, A.; Valencia, V.; Garzón, A.; Montes, C.; Ojeda, C.; Ruiz, J.; and Weber, M. 2010. Permian to Triasic I to S-type magmatic switch in the northeast Sierra Nevada de Santa Marta and adjacent regions, Colombian Caribbean: tectonic setting and implications with Pangea paleogeography. Journal of South American Earth Sciences 29: 772-783. 
Cardona-Molina, A.; Cordani, U.G.; and Macdonald, W. 2006. Tectonic correlations of preMesozoic crust from the northern termination of the Colombian Andes, Caribbean region. Journal of South American Earth Sciences 21: 337-354.

Castillo, P.R., 2012. Adakite petrogenesis. Lithos 134-135: 304-316.

Castro, A., 2014. The off-crust generation of granite batholiths. Geosciences Frontiers 5: 6375.

Castro, A., Gerya, T., García-Casco, A., Fernández, C., Díaz-Alvarado, J., Moreno-Ventas, I., and Löw, I., 2010. Melting relations of MORB-Sediment mélanges in underplated mantle wedge plumes; implications for the origin of Cordilleran-type batholiths. Journal of Petrology 51: 1267-1295.

Castro, A., Vogt, K., and Gerya, T., 2013. Generation of new continental crust by sublithospheric silicic-magma relamination in arcs: A test of Taylor's andesite model. Gondwana Research 23: 1554-1566.

Cawood, P.A., Hawkesworth, C.J., and Dhuime, B., 2012. Detrital zircon record and tectonic setting. Geology 40: 875-878.

Cediel, F., and C. Cáceres, 2000. Geological Map of Colombia, Third Edition: Geotec Ltd., Bogotá, digital format with legend and tectonostratigraphic chart.

Cediel, F., R. P. Shaw, and C. Cáceres, 2003. Tectonic assembly of the Northern Andean Block, in C. Bartolini, R. T. Buffler, and J. Blickwede, eds., The Circum-Gulf of Mexico and the Caribbean: Hydrocarbon habitats, basin formation, and plate tectonics. AAPG Memoir 79: 815-848.

Chang, Z., Vervoort, J.D. McClelland, W.C., and Knaack C., 2006. U-Pb dating of zircon by LA-ICP-MS. Geochemistry, Geophysics, Geosystems 7: 1-14.

Chapman, J.B., Ducea, M.N., DeCelles, P.G., Profeta, L., 2015. Tracking changes in crustal thickness during orogenic evolution with $\mathrm{Sr} / \mathrm{Y}$; an example from the North American Cordillera. Geology 43: 919-922.

Chiaradia, M., 2009. Adakite-like magmas from fractional crystallization and meltingassimilation of mafic lower crust (Eocene Macuchi arc, Western Cordillera, Ecuador). Chemical Geology 265: $468-487$.

Chiaradia, M., 2015. Crustal thickness control on Sr/Y signatures of recent arc magmas: an Earth scale perspective. Science 5: 8115 .

Chiaradia, M., Vallance, J., Fontboté, Ll., Stein, H., Schaltegger, U., Coder, J., Richards, J., Villeneuve, M., and Gendall, I., 2009. U-Pb, Re-Os and 40Ar/39Ar geochronologyof the Nambija Au-skarn and Pangui porphyry $\mathrm{Cu}$ deposits, Ecuador: implications for the Jurassic metallogenic belt of the Northern Andes. Mineralium Deposita 44: 371-387. 
Cochrane, R., Spikings, R., Gerdes, A., Ulianov, A., Mora, A., Villagómez, D., Putlitz, B., and Chiaradia, M. 2014a. Permo-Triassic anatexis: continental rifting and the disassembly of western Pangaea. Lithos 190-191: 383-402.

Cochrane, R., Spikings, R., Gerdes, A., Winkler, W., Ulianov, A., Mora, A., and Chiaradia, M. 2014b. Distinguishing between in-situ and accretionary growth of continents along active margins. Lithos 202-203: 382-394.

Coldwell, B., Clemens, J., Petford, N., 2011. Deep crustal melting in the Peruvian Andes: Felsic magma generation during delamination and uplift. Lithos 125: 272-286.

Coleman, D., Gray, W., Glazner, A.F., 2004. Rethinking the emplacement and evolution of zoned plutons: Geochronological evidence for incremental assembly of the Tuolumne intrusive suite, California. Geology 32: 433-436.

Conrad, C. P., Wi, B., Smith, E. I., Bianco, T. A., Tibbetts, A., 2010. Shear-driven upwelling induced by lateral viscosity variations and asthenospheric shear: A mechanism for intraplate volcanism. Physics of the Earth and Planetary Interiors 178: 162-175

Conrad, C.P., Bianco, T. A., Smith, E. I., Wessel, P., 2011. Patterns of intraplate volcanism controlled by asthenospheric shear. Nature Geoscience 4: 317-321.

Cordani, U.; Cardona, A.; Jimenez, D.M.; Liu, D.; and Nutman, A. 2005. Geochronology of Proterozoic basement inliers in the Colombian Andes: tectonic history of remnants of a fragmented Grenville belt. Geological Society of London: Special Publication 246: 329346.

Cox, K.G., Bell, J.D., and Pankhurst, R.J., 1979. The Interpretation of Igneous Rocks: George Allen \& Unwin, 450 p.

Cuadros, F.A.; Botelho, N.F.; Ordóñez-Carmona, O.; and Matteini, M. 2014. Mesoproterozoic crust in the San Lucas Range (Colombia): An insight into the crustal evolution of the northern Andes. Precambrian Research 245: 186-206.

Defant, M.J., Drummond, M.S., 1990. Derivation of some modern arc magmas by melting of young subducted lithosphere. Nature 347: 662-665.

DeGraaff-Surpless, K., Wooden, J.L., and McWilliams, M.O., 2002. Detrital zircon provenance analysis of the Great Valley Group, California, Evolution of an arc-forearc system. Geological Society of America Bulletin 114: 1564-1580.

DePaolo, D.J., 1988. Age dependence of the composition of continental crust: evidence from $\mathrm{Nd}$ isotopic variations in granitic rocks. Earth and Planetary Science Letters 90 (3): 263 271.

Dickin, A.P., 2005. Radiogenic isotope geology. Cambridge University Press, 2 ed. 509 p.

Dickinson, W.R.; and Lawton, T.F. 2001. Carboniferous to Cretaceous assembly and fragmentation of México. Geological Society of America Bulletin 113: 1142-1160. 
Ducea, M., 2001. The California arc: thick granitic batholiths, eclogitic residues, lithosphericscale thrusting, and magmatic flare-ups. Geological Society of America Today 11: 4-10

DuFrane, S.A., Vervoort, J.D., Hart, G.L., 2007. Uncertainty of Hf isotope analysis in zircon using LA-MC-ICPMS techniques: full disclosure: Geochimica et Cosmochimica Acta, V.M. Goldschmidt Conference, 17th, Cologne, Abstracts, v. 71, p. A241.

Duncan, R.A., Hargraves, R.B., 1984. Plate tectonic evolution of the Caribbean region in the mantle reference frame. in Bonini, W. et al., eds., The Caribbean-South American plate boundary and regional tectonics. Geological Society of America Memoir 162, p. 81-93.

Duque, F., 2009. Geocronología (U-Pb y Ar-Ar) y geoquímica de los intrusivos paleógenos de la Sierra Nevada de Santa Marta y sus relaciones con la tectónica del Caribe y el arco magmático circun-Caribeño. Tesis de Maestria en Ciencias de la Tierra, Universidad Nacional Autónoma de Mexico. 176 pp.

Echeverri, S., Cardona, A., Pardo, A., Monsalve, G., Valencia, V.A., Borrero, C., Rosero, S., López, S., 2015. Regional provenance from southwestern Colombia fore-arc and intra-arc basins: implications for Middle to Late Miocene orogeny in the Northern Andes. Terra Nova 27: 356-363.

Eggins, S.M., Kinsley, L.P.J., and Shelly, J.M.G., 1998. Deposition and elemental fractionation processes during atmospheric pressure laser ablation sampling for analysis by ICP-MS. Applied Surface Science 127: 278-286.

Escalona, A., Mann, P., 2011. Tectonics, basin subsidence mechanisms and paleogeography of the Caribbean-South American plate boundary zone. Marine and Petroleum Geology 28: 8-39.

Evans, B.W., Vance, J.A., 1987. Epidote phenocrysts in dacitic dikes, Boulder County, Colorado. Contributions to Mineralogy and Petrology 96: 178-185.

Faure, G., Mensing, T.M., 2005. Isotopes: Principles and applications. John Wiley \& Sons, Inc. 3 ed. 897 p.

Fawcett, T.C., Burmester, R.F., Housen, B.A., Iriondo, A., 2003. Tectonic implications of magnetic fabrics and remanence in the Cooper Mountain pluton, North Cascade Mountains, Washington. Canadian Journal of Earth Sciences 40: 1335-1356.

Feininger, T., Botero, G., 1982. The Antioquian btholith. Publicación Geológica Espacial INGEOMINAS 12, $50 \mathrm{pp}$.

Ferré, E.C., Michelsen, K.J., Ernest, W.G., Boyd, J.D., Canon-Tapia, E., 2012. Vertical zonation of the Barcroft granodiorite, White Mountains, California: Implications for magmatic processes. American Mineralogist 97: 1049-1059.

Galer, S.J.G., and Abouchami, W., 1998. Practical application of lead triple spiking for correction of instrumental mass discrimination: Mineralogical Magazine 62A: 491-492. 
Gehrels, G., Valencia, V.A., Ruiz, J., 2008. Enhanced precision, accuracy, efficiency, and spatial resolution of $\mathrm{U}-\mathrm{Pb}$ ages by laser ablation-multicollector-inductively coupled plasma-mass spectrometry. Geochemistry, Geophysics and Geosystems 9 (3).

Gendall, I.R., Quevedo, L.A., Sillitoe, R.H., Spencer, R.M., Puente, C.O., Leon, J.P., and Povedo, R.R., 2000. Discovery of a Jurassic porphyry copper belt, Pangui área, southern Ecuador: SEG Newsletter 43: 8-15.

Gerya, T.V., Yuen, D.A., 2003. Characteristicsbased marker-in-cell method with conservative finitedifferences schemes for modeling geological flows with strongly variable transport properties. Phys. Earth Planet. In. 140: 293-318.

Glazner, A. F., 1991. Plutonism, oblique subduction, and continental growth: An example from the Mesozoic of California. Geology 19: 784-786.

Gómez-Tapias, J.; Montes-Ramírez, N.E.; Nivia-Guevara, A.; and Diedrix, H., 2015. Mapa Geológico de Colombia Escala 1:1.000.000 Servicio Geológico Colombiano.

González, H., Londoño, A.C., 2002. Catálogo de las unidades Litoestratigráficas de Colombia: Granodiorita de Manizales. Ingeominas, Bogotá 19 p.

Goodge, J.W., Vervoort, J.D., 2006. Origin of Mesoproterozoic A-type granites in Laurentia: Hf isotope evidence. Earth and Planetary Science Letters 243: 711-731.

Gorczyk, W., Willner, A.P., Gerya, T.V., Connolly, J.A.D., and Burg, J.P., 2007. Physical controls of magmatic productivity at Pacific-type convergent margins: Numerical modeling. Physics of the Earth and Planetary Interiors 163: 209-232.

Grocott, J., Taylor, G.K., 2002. Magmatic arc fault systems, deformation partitioning and emplacement of granitic complexes in the Coastal Cordillera, north Chilean Andes $\left(25^{\circ} 30^{\prime}\right.$ S to $\left.27^{\circ} 00 ' S\right)$. Journal of the Geological Society, London 159: 425-442.

Gurnis, M., Hall, C., Lavier, L., Evolving force balance during incipient subduction. Geochememistry. Geophysics. Geosystems, 5, Q07001.

Hacker, B.R., Kelemen, P.B., and Behn, M.D., 2011. Differentiation of the continental crust by relamination: Earth and Planetary Science Letters 307: 501-516.

Harris, N.W., Pearce, J.A., and Tindle, A.G., 1986. Geochemical characteristics of collisionzone magmatism. Geological Society [London], Special Publication 19: 67-81.

Henry, B., Légeois, J.P., Nouar, O., Derder, M.E.M., Bayou, B., Bruguier, O., Oubadi, A., Belhai, D., Amenna, M., Hemmi, A., Ayache, M., 2009. Repeated granitoid intrusions during the Neoproterozoic along the western boundary of the Saharan metacraton, Eastern Hoggar, Tuared shield, Algeria: An AMS and U-Pb zircon age study. Tectonophysics 474: 417-434. 
Hervé, F., Pankhurst, R.J., Fanning, C.M., Calderón, M., and Yaxley, G.M., 2007. The South Patagonian batholith: 150 my of granite magmatism on a plate margin. Lithos 97: 373394.

Hoernle, K., Abt, D.L., Fischer, K.M., Nichols, H., Hauff, F., Abers, G.A., van den Bogaard, P., Heydolph, K., Alvarado, G., Protti, M., and Strauch, W., 2008. Arc-parallel flow in the mantle wedge beneath Costa Rica and Nicaragua. Nature Letters 451: 1094-1098.

Horton, B.K., Saylor, J.E., Nie, J., Mora, A., Parra, M., Reyes-Harker, A., and Stocki, D.F., 2010. Linking sedimentation in the northern Andes to basement configuration, Mesozoic extension, and Cenozoic shortening: evidence from detrital zircon U-Pb ages, Eastern Cordillera, Colombia. Geological Society of America Bulletin 122: 1423-1442.

Howell, D.G. 1995. Principles of terrane analysis: new applications for global tectonics, 2nd edn. Chapman \& Hall, London.

Howell, D.G.; Schermer, E.R.; Jones, D.L.; Ben-Avraham, Z.; and Scheibner, E. 1983. Tectonostratigraphic terrane map of the circum-Pacific region. United States Department of the Interior Geological Survey. Open file report 83-716, 23 pp.

Hrouda, F., 1982. Magnetic anisotropy of rocks and its application in geology and geophysics. Geophysical Surveys: 37-82.

Ibañez-Mejía, M., Tassinari, C.C.G., and Jaramillo-Mejía, J.M., 2007, U-Pb ages of the Antioquian Batholith - Geochronological constraints of late Cretaceous magmatism in the Central Andes of Colombia: Congreso Colombiano de Geología, 11th, Bucaramanga, Abstracts, p. 11.

Ibáñez-Mejía, M.; Ruiz, J.; Valencia, V.; Cardona, A.; Gehrels, G.; and Mora, A. 2011. The Putumayo Orogen of Amazonia and its implications for Rodinia reconstructions: New U$\mathrm{Pb}$ geochronological insights into the Proterozoic tectonic evolution of northwestern South America. Precambrian Research 191: 58-77.

Ishihara, S., 1977. The magnetite-series and ilmenite-series granitic rocks. Minning Geology 27: 293-305.

Jackson, M., 1991. Anisotropy of magnetic remanence: a brief review of mineralogical sources, physical origins and geological applications, and comparison with susceptibility anisotropy. Pageoph., 136: 1-28.

Jackson, M., Gruber, W., Marvin, J., Benerjee, S.K., 1988. Partial anhysteretic remanence and its anisotropy: Applications and grain-size dependence. Geophysical Research Letters 15: 440-443.

Jaillard, E., Hérail, G., Monfret, T., Diaz-Martinez, E., Baby, P., Lavenu, A, Dumon, J. F., 2000. Tectonic evolution of the Andes of Ecuador, Peru, Bolivia and northernmost Chile. In: Cordani, U. G., Milani, E. J., Thomaz-Filho, A, Campos, D. A, Tectonic evolution of South America. Rio de Janeiro 31st International Geological Congress. 481-559. 
Jaillard, E., Soler, P., Carlier, G., and Mourier, T., 1990. Geodynamic evolution of the northern and central Andes during early to middle Mesozoic times: a Tethyan model: Journal of the Geological Society [London] 147: 1009-1022.

Jarrard, R.D., 1986. Relations among subduction parameters: Reviews of Geophysics, v. 24, no. 2 , p. $217-284$.

Johnson, D.M., Hooper, P.R., and Conrey, R.M., 1999. XRF analysis of rocks and minerals for major and race elements on a single low dilution Li-tetraborate fused bead: JCPDSInternational Centre for Diffraction Data: 843-867.

Just, J., Kontny, A., Wall, H., Hirt, A.M., Martin-Hernandez, F., 2004. Development of magmatic fabrics during hydrothermal alteration in the Soultz-sous-Forêts granite from the EPS-1 borehole, Upper Rhine Graben. in: Magnetic Fabric: Methods and Applications, F. Martin-Hernandez, C.M. Luneburg, C. Aubourg and M. Jackson (eds). Geological Society, London, Special Publications 238: 509-526.

Kay, R.W., Kay, S.M., 1993. Delamination and delamination magmatism. Tectonophysics 219: 177-189.

Kay, S., Mpodozis, C., 2001. Central Andean Ore Deposits Linked to Evolving Shallow Subduction Systems and Thickening Crust. GSA Today 3: 4-9.

Kemp, A.I.S., Hawkesworth, C.J., Collins, W.J., Gray, C.M., Blevin, P.L., and EIMF, 2009. Isotopic evidence for rapid continental growth in an extensional accretionary orogen: The Tasmanides, eastern Australia. Earth and Planetary Science Letters 284: 455-466.

Kennan, L., Pindell, J.L., 2009. Dextral shear, terrane accretion and basin formation in the Northern Andes. Best explained by interaction with a Pacific-derived Caribbean Plate? From: James, K.H., Lorente, M.A., Pindell, J.L. (eds) The Origin and Evolution of the Caribbean Plate. Geological Society, London, Special Publications 328: 487-531.

Kerr, A.C., 2014. Oceanic Plateaus. Treatise on Geochemistry, 2nd Edition, Elsevier, p. 631667.

Kerr, A.C., Marriner, G.F., Tarney, J., Nivia, A., Saunders, A.D., Thirlwall, M.F., Sinton, C.W., 1997. Cretaceous basaltic terranes in Western Colombia: elemental, chronological and $\mathrm{Sr}-\mathrm{Nd}$ Isotopic Constraints on petrogenesis. Journal of Petrology 38: 677-702.

Kerr, A.C., Tarney, J., 2005. Tectonic evolution of the Caribbean and northwestern South America: the case for accretion on two Late Cretaceous oceanic plateaus. Geology, 23: 269-272.

Kinny, P.D., Maas, R., 2003. Lu-Hf and Sm-Nd isotope systems in zircon. In: Hanchar, J.M., Hpskin, P.W.O., (Eds.), Zircon. Reviews in Mineralogy and Geochemistry 53: 327-339.

Kosler, J., and Sylvester, P., 2003. Present trends and the future of zircon in geochronology: laser ablation ICPMS. Reviews in Mineralogy and Geochemestry 53: 243-275. 
Kroonenberg, S. 1982. A grenvillian granulite belt in the Colombian Andes and its relations to the Guiana Shield. Geologie en Mijnbouw 61: 325-333.

Leal-Mejía, H. 2011, Phanerozoic gold metallogeny in the Colombian Andes: A tectonomagmatic approach. [PhD Thesis]: Barcelona, Universitat de Barcelona, $1000 \mathrm{p}$.

Leal-Mejía, H., Shaw, R.P., Padilla, R., Valencia, V., 2010. Magmatism vs. Mineralization in the Segovia-Remedios and Central Antioquia Au Districts, Colombia [poster]: SEG2010 Conference.

Lee, C.-T.A., Morton, D.M., Kistler, R.W., and Baird, A.K., 2007. Petrology and tectonics of Phanerozoic continent formation: From island arcs to accretion and continental arc magmatism. Earth and Planetary Science Letters 263: 370-387.

Li, S., Wilde, S.A., Wang, T., Xiao, W., and Guo, Q., 2016, Latest Early Permian granitic magmatism in southern Inner Mongolia, China: Implications for the tectonic evolution of the southeastern Central Asian Orogenic Belt. Gondwana Research 29: 168-180.

Litherland, M. 1994. The metamorphic belts of Ecuador. British Geological Survey. Overseas Memoir 11, 147 p.

Ludwig, K.R., 2000. SQUID 1.00. A user manual. Berkeley Geochronology Center Spec. Publ., vol. 2. Berkeley, CA, 17p.

Ludwig, K.R., 2003. Isoplot 3.00: a geochronological toolkit for Microsoft Excel ${ }^{\circledR}$ (revised version). Berkeley Geochronological Center, Special Publ. 4, Berkeley, California, 70pp.

Luzieux, L.D.A., Heller, F., Spikings, R., Vallejo, C.F., Winkler, W., 2006. Origin and Cretaceous tectonic history of the coastal Ecuadorian forearc between $1^{\circ} \mathrm{S}-4^{\circ} \mathrm{S}$ : paleomagnetic, radiometric and fossil evidence. Earth and Planetary Science Letters 249: 400-414.

Macpherson, C.G., Dreher, S.T., Thirlwall, M.F., 2006. Adakites without slab melting: high pressure differentiation of island arc magma, Mindanao, the Philippines. Earth and Planetary Science Letters 243: 581-593.

Malatesta, C., Gerya, T., Crispini, L., Federico, L., and Capponi, G., 2013. Oblique subduction modeling indicates along-trench tectonic transport of sediments: Nature Communications 4: 2456.

Maloney, K.T., Clarke, G.L., Klepeis, K.A., and Quevedo, L., 2013. The Late Jurassic to present evolution of the Andean margin: Drivers and the geological record. Tectonics 32: $1049-1065$.

Mantilla-Figueroa, L.C., Bissig, T., Valencia, V., and Hart, C., 2013. The magmatic history of the Vetas-California mining district, Santander Massif, Eastern Cordillera, Colombia. Journal of South American Earth Sciences 45: 235-249. 
Marquinez, G.; and Núñez, A. 1998. Catálogo de las unidades litoestratigráficas de Colombia: Neises y anfibolitas de Tierradentro. Ingeominas: 22 p. Bogotá.

Martens, U.; Restrepo, J.J.; Ordóñez-Carmona, O.; and Correa-Martinez, A.M.. 2014. The Tahamí and Anacona terranes of the Colombian Andes: Missing links between the South American and Mexican Gondwana margins. The Journal of Geology 122: 507-530.

Martin, H., Smithies, R.H., Rapp, R., Moyen, J.F., Champion, D., 2005. An overview of adakite, tonalite-trondhjemite-granodiorite (TTG), and sanukitoid: relationships and some implications for crustal evolution. Lithos 79: 1-24.

Martín-Hérnandez, F. and Hirt, A.M., 2003. The anisotropy of magnetic susceptibility in biotite, muscovite and chlorite single crystals. Tectonophysics 367: 13-28.

Massone, H.J.; and Toulkeridis, T. 2010. Widespread relics of high-pressure metamorphism confirm major terrane accretion in Ecuador: a new example from the Northern Andes. International Geology Review 54: 67-80.

Matsumoto, Y., Enami, M., Tsuboi,M., Hong,M., 2014. Magmatic zoisite and epidote in tonalite of the Ryoke belt, central Japan. European Journal of Mineralogy 26: 279-291.

Matzel, J.E.P., Bowring, S.A., Miller, R., 2006. Time scales of pluton construction at different crustal levels: Examples from the Mount Stuart and Tenpeak intrusions, North Cascades, Washington. Geological Society of American Bulletin 118: 1412-1430.

Maya, M.; and González, H. 1995. Unidades litodémicas en la Cordillera Central de Colombia. Boletín Geología 35: 43-57.

McCabe, C., Jackson, M., Ellwood, B.B., 1985. Magnetic anisotropy in the Trenton limestone: results of a new technique, anisotropy of anhysteretic susceptibility. Geophysical Research Letters 12: 333-336.

McDougall, I., and Harrison, T.M., 1999. Geochronology and thermochronology by the ${ }^{40} \mathrm{Ar} /{ }^{39} \mathrm{Ar}$ method: Oxford University Press, $2^{\text {nd }}$ ed. $261 \mathrm{p}$.

Montes, C., Bayona, G., Cardona, A., Busch, D.M., Silva, C.A., Morón, S.A., Hoyos, N., Ramirez, D.A., Jaramillo, C., Valencia, V., 2012. Arc-Continent Collision and Orocline Formation: Closing of the Central America Seaway. Journal of Geophysical Research 117 B04125: 25 pp.

Montes, C., Cardona, A., Jaramillo, C., Pardo, A., Silva, J.C., Valencia, V., Ayala, C., PérezAngel, L.C., Rodríguez-Parra, L.A., Ramírez, V., Niño, H., 2015. Middle Miocene closure of the Central American Seaway. Science 348: 226-229.

Montes, C., Guzmán, G., Bayona, G., Cardona, A., Valencia, V., 2010. Clockwise rotation of the Santa Marta massif and simultaneous Paleogene to Neogene deformation of the PlatoSan Jorge and Cesar-Ranchería basins. Journal of South American Earth Sciences 29: 832-848. 
Mora, A., Gaona, T., Kley, J., Montoya, D., Parra, M., Quiroz, L.I., Reyes, G., and Strecker, M.R., 2009. The role of inherited extensional fault segmentation and linkage in contractional orogenesis: A reconstruction of Lower Cretaceous inverted rift basin in the Eastern Cordillera of Colombia. Basin Research 21: 111-137

Moyen, J.F., 2009. High Sr/Y and La/Yb ratios: The meaning of the "adakitic signature". Lithos 112: 556-574.

Moyen, J.F., Nédélec, A., Martin, H., Jayananda, M., 2003. Syntectonic granite emplacemtn at different structural levels: the Closepet granite, South India. Journal of Structural Geology 25: 611-631.

Münker, C., Weyer, S., Scherer, E., Mezger, K., 2001, Separation of high field strength elements $(\mathrm{Nb}, \mathrm{Ta}, \mathrm{Zr}, \mathrm{Hf})$ and $\mathrm{Lu}$ from rock samples for MC-ICPMS measurements: Geochemistry, Geophysics, Geosystems 2 (12): 1064.

Müntener, O., Kelemen, P.B., Grove, T.L., 2001. The role of $\mathrm{H}_{2} \mathrm{O}$ during crystallization of primitive arc magmas under uppermost mantle conditions and genesis of igneous pyroxenites: an experimental study. Contributins to Mineralogy and Petrology 141: 643658.

Muxworthy, A.R., McClelland, E., 2000. Review of the low-temperature magnetic properties of magnetite from a rock magnetic perspective. Geophysical Journal International 140: $101-114$

Nakamura, N., 1974. Determination of REE, Ba, Fe, Mg, $\mathrm{Na}$ and $\mathrm{K}$ in carbonaceous and ordinary chondrites. Geochimica et Cosmochimica Acta 38: 757-775.

Nédélec, A., Trindade, R., Peschler, A., Archanjo, C.J., Macouin, M., Poitrasson, F., Bouchez, J.L., 2015. Hydrothermally-induced changes in mineralogy and magnetic properties of oxidized A-type granites. Lithos 212: 145-157.

Neves, S.P., Vauchez, A., Archanjo, C.J., 1996. Shear zone-controlled magma emplacement or magma-assisted nucleation of shear zones? Insights from northeast Brazil. Tectonophysics 262: 349-364.

Nie, J., Horton, B.K., Mora, A., Saylor, J.E., Housh, T.B., Rubiano, J., and Naranjo, J., 2010, Tracking exhumation of Andean ranges bounding the Middle Magdalena Valley Basin, Colombia. Geological Society of America Bulletin 38: 451-454.

Nivia, A., 1996. The Bolívar mafic-ultramafic complex, SW Colombia: the base of an oceanic plateau. Journal of South American Earth Sciences 9: 59-68.

Noble, S.R., Aspeden, J.A., Jemelita, R., 1997, Northern Andean crustal evolution: New U-Pb geochronological constraints from Ecuador. Geological Society of America Bulletin 109: 789-798. 
Núñez, A. 2001. Mapa Geológico del Departamento del Tolima escala 1: 250.000. Memoria explicativa. Ingeominas: 101 p. Bogotá.

Ordoñez, O., Pimentel, M., 2001a. Consideraciones geocronológicas e isotópicas del Batolito Antioqueño. Revista de la Acedemia de Ciencias Exactas, Fisicas y Naturales 25: 27 - 35.

Ordoñez, O., Pimentel, M.M., Armstrong, R.A., Gioia, S.M.C.L., Junges, S., 2001b, U-Pb SHRIMP and Rb-Sr ages of the Sonsón Batholith: III South-American Symposium on Isotope Geology (SASIG 2001, Pucon, Chile), Extended Abstracts.

Ordóñez-Carmona, O., Pimentel, M., and Laux, J.H., 2007, Edades U-Pb del Batolito Antioqueño. Boletín de Ciencias de la Tierra 22: 129-130.

Ordóñez-Carmona, O.; Pimentel, M.M.; 2002. Rb-Sr and Sm-Nd isotopic study of the Puquí complex: Colombian Andes. Journal of South American Earth Sciences 15: 173-182.

Ordóñez-Carmona, O.; Restrepo, J.J.; and Pimentel, M.M. 2006. Geochronological and isotopical review of pre-Devonian crustal basement of the Colombian Andes. Journal of South American Earth Sciences 21: 372-382.

Ozdemir, O., Dunlop, D.J., Moskowitz, B.M. 1993. The effect of oxidation on the Verwey transition in magnetite. Geophysical Research Letters 20: 1671-1674.

Pankhurst, R.J., Weaver, S.D., Hervé, F., and Larrondo, P., 1999, Mesozoic-Cenozoic evolution of the North Patagonian Batholith in Aysen, southern Chile: Journal of the Geological Society [London] 156: 673-694.

Parada, M.A., Roperch, P., Guiresse, C., Ramirez, E., 2005. Magnetic fabrics and compositional evidence for the construction of the Caleu pluton by multiple injections, Coastal Range of Central Chile. Tectonophysics 399: 399-420.

Parra, M., Mora, A., Lopez, C., Rojas, L.E., Horton, B.K., 2012. Detecting earliest shortening and deformation advance in thrust-belt hinterlands: example from the Colombian Andes. Geology 40: 175-178.

Peacock, S.M., Rushmer, T., Thompson, A.B., 1994. Partial melting of subducting oceaniccrust. Earth and Planetary Science Letters 121 (1-2): 227-244.

Peccerillo, A., and Taylor, T.S., 1976. Geochemistry of Eocene calc-alkaline volcanic rocks from Kastamonu area, Northern Turkey. Contributions to Mineralogy and Petrology 58: 63-81.

Pereira, M.F., Castro, A., and Fernández, C., 2015, The inception of a Paleotethyan magmatic arc in Iberia. Geosciences Frontiers 6: 297-306.

Pindell, J. and Kennan, L., 2009. Tectonic evolution of the Gulf of Mexico, Caribbean and northern South America in the mantle reference frame: an update. In: The Origin and Evolution of the Caribbean Plate (K.H. James, M.A. Lorente and J. Pindell, eds.), Geological Society of London, Special Publication 328: 1-56. 
Pindell, J., Kennan, L., Maresch, W.V., Stanek, K.P., Draper, G., and Higgs, R., 2005. Plate kinematic and crustal dynamics of circum-Caribbean arc-Continent interactions: tectonics controls on basin development in the Proto-Caribbean margins. In: Avé Lallemant, H. G., Sisson, V.B. (Eds.), Caribbean-South American Plate Interactions. Geological Society of America. Special Paper 394: 7-52.

Plazas, J., Zuluaga, C., López, J., 2013. Condiciones de emplazamiento, mineralogía y geoquímica de la tonalita-granodiorita de Manizales, Caldas. XIV Congreso Colombiano de Geología, Bogotá. 354 pp.

Poli, S., Schmidt, M.W., 2002. Petrology of subducted slabs. Annual Review of Earth and Planetary Science Letters 30: 207-235.

Profeta, L., Ducea,M.N., Chapman, J.B., Paterson, S.R., Henríquez-Gonzáles, S.M., Kirsch, M., Petrescu, L., DeCelles, P.G., 2015. Quantifying crustal thickness over time in magmatic arcs. Scientific Reports 5: 17786.

Ramos, V. 2009 Anatomy and global context of the Andes: Main geologic features and the Andean orogenic cycle. in Kay, S.M., Ramos, V.A., Dickinson, W.D., eds., Backbone of the Americas: Shallow Subduction, Plateau Uplift, and Ridge and Terrane Collision. Geological Society of America Memoir 204: 31-66.

Ramos, V., Aleman, A, 2000. Tectonic evolution of the Andes. In: Cordani, U.G., Milani, E.J., Thomaz-Filho, A, Campos, D.A, (Eds.), Tectonic evolution of South America. Rio de Janeiro 31st International Geological Congress. 635-685.

Raposo, M.I.B., Gastal, M.C., 2009. Emplacement mechanism of the main granite pluton of the Lavras do Sul intrusive complex, South Brazil, determined by magnetic anisotropies. Tectonophysics 466: 18-31.

Restrepo, J.J., Ordóñez-Carmona, O., Armstrong, R., and Pimentel, M.M., 2011. Triassic metamorphism in the northern part of the Tahamí Terrane of the central cordillera of Colombia. Journal of South American Earth Sciences 32: 497-507.

Restrepo, J.J., Toussaint, J.F., 1988. Terranes and continental accretion in the Colombian Andes. Episodes 11: 189-193.

Restrepo-Moreno, S., Foster, D., and Kamenov, G., 2007, Formation age and magma sources for the Antioqueño Batholith derived from LA-ICP-MS U-Pb and $\mathrm{Hf}$ isotope analysis of zircon grains: Geological Society of America Abstracts with programs 39: 493 pp.

Restrepo-Moreno, S.A., Foster, D., Kamenov, G.D., 2009. Crystallization age and magma sources of the Antioqueño and Ovejas batholiths, Central Cordillera, Colombia: evidence from combined LA-ICP-MS U-Pb dating and Hf-isotope analysis of zircon grains and whole-rock geochemistry. Geological Society of America, Portland Annual Meeting, paper No. 79-3. 
Restrepo-Pace, P.A., Ruiz, J., Gehrels, G., Cosca, M., 1997. Geochronology and Nd isotopic data of Grenville-age rocks in the Colombian Andes: new constraints for Late Proterozoic-Early Paleozoic paleocontinental reconstructions of the Americas. Earth and Planetary Science Letters 150: 427-441.

Richards, J.R., Kerrich, R., 2007. Special paper: Adakite-like rocks: their diverse origins and questionable role in metallogenesis. Economic Geology 102 (4): 537-576.

Riel, N.; Guillot, S.; Jaillard, E.; Martelat, J.E.; Paquette, J.L.; Schwartz, S.; Goncalves, P.; Declaux, G.; Thebaud, N.; Lanari, P.; Janots, E.; and Yuquilema, J. 2013. Metamorphic and geochronogical study of the Triassic El Oro metamorphic complex, Ecuador: Implications for high-temperature metamorphism in a forearc zone. Lithos 156-159: 4168.

Rochette, P., 1987. Magnetic susceptibility of the rock matrix related to magnetic fabric studies. Journal of Structural Geology 9(8): 1015-1020.

Rollinson, H.R., 1993. Using Geochemical Data: Evaluation, Presentation, Interpretation. Prentice Hall, Singapore, 352 p.

Rooney, T.O., Franceschi, P., Hall, C.M., 2011. Water-saturated magmas in the Panama Canal region: a precursor to adakite-like magma generation? Geochemistry, Geophysics, Geosystems 16: 4178-4208.

Rooney, T.O., Morell, K.D., Hidalgo, P., and Fraceschi, P., 2015, Magmatic consequences of the transition from orthogonal to oblique subduction in Panama: Geochemistry, Geophysics, Geosystems 16: 4178-4208.

Rosenberg, C.L., Handy, M.R., 2000. Syntectonic melt pathways during simple shearing of a partially molten rock analogue (Norcamphor-Bensamide). Journal of Geophysical Research, 105(B2), 3135-3149.

Rubatto, D. 2002. Zircon trace element geochemistry: partitioning with garnet and the link between U-Pb ages and metamorphism. Chemical Geology 184: 123-138.

Sagong, H., Kwon, S.T., and Ree, J.T., 2005, Mesozoic episodic magmatism in South Korea and its tectonic implication. Tectonics 24: 18, TC5002.

Saint-Blanquat, M., Law, R.,D., Bouchez, J.L., Morgan, S., 2001. Internal structure and emplacement of the Papoose Flat pluton: An integrated structural, petrographic and magnetic susceptibility study. Geological Society of America Bulletin, 113(8), 975-995.

Salazar, C.A., Archanjo, C.J., Rodrigues, S.W., Hollanda, M.H.B.M., Liu, D., 2013. Age and magnetic fabric of the Três Córregos granite batholith: evidence for Ediacaran transtension in the Ribeira Belt (SE Brazil). International Journal of Earth Sciences, 102: 1563-1581. 
Sarmiento-Rojas, L.F., Van Wess, J.D., and Cloetingh, S., 2006, Mesozoic transtensional basin history of the Eastern Cordillera, Colombian Andes: Inferences from tectonic models. Journal of South American Earth Sciences 21: 383-411.

Saylor, J.E., Horton, B., Nie, J., Corredor, J., and Mora, A., 2011. Evaluating foreland basin partitioning in the Northern Andes using Cenozoic fill of the Floresta Basin, Eastern Cordillera, Colombia. Basin Research 23: 377-402.

Schaltegger, U., Brack, P., Ovtcharova, M., Peytcheva, I., Schoene, B., Stracke, A., Marocchi, M., Bargossi, G.M., 2009. Zircon and titanite recording 1.5 million years of magma accretion, crystallization and initial cooling in a composite pluton (southern Adamello batholith, northern Italy). Earth and Planetary Science Letters 286: 208-218.

Schmidt, M.W. and Poli, S., 2004. Magmatic epidote. In 'Epidotes', Liebscher, A. \& Franz, G. ed. Mineralogical Society of America and Geochemical Society, Washington, DC, $399-430$.

Schopa, A., Floess, D., Saint Blanquat, M., Annen, C., Launeau, P., 2015. The relation between magnetite and silicate fabric in granitoids of the Adamello Batholith. Tectonophysics 642: 1-15.

Schwartz, J.J., Johnson, K., Miranda, E.A., Wooden, J.L., 2011. The generation of high Sr/Y plutons following Late Jurassic arc-arc collision, Blue Mountains province, NE Oregon. Lithos 126: 22-41.

Seton, M., Müller, R. D., Zahirovic, S., Gaina, C., Torsvik, T., Shephard, G., Talsma, A., Gurnes, M., Turner, M., and Chandler, M., 2012. Global continental and ocean basin reconstructions since $200 \mathrm{Ma}$. Earth Science Reviews 113: 212-270

Shand, S.J., 1943, Eruptive Rocks, their genesis, composition, classification, and their relation to ore-deposits with a chapter on meteorite: John Wiley \& Sons., New York, 450 p.

Sillitoe, R.H., Jaramillo, L., Damon, P.E., Shafiquillah, M., Escobar, R., 1982. Setting, characteristics and age of the Andean Porphyry Copper Belt in Colombia. Economic Geology 77: 1837-1850.

Silva, A., Mora, A., Caballero, V., Rodríguez, G., Ruiz, G., Moreno, N., Parra, M., RamírezArias, J.C., Ibáñez, M., and Quintero, I., 2013. Tectonic controls on sedimentation in an intermontane hinterland basin adjacent to inversion structures: the Nuevo Mundo syncline, Middle Magdalena Valley, Colombia: in: Nemčok, M., Mora, A., and Cosgrove, J.W., eds., Thick-skin-dominated orogens: from initial inversion to full accretion: London, Geological Society [London], Special Publication 377: 369-409.

Sláma, J., Košler, J., Condon, D.J., Crowley, J.L., Gerdes, A., Hanchar, J.M., Horstwood, M.S.A., Morris, G.A., Nasdala, L., Norberg, N., Schaltegger, U., Schoene, B., Tubrett, M.N., and Whitehouse. M.J., 2008, Plešovice zircon - A new natural reference material for U-Pb and $\mathrm{Hf}$ isotopic microanalysis. Chemical Geology 249: 1-35. 
Spadea, P., Espinosa, A., 1996. Petrology and chemistry of late Cretaceous volcanic rocks from the southernmost segment of the Western Cordillera of Colombia (South America). Journal of South American Earth Sciences 9: 79-90.

Spikings, R., Cochrane, R., Villagómez, D., Van der Lelij, R., Vallejo, C., Winkler, W., and Beate, B., 2015, The geological history of northwestern South America: from Pangaea to the early collision of the Caribbean Large Igneous Province (290-75 Ma). Gondwana Research 27: 95-139.

Spikings, R.A., Winkler, W., Hughes, R.A., Handler, R., 2005. Thermochronology of Allochthonous Terranes in Ecuador: unraveling the accretionary and postaccretionary history of the Northern Andes. Tectonophysics 399: 195-220.

Spikings, R.A., Winkler, W., Seward, D. Handler, R., 2001. Along-strike variations in the thermal and tectonic response of the continental Ecuadorian Andes to the collision with heterogeneous oceanic crust. Earth and Planetary Science Letters 186: 57-73.

Stevenson, C.T.E., Owens, W.H., Hutton, D.H.W., 2007. Flow lobes in granite: The determination of magma flow direction in the Trawenagh Bay Granite, northwestern Ireland, using anisotropy of magnetic susceptibility. Geological Society of America Bulletin 119: 1368-1386.

Sun, S.S., and McDonough, W.F., 1989, Chemical and isotopic systematics of oceanic basalts: implications for mantle composition and processes. in Sanders, A.D., Norry, M.J., eds., Magmatism in oceanic basins: London, Geological Society [London], Special Publication 42: 313-345.

Tamura, Y., Tatsumi, Y., Zhao, D., Kido, Y., Shukuno, 2002. Hot fingers in the mantle wedge: new insights into magma genesis in subduction zones. Earth and Planetary Science Letters 197: 105-116

Tarney, J., and Jones, C.E., 1994. Trace element geochemistry of orogenic igneous rocks and crustal growth models: Journal of the Geological Society [London] 151: 855-868.

Tatsumi, Y. and Eggins, S., 1995. Subduction zone magmatism. Boston, Blackwell, Science, $211 \mathrm{p}$.

Tikoff, B., Saint-Blanquat, M., 1997. Transpressional shearing and strike-slip partitioning in the Late Cretaceous Sierra Nevada magmatic arc, California. Tectonics 16(3): 442-459.

Titus, S.J., Clark, R., Tikoff, B., 2005. Geologic and geophysical investigation of two finegrained granites, Sierra Nevada Batholith, California: Evidence for structural controls on emplacement and volcanism. Geological Society of America Bulletin 117: 1255-1271.

Toro-Toro, L.M., Moreno-Sánchez, M., Gómez, A., 2011, Geoquímica y petrografía de las rocas volcánicas de la formación Yaví. Boletín de Geología 33: 93-100. 
Torres, R.; Ruiz, J.; Patchett, P. J.; and Grajales, J. M. 1999. A Permo-Triassic continental arc in eastern Mexico: Tectonic implications for reconstructions of southern North America, in Bartolini, C., et al., eds., Mesozoic sedimentary and tectonic history of northcentral Mexico. Geological Society of America Special Paper 340: 191-196.

Toussaint, J.F. 1995. Evolución Geológica de Colombia: Triásico-Jurásico: Editorial Universidad Nacional, Medellín, 277 p.

Toussaint, J.F.; and Restrepo, J.J. 1989. Acreciones sucesivas en Colombia: un nuevo modelo de evolución geológica. In: Memorias V Congreso Colombiano de Geología, p. 127-146.

Trindade, R.I.F., Raposo, M.I.B., Ernesto, M., Siqueira, R., 1999. Magnetic susceptibility and partial anhysteretic remanence anisotropies in the magnetite-bearing granite pluton of Tourão, NE Brazil. Tectonophysics 314: 443-468.

Tschanz, C.M., Marvin, R.F., Cruz, J., Mehnert, H.H., Cebula, G.T, 1974. Geologic evolution of the Sierra Nevada de Santa Marta area, Colombia. Geological Society of America Bulletin 85: 273-284.

Tschanz, C.M., Jimeno, A., Vesga, C., 1969. Geology of the Sierra Nevada de Santa Marta area (Colombia). Instituto de Investigaciones e Información Geocientífica, Minero Ambiental y Nuclear. República de Colombia. 288 pp.

Usui, Y., Nakamura, N., Yoshida, T., 2006. Magnetite microexsolution in silicate and magmatic flow fabric of the Goyozan granitoid (NE Japan): significance of partial remanence anisotropy. Journal of Geophysical Research, vol 111, B11101.

Usui, Y., Shibuya, T., Sawaki, Y., Komiya, T., 2015. Rock magnetism of tiny exsolved magnetite in plagioclase from a Paleoarchean granitoid in the Pilbara craton. Geochemistry, Geophysics, Geosystems 16: 112-125.

Vallejo, C., Spikings, R.A., Winkler, W., Luzieux, L., Chew, D., Page, L., 2006. The early interaction between the Caribbean Plateau and the NW South American plate. Terra Nova 18: 264-269.

Van der Lelij, R., Spikings, R., Ulianov, A., Chiaradia, M., and Mora, A., 2016. Palaeozoic to Early Jurassic history of the northwestern corner of Gondwana, and implications for the evolution of the Iapetus, Rheic and Pacific Oceans. Gondwana Research 31: 271-294.

van Hunen, J., ven de Berg, A.P., Vlaar, N.J., 2011. Various mechanisms to induce presentday shallow flat subduction and implications for the younger Earth: a numerical parameter study. Physics of the Earth and Planetary Interiors 146: 179-194.

Vásquez, M., Altenberger; U., Romer, L.R., Sudo, M., and Moreno-Murillo, J.M., 2009. Magmatic evolution of the Andean Eastern Cordillera of Colombia during the Cretaceous: Influence of previous tectonic processes. Journal of South American Earth Sciences 29: 171-186. 
Vásquez, M., and Altenberger, U., 2005. Mid-Cretaceous extension-related magmatism in the eastern Colombian Andes. Journal of South American Earth Sciences 20: 193-210.

Vervoort, J.,D., Kemp, A.I.S., Fisher, C., Bauer, A., 2015. The rock record has it about right-no significant continental crust formation prior to $3.8 \mathrm{Ga}$. American Geophysical Union, Fall Meeting, San Francisco, Abstracts.

Vervoort, J.D., and Blichert-Toft, J., 1999. Evolution of the depleted mantle: Hf isotope evidence from juvenile rocks through time. Geochimica et Cosmochimica Acta 63: 533556.

Vervoort, J.D., Patchett, P.J., 1996. Behavior of hafnium and neodymium isotopes in the crust: constraints from Precambrian crustally derived granites. Geochimica et Cosmochimica Acta 60: 3717-3733.

Vervoort, J.D., Patchett, P.J., Albarede, F., Blichert-Toft, J., Rudnick, R., and Downes, H., 2000. Hf-Nd isotopic evolution of the lower crust. Earth and Planetary Science Letters 181: 115-129.

Vervoort, J.D., Patchett, P.J., Söderlund, U., and Baker, M., 2004. Isotopic composition of Yb and the determination of $\mathrm{Lu}$ concentrations and $\mathrm{Lu} / \mathrm{Hf}$ ratios by isotope dilution using MC-ICPMS: Geochemistry, Geophysics, Geosystems 5: 15.

Vesga, C.J., and Barrero, D., 1978. Edades K/Ar en rocas ígneas y metamórficas de la Cordillera Central de Colombia y su implicación geológica. Congreso Colombiano de Geología, 2nd, Bogotá, Abstracts, p. 17.

Villagomez, D., and Spikings, R., 2013. Thermochronology and tectonics of the Central and Western Cordilleras of Colombia: Early Cretaceous-Tertiary evolution of the Northern Andes. Lithos 160-161: 228-249.

Villagomez, D., Spikings, R., Magna, T., Kammer, A., Winkler, W., and Beltrán, A., 2011. Geochronology, geochemistry and tectonic evolution of Western and Central cordilleras of Colombia. Lithos 125: 875-896.

Villamil, T., 1999. Campanian-Miocene Tectonostratigraphy, Depocenter evolution and basin development of Colombia and Western Venezuela. Palaeogeography, Palaeoclimatology, Palaeoecology 153, 239-275.

Vinasco, C.; Cordani, U.; González, H.; Weber, M.; and Peláez, C. 2006. Geochronological, isotopic, and geochemical data from Permo-Triassic granitic gneisses and granitoids of the Colombian Central Andes. Journal of South American Earth Sciences 21: 355-371.

Vogt, K., Castro, A., and Gerya, T., 2013. Numerical modeling of geochemical variations caused by crustal relamination: Geochemistry, Geophysics, Geosystems 14: 470-487.

Weber, M., Gómez-Tapias, J., Cardona, A., Duarte, E., Pardo-Trujillo, A., Valencia, V.A., 2015. Geochemistry of the Santa Fe Batholith and Buritica Tonalite in NW Colombia e Evidence of subduction initiation beneath the Colombian Caribbean Plateau. Journal of South American Earth Scienes 62: 257-274. 
Wei, W., Chen, Y., Faure, M., Shi, Y.H., Martelet, G., 2014. A multidisciplinary study on the emplacement mechanism of the Qingyang-Jiuhua Massif in Southeast China and its tectonic bearings. Part I: structural geology, AMS and paleomagnetism. Journal of Southeast Asian Earth Sciences 86: 76-93.

White W.M., Albarède, F., and Télouk, P., 2000. High-precision analysis of Pb isotopic ratios using multi-collector ICP-MS. Chemical Geology 167: 227-257.

Williams, I.S., 1998, U-Th-Pb geochronology by ion microprobe, in: McKibben, M.A., ShanksIII III, W.C., and Ridley, W.I., eds., Applications of Microanalytical Techniques to Understanding Mineralizing Processes. Reviews in Economic Geology 7: 1-35.

Wilson, J., 1998. Magnetic susceptibility patterns in the Cordilleran granitoid: The Las Tazas Complex, northern Chile. Journal of Geophysical Research 103 (B3): 5257-5267.

Wilson, J., Groccot, J., 1999. The emplacement of the granitic Las Tazas complex, northern Chile: the relationship between local and regional strain. Journal of Structural Geology. 21: 1513-1523.

Zapata, S., Cardona, A., Jaramillo, C., Valencia, V., and Vervoort, J., 2016. U-Pb LA-ICPMS geochronology and geochemistry of Jurassic volcanic and plutonic rocks from the Putumayo region (southern Colombia): tectonic setting and regional correlations. Boletín de Geología 38: 1-38.

Zartman, R.E., and Doe, S.M., 1981, Plumbotectonics - the model. Tectonophysics 75: 135162.

Zuluaga, C., Stowell, H., 2012. Late Cretaceous-Paleocene metamorphic evolution of the Sierra Nevada de Santa Marta: Implications for Caribbean geodynamic evolution. Journal of South American Earth Sciences 14: 1-9. 
ANEXOS 
Table 2.1. U-Pb zircon ages from the Tierradentro unit.

\begin{tabular}{|c|c|c|c|c|c|c|c|c|c|c|c|}
\hline Analysis & $\mathrm{Th} / \mathrm{U}$ & ${ }^{238} \mathrm{U} /{ }^{206} \mathrm{~Pb}$ & $\%$ err & ${ }^{207} \mathrm{~Pb} /{ }^{206} \mathrm{~Pb}$ & $\%$ err & $\mathrm{Age}^{206} \mathrm{~Pb} /{ }^{238} \mathrm{U}$ & abs error & $\mathrm{Age}^{207} \mathrm{~Pb} /{ }^{206} \mathrm{~Pb}$ & abs error & Age (Ma) & abs error (Ma) \\
\hline \multicolumn{12}{|c|}{ CAT1A } \\
\hline 40 & 0.15 & 27.0090 & 1.7 & 0.0513 & 0.9 & 234.4 & 4.0 & 254.9 & 19.6 & 234.4 & 4.0 \\
\hline 39 & 0.05 & 25.6958 & 1.9 & 0.0521 & 1.2 & 246.1 & 4.7 & 288.3 & 26.3 & 246.1 & 4.7 \\
\hline 38 & 0.10 & 28.8771 & 2.5 & 0.0484 & 2.1 & 219.5 & 5.3 & 116.6 & 49.2 & 219.5 & 5.3 \\
\hline 37 & 0.12 & 27.6399 & 2.0 & 0.0516 & 1.7 & 229.1 & 4.6 & 265.9 & 39.7 & 229.1 & 4.6 \\
\hline 36 & 0.22 & 27.6622 & 1.8 & 0.0513 & 1.1 & 228.9 & 4.0 & 254.2 & 24.6 & 228.9 & 4.0 \\
\hline 35 & 0.12 & 28.1342 & 2.0 & 0.0505 & 1.8 & 225.2 & 4.5 & 215.9 & 40.9 & 225.2 & 4.5 \\
\hline 34 & 0.22 & 27.4429 & 1.5 & 0.0526 & 1.5 & 230.7 & 3.4 & 310.8 & 33.6 & 230.7 & 3.4 \\
\hline 28 & 0.18 & 26.4232 & 0.9 & 0.051 & 0.9 & 239.5 & 2.2 & 239.6 & 20.9 & 239.5 & 2.2 \\
\hline 27 & 0.35 & 26.4917 & 1.3 & 0.0495 & 1.5 & 238.9 & 3.1 & 170.8 & 34.3 & 238.9 & 3.1 \\
\hline 26 & 0.08 & 27.7288 & 1.6 & 0.0501 & 1.7 & 228.4 & 3.5 & 201.9 & 38.5 & 228.4 & 3.5 \\
\hline 25 & 0.16 & 28.6917 & 0.9 & 0.0509 & 1.0 & 220.9 & 2.0 & 238.6 & 22.1 & 220.9 & 2.0 \\
\hline 23 & 0.19 & 28.0222 & 1.9 & 0.0531 & 1.8 & 226.0 & 4.2 & 331.0 & 41.0 & 226.0 & 4.2 \\
\hline 22 & 0.04 & 28.5203 & 3.3 & 0.0523 & 3.1 & 222.2 & 7.2 & 297.7 & 68.8 & 222.2 & 7.2 \\
\hline 21 & 0.19 & 26.2227 & 1.0 & 0.0503 & 1.0 & 241.3 & 2.4 & 207.2 & 22.3 & 241.3 & 2.4 \\
\hline 20 & 0.44 & 25.1953 & 2.1 & 0.052 & 1.7 & 250.9 & 5.2 & 284.1 & 39.5 & 250.9 & 5.2 \\
\hline 19 & 0.03 & 26.4145 & 1.5 & 0.0509 & 1.4 & 239.5 & 3.6 & 237.4 & 31.5 & 239.5 & 3.6 \\
\hline 18 & 0.15 & 26.0779 & 0.9 & 0.0506 & 0.8 & 242.6 & 2.2 & 224.2 & 17.3 & 242.6 & 2.2 \\
\hline 17 & 0.14 & 26.9842 & 1.5 & 0.0503 & 2.2 & 234.6 & 3.6 & 207.4 & 51.0 & 234.6 & 3.6 \\
\hline 16 & 0.17 & 28.8498 & 1.7 & 0.0514 & 1.8 & 219.7 & 3.6 & 258.6 & 40.0 & 219.7 & 3.6 \\
\hline 15 & 0.16 & 31.4358 & 1.7 & 0.0505 & 2.0 & 201.9 & 3.4 & 219.6 & 46.5 & 201.9 & 3.4 \\
\hline 14 & 0.15 & 26.1344 & 1.0 & 0.0506 & 1.2 & 242.1 & 2.4 & 224.5 & 27.5 & 242.1 & 2.4 \\
\hline 13 & 0.14 & 27.4278 & 1.8 & 0.0498 & 2.1 & 230.8 & 4.0 & 185.4 & 47.5 & 230.8 & 4.0 \\
\hline 11 & 0.04 & 25.7171 & 1.4 & 0.0555 & 1.6 & 245.9 & 3.3 & 430.5 & 34.6 & 245.9 & 3.3 \\
\hline 10 & 0.18 & 28.0903 & 1.6 & 0.0506 & 1.9 & 225.5 & 3.5 & 224.4 & 43.9 & 225.5 & 3.5 \\
\hline 9 & 0.25 & 26.3971 & 1.0 & 0.0511 & 1.1 & 239.7 & 2.3 & 243.4 & 25.3 & 239.7 & 2.3 \\
\hline
\end{tabular}




\begin{tabular}{|c|c|c|c|c|c|c|c|c|c|c|c|}
\hline 8 & 0.07 & 31.0071 & 5.7 & 0.0588 & 3.1 & 204.6 & 11.4 & 559.7 & 65.8 & 204.6 & 11.4 \\
\hline 5 & 0.20 & 26.6148 & 1.3 & 0.0505 & 1.3 & 237.8 & 3.0 & 217.7 & 30.1 & 237.8 & 3.0 \\
\hline 4 & 0.15 & 28.4656 & 1.5 & 0.0505 & 1.9 & 222.6 & 3.3 & 216.8 & 42.9 & 222.6 & 3.3 \\
\hline 3 & 0.12 & 26.4017 & 1.2 & 0.0507 & 1.3 & 239.7 & 2.8 & 228.8 & 29.9 & 239.7 & 2.8 \\
\hline 2 & 0.95 & 19.0297 & 1.8 & 0.0514 & 2.5 & 330.2 & 5.9 & 256.9 & 57.3 & 330.2 & 5.9 \\
\hline 1 & 0.87 & 19.2819 & 1.7 & 0.0537 & 2.3 & 325.9 & 5.3 & 356.6 & 50.8 & 325.9 & 5.3 \\
\hline \multicolumn{12}{|c|}{ GCC8 } \\
\hline 25 & & 26.9429 & 1.6 & 0.0515 & 0.8 & 234.9 & 3.8 & 265.1 & 17.4 & 234.9 & 3.8 \\
\hline 24 & & 25.9986 & 1.6 & 0.0516 & 0.6 & 243.3 & 3.7 & 266.7 & 13.1 & 243.3 & 3.7 \\
\hline 23 & & 26.4926 & 1.6 & 0.0512 & 0.6 & 238.8 & 3.7 & 248.6 & 13.3 & 238.8 & 3.7 \\
\hline 22 & & 26.699 & 1.6 & 0.0509 & 0.7 & 237.0 & 3.6 & 235.6 & 15.0 & 237.0 & 3.6 \\
\hline 21 & & 25.6548 & 1.6 & 0.0520 & 0.7 & 246.5 & 3.9 & 283.7 & 16.7 & 246.5 & 3.9 \\
\hline 19 & & 27.0936 & 1.7 & 0.0513 & 0.8 & 233.6 & 3.8 & 252.6 & 17.5 & 233.6 & 3.8 \\
\hline 18 & & 25.3305 & 1.6 & 0.0512 & 0.7 & 249.6 & 3.9 & 251.1 & 16.7 & 249.6 & 3.9 \\
\hline 16 & & 26.8629 & 1.7 & 0.0511 & 0.7 & 235.6 & 3.9 & 246.4 & 17.1 & 235.6 & 3.9 \\
\hline 13 & & 21.7673 & 2.4 & 0.0509 & 1.2 & 289.5 & 6.9 & 237.6 & 26.4 & 289.5 & 6.9 \\
\hline 11 & & 25.535 & 1.5 & 0.0514 & 0.9 & 247.6 & 3.6 & 261.0 & 21.3 & 247.6 & 3.6 \\
\hline 10 & & 24.7234 & 1.5 & 0.0512 & 0.8 & 255.6 & 3.6 & 248.7 & 18.8 & 255.6 & 3.6 \\
\hline 8 & & 26.0174 & 1.7 & 0.0513 & 1.1 & 243.1 & 4.0 & 255.9 & 25.0 & 243.1 & 4.0 \\
\hline 7 & & 26.3151 & 1.4 & 0.0517 & 1.0 & 240.4 & 3.3 & 271.7 & 22.5 & 240.4 & 3.3 \\
\hline 6 & & 28.6658 & 1.8 & 0.0511 & 1.0 & 221.0 & 4.0 & 245.1 & 22.6 & 221.0 & 4.0 \\
\hline 5 & & 25.3365 & 1.4 & 0.0514 & 0.9 & 249.5 & 3.4 & 260.8 & 20.2 & 249.5 & 3.4 \\
\hline 4 & & 25.8257 & 1.5 & 0.0511 & 1.0 & 244.9 & 3.6 & 243.8 & 22.9 & 244.9 & 3.6 \\
\hline 3 & & 27.5677 & 1.5 & 0.0514 & 0.8 & 229.7 & 3.4 & 259.3 & 19.0 & 229.7 & 3.4 \\
\hline 2 & & 26.1818 & 1.6 & 0.0520 & 1.2 & 241.6 & 3.9 & 285.7 & 26.5 & 241.6 & 3.9 \\
\hline 1 & & 24.4290 & 1.6 & 0.0518 & 0.8 & 258.6 & 4.1 & 277.5 & 18.7 & 258.6 & 4.1 \\
\hline \multicolumn{12}{|c|}{ CI12 } \\
\hline 79 & 0.69 & 22.9375 & 0.9 & 0.0518 & 1.1 & 275.1 & 2.5 & 276.4 & 25.0 & 275.1 & 2.5 \\
\hline 78 & 0.78 & 23.5812 & 0.9 & 0.0509 & 1.2 & 267.7 & 2.4 & 234.4 & 27.0 & 267.7 & 2.4 \\
\hline
\end{tabular}




\begin{tabular}{|c|c|c|c|c|c|c|c|c|c|c|c|}
\hline 77 & 0.80 & 23.0767 & 0.9 & 0.0513 & 1.1 & 273.5 & 2.5 & 255.5 & 25.6 & 273.5 & 2.5 \\
\hline 76 & 0.21 & 26.4683 & 0.9 & 0.0525 & 0.9 & 239.1 & 2.1 & 306.6 & 19.8 & 239.1 & 2.1 \\
\hline 75 & 0.73 & 24.9916 & 0.9 & 0.0516 & 1.2 & 252.9 & 2.3 & 268.3 & 26.7 & 252.9 & 2.3 \\
\hline 74 & 0.65 & 23.4321 & 0.9 & 0.0517 & 0.8 & 269.4 & 2.3 & 274.1 & 18.5 & 269.4 & 2.3 \\
\hline 73 & 0.75 & 22.5919 & 0.9 & 0.0522 & 1.1 & 279.2 & 2.5 & 294.7 & 25.9 & 279.2 & 2.5 \\
\hline 72 & 0.90 & 23.7758 & 1.0 & 0.0515 & 1.2 & 265.6 & 2.6 & 264.9 & 26.7 & 265.6 & 2.6 \\
\hline 71 & 1.04 & 23.7701 & 0.9 & 0.0516 & 0.8 & 265.6 & 2.3 & 269 & 18.8 & 265.6 & 2.3 \\
\hline 70 & 0.99 & 23.5769 & 0.9 & 0.0526 & 1.0 & 267.8 & 2.5 & 311.4 & 23.5 & 267.8 & 2.5 \\
\hline 69 & 0.73 & 23.3647 & 0.9 & 0.0528 & 1.1 & 270.2 & 2.5 & 321.3 & 24.4 & 270.2 & 2.5 \\
\hline 68 & 0.84 & 23.1179 & 0.9 & 0.0519 & 1.0 & 273.0 & 2.4 & 280.4 & 22.8 & 273.0 & 2.4 \\
\hline 67 & 0.67 & 23.6224 & 1.0 & 0.0524 & 1.4 & 267.3 & 2.6 & 304.6 & 32.4 & 267.3 & 2.6 \\
\hline 66 & 0.45 & 33.2901 & 1.2 & 0.0510 & 1.2 & 190.8 & 2.3 & 241.4 & 28.2 & 190.8 & 2.3 \\
\hline 65 & 0.81 & 23.0809 & 0.9 & 0.0522 & 1.2 & 273.4 & 2.4 & 295.3 & 27.7 & 273.4 & 2.4 \\
\hline 64 & 0.92 & 23.5361 & 0.9 & 0.0532 & 1.0 & 268.2 & 2.4 & 336.7 & 22.5 & 268.2 & 2.4 \\
\hline 63 & 0.87 & 23.7377 & 0.9 & 0.0521 & 1.0 & 266.0 & 2.3 & 288.3 & 21.9 & 266.0 & 2.3 \\
\hline 62 & 0.87 & 23.1599 & 0.9 & 0.0517 & 1.1 & 272.5 & 2.5 & 273.5 & 24.1 & 272.5 & 2.5 \\
\hline 61 & 0.73 & 22.8918 & 0.9 & 0.0516 & 1.1 & 275.6 & 2.5 & 267.5 & 25.8 & 275.6 & 2.5 \\
\hline 60 & 0.81 & 23.0818 & 0.9 & 0.0513 & 1.1 & 273.4 & 2.5 & 254.1 & 25.2 & 273.4 & 2.5 \\
\hline 59 & 0.91 & 23.6421 & 0.9 & 0.0513 & 1.1 & 267.1 & 2.4 & 255.1 & 25.4 & 267.1 & 2.4 \\
\hline 58 & 0.65 & 22.7024 & 0.8 & 0.0517 & 0.8 & 277.9 & 2.3 & 274.3 & 18.3 & 277.9 & 2.3 \\
\hline 57 & 0.91 & 22.6733 & 0.9 & 0.0561 & 1.0 & 278.2 & 2.5 & 457.1 & 21.8 & 278.2 & 2.5 \\
\hline 56 & 0.72 & 23.2912 & 0.9 & 0.0517 & 1.2 & 271.0 & 2.4 & 271.4 & 26.8 & 271.0 & 2.4 \\
\hline 55 & 0.76 & 23.3666 & 0.9 & 0.0515 & 1.2 & 270.1 & 2.4 & 264.5 & 26.6 & 270.1 & 2.4 \\
\hline 54 & 0.58 & 23.6053 & 1.0 & 0.0520 & 1.0 & 267.5 & 2.6 & 285.1 & 22.7 & 267.5 & 2.6 \\
\hline 53 & 0.67 & 24.2324 & 1.0 & 0.0508 & 1.2 & 260.7 & 2.5 & 231.1 & 26.5 & 260.7 & 2.5 \\
\hline 52 & 0.53 & 23.3557 & 0.8 & 0.0524 & 0.9 & 270.3 & 2.2 & 304.1 & 20.5 & 270.3 & 2.2 \\
\hline 51 & 0.66 & 23.011 & 0.9 & 0.0526 & 1.2 & 274.2 & 2.5 & 312.1 & 26.5 & 274.2 & 2.5 \\
\hline 50 & 0.77 & 23.4416 & 0.9 & 0.0516 & 0.9 & 269.3 & 2.3 & 267 & 20.9 & 269.3 & 2.3 \\
\hline 49 & 0.98 & 23.7793 & 0.8 & 0.0514 & 1.0 & 265.5 & 2.2 & 259.8 & 22.9 & 265.5 & 2.2 \\
\hline 48 & 0.59 & 23.8253 & 1.0 & 0.0506 & 1.2 & 265.0 & 2.6 & 221.4 & 27.0 & 265.0 & 2.6 \\
\hline
\end{tabular}




\begin{tabular}{|c|c|c|c|c|c|c|c|c|c|c|c|}
\hline 47 & 0.90 & 23.6691 & 0.9 & 0.0557 & 1.1 & 266.8 & 2.4 & 442.4 & 24.5 & 266.8 & 2.4 \\
\hline 46 & 0.73 & 23.5727 & 1.0 & 0.0525 & 1.1 & 267.8 & 2.6 & 308 & 24.1 & 267.8 & 2.6 \\
\hline 45 & 0.98 & 23.2191 & 0.9 & 0.0523 & 1.1 & 271.8 & 2.5 & 297.4 & 25.7 & 271.8 & 2.5 \\
\hline 44 & 0.72 & 22.8482 & 1.0 & 0.0520 & 1.3 & 276.1 & 2.7 & 284.6 & 29.7 & 276.1 & 2.7 \\
\hline 43 & 0.77 & 22.786 & 1.0 & 0.0519 & 1.1 & 276.9 & 2.8 & 280.3 & 24.3 & 276.9 & 2.8 \\
\hline 42 & 0.68 & 23.4715 & 1.0 & 0.0520 & 1.1 & 269.0 & 2.5 & 285.4 & 24.1 & 269.0 & 2.5 \\
\hline 41 & 0.69 & 23.1648 & 0.9 & 0.0525 & 0.9 & 272.4 & 2.5 & 306.6 & 21.2 & 272.4 & 2.5 \\
\hline 40 & 0.98 & 23.1571 & 0.9 & 0.0521 & 1.1 & 272.5 & 2.3 & 289.2 & 25.0 & 272.5 & 2.3 \\
\hline 39 & 0.55 & 23.5479 & 1.0 & 0.0527 & 1.1 & 268.1 & 2.5 & 315.9 & 25.0 & 268.1 & 2.5 \\
\hline 38 & 0.70 & 23.583 & 0.9 & 0.0513 & 1.0 & 267.7 & 2.4 & 252.6 & 23.3 & 267.7 & 2.4 \\
\hline 37 & 0.95 & 23.2299 & 0.9 & 0.0512 & 1.0 & 271.7 & 2.5 & 247.6 & 22.3 & 271.7 & 2.5 \\
\hline 36 & 0.50 & 22.7884 & 1.0 & 0.0539 & 1.1 & 276.9 & 2.6 & 367.2 & 23.7 & 276.9 & 2.6 \\
\hline 35 & 0.73 & 22.6131 & 0.9 & 0.0520 & 0.8 & 279.0 & 2.4 & 287.4 & 19.1 & 279.0 & 2.4 \\
\hline 34 & 0.75 & 23.066 & 1.0 & 0.0522 & 1.1 & 273.6 & 2.6 & 293.7 & 24.1 & 273.6 & 2.6 \\
\hline 33 & 0.62 & 23.7828 & 0.9 & 0.0509 & 1.1 & 265.5 & 2.5 & 234.9 & 24.2 & 265.5 & 2.5 \\
\hline 32 & 0.81 & 23.8198 & 0.9 & 0.0530 & 1.1 & 265.1 & 2.5 & 330.2 & 24.1 & 265.1 & 2.5 \\
\hline 31 & 0.81 & 23.4793 & 1.0 & 0.0525 & 1.1 & 268.9 & 2.6 & 305.4 & 24.3 & 268.9 & 2.6 \\
\hline 30 & 0.83 & 22.7142 & 0.9 & 0.0517 & 1.0 & 277.7 & 2.5 & 271.4 & 22.9 & 277.7 & 2.5 \\
\hline 29 & 0.70 & 22.8694 & 1.1 & 0.0513 & 1.1 & 275.9 & 3.0 & 252.5 & 25.2 & 275.9 & 3.0 \\
\hline 28 & 0.81 & 22.8839 & 1.2 & 0.0522 & 1.3 & 275.7 & 3.4 & 294 & 28.5 & 275.7 & 3.4 \\
\hline 27 & 0.80 & 23.4882 & 1.1 & 0.0524 & 1.1 & 268.8 & 2.8 & 304 & 25.7 & 268.8 & 2.8 \\
\hline 26 & 0.94 & 23.3323 & 1.1 & 0.0515 & 0.9 & 270.5 & 2.9 & 264.1 & 20.0 & 270.5 & 2.9 \\
\hline 25 & 0.82 & 23.1315 & 1.1 & 0.0517 & 1.0 & 272.8 & 2.9 & 271.9 & 23.7 & 272.8 & 2.9 \\
\hline 24 & 0.69 & 22.8195 & 1.1 & 0.0525 & 1.1 & 276.5 & 2.9 & 306.4 & 25.2 & 276.5 & 2.9 \\
\hline 23 & 0.81 & 23.756 & 1.1 & 0.0516 & 1.1 & 265.8 & 2.9 & 269.1 & 25.2 & 265.8 & 2.9 \\
\hline 22 & 0.82 & 23.1042 & 1.2 & 0.0516 & 1.1 & 273.1 & 3.1 & 268.7 & 25.6 & 273.1 & 3.1 \\
\hline 21 & 0.86 & 23.5741 & 1.2 & 0.0519 & 1.0 & 267.8 & 3.0 & 282.3 & 22.3 & 267.8 & 3.0 \\
\hline 20 & 0.93 & 24.0124 & 1.1 & 0.0511 & 1.1 & 263.0 & 2.9 & 245.3 & 24.2 & 263.0 & 2.9 \\
\hline 19 & 0.64 & 24.7775 & 1.2 & 0.0504 & 1.0 & 255.1 & 3.0 & 214.4 & 23.4 & 255.1 & 3.0 \\
\hline 18 & 0.79 & 23.6868 & 1.1 & 0.0529 & 0.9 & 266.6 & 2.9 & 322.5 & 20.1 & 266.6 & 2.9 \\
\hline
\end{tabular}




\begin{tabular}{llllllllllll}
17 & 0.89 & 23.9576 & 1.1 & 0.0531 & 1.0 & 263.6 & 2.8 & 333.9 & 23.4 & 263.6 & 2.8 \\
16 & 0.47 & 28.1862 & 1.4 & 0.0647 & 1.5 & 224.7 & 3.1 & 763.8 & 30.5 & 224.7 & 3.1 \\
15 & 0.80 & 23.5825 & 1.0 & 0.0512 & 1.0 & 267.7 & 2.7 & 249.4 & 22.7 & 267.7 & 2.7 \\
14 & 0.73 & 23.5955 & 1.0 & 0.0517 & 0.8 & 267.6 & 2.6 & 270.9 & 17.8 & 267.6 & 2.6 \\
13 & 0.87 & 23.3662 & 1.1 & 0.0518 & 1.1 & 270.1 & 2.9 & 276.3 & 24.9 & 270.1 & 2.9 \\
12 & 0.71 & 22.754 & 1.2 & 0.0505 & 1.0 & 277.3 & 3.2 & 216.1 & 22.5 & 277.3 & 3.2 \\
11 & 0.72 & 21.9351 & 1.2 & 0.0524 & 1.1 & 287.4 & 3.3 & 304.2 & 23.9 & 287.4 & 3.3 \\
9 & 0.94 & 23.8755 & 1.2 & 0.0523 & 1.0 & 264.5 & 3.0 & 298.4 & 22.2 & 264.5 & 3.0 \\
8 & 0.13 & 34.2273 & 1.2 & 0.0506 & 0.8 & 185.6 & 2.2 & 224.9 & 18.1 & 185.6 & 2.2 \\
7 & 1.01 & 23.6109 & 1.2 & 0.0521 & 1.1 & 267.4 & 3.0 & 291.4 & 24.8 & 267.4 & 3.0 \\
6 & 0.58 & 22.5223 & 1.2 & 0.0506 & 0.9 & 280.1 & 3.2 & 223.2 & 21.8 & 280.1 & 3.2 \\
5 & 0.79 & 25.6777 & 1.1 & 0.0604 & 1.2 & 246.3 & 2.8 & 617.9 & 24.9 & 246.3 & 2.8 \\
4 & 0.93 & 23.249 & 1.1 & 0.0518 & 1.1 & 271.5 & 3.0 & 277.5 & 25.3 & 271.5 & 3.0 \\
3 & 0.47 & 25.3512 & 1.1 & 0.0509 & 0.9 & 249.4 & 2.8 & 236.4 & 19.7 & 249.4 & 2.8 \\
2 & 0.90 & 22.8461 & 1.1 & 0.0515 & 1.0 & 276.2 & 3.0 & 263.5 & 23.7 & 276.2 & 3.0 \\
1 & 0.61 & 23.5856 & 1.1 & 0.0512 & 0.8 & 267.7 & 2.9 & 251.3 & 19.3 & 267.7 \\
\hline
\end{tabular}


Table 2.2. U-Pb detrital zircon ages from the Cajamarca Complex.

\begin{tabular}{|c|c|c|c|c|c|c|c|c|c|c|c|}
\hline Analysis & $\mathrm{Th} / \mathrm{U}$ & ${ }^{238} \mathrm{U} /{ }^{206} \mathrm{~Pb}$ & $\%$ err & ${ }^{207} \mathrm{~Pb} /{ }^{206} \mathrm{~Pb}$ & $\begin{array}{c}\% \\
\text { err }\end{array}$ & Age ${ }^{206} \mathrm{~Pb} /{ }^{238} \mathrm{U}$ & abs error & Age ${ }^{207} \mathrm{~Pb} /{ }^{206} \mathrm{~Pb}$ & abs error & Age (Ma) & abs error $(\mathrm{Ma})$ \\
\hline 98 & 1.53 & 12.25 & 0.86 & 0.06 & 1.0 & 505.84 & 4.20 & 622.88 & 20.78 & 505.8 & 4.2 \\
\hline 97 & 1.63 & 36.08 & 0.92 & 0.05 & 1.6 & 176.26 & 1.59 & 251.35 & 36.11 & 176.3 & 1.6 \\
\hline 96 & 0.83 & 24.15 & 1.14 & 0.05 & 0.8 & 261.53 & 2.92 & 310.06 & 17.11 & 261.5 & 2.9 \\
\hline 94 & 0.84 & 4.20 & 1.36 & 0.09 & 0.9 & 1376.91 & 16.79 & 1473.30 & 16.74 & 1473.3 & 16.7 \\
\hline 93 & 0.53 & 37.49 & 0.81 & 0.05 & 1.0 & 169.68 & 1.36 & 346.31 & 22.24 & 169.7 & 1.4 \\
\hline 92 & 0.14 & 10.18 & 0.87 & 0.07 & 0.6 & 603.89 & 5.04 & 817.92 & 12.83 & 603.9 & 5.0 \\
\hline 90 & 0.91 & 38.51 & 0.77 & 0.07 & 1.4 & 165.28 & 1.26 & 885.00 & 28.37 & 165.3 & 1.3 \\
\hline 89 & 0.67 & 37.95 & 0.96 & 0.05 & 1.1 & 167.68 & 1.59 & 239.48 & 25.92 & 167.7 & 1.6 \\
\hline 87 & 0.50 & 11.84 & 0.76 & 0.06 & 0.7 & 522.89 & 3.80 & 534.97 & 15.16 & 522.9 & 3.8 \\
\hline 86 & 0.30 & 2.13 & 0.91 & 0.18 & 0.5 & 2482.86 & 18.79 & 2606.43 & 8.13 & 2606.4 & 8.1 \\
\hline 85 & 0.04 & 9.19 & 1.43 & 0.06 & 1.5 & 666.14 & 9.04 & 655.53 & 31.86 & 666.1 & 9.0 \\
\hline 84 & 0.63 & 10.98 & 0.88 & 0.06 & 0.7 & 561.80 & 4.73 & 555.47 & 16.00 & 561.8 & 4.7 \\
\hline 83 & 0.69 & 9.59 & 0.72 & 0.06 & 0.7 & 639.30 & 4.39 & 686.62 & 14.45 & 639.3 & 4.4 \\
\hline 82 & 0.53 & 5.95 & 1.23 & 0.08 & 0.8 & 1000.93 & 11.44 & 1173.72 & 16.00 & 1173.7 & 16.0 \\
\hline 81 & 0.96 & 37.40 & 0.90 & 0.05 & 1.1 & 170.12 & 1.51 & 151.68 & 24.58 & 170.1 & 1.5 \\
\hline 80 & 0.57 & 40.00 & 1.66 & 0.05 & 3.4 & 159.18 & 2.61 & 373.90 & 75.48 & 159.2 & 2.6 \\
\hline 79 & 0.57 & 11.07 & 0.72 & 0.06 & 0.6 & 557.52 & 3.84 & 590.12 & 12.40 & 557.5 & 3.8 \\
\hline 78 & 0.44 & 3.55 & 0.87 & 0.10 & 0.5 & 1600.73 & 12.27 & 1598.74 & 9.65 & 1598.7 & 9.7 \\
\hline 77 & 0.47 & 3.58 & 0.74 & 0.11 & 0.5 & 1587.83 & 10.39 & 1730.00 & 8.75 & 1730.0 & 8.7 \\
\hline 76 & 0.65 & 36.32 & 0.95 & 0.05 & 1.0 & 175.08 & 1.63 & 286.31 & 23.41 & 175.1 & 1.6 \\
\hline 75 & 0.69 & 17.48 & 0.77 & 0.06 & 0.8 & 358.68 & 2.68 & 446.79 & 18.77 & 358.7 & 2.7 \\
\hline 74 & 0.50 & 9.55 & 0.79 & 0.06 & 0.8 & 642.22 & 4.80 & 709.70 & 17.82 & 642.2 & 4.8 \\
\hline 73 & 0.53 & 5.38 & 0.75 & 0.08 & 0.6 & 1098.32 & 7.59 & 1110.41 & 11.56 & 1110.4 & 11.6 \\
\hline 72 & 0.76 & 3.93 & 0.97 & 0.10 & 0.6 & 1460.72 & 12.72 & 1639.91 & 11.38 & 1639.9 & 11.4 \\
\hline 71 & 0.22 & 14.62 & 1.81 & 0.06 & 1.2 & 426.48 & 7.45 & 749.99 & 24.43 & 426.5 & 7.5 \\
\hline 69 & 0.96 & 38.32 & 0.73 & 0.05 & 0.8 & 166.05 & 1.20 & 159.08 & 18.18 & 166.1 & 1.2 \\
\hline 68 & 1.18 & 34.65 & 0.93 & 0.05 & 1.0 & 183.43 & 1.68 & 263.63 & 23.25 & 183.4 & 1.7 \\
\hline
\end{tabular}




\begin{tabular}{|c|c|c|c|c|c|c|c|c|c|c|c|}
\hline 67 & 0.45 & 5.53 & 0.91 & 0.08 & 1.0 & 1070.96 & 8.94 & 1102.57 & 19.49 & 1102.6 & 19.5 \\
\hline 66 & 0.20 & 9.60 & 0.67 & 0.06 & 0.6 & 639.04 & 4.05 & 631.41 & 11.91 & 639.0 & 4.0 \\
\hline 65 & 0.76 & 5.63 & 0.77 & 0.07 & 0.7 & 1053.54 & 7.44 & 1048.84 & 13.80 & 1048.8 & 13.8 \\
\hline 64 & 2.07 & 7.26 & 0.75 & 0.07 & 0.6 & 832.14 & 5.87 & 809.68 & 12.14 & 832.1 & 5.9 \\
\hline 62 & 0.69 & 18.36 & 0.98 & 0.05 & 0.8 & 341.85 & 3.27 & 379.91 & 17.82 & 341.8 & 3.3 \\
\hline 61 & 0.54 & 11.43 & 0.96 & 0.06 & 0.6 & 540.87 & 5.00 & 521.93 & 13.80 & 540.9 & 5.0 \\
\hline 60 & 0.29 & 5.83 & 1.02 & 0.07 & 0.6 & 1020.22 & 9.58 & 1021.56 & 12.32 & 1021.6 & 12.3 \\
\hline 59 & 0.66 & 12.89 & 1.04 & 0.06 & 0.9 & 481.64 & 4.82 & 468.23 & 20.74 & 481.6 & 4.8 \\
\hline 58 & 1.09 & 3.49 & 0.88 & 0.10 & 0.6 & 1625.21 & 12.57 & 1709.18 & 10.41 & 1709.2 & 10.4 \\
\hline 57 & 0.20 & 12.71 & 1.07 & 0.06 & 0.7 & 488.12 & 5.02 & 714.25 & 15.23 & 488.1 & 5.0 \\
\hline 56 & 0.42 & 3.96 & 0.91 & 0.09 & 0.6 & 1451.15 & 11.87 & 1437.95 & 11.16 & 1438.0 & 11.2 \\
\hline 55 & 0.57 & 23.42 & 1.06 & 0.05 & 1.2 & 269.48 & 2.78 & 313.58 & 26.73 & 269.5 & 2.8 \\
\hline 54 & 1.58 & 33.48 & 1.11 & 0.05 & 1.4 & 189.75 & 2.08 & 127.73 & 31.80 & 189.8 & 2.1 \\
\hline 53 & 0.34 & 20.13 & 0.79 & 0.06 & 0.6 & 312.47 & 2.40 & 446.32 & 13.29 & 312.5 & 2.4 \\
\hline 52 & 0.77 & 3.94 & 0.94 & 0.11 & 0.5 & 1459.19 & 12.33 & 1725.11 & 9.91 & 1725.1 & 9.9 \\
\hline 51 & 0.49 & 11.13 & 0.91 & 0.06 & 0.7 & 554.78 & 4.83 & 676.74 & 14.46 & 554.8 & 4.8 \\
\hline 50 & 0.85 & 7.99 & 0.85 & 0.07 & 0.6 & 760.38 & 6.09 & 808.72 & 12.10 & 760.4 & 6.1 \\
\hline 49 & 0.72 & 9.64 & 0.81 & 0.06 & 0.5 & 635.96 & 4.89 & 634.71 & 11.55 & 636.0 & 4.9 \\
\hline 48 & 0.34 & 5.14 & 0.85 & 0.08 & 0.5 & 1145.86 & 8.88 & 1161.19 & 9.94 & 1161.2 & 9.9 \\
\hline 47 & 0.43 & 6.29 & 0.86 & 0.07 & 0.6 & 950.48 & 7.61 & 1034.23 & 11.63 & 1034.2 & 11.6 \\
\hline 46 & 1.32 & 9.65 & 0.84 & 0.06 & 0.5 & 635.77 & 5.10 & 630.78 & 11.23 & 635.8 & 5.1 \\
\hline 45 & 0.75 & 39.12 & 1.06 & 0.05 & 1.2 & 162.71 & 1.70 & 212.19 & 26.72 & 162.7 & 1.7 \\
\hline 44 & 0.66 & 38.96 & 1.08 & 0.06 & 1.1 & 163.37 & 1.75 & 485.68 & 24.33 & 163.4 & 1.7 \\
\hline 43 & 1.48 & 35.41 & 1.29 & 0.05 & 1.8 & 179.53 & 2.28 & 238.23 & 40.02 & 179.5 & 2.3 \\
\hline 42 & 1.32 & 12.89 & 1.15 & 0.06 & 1.2 & 481.73 & 5.34 & 452.51 & 27.07 & 481.7 & 5.3 \\
\hline 41 & 0.76 & 5.49 & 1.32 & 0.08 & 0.7 & 1078.51 & 13.06 & 1211.55 & 13.39 & 1211.5 & 13.4 \\
\hline 40 & 0.40 & 3.06 & 0.97 & 0.11 & 0.6 & 1821.58 & 15.30 & 1864.75 & 10.81 & 1864.7 & 10.8 \\
\hline 39 & 0.36 & 4.91 & 0.98 & 0.08 & 0.6 & 1195.19 & 10.73 & 1196.51 & 12.53 & 1196.5 & 12.5 \\
\hline 38 & 0.65 & 38.07 & 1.29 & 0.05 & 1.1 & 167.16 & 2.13 & 162.42 & 26.08 & 167.2 & 2.1 \\
\hline 37 & 0.70 & 38.25 & 1.23 & 0.05 & 1.6 & 166.38 & 2.01 & 300.74 & 35.76 & 166.4 & 2.0 \\
\hline
\end{tabular}




\begin{tabular}{|c|c|c|c|c|c|c|c|c|c|c|c|}
\hline 36 & 0.75 & 22.42 & 1.09 & 0.05 & 1.2 & 281.29 & 2.99 & 279.27 & 28.01 & 281.3 & 3.0 \\
\hline 35 & 0.56 & 34.60 & 1.06 & 0.05 & 1.1 & 183.66 & 1.91 & 175.95 & 25.37 & 183.7 & 1.9 \\
\hline 34 & 1.32 & 12.71 & 1.00 & 0.06 & 1.1 & 488.40 & 4.69 & 514.47 & 23.12 & 488.4 & 4.7 \\
\hline 33 & 0.30 & 4.84 & 0.90 & 0.11 & 0.7 & 1211.01 & 9.95 & 1807.11 & 12.39 & 1807.1 & 12.4 \\
\hline 32 & 0.71 & 5.62 & 0.97 & 0.07 & 0.9 & 1055.12 & 9.42 & 1025.12 & 18.00 & 1025.1 & 18.0 \\
\hline 31 & 0.34 & 5.46 & 1.30 & 0.08 & 1.0 & 1084.88 & 12.97 & 1161.42 & 19.25 & 1161.4 & 19.2 \\
\hline 30 & 1.62 & 33.14 & 0.84 & 0.05 & 0.8 & 191.63 & 1.59 & 256.40 & 19.20 & 191.6 & 1.6 \\
\hline 29 & 0.52 & 4.20 & 1.21 & 0.16 & 0.7 & 1377.83 & 14.95 & 2415.38 & 12.41 & 2415.4 & 12.4 \\
\hline 28 & 0.65 & 21.47 & 1.09 & 0.06 & 0.9 & 293.46 & 3.13 & 416.62 & 19.94 & 293.5 & 3.1 \\
\hline 27 & 0.74 & 5.79 & 0.87 & 0.07 & 0.8 & 1026.74 & 8.30 & 1024.20 & 15.33 & 1024.2 & 15.3 \\
\hline 26 & 0.43 & 5.78 & 0.86 & 0.07 & 0.8 & 1028.66 & 8.16 & 1028.18 & 15.30 & 1028.2 & 15.3 \\
\hline 25 & 0.43 & 9.66 & 0.96 & 0.06 & 1.1 & 635.12 & 5.81 & 583.37 & 23.36 & 635.1 & 5.8 \\
\hline 24 & 0.04 & 5.98 & 0.79 & 0.07 & 0.6 & 996.27 & 7.31 & 1029.89 & 12.88 & 1029.9 & 12.9 \\
\hline 23 & 0.26 & 7.59 & 0.82 & 0.07 & 0.7 & 797.79 & 6.14 & 811.66 & 15.15 & 797.8 & 6.1 \\
\hline 22 & 0.75 & 25.80 & 1.17 & 0.05 & 1.0 & 245.19 & 2.82 & 264.76 & 23.33 & 245.2 & 2.8 \\
\hline 21 & 0.56 & 5.39 & 1.30 & 0.08 & 0.8 & 1097.49 & 13.13 & 1115.68 & 15.77 & 1115.7 & 15.8 \\
\hline 20 & 0.58 & 13.97 & 1.15 & 0.06 & 1.0 & 445.68 & 4.97 & 568.26 & 20.77 & 445.7 & 5.0 \\
\hline 19 & 0.45 & 37.91 & 1.09 & 0.05 & 0.8 & 167.85 & 1.80 & 207.93 & 19.56 & 167.8 & 1.8 \\
\hline 17 & 0.45 & 38.50 & 1.10 & 0.05 & 0.8 & 165.31 & 1.79 & 175.66 & 18.79 & 165.3 & 1.8 \\
\hline 15 & 0.74 & 13.51 & 1.11 & 0.06 & 0.7 & 460.40 & 4.94 & 477.32 & 16.06 & 460.4 & 4.9 \\
\hline 14 & 1.13 & 15.02 & 1.27 & 0.06 & 0.7 & 415.61 & 5.13 & 496.98 & 16.30 & 415.6 & 5.1 \\
\hline 13 & 0.61 & 38.80 & 1.21 & 0.05 & 1.4 & 164.03 & 1.96 & 145.94 & 33.16 & 164.0 & 2.0 \\
\hline 12 & 0.39 & 39.25 & 1.29 & 0.05 & 1.9 & 162.18 & 2.06 & 355.31 & 41.50 & 162.2 & 2.1 \\
\hline 8 & 0.76 & 3.69 & 1.06 & 0.10 & 0.6 & 1544.21 & 14.59 & 1528.39 & 11.30 & 1528.4 & 11.3 \\
\hline 7 & 0.47 & 5.29 & 1.13 & 0.10 & 0.6 & 1116.69 & 11.58 & 1536.29 & 11.97 & 1536.3 & 12.0 \\
\hline 5 & 0.48 & 37.69 & 1.28 & 0.05 & 1.4 & 168.79 & 2.13 & 204.76 & 31.49 & 168.8 & 2.1 \\
\hline 4 & 0.41 & 5.61 & 1.13 & 0.08 & 0.7 & 1058.21 & 11.05 & 1151.63 & 14.17 & 1151.6 & 14.2 \\
\hline 3 & 0.05 & 6.05 & 1.06 & 0.08 & 0.6 & 985.83 & 9.66 & 1094.61 & 12.03 & 1094.6 & 12.0 \\
\hline 2 & 0.48 & 38.77 & 1.16 & 0.05 & 1.2 & 164.17 & 1.88 & 154.33 & 27.46 & 164.2 & 1.9 \\
\hline 1 & 1.04 & 39.17 & 1.14 & 0.05 & 0.9 & 162.50 & 1.83 & 159.26 & 20.33 & 162.5 & 1.8 \\
\hline
\end{tabular}


Table 2.3. Zircon Hf isotope data from the Tierradentro gneisses and amphibolites and micaschist from the Cajamarca Complex.

\begin{tabular}{|c|c|c|c|c|c|c|c|c|c|c|}
\hline${ }^{176} \mathrm{Hf} /{ }^{177} \mathrm{Hf}$ & 2SE & ${ }^{176} \mathrm{Lu} /{ }^{177} \mathrm{Hf}$ & $2 \mathrm{SE}$ & ${ }^{176} \mathrm{Yb} /{ }^{177} \mathrm{Hf}$ & 2SE & AGE & ${ }^{176} \mathrm{Hf} /{ }^{177} \mathrm{Hf}_{(\mathrm{i})}$ & $\varepsilon \mathrm{Hf}_{(0)}$ & $2 \mathrm{SE}$ & $\varepsilon \mathrm{Hf}_{(\mathrm{i})}$ \\
\hline \multicolumn{11}{|c|}{$\mathrm{CH} 21 \mathrm{C}$} \\
\hline 0.282604 & 0.000029 & 0.00180 & 0.00008 & 0.04890 & 0.00270 & 162.5 & 0.282599 & -6.4 & 1.0 & -3.0 \\
\hline 0.282768 & 0.000043 & 0.00261 & 0.00003 & 0.07213 & 0.00099 & 166.1 & 0.282760 & -0.6 & 1.5 & 2.8 \\
\hline 0.282613 & 0.000026 & 0.00214 & 0.00009 & 0.05680 & 0.00240 & 168.8 & 0.282606 & -6.1 & 0.9 & -2.6 \\
\hline 0.282733 & 0.000035 & 0.00168 & 0.00009 & 0.04580 & 0.00150 & 162.2 & 0.282728 & -1.8 & 1.2 & 1.6 \\
\hline 0.282703 & 0.000035 & 0.00220 & 0.00003 & 0.05870 & 0.00150 & 164.0 & 0.282696 & -2.9 & 1.2 & 0.5 \\
\hline 0.282677 & 0.000026 & 0.00164 & 0.00007 & 0.04340 & 0.00220 & 165.3 & 0.282672 & -3.8 & 0.9 & -0.3 \\
\hline 0.282617 & 0.000039 & 0.00174 & 0.00010 & 0.04430 & 0.00160 & 167.8 & 0.282612 & -5.9 & 1.4 & -2.4 \\
\hline 0.282664 & 0.000039 & 0.00117 & 0.00012 & 0.03640 & 0.00600 & 167.2 & 0.282660 & -4.3 & 1.4 & -0.7 \\
\hline 0.282664 & 0.000040 & 0.00145 & 0.00006 & 0.03860 & 0.00150 & 166.4 & 0.282659 & -4.3 & 1.4 & -0.7 \\
\hline 0.282415 & 0.000036 & 0.00113 & 0.00006 & 0.03160 & 0.00150 & 460.4 & 0.282405 & -13.1 & 1.3 & -3.2 \\
\hline 0.282016 & 0.000080 & 0.00112 & 0.00006 & 0.02590 & 0.00140 & 488.4 & 0.282006 & -27.2 & 2.8 & -16.7 \\
\hline 0.282265 & 0.000046 & 0.00111 & 0.00004 & 0.03350 & 0.00140 & 481.7 & 0.282255 & -18.4 & 1.6 & -8.0 \\
\hline 0.281923 & 0.000028 & 0.00085 & 0.00003 & 0.02360 & 0.00120 & 488.1 & 0.281915 & -30.5 & 1.0 & -19.9 \\
\hline 0.282253 & 0.000037 & 0.00085 & 0.00003 & 0.02282 & 0.00068 & 481.6 & 0.282245 & -18.8 & 1.3 & -8.4 \\
\hline 0.281894 & 0.000022 & 0.00092 & 0.00003 & 0.02700 & 0.00078 & 1536.3 & 0.281867 & -31.5 & 0.8 & 2.1 \\
\hline 0.281814 & 0.000031 & 0.00073 & 0.00004 & 0.02150 & 0.00120 & 1528.4 & 0.281793 & -34.3 & 1.1 & -0.7 \\
\hline 0.282713 & 0.000031 & 0.00190 & 0.00004 & 0.04694 & 0.00060 & 318.8 & 0.282702 & -2.5 & 1.1 & 4.1 \\
\hline 0.282444 & 0.000033 & 0.00166 & 0.00009 & 0.04630 & 0.00230 & 312.5 & 0.282434 & -12.1 & 1.2 & -5.5 \\
\hline 0.282544 & 0.000048 & 0.00138 & 0.00006 & 0.04120 & 0.00170 & 341.8 & 0.282535 & -8.5 & 1.7 & -1.2 \\
\hline 0.282461 & 0.000046 & 0.00129 & 0.00002 & 0.03522 & 0.00087 & 358.7 & 0.282452 & -11.5 & 1.6 & -3.8 \\
\hline 0.282444 & 0.000044 & 0.00075 & 0.00009 & 0.01910 & 0.00210 & 635.1 & 0.282435 & -12.1 & 1.6 & 1.8 \\
\hline 0.282172 & 0.000040 & 0.00123 & 0.00004 & 0.03930 & 0.00150 & 635.8 & 0.282157 & -21.7 & 1.4 & -8.0 \\
\hline 0.282410 & 0.000038 & 0.00081 & 0.00004 & 0.02470 & 0.00140 & 639.0 & 0.282400 & -13.3 & 1.3 & 0.7 \\
\hline 0.282181 & 0.000045 & 0.00082 & 0.00004 & 0.02169 & 0.00077 & 642.2 & 0.282171 & -21.4 & 1.6 & -7.4 \\
\hline 0.282194 & 0.000025 & 0.00160 & 0.00005 & 0.04720 & 0.00110 & 1094.6 & 0.282161 & -20.9 & 0.9 & 2.5 \\
\hline 0.282141 & 0.000034 & 0.00057 & 0.00009 & 0.01500 & 0.00180 & 1029.9 & 0.282130 & -22.8 & 1.2 & -0.1 \\
\hline
\end{tabular}




\begin{tabular}{ccccccccccc}
0.282033 & 0.000047 & 0.00089 & 0.00018 & 0.02520 & 0.00450 & 1025.1 & 0.282016 & -26.6 & 1.7 & -4.3 \\
0.280926 & 0.000062 & 0.00096 & 0.00004 & 0.02130 & 0.00088 & 2606.4 & 0.280878 & -65.7 & 2.2 & -8.2 \\
\hline \multicolumn{7}{c}{} & \multicolumn{1}{c}{ CAT1A } \\
\hline 0.282927 & 0.000028 & 0.00043 & 0.00002 & 0.00849 & 0.00034 & 201.9 & 0.282925 & 5.0 & 1.0 & 9.5 \\
0.282928 & 0.000032 & 0.00037 & 0.00000 & 0.00774 & 0.00011 & 225.5 & 0.282926 & 5.1 & 1.1 & 10.0 \\
0.282944 & 0.000030 & 0.00033 & 0.00003 & 0.00768 & 0.00065 & 230.7 & 0.282943 & 5.6 & 1.1 & 10.7 \\
0.282954 & 0.000029 & 0.00039 & 0.00000 & 0.00934 & 0.00014 & 225.2 & 0.282952 & 6.0 & 1.0 & 10.9 \\
0.282943 & 0.000027 & 0.00034 & 0.00001 & 0.00690 & 0.00037 & 228.9 & 0.282942 & 5.6 & 1.0 & 10.6 \\
0.282938 & 0.000025 & 0.00043 & 0.00003 & 0.00882 & 0.00059 & 226.0 & 0.282936 & 5.4 & 0.9 & 10.4 \\
0.282909 & 0.000029 & 0.00026 & 0.00001 & 0.00538 & 0.00026 & 219.7 & 0.282908 & 4.4 & 1.0 & 9.2 \\
0.282944 & 0.000027 & 0.00043 & 0.00001 & 0.00973 & 0.00024 & 234.4 & 0.282942 & 5.6 & 1.0 & 10.8 \\
\hline & & & & CI12 & & & & & & \\
\hline 0.282604 & 0.000026 & 0.00050 & 0.00002 & 0.01412 & 0.00054 & 267.7 & 0.282601 & -6.4 & 0.9 & -0.5 \\
0.282597 & 0.000029 & 0.00036 & 0.00002 & 0.00999 & 0.00052 & 246.3 & 0.282595 & -6.6 & 1.0 & -1.2 \\
0.282578 & 0.000022 & 0.00055 & 0.00002 & 0.01571 & 0.00080 & 267.4 & 0.282575 & -7.3 & 0.8 & -1.5 \\
0.282550 & 0.000021 & 0.00044 & 0.00002 & 0.01155 & 0.00069 & 266.6 & 0.282548 & -8.3 & 0.7 & -2.5 \\
0.282569 & 0.000023 & 0.00066 & 0.00003 & 0.01816 & 0.00063 & 265.5 & 0.282566 & -7.6 & 0.8 & -1.9 \\
0.282597 & 0.000025 & 0.00045 & 0.00001 & 0.01241 & 0.00014 & 267.5 & 0.282595 & -6.6 & 0.9 & -0.8 \\
0.282616 & 0.000031 & 0.00045 & 0.00003 & 0.01230 & 0.00110 & 269.3 & 0.282614 & -6.0 & 1.1 & -0.1 \\
0.282574 & 0.000022 & 0.00053 & 0.00001 & 0.01460 & 0.00020 & 275.1 & 0.282571 & -7.5 & 0.8 & -1.4
\end{tabular}


Table 3.1. U-Pb zircon ages from the Payandé, Ibagué and Mariquita plutons

\begin{tabular}{|c|c|c|c|c|c|c|c|c|c|c|c|c|}
\hline $\begin{array}{c}\text { Sample } \\
\text { name }\end{array}$ & $\begin{array}{c}\mathrm{U} \\
(\mathrm{ppm})\end{array}$ & $\mathrm{Th} / \mathrm{U}$ & ${ }^{238} \mathrm{U} /{ }^{206} \mathrm{~Pb}$ & $\begin{array}{l}1 \sigma \% \\
\text { error }\end{array}$ & ${ }^{207} \mathrm{~Pb} /{ }^{206} \mathrm{~Pb}$ & $\begin{array}{l}1 \sigma \% \\
\text { error }\end{array}$ & $\begin{array}{c}{ }^{206} \mathrm{~Pb} /{ }^{238} \mathrm{U} \\
\text { Age }\end{array}$ & $\begin{array}{c}\sigma \\
\text { absolute } \\
\text { error } \\
\end{array}$ & $\begin{array}{c}{ }^{207} \mathrm{~Pb} /{ }^{206} \mathrm{~Pb} \\
\mathrm{Age}\end{array}$ & $\begin{array}{c}1 \sigma \\
\text { absolute } \\
\text { error }\end{array}$ & $\begin{array}{l}\text { Best } \\
\text { age } \\
\text { (Ma) }\end{array}$ & $\begin{array}{l}1 \sigma \text { absolute } \\
\text { error }(\mathrm{Ma})\end{array}$ \\
\hline \multicolumn{13}{|c|}{ Payandé stock } \\
\hline \multicolumn{13}{|c|}{ CSP 3} \\
\hline CSP3_32 & 313.1 & 0.65 & 39.909 & 1.66 & 0.0495 & 1.49 & 159.5 & 2.6 & 172.3 & 34.5 & 159.5 & 2.6 \\
\hline CSP3_31 & 231.1 & 0.96 & 37.481 & 1.69 & 0.0491 & 1.69 & 169.7 & 2.8 & 151.8 & 39.1 & 169.7 & 2.8 \\
\hline CSP3_30 & 255.9 & 0.73 & 36.300 & 1.70 & 0.0486 & 1.55 & 175.2 & 2.9 & 129.0 & 36.0 & 175.2 & 2.9 \\
\hline CSP3_29 & 393.2 & 0.90 & 38.671 & 1.56 & 0.0491 & 1.37 & 164.6 & 2.5 & 150.4 & 31.8 & 164.6 & 2.5 \\
\hline CSP3_28 & 669.4 & 1.28 & 38.419 & 1.55 & 0.0492 & 1.15 & 165.6 & 2.5 & 157.7 & 26.6 & 165.6 & 2.5 \\
\hline CSP3_27 & 321.2 & 0.79 & 39.584 & 1.62 & 0.0503 & 1.60 & 160.8 & 2.6 & 208.4 & 36.6 & 160.8 & 2.6 \\
\hline CSP3_26 & 327.2 & 0.95 & 37.955 & 1.59 & 0.0491 & 1.47 & 167.6 & 2.6 & 152.3 & 34.1 & 167.6 & 2.6 \\
\hline CSP3_25 & 542.3 & 1.16 & 39.450 & 1.64 & 0.0554 & 1.71 & 161.4 & 2.6 & 428.9 & 37.7 & 161.4 & 2.6 \\
\hline CSP3_24 & 773.9 & 0.86 & 39.563 & 1.49 & 0.0474 & 2.93 & 160.9 & 2.4 & 71.8 & 68.3 & 160.9 & 2.4 \\
\hline CSP3_23 & 399.9 & 0.66 & 40.475 & 1.69 & 0.0487 & 3.30 & 157.3 & 2.6 & 132.1 & 75.9 & 157.3 & 2.6 \\
\hline CSP3_22 & 233.4 & 0.81 & 38.823 & 1.57 & 0.0481 & 3.12 & 163.9 & 2.5 & 105.6 & 72.0 & 163.9 & 2.5 \\
\hline CSP3_21 & 262.9 & 0.84 & 41.904 & 1.48 & 0.0487 & 3.11 & 152.0 & 2.2 & 135.4 & 71.6 & 152.0 & 2.2 \\
\hline CSP3_20 & 290.3 & 0.71 & 38.268 & 1.49 & 0.0492 & 3.07 & 166.3 & 2.5 & 159.5 & 70.2 & 166.3 & 2.5 \\
\hline CSP3_19 & 570.1 & 0.79 & 38.565 & 1.50 & 0.0470 & 3.01 & 165.0 & 2.4 & 49.5 & 70.4 & 165.0 & 2.4 \\
\hline CSP3_18 & 404.5 & 0.79 & 38.665 & 1.20 & 0.0485 & 1.51 & 164.6 & 1.9 & 125.9 & 35.2 & 164.6 & 1.9 \\
\hline CSP3_17 & 477.5 & 0.95 & 39.712 & 1.19 & 0.0493 & 1.54 & 160.3 & 1.9 & 160.4 & 35.6 & 160.3 & 1.9 \\
\hline CSP3_16 & 613.9 & 0.54 & 38.586 & 1.18 & 0.0499 & 1.31 & 164.9 & 1.9 & 189.2 & 30.2 & 164.9 & 1.9 \\
\hline CSP3_15 & 590.7 & 1.04 & 39.335 & 1.24 & 0.0508 & 1.45 & 161.8 & 2.0 & 230.6 & 33.1 & 161.8 & 2.0 \\
\hline CSP3_14 & 441.1 & 0.82 & 39.566 & 1.23 & 0.0478 & 1.43 & 160.9 & 2.0 & 87.5 & 33.7 & 160.9 & 2.0 \\
\hline CSP3_13 & 322.6 & 0.83 & 45.938 & 1.92 & 0.0492 & 1.93 & 138.8 & 2.6 & 158.4 & 44.4 & 138.8 & 2.6 \\
\hline CSP3_12 & 289.0 & 0.74 & 39.953 & 1.03 & 0.0489 & 1.64 & 159.4 & 1.6 & 143.0 & 38.0 & 159.4 & 1.6 \\
\hline CSP3_11 & 355.9 & 0.79 & 39.119 & 0.89 & 0.0487 & 1.46 & 162.7 & 1.4 & 132.1 & 33.9 & 162.7 & 1.4 \\
\hline CSP3_10 & 277.4 & 0.58 & 38.399 & 0.99 & 0.0496 & 1.61 & 165.7 & 1.6 & 176.3 & 37.1 & 165.7 & 1.6 \\
\hline CSP3_9 & 369.4 & 0.89 & 38.179 & 1.01 & 0.0519 & 1.48 & 166.7 & 1.7 & 281.5 & 33.5 & 166.7 & 1.7 \\
\hline
\end{tabular}




\begin{tabular}{|c|c|c|c|c|c|c|c|c|c|c|c|c|}
\hline CSP3_8 & 391.7 & 0.73 & 38.486 & 0.93 & 0.0476 & 1.49 & 165.4 & 1.5 & 80.7 & 34.9 & 165.4 & 1.5 \\
\hline CSP3_7 & 325.9 & 0.61 & 41.748 & 1.13 & 0.0505 & 1.53 & 152.6 & 1.7 & 219.1 & 35.0 & 152.6 & 1.7 \\
\hline CSP3_6 & 1538.3 & 0.74 & 36.413 & 1.04 & 0.0535 & 0.88 & 174.6 & 1.8 & 350.0 & 19.7 & 174.6 & 1.8 \\
\hline CSP3_5 & 388.3 & 0.67 & 38.749 & 1.33 & 0.0489 & 1.89 & 164.3 & 2.2 & 144.0 & 43.7 & 164.3 & 2.2 \\
\hline CSP3_4 & 439.1 & 0.88 & 40.325 & 1.19 & 0.0489 & 1.32 & 157.9 & 1.9 & 144.4 & 30.7 & 157.9 & 1.9 \\
\hline CSP3_3 & 329.1 & 0.86 & 36.458 & 1.23 & 0.0567 & 1.94 & 174.4 & 2.1 & 481.7 & 42.4 & 174.4 & 2.1 \\
\hline CSP3_2 & 454.3 & 0.74 & 37.566 & 1.57 & 0.0639 & 3.81 & 169.4 & 2.6 & 737.5 & 78.6 & 169.4 & 2.6 \\
\hline \multicolumn{13}{|c|}{ CSP 5} \\
\hline CSP5_33 & 505.8 & 0.76 & 38.907 & 2.06 & 0.0503 & 2.02 & 163.6 & 3.3 & 209.1 & 46.1 & 163.6 & 3.3 \\
\hline CSP5_32 & 469.5 & 0.66 & 37.985 & 2.07 & 0.0501 & 1.92 & 167.5 & 3.4 & 197.9 & 44.0 & 167.5 & 3.4 \\
\hline CSP5_31 & 659.1 & 0.68 & 37.657 & 1.88 & 0.0495 & 1.42 & 169.0 & 3.1 & 172.0 & 32.9 & 169.0 & 3.1 \\
\hline CSP5_30 & 406.6 & 0.64 & 37.315 & 1.91 & 0.0512 & 1.69 & 170.5 & 3.2 & 249.9 & 38.4 & 170.5 & 3.2 \\
\hline CSP5_29 & 806.6 & 0.56 & 39.070 & 1.92 & 0.0505 & 1.49 & 162.9 & 3.1 & 217.6 & 34.2 & 162.9 & 3.1 \\
\hline CSP5_27 & 332.4 & 0.51 & 40.220 & 2.08 & 0.0511 & 1.81 & 158.3 & 3.3 & 246.1 & 41.2 & 158.3 & 3.3 \\
\hline CSP5_26 & 464.8 & 0.44 & 39.332 & 2.46 & 0.0492 & 2.64 & 161.8 & 3.9 & 159.3 & 60.7 & 161.8 & 3.9 \\
\hline CSP5_24 & 261.6 & 0.73 & 39.041 & 2.17 & 0.0503 & 1.62 & 163.0 & 3.5 & 208.5 & 37.2 & 163.0 & 3.5 \\
\hline CSP5_23 & 427.0 & 0.55 & 39.264 & 2.23 & 0.0504 & 2.24 & 162.1 & 3.6 & 213.3 & 51.1 & 162.1 & 3.6 \\
\hline CSP5_22 & 710.9 & 0.58 & 38.715 & 2.10 & 0.0480 & 1.24 & 164.4 & 3.4 & 97.3 & 29.0 & 164.4 & 3.4 \\
\hline CSP5_21 & 1000.6 & 0.70 & 39.557 & 2.06 & 0.0498 & 1.19 & 160.9 & 3.3 & 184.0 & 27.4 & 160.9 & 3.3 \\
\hline CSP5_20 & 347.6 & 0.48 & 38.966 & 2.60 & 0.0535 & 1.87 & 163.4 & 4.2 & 350.8 & 41.8 & 163.4 & 4.2 \\
\hline CSP5_19 & 896.0 & 0.77 & 38.087 & 2.12 & 0.0490 & 2.14 & 167.1 & 3.5 & 147.5 & 49.5 & 167.1 & 3.5 \\
\hline CSP5_18 & 696.7 & 0.56 & 38.523 & 1.96 & 0.0493 & 1.91 & 165.2 & 3.2 & 160.5 & 44.1 & 165.2 & 3.2 \\
\hline CSP5_17 & 495.6 & 0.72 & 38.608 & 2.01 & 0.0500 & 2.06 & 164.8 & 3.3 & 196.7 & 47.2 & 164.8 & 3.3 \\
\hline CSP5_16 & 765.0 & 0.57 & 38.097 & 1.98 & 0.0497 & 1.87 & 167.0 & 3.3 & 180.1 & 42.9 & 167.0 & 3.3 \\
\hline CSP5_15 & 849.5 & 0.72 & 38.293 & 2.02 & 0.0488 & 1.92 & 166.2 & 3.3 & 136.2 & 44.5 & 166.2 & 3.3 \\
\hline CSP5_14 & 713.3 & 0.58 & 38.792 & 2.10 & 0.0491 & 2.05 & 164.1 & 3.4 & 151.2 & 47.2 & 164.1 & 3.4 \\
\hline CSP5_12 & 715.3 & 0.50 & 38.957 & 1.94 & 0.0487 & 2.38 & 163.4 & 3.1 & 131.8 & 55.0 & 163.4 & 3.1 \\
\hline CSP5_11 & 659.9 & 0.48 & 39.022 & 1.73 & 0.0496 & 2.01 & 163.1 & 2.8 & 178.3 & 46.2 & 163.1 & 2.8 \\
\hline CSP5_10 & 506.9 & 0.74 & 39.150 & 1.60 & 0.0489 & 2.00 & 162.6 & 2.6 & 141.5 & 46.2 & 162.6 & 2.6 \\
\hline CSP5_9 & 755.0 & 0.56 & 38.903 & 1.92 & 0.0483 & 2.04 & 163.6 & 3.1 & 112.5 & 47.5 & 163.6 & 3.1 \\
\hline
\end{tabular}




\begin{tabular}{|c|c|c|c|c|c|c|c|c|c|c|c|c|}
\hline CSP5_8 & 540.3 & 0.60 & 41.710 & 1.89 & 0.0499 & 2.94 & 152.7 & 2.9 & 192.5 & 67.1 & 152.7 & 2.9 \\
\hline CSP5_7 & 841.3 & 0.53 & 39.305 & 1.76 & 0.0504 & 2.23 & 162.0 & 2.8 & 212.5 & 50.8 & 162.0 & 2.8 \\
\hline CSP5_6 & 370.1 & 0.69 & 38.642 & 1.72 & 0.0481 & 1.65 & 164.7 & 2.8 & 105.5 & 38.4 & 164.7 & 2.8 \\
\hline CSP5_5 & 398.2 & 0.55 & 38.197 & 1.72 & 0.0498 & 1.62 & 166.6 & 2.8 & 185.4 & 37.2 & 166.6 & 2.8 \\
\hline CSP5_4 & 211.5 & 0.71 & 38.059 & 1.82 & 0.0495 & 2.06 & 167.2 & 3.0 & 169.4 & 47.3 & 167.2 & 3.0 \\
\hline CSP5_3 & 445.0 & 0.55 & 37.479 & 1.75 & 0.0489 & 1.61 & 169.7 & 2.9 & 143.5 & 37.5 & 169.7 & 2.9 \\
\hline CSP5_1 & 419.5 & 0.55 & 37.307 & 2.01 & 0.0523 & 1.79 & 170.5 & 3.4 & 296.9 & 40.3 & 170.5 & 3.4 \\
\hline \multicolumn{13}{|c|}{ Ibagué batholith } \\
\hline \multicolumn{13}{|c|}{ CI15 } \\
\hline CI15_22 & 2137.0 & 0.54 & 42.434 & 1.73 & 0.0489 & 0.81 & 150.2 & 2.6 & 145.1 & 18.9 & 150.2 & 2.6 \\
\hline CI15_21 & 516.4 & 0.51 & 43.469 & 1.69 & 0.0482 & 1.28 & 146.6 & 2.4 & 107.4 & 29.9 & 146.6 & 2.4 \\
\hline CI15_20 & 148.0 & 0.75 & 44.041 & 2.10 & 0.0478 & 2.04 & 144.7 & 3.0 & 88.2 & 47.6 & 144.7 & 3.0 \\
\hline CI15_19 & 161.1 & 0.64 & 42.879 & 2.23 & 0.0467 & 2.19 & 148.6 & 3.3 & 35.0 & 51.4 & 148.6 & 3.3 \\
\hline CI15_18 & 155.1 & 0.63 & 44.831 & 1.95 & 0.0513 & 1.94 & 142.2 & 2.7 & 254.7 & 44.1 & 142.2 & 2.7 \\
\hline CI15_16 & 115.7 & 0.67 & 42.894 & 2.02 & 0.0502 & 2.28 & 148.6 & 3.0 & 205.4 & 52.0 & 148.6 & 3.0 \\
\hline CI15_15 & 302.0 & 0.52 & 43.544 & 1.80 & 0.0491 & 1.68 & 146.4 & 2.6 & 154.7 & 38.9 & 146.4 & 2.6 \\
\hline CI15_14 & 167.7 & 0.95 & 43.931 & 2.03 & 0.0486 & 1.85 & 145.1 & 2.9 & 126.4 & 43.0 & 145.1 & 2.9 \\
\hline CI15_12 & 166.0 & 0.70 & 44.583 & 2.01 & 0.0504 & 2.07 & 143.0 & 2.8 & 211.4 & 47.2 & 143.0 & 2.8 \\
\hline CI15_11 & 221.8 & 0.69 & 43.742 & 1.96 & 0.0504 & 1.64 & 145.7 & 2.8 & 213.3 & 37.6 & 145.7 & 2.8 \\
\hline CI15_10 & 188.7 & 0.55 & 43.524 & 2.25 & 0.0465 & 1.88 & 146.4 & 3.3 & 22.5 & 44.8 & 146.4 & 3.3 \\
\hline CI15_9 & 357.2 & 0.71 & 43.676 & 2.08 & 0.0471 & 1.32 & 145.9 & 3.0 & 52.1 & 31.3 & 145.9 & 3.0 \\
\hline CI15_8 & 153.4 & 0.87 & 43.408 & 2.16 & 0.0483 & 2.22 & 146.8 & 3.1 & 115.1 & 51.6 & 146.8 & 3.1 \\
\hline CI15_6 & 84.0 & 0.65 & 44.959 & 2.30 & 0.0436 & 2.97 & 141.8 & 3.2 & 0.0 & 0.0 & 141.8 & 3.2 \\
\hline CI15_5 & 301.9 & 0.60 & 44.393 & 1.92 & 0.0488 & 1.53 & 143.6 & 2.7 & 136.5 & 35.6 & 143.6 & 2.7 \\
\hline CI15_4 & 166.8 & 0.64 & 45.806 & 2.19 & 0.0487 & 2.11 & 139.2 & 3.0 & 132.0 & 48.9 & 139.2 & 3.0 \\
\hline CI15_3 & 164.5 & 0.99 & 43.540 & 2.93 & 0.0491 & 2.47 & 146.4 & 4.2 & 150.6 & 56.9 & 146.4 & 4.2 \\
\hline CI15_2 & 173.4 & 0.61 & 44.176 & 2.03 & 0.0502 & 1.85 & 144.3 & 2.9 & 204.7 & 42.4 & 144.3 & 2.9 \\
\hline CI15_1 & 190.4 & 0.72 & 44.029 & 2.22 & 0.0457 & 2.05 & 144.8 & 3.2 & 0.0 & 29.3 & 144.8 & 3.2 \\
\hline \multicolumn{13}{|c|}{ CI13 } \\
\hline CI13_36 & 108.3 & 0.80 & 44.441 & 2.66 & 0.0502 & 2.43 & 143.4 & 3.8 & 204.8 & 55.3 & 143.4 & 3.8 \\
\hline
\end{tabular}




\begin{tabular}{|c|c|c|c|c|c|c|c|c|c|c|c|c|}
\hline CI13_35 & 146.8 & 0.65 & 44.772 & 2.39 & 0.0504 & 2.02 & 142.4 & 3.4 & 212.2 & 46.2 & 142.4 & 3.4 \\
\hline CI13_34 & 509.4 & 0.30 & 45.159 & 2.36 & 0.0486 & 1.64 & 141.2 & 3.3 & 129.7 & 38.1 & 141.2 & 3.3 \\
\hline CI13_33 & 141.0 & 0.61 & 44.935 & 2.47 & 0.0500 & 2.81 & 141.9 & 3.5 & 193.4 & 64.0 & 141.9 & 3.5 \\
\hline CI13_31 & 217.2 & 0.98 & 45.343 & 2.43 & 0.0498 & 2.17 & 140.6 & 3.4 & 186.3 & 49.9 & 140.6 & 3.4 \\
\hline CI13_30 & 119.1 & 0.68 & 44.465 & 2.52 & 0.0508 & 2.13 & 143.4 & 3.6 & 230.0 & 48.5 & 143.4 & 3.6 \\
\hline CI13_29 & 122.2 & 0.67 & 44.365 & 2.39 & 0.0475 & 2.18 & 143.7 & 3.4 & 72.9 & 51.0 & 143.7 & 3.4 \\
\hline CI13_28 & 118.7 & 0.67 & 45.714 & 2.40 & 0.0451 & 2.62 & 139.5 & 3.3 & 0.0 & 6.7 & 139.5 & 3.3 \\
\hline CI13_27 & 147.6 & 0.75 & 44.810 & 2.57 & 0.0473 & 2.26 & 142.3 & 3.6 & 62.6 & 52.9 & 142.3 & 3.6 \\
\hline CI13_24 & 164.3 & 0.52 & 44.695 & 2.48 & 0.0491 & 2.16 & 142.6 & 3.5 & 154.6 & 49.7 & 142.6 & 3.5 \\
\hline CI13_22 & 164.6 & 0.50 & 43.831 & 2.57 & 0.0512 & 2.30 & 145.4 & 3.7 & 249.0 & 52.1 & 145.4 & 3.7 \\
\hline CI13_21 & 109.8 & 0.67 & 45.606 & 2.47 & 0.0524 & 2.27 & 139.8 & 3.4 & 301.7 & 50.9 & 139.8 & 3.4 \\
\hline CI13_20 & 123.8 & 0.66 & 43.379 & 2.48 & 0.0475 & 2.99 & 146.9 & 3.6 & 74.8 & 69.6 & 146.9 & 3.6 \\
\hline CI13_19 & 126.6 & 0.65 & 44.161 & 1.84 & 0.0465 & 2.38 & 144.3 & 2.6 & 23.2 & 56.1 & 144.3 & 2.6 \\
\hline CI13_18 & 241.7 & 0.69 & 45.458 & 2.85 & 0.0478 & 3.67 & 140.3 & 3.9 & 91.8 & 84.6 & 140.3 & 3.9 \\
\hline CI13_17 & 126.6 & 0.66 & 43.928 & 1.82 & 0.0468 & 2.33 & 145.1 & 2.6 & 41.1 & 54.9 & 145.1 & 2.6 \\
\hline CI13_14 & 117.8 & 0.63 & 44.705 & 1.83 & 0.0501 & 2.46 & 142.6 & 2.6 & 199.2 & 56.1 & 142.6 & 2.6 \\
\hline CI13_11 & 234.0 & 0.82 & 43.542 & 1.80 & 0.0480 & 1.75 & 146.4 & 2.6 & 99.5 & 40.8 & 146.4 & 2.6 \\
\hline CI13_9 & 167.9 & 0.61 & 44.794 & 1.54 & 0.0491 & 2.95 & 142.3 & 2.2 & 152.4 & 67.7 & 142.3 & 2.2 \\
\hline CI13_8 & 211.8 & 0.60 & 44.122 & 1.56 & 0.0480 & 2.75 & 144.5 & 2.2 & 101.0 & 63.8 & 144.5 & 2.2 \\
\hline CI13_7 & 216.0 & 0.96 & 43.849 & 1.35 & 0.0493 & 2.64 & 145.4 & 1.9 & 163.3 & 60.5 & 145.4 & 1.9 \\
\hline CI13_6 & 145.2 & 0.67 & 45.099 & 1.60 & 0.0485 & 2.94 & 141.4 & 2.2 & 124.6 & 67.8 & 141.4 & 2.2 \\
\hline CI13_5 & 166.2 & 0.68 & 43.263 & 1.43 & 0.0479 & 2.85 & 147.3 & 2.1 & 94.6 & 66.1 & 147.3 & 2.1 \\
\hline CI13_4 & 402.3 & 1.07 & 44.321 & 1.32 & 0.0490 & 2.45 & 143.8 & 1.9 & 145.6 & 56.6 & 143.8 & 1.9 \\
\hline CI13_3 & 119.0 & 0.76 & 45.023 & 1.62 & 0.0503 & 2.92 & 141.6 & 2.3 & 210.6 & 66.3 & 141.6 & 2.3 \\
\hline CI13_2 & 106.8 & 0.65 & 43.176 & 1.63 & 0.0464 & 3.07 & 147.6 & 2.4 & 17.5 & 71.4 & 147.6 & 2.4 \\
\hline CI13_1 & 186.3 & 0.77 & 43.782 & 1.55 & 0.0473 & 2.77 & 145.6 & 2.2 & 65.7 & 64.8 & 145.6 & 2.2 \\
\hline \multicolumn{13}{|c|}{ CI11 } \\
\hline CI11_30 & 257.9 & 0.56 & 42.693 & 1.28 & 0.0485 & 2.48 & 149.3 & 1.9 & 123.1 & 57.4 & 149.3 & 1.9 \\
\hline CI11_29 & 269.6 & 0.82 & 41.304 & 1.25 & 0.0498 & 2.80 & 154.2 & 1.9 & 184.2 & 63.9 & 154.2 & 1.9 \\
\hline CI11_28 & 181.0 & 0.82 & 42.691 & 1.34 & 0.0482 & 2.62 & 149.3 & 2.0 & 109.3 & 60.8 & 149.3 & 2.0 \\
\hline
\end{tabular}




\begin{tabular}{|c|c|c|c|c|c|c|c|c|c|c|c|}
\hline CI11_27 & 141.9 & 0.78 & 41.246 & 1.36 & 0.0475 & 2.82 & 154.4 & 2.1 & 72.6 & 65.8 & 154.4 \\
\hline CI11_26 & 197.3 & 0.95 & 42.669 & 1.24 & 0.0489 & 2.53 & 149.3 & 1.8 & 143.9 & 58.4 & 149.3 \\
\hline CI11_25 & 180.0 & 0.89 & 42.708 & 1.37 & 0.0481 & 2.84 & 149.2 & 2.0 & 103.9 & 65.7 & 149.2 \\
\hline CI11_24 & 197.3 & 1.04 & 41.611 & 1.19 & 0.0490 & 2.51 & 153.1 & 1.8 & 148.2 & 57.9 & 153.1 \\
\hline CI11_23 & 268.6 & 0.82 & 43.961 & 1.15 & 0.0468 & 2.49 & 145.0 & 1.7 & 36.4 & 58.8 & 145.0 \\
\hline CI11_22 & 506.3 & 0.55 & 41.979 & 1.02 & 0.0503 & 2.30 & 151.8 & 1.5 & 208.8 & 52.4 & 151.8 \\
\hline CI11_21 & 216.8 & 1.00 & 40.669 & 1.25 & 0.0482 & 2.62 & 156.6 & 1.9 & 111.5 & 60.7 & 156.6 \\
\hline CI11_20 & 219.1 & 0.55 & 42.004 & 1.18 & 0.0478 & 2.58 & 151.7 & 1.8 & 87.2 & 60.0 & 151.7 \\
\hline CI11_19 & 312.6 & 0.87 & 41.905 & 1.08 & 0.0508 & 2.56 & 152.0 & 1.6 & 233.4 & 58.0 & 152.0 \\
\hline CI11_18 & 237.7 & 0.97 & 41.937 & 1.14 & 0.0499 & 2.70 & 151.9 & 1.7 & 188.8 & 61.6 & 151.9 \\
\hline CI11_17 & 156.8 & 0.89 & 41.463 & 1.34 & 0.0507 & 2.89 & 153.6 & 2.0 & 226.1 & 65.4 & 153.6 \\
\hline CI11_16 & 209.0 & 1.02 & 41.948 & 1.25 & 0.0466 & 2.72 & 151.9 & 1.9 & 28.2 & 64.1 & 151.9 \\
\hline CI11_15 & 116.1 & 0.65 & 42.220 & 1.46 & 0.0490 & 3.07 & 150.9 & 2.2 & 147.2 & 70.4 & 150.9 \\
\hline CI11_14 & 233.6 & 1.01 & 42.236 & 1.24 & 0.0480 & 2.72 & 150.9 & 1.8 & 97.9 & 63.2 & 150.9 \\
\hline CI11_13 & 202.7 & 0.67 & 41.808 & 1.24 & 0.0475 & 2.76 & 152.4 & 1.9 & 72.6 & 64.3 & 152.4 \\
\hline CI11_12 & 256.8 & 0.92 & 41.743 & 1.84 & 0.0488 & 2.19 & 152.6 & 2.8 & 140.6 & 50.7 & 152.6 \\
\hline CI11_11 & 182.1 & 0.80 & 42.683 & 1.90 & 0.0489 & 2.30 & 149.3 & 2.8 & 140.7 & 53.1 & 149.3 \\
\hline CI11_10 & 296.3 & 0.94 & 40.677 & 1.81 & 0.0500 & 2.18 & 156.6 & 2.8 & 196.6 & 50.0 & 156.6 \\
\hline CI11_9 & 215.0 & 1.00 & 41.893 & 1.94 & 0.0503 & 2.35 & 152.1 & 2.9 & 210.1 & 53.5 & 152.1 \\
\hline CI11_8 & 278.8 & 0.82 & 41.241 & 1.90 & 0.0489 & 2.24 & 154.4 & 2.9 & 143.1 & 51.6 & 154.4 \\
\hline CI11_7 & 464.9 & 0.73 & 39.369 & 1.78 & 0.0493 & 2.02 & 161.7 & 2.8 & 162.8 & 46.6 & 161.7 \\
\hline CI11_6 & 213.2 & 0.69 & 41.360 & 2.40 & 0.0476 & 2.88 & 154.0 & 3.7 & 80.5 & 66.9 & 154.0 \\
\hline CI11_5 & 294.0 & 0.88 & 41.244 & 2.37 & 0.0479 & 2.81 & 154.4 & 3.6 & 93.6 & 65.2 & 154.4 \\
\hline CI11_4 & 189.6 & 0.92 & 40.897 & 2.34 & 0.0481 & 2.98 & 155.7 & 3.6 & 105.7 & 68.9 & 155.7 \\
\hline CI11_3 & 319.8 & 0.86 & 41.163 & 2.42 & 0.0465 & 2.76 & 154.7 & 3.7 & 22.0 & 65.9 & 154.7 \\
\hline CI11_2 & 491.0 & 0.52 & 41.160 & 2.26 & 0.0489 & 2.71 & 154.7 & 3.5 & 141.9 & 62.4 & 154.7 \\
\hline CI11_1 & 307.1 & 0.70 & 40.833 & 2.20 & 0.0475 & 2.91 & 156.0 & 3.4 & 73.9 & 67.7 & 156.0 \\
\hline \multicolumn{12}{|c|}{ CI12 } \\
\hline CI2_30 & 109.5 & 0.65 & 44.394 & 2.50 & 0.0489 & 3.20 & 143.6 & 3.5 & 143.3 & 73.4 & 143.6 \\
\hline CI2_29 & 117.9 & 0.79 & 44.618 & 2.50 & 0.0493 & 3.19 & 142.9 & 3.5 & 162.9 & 73.0 & 142.9 \\
\hline
\end{tabular}




\begin{tabular}{|c|c|c|c|c|c|c|c|c|c|c|c|c|}
\hline CI2_28 & 348.3 & 0.81 & 45.341 & 2.23 & 0.0489 & 2.73 & 140.6 & 3.1 & 145.3 & 62.8 & 140.6 & 3.1 \\
\hline CI2_27 & 1142.5 & 0.59 & 41.895 & 2.23 & 0.0476 & 2.48 & 152.1 & 3.3 & 80.3 & 57.7 & 152.1 & 3.3 \\
\hline CI2_26 & 379.2 & 0.54 & 43.879 & 2.25 & 0.0493 & 2.68 & 145.3 & 3.2 & 163.5 & 61.4 & 145.3 & 3.2 \\
\hline CI2_25 & 329.1 & 0.48 & 44.588 & 2.30 & 0.0484 & 2.65 & 143.0 & 3.3 & 120.7 & 61.3 & 143.0 & 3.3 \\
\hline CI2_24 & 461.8 & 0.74 & 44.450 & 2.19 & 0.0479 & 2.61 & 143.4 & 3.1 & 92.7 & 60.7 & 143.4 & 3.1 \\
\hline CI2_23 & 422.9 & 0.61 & 43.066 & 2.34 & 0.0481 & 2.63 & 148.0 & 3.4 & 102.8 & 61.1 & 148.0 & 3.4 \\
\hline CI2_22 & 434.8 & 0.71 & 46.142 & 2.39 & 0.0492 & 2.69 & 138.2 & 3.3 & 156.2 & 61.7 & 138.2 & 3.3 \\
\hline CI2_21 & 292.5 & 0.57 & 44.139 & 2.40 & 0.0563 & 2.90 & 144.4 & 3.4 & 464.1 & 63.0 & 144.4 & 3.4 \\
\hline CI2_20 & 384.8 & 0.52 & 43.990 & 1.92 & 0.0487 & 2.08 & 144.9 & 2.8 & 133.7 & 48.2 & 144.9 & 2.8 \\
\hline CI2_19 & 574.1 & 1.12 & 44.064 & 2.09 & 0.0480 & 1.97 & 144.7 & 3.0 & 97.5 & 46.0 & 144.7 & 3.0 \\
\hline CI2_18 & 293.5 & 0.92 & 45.918 & 2.07 & 0.0468 & 2.24 & 138.9 & 2.8 & 40.0 & 52.7 & 138.9 & 2.8 \\
\hline CI2_16 & 280.8 & 0.63 & 44.056 & 1.97 & 0.0495 & 2.22 & 144.7 & 2.8 & 171.1 & 51.0 & 144.7 & 2.8 \\
\hline CI2_15 & 667.6 & 1.08 & 43.708 & 1.92 & 0.0479 & 1.95 & 145.8 & 2.8 & 95.2 & 45.5 & 145.8 & 2.8 \\
\hline CI2_14 & 318.8 & 0.55 & 44.610 & 2.09 & 0.0480 & 2.10 & 142.9 & 3.0 & 99.9 & 49.0 & 142.9 & 3.0 \\
\hline CI2_12 & 161.1 & 0.67 & 45.691 & 2.05 & 0.0471 & 2.57 & 139.6 & 2.8 & 52.3 & 60.2 & 139.6 & 2.8 \\
\hline CI2_10 & 779.0 & 0.91 & 44.418 & 2.10 & 0.0476 & 1.87 & 143.5 & 3.0 & 79.3 & 43.7 & 143.5 & 3.0 \\
\hline CI2_9 & 401.7 & 0.63 & 45.620 & 1.46 & 0.0490 & 1.90 & 139.8 & 2.0 & 147.5 & 43.9 & 139.8 & 2.0 \\
\hline CI2_8 & 343.8 & 0.73 & 44.922 & 1.48 & 0.0490 & 1.93 & 141.9 & 2.1 & 148.3 & 44.6 & 141.9 & 2.1 \\
\hline CI2_6 & 130.2 & 0.48 & 43.001 & 1.80 & 0.0462 & 2.50 & 148.2 & 2.6 & 8.9 & 57.6 & 148.2 & 2.6 \\
\hline CI2_5 & 410.4 & 0.58 & 42.994 & 1.36 & 0.0484 & 1.87 & 148.2 & 2.0 & 119.3 & 43.6 & 148.2 & 2.0 \\
\hline CI2_4 & 345.5 & 0.63 & 44.576 & 1.38 & 0.0491 & 1.92 & 143.0 & 2.0 & 153.9 & 44.3 & 143.0 & 2.0 \\
\hline \multicolumn{13}{|c|}{ CI9B } \\
\hline CI9B_31 & 130.9 & 1.00 & 44.196 & 1.46 & 0.0472 & 1.70 & 144.2 & 2.1 & 58.7 & 40.1 & 144.2 & 2.1 \\
\hline CI9B_30 & 119.8 & 0.90 & 44.938 & 1.51 & 0.0475 & 1.92 & 141.9 & 2.1 & 74.9 & 45.1 & 141.9 & 2.1 \\
\hline CI9B_29 & 94.3 & 0.85 & 45.812 & 1.61 & 0.0487 & 2.01 & 139.2 & 2.2 & 135.6 & 46.5 & 139.2 & 2.2 \\
\hline CI9B_28 & 69.3 & 0.67 & 46.275 & 1.87 & 0.0535 & 2.51 & 137.8 & 2.6 & 351.9 & 55.7 & 137.8 & 2.6 \\
\hline CI9B_27 & 99.2 & 0.74 & 44.826 & 1.45 & 0.0498 & 2.05 & 142.2 & 2.0 & 185.7 & 47.0 & 142.2 & 2.0 \\
\hline CI9B_26 & 119.6 & 0.91 & 44.539 & 1.59 & 0.0497 & 1.77 & 143.1 & 2.3 & 179.9 & 40.6 & 143.1 & 2.3 \\
\hline CI9B_25 & 116.6 & 0.92 & 45.320 & 1.49 & 0.0502 & 2.00 & 140.7 & 2.1 & 204.1 & 45.7 & 140.7 & 2.1 \\
\hline CI9B_23 & 168.7 & 0.91 & 44.927 & 1.55 & 0.0487 & 1.57 & 141.9 & 2.2 & 135.2 & 36.4 & 141.9 & 2.2 \\
\hline
\end{tabular}




\begin{tabular}{|c|c|c|c|c|c|c|c|c|c|c|c|c|}
\hline CI9B_22 & 117.8 & 0.75 & 45.153 & 1.51 & 0.0509 & 1.83 & 141.2 & 2.1 & 238.3 & 41.8 & 141.2 & 2.1 \\
\hline CI9B_20 & 169.8 & 0.92 & 46.433 & 1.45 & 0.0485 & 1.52 & 137.4 & 2.0 & 122.9 & 35.4 & 137.4 & 2.0 \\
\hline CI9B_19 & 138.5 & 0.60 & 45.050 & 1.77 & 0.0494 & 1.95 & 141.5 & 2.5 & 164.7 & 45.0 & 141.5 & 2.5 \\
\hline CI9B_18 & 160.2 & 0.97 & 45.464 & 1.55 & 0.0488 & 1.69 & 140.3 & 2.1 & 136.1 & 39.3 & 140.3 & 2.1 \\
\hline CI9B_17 & 101.8 & 0.76 & 44.177 & 1.74 & 0.0489 & 1.90 & 144.3 & 2.5 & 145.3 & 44.0 & 144.3 & 2.5 \\
\hline CI9B_16 & 119.7 & 0.80 & 45.912 & 1.59 & 0.0498 & 1.80 & 138.9 & 2.2 & 183.5 & 41.5 & 138.9 & 2.2 \\
\hline CI9B_15 & 137.4 & 0.47 & 44.322 & 1.57 & 0.0486 & 1.79 & 143.8 & 2.2 & 129.8 & 41.5 & 143.8 & 2.2 \\
\hline CI9B_14 & 172.9 & 0.96 & 44.535 & 1.31 & 0.0488 & 1.63 & 143.1 & 1.9 & 136.2 & 37.8 & 143.1 & 1.9 \\
\hline CI9B_13 & 140.3 & 0.81 & 44.105 & 1.61 & 0.0475 & 1.67 & 144.5 & 2.3 & 75.1 & 39.2 & 144.5 & 2.3 \\
\hline CI9B_12 & 126.1 & 0.96 & 44.802 & 2.15 & 0.0486 & 1.73 & 142.3 & 3.0 & 126.8 & 40.2 & 142.3 & 3.0 \\
\hline CI9B_11 & 144.8 & 0.88 & 44.882 & 2.06 & 0.0500 & 1.63 & 142.1 & 2.9 & 197.2 & 37.4 & 142.1 & 2.9 \\
\hline CI9B_10 & 107.8 & 0.70 & 44.935 & 2.18 & 0.0504 & 1.79 & 141.9 & 3.1 & 211.7 & 41.0 & 141.9 & 3.1 \\
\hline CI9B_9 & 123.8 & 0.92 & 45.692 & 2.33 & 0.0506 & 2.33 & 139.6 & 3.2 & 224.7 & 52.9 & 139.6 & 3.2 \\
\hline CI9B_8 & 128.5 & 0.93 & 45.387 & 2.04 & 0.0478 & 1.67 & 140.5 & 2.8 & 90.9 & 39.1 & 140.5 & 2.8 \\
\hline CI9B_7 & 99.2 & 0.63 & 44.872 & 2.13 & 0.0497 & 2.02 & 142.1 & 3.0 & 182.8 & 46.5 & 142.1 & 3.0 \\
\hline CI9B_6 & 126.6 & 0.97 & 44.445 & 1.92 & 0.0484 & 1.71 & 143.4 & 2.7 & 118.3 & 39.8 & 143.4 & 2.7 \\
\hline CI9B_5 & 123.2 & 0.91 & 44.030 & 1.90 & 0.0513 & 1.83 & 144.8 & 2.7 & 255.6 & 41.5 & 144.8 & 2.7 \\
\hline CI9B_4 & 92.6 & 0.71 & 44.206 & 2.14 & 0.0498 & 2.31 & 144.2 & 3.0 & 186.3 & 52.9 & 144.2 & 3.0 \\
\hline CI9B_3 & 100.7 & 0.71 & 44.355 & 2.10 & 0.0496 & 2.06 & 143.7 & 3.0 & 177.2 & 47.3 & 143.7 & 3.0 \\
\hline CI9B_2 & 103.9 & 0.63 & 45.824 & 2.21 & 0.0478 & 2.21 & 139.2 & 3.0 & 87.9 & 51.5 & 139.2 & 3.0 \\
\hline CI9B_1 & 119.0 & 0.63 & 44.860 & 2.06 & 0.0461 & 2.19 & 142.1 & 2.9 & 1.8 & 50.6 & 142.1 & 2.9 \\
\hline \multicolumn{13}{|c|}{ GCC6 } \\
\hline GCC6-1 & 192.9 & 0.57 & 40.433 & 0.02 & 0.0476 & 0.05 & 157.5 & 3.0 & 77.9 & 113.2 & 157.5 & 3.0 \\
\hline GCC6-2 & 166.5 & 0.60 & 39.691 & 0.01 & 0.0474 & 0.09 & 160.4 & 1.1 & 69.1 & 202.6 & 160.4 & 1.1 \\
\hline GCC6-3 & 131.1 & 0.43 & 40.184 & 0.01 & 0.0488 & 0.09 & 158.5 & 0.8 & 138.7 & 200.8 & 158.5 & 0.8 \\
\hline GCC6-4 & 132.6 & 0.45 & 39.480 & 0.01 & 0.0490 & 0.06 & 161.2 & 1.8 & 147.5 & 133.9 & 161.2 & 1.8 \\
\hline GCC6-5 & 282.1 & 1.22 & 40.299 & 0.01 & 0.0492 & 0.06 & 158.0 & 1.4 & 158.9 & 130.0 & 158.0 & 1.4 \\
\hline GCC6-6 & 234.7 & 0.38 & 40.319 & 0.02 & 0.0484 & 0.03 & 157.9 & 2.4 & 117.8 & 69.3 & 157.9 & 2.4 \\
\hline GCC6-7 & 468.8 & 0.69 & 40.264 & 0.02 & 0.0506 & 0.01 & 158.1 & 3.2 & 222.6 & 33.5 & 158.1 & 3.2 \\
\hline GCC6-8 & 219.6 & 0.48 & 40.349 & 0.01 & 0.0483 & 0.03 & 157.8 & 0.8 & 116.4 & 64.8 & 157.8 & 0.8 \\
\hline
\end{tabular}




\begin{tabular}{|c|c|c|c|c|c|c|c|c|c|c|c|c|}
\hline GCC6-9 & 165.4 & 0.44 & 40.946 & 0.03 & 0.0486 & 0.04 & 155.5 & 5.2 & 128.6 & 102.9 & 155.5 & 5.2 \\
\hline GCC6-10 & 119.6 & 0.43 & 39.957 & 0.02 & 0.0449 & 0.10 & 159.3 & 3.0 & -59.9 & 232.4 & 159.3 & 3.0 \\
\hline GCC6-11 & 187.4 & 0.54 & 40.094 & 0.03 & 0.0466 & 0.06 & 158.8 & 4.4 & 26.6 & 139.8 & 158.8 & 4.4 \\
\hline GCC6-12 & 214.3 & 0.62 & 40.406 & 0.01 & 0.0463 & 0.06 & 157.6 & 2.2 & 12.3 & 148.7 & 157.6 & 2.2 \\
\hline GCC6-13 & 242.5 & 0.40 & 39.716 & 0.01 & 0.0477 & 0.03 & 160.3 & 1.1 & 82.9 & 82.6 & 160.3 & 1.1 \\
\hline GCC6-14 & 198.1 & 0.53 & 39.134 & 0.01 & 0.0490 & 0.05 & 162.7 & 2.0 & 146.8 & 117.8 & 162.7 & 2.0 \\
\hline GCC6-15 & 289.3 & 1.08 & 40.375 & 0.01 & 0.0495 & 0.07 & 157.7 & 1.2 & 169.9 & 162.2 & 157.7 & 1.2 \\
\hline GCC6-16 & 266.5 & 0.38 & 40.382 & 0.01 & 0.0477 & 0.04 & 157.7 & 0.8 & 84.1 & 99.1 & 157.7 & 0.8 \\
\hline GCC6-17 & 807.9 & 0.47 & 40.096 & 0.01 & 0.0535 & 0.03 & 158.8 & 1.6 & 351.4 & 61.0 & 158.8 & 1.6 \\
\hline GCC6-18 & 184.2 & 0.45 & 40.647 & 0.02 & 0.0500 & 0.17 & 156.7 & 2.5 & 194.4 & 408.6 & 156.7 & 2.5 \\
\hline GCC6-19 & 276.3 & 0.44 & 40.648 & 0.01 & 0.0486 & 0.03 & 156.7 & 0.8 & 128.4 & 80.5 & 156.7 & 0.8 \\
\hline GCC6-20 & 210.3 & 0.54 & 39.596 & 0.01 & 0.0478 & 0.04 & 160.8 & 0.8 & 88.2 & 99.2 & 160.8 & 0.8 \\
\hline GCC6-21 & 195.2 & 0.46 & 41.219 & 0.03 & 0.0586 & 0.11 & 154.5 & 3.9 & 553.3 & 249.1 & 154.5 & 3.9 \\
\hline GCC6-22 & 798.1 & 0.53 & 40.436 & 0.02 & 0.0531 & 0.17 & 157.5 & 2.6 & 334.7 & 376.4 & 157.5 & 2.6 \\
\hline GCC6-23 & 226.6 & 0.49 & 39.664 & 0.01 & 0.0473 & 0.04 & 160.5 & 0.8 & 63.4 & 106.2 & 160.5 & 0.8 \\
\hline GCC6-24 & 228.9 & 0.72 & 40.348 & 0.02 & 0.0480 & 0.06 & 157.8 & 2.6 & 97.0 & 135.0 & 157.8 & 2.6 \\
\hline GCC6-25 & 137.8 & 0.45 & 40.581 & 0.02 & 0.0474 & 0.05 & 156.9 & 3.1 & 69.8 & 117.7 & 156.9 & 3.1 \\
\hline GCC6-26 & 148.3 & 0.50 & 39.446 & 0.01 & 0.0471 & 0.07 & 161.4 & 2.1 & 55.5 & 161.0 & 161.4 & 2.1 \\
\hline GCC6-27 & 376.1 & 0.44 & 40.262 & 0.02 & 0.0489 & 0.02 & 158.2 & 3.5 & 143.9 & 43.0 & 158.2 & 3.5 \\
\hline GCC6-28 & 394.0 & 0.45 & 40.253 & 0.01 & 0.0481 & 0.03 & 158.2 & 0.9 & 101.9 & 68.3 & 158.2 & 0.9 \\
\hline GCC6-29 & 220.0 & 0.54 & 39.807 & 0.01 & 0.0476 & 0.04 & 159.9 & 1.3 & 81.6 & 95.3 & 159.9 & 1.3 \\
\hline GCC6-30 & 149.5 & 0.55 & 39.599 & 0.01 & 0.0457 & 0.09 & 160.8 & 1.6 & -15.9 & 206.3 & 160.8 & 1.6 \\
\hline GCC6-31 & 204.4 & 0.63 & 40.452 & 0.02 & 0.0473 & 0.05 & 157.4 & 2.8 & 64.1 & 111.4 & 157.4 & 2.8 \\
\hline GCC6-32 & 282.4 & 0.48 & 40.207 & 0.01 & 0.0492 & 0.04 & 158.4 & 1.7 & 157.6 & 83.8 & 158.4 & 1.7 \\
\hline GCC6-33 & 230.9 & 0.50 & 39.843 & 0.01 & 0.0492 & 0.02 & 159.8 & 0.8 & 156.9 & 54.5 & 159.8 & 0.8 \\
\hline GCC6-35 & 217.5 & 0.46 & 39.952 & 0.01 & 0.0519 & 0.08 & 159.4 & 1.2 & 283.0 & 187.7 & 159.4 & 1.2 \\
\hline GCC6-36 & 239.3 & 0.58 & 39.428 & 0.01 & 0.0610 & 0.15 & 161.5 & 0.8 & 639.0 & 333.6 & 161.5 & 0.8 \\
\hline GCC6-37 & 330.2 & 0.56 & 39.010 & 0.01 & 0.0476 & 0.04 & 163.2 & 0.9 & 77.8 & 105.0 & 163.2 & 0.9 \\
\hline GCC6-38 & 278.3 & 0.52 & 40.593 & 0.01 & 0.0484 & 0.04 & 156.9 & 1.1 & 121.1 & 82.7 & 156.9 & 1.1 \\
\hline GCC6-39 & 262.4 & 0.46 & 39.521 & 0.02 & 0.0481 & 0.05 & 161.1 & 3.7 & 103.4 & 107.8 & 161.1 & 3.7 \\
\hline
\end{tabular}




\begin{tabular}{|c|c|c|c|c|c|c|c|c|c|c|c|c|}
\hline GCC6-40 & 202.4 & 0.53 & 39.927 & 0.02 & 0.0486 & 0.03 & 159.5 & 3.0 & 129.4 & 66.0 & 159.5 & 3.0 \\
\hline GCC6-41 & 124.5 & 0.43 & 39.700 & 0.01 & 0.0481 & 0.18 & 160.4 & 1.9 & 105.8 & 427.2 & 160.4 & 1.9 \\
\hline GCC6-42 & 109.5 & 0.38 & 40.423 & 0.01 & 0.0573 & 0.30 & 157.5 & 1.7 & 503.2 & 681.4 & 157.5 & 1.7 \\
\hline GCC6-43 & 277.8 & 0.57 & 40.690 & 0.01 & 0.0486 & 0.03 & 156.5 & 1.4 & 129.9 & 75.4 & 156.5 & 1.4 \\
\hline GCC6-44 & 126.1 & 0.44 & 40.264 & 0.01 & 0.0543 & 0.07 & 158.1 & 1.8 & 383.6 & 168.0 & 158.1 & 1.8 \\
\hline GCC6-45 & 744.1 & 0.27 & 39.918 & 0.04 & 0.0500 & 0.01 & 159.5 & 5.9 & 195.1 & 33.6 & 159.5 & 5.9 \\
\hline GCC6-46 & 255.7 & 0.57 & 40.105 & 0.01 & 0.0512 & 0.04 & 158.8 & 0.8 & 248.1 & 98.1 & 158.8 & 0.8 \\
\hline GCC6-47 & 225.2 & 0.51 & 40.253 & 0.01 & 0.0481 & 0.04 & 158.2 & 1.3 & 103.7 & 92.8 & 158.2 & 1.3 \\
\hline GCC6-48 & 173.3 & 0.53 & 40.718 & 0.02 & 0.0457 & 0.08 & 156.4 & 2.9 & -17.7 & 190.0 & 156.4 & 2.9 \\
\hline \multicolumn{13}{|c|}{ Mariquita stock } \\
\hline \multicolumn{13}{|c|}{ CM7 } \\
\hline CM7_39 & 1957.9 & 0.37 & 48.706 & 1.13 & 0.0494 & 0.50 & 131.0 & 1.5 & 166.9 & 11.6 & 131.0 & 1.5 \\
\hline CM7_38 & 2484.4 & 0.42 & 49.231 & 1.06 & 0.0496 & 0.52 & 129.6 & 1.4 & 177.0 & 12.1 & 129.6 & 1.4 \\
\hline CM7_37 & 782.7 & 0.28 & 50.058 & 1.27 & 0.0496 & 0.92 & 127.5 & 1.6 & 178.0 & 21.3 & 127.5 & 1.6 \\
\hline CM7_36 & 775.9 & 0.33 & 49.316 & 1.21 & 0.0534 & 0.73 & 129.4 & 1.5 & 347.7 & 16.4 & 129.4 & 1.5 \\
\hline CM7_35 & 1686.0 & 0.37 & 49.751 & 1.27 & 0.0510 & 0.96 & 128.3 & 1.6 & 239.1 & 21.9 & 128.3 & 1.6 \\
\hline CM7_33 & 1346.3 & 0.51 & 46.985 & 1.02 & 0.0492 & 0.56 & 135.8 & 1.4 & 157.7 & 13.1 & 135.8 & 1.4 \\
\hline CM7_31 & 4194.0 & 0.48 & 48.222 & 1.01 & 0.0490 & 0.41 & 132.3 & 1.3 & 145.5 & 9.6 & 132.3 & 1.3 \\
\hline CM7_30 & 756.1 & 0.23 & 48.763 & 1.54 & 0.0491 & 0.84 & 130.9 & 2.0 & 154.9 & 19.5 & 130.9 & 2.0 \\
\hline CM7_27 & 442.2 & 0.38 & 49.371 & 1.71 & 0.0528 & 1.59 & 129.3 & 2.2 & 320.9 & 35.6 & 129.3 & 2.2 \\
\hline CM7_26 & 1751.1 & 0.40 & 49.997 & 2.21 & 0.0484 & 0.99 & 127.7 & 2.8 & 118.7 & 23.2 & 127.7 & 2.8 \\
\hline CM7_25 & 348.0 & 0.24 & 50.290 & 1.65 & 0.0498 & 1.17 & 126.9 & 2.1 & 184.7 & 27.1 & 126.9 & 2.1 \\
\hline CM7_24 & 4792.7 & 0.39 & 47.272 & 1.49 & 0.0506 & 0.60 & 134.9 & 2.0 & 221.1 & 13.8 & 134.9 & 2.0 \\
\hline CM7_21 & 600.8 & 0.34 & 49.267 & 1.60 & 0.0688 & 1.52 & 129.5 & 2.1 & 891.5 & 31.1 & 129.5 & 2.1 \\
\hline CM7_20 & 1440.7 & 0.46 & 49.163 & 1.42 & 0.0513 & 0.87 & 129.8 & 1.8 & 256.2 & 19.9 & 129.8 & 1.8 \\
\hline CM7_18 & 2040.7 & 0.40 & 48.678 & 1.49 & 0.0490 & 0.77 & 131.1 & 1.9 & 146.9 & 18.0 & 131.1 & 1.9 \\
\hline CM7_17 & 1761.8 & 0.36 & 49.091 & 1.63 & 0.0498 & 0.77 & 130.0 & 2.1 & 186.7 & 17.9 & 130.0 & 2.1 \\
\hline CM7_16 & 1729.2 & 0.32 & 49.069 & 1.50 & 0.0566 & 0.83 & 130.1 & 1.9 & 477.0 & 18.3 & 130.1 & 1.9 \\
\hline CM7_15 & 444.5 & 0.29 & 48.859 & 1.65 & 0.0476 & 1.15 & 130.6 & 2.1 & 81.4 & 27.1 & 130.6 & 2.1 \\
\hline CM7_14 & 1929.7 & 0.47 & 48.057 & 1.52 & 0.0505 & 0.80 & 132.8 & 2.0 & 217.0 & 18.5 & 132.8 & 2.0 \\
\hline
\end{tabular}




\begin{tabular}{|c|c|c|c|c|c|c|c|c|c|c|c|c|}
\hline CM7_13 & 1290.5 & 0.42 & 47.646 & 1.46 & 0.0494 & 0.87 & 133.9 & 1.9 & 167.0 & 20.2 & 133.9 & 1.9 \\
\hline CM7_12 & 1128.2 & 0.40 & 47.266 & 1.48 & 0.0489 & 0.86 & 135.0 & 2.0 & 142.3 & 19.9 & 135.0 & 2.0 \\
\hline CM7_11 & 404.5 & 0.26 & 48.386 & 1.38 & 0.0520 & 1.11 & 131.9 & 1.8 & 287.5 & 25.3 & 131.9 & 1.8 \\
\hline CM7_10 & 746.9 & 0.27 & 48.442 & 1.16 & 0.0509 & 0.93 & 131.7 & 1.5 & 237.2 & 21.3 & 131.7 & 1.5 \\
\hline CM7_9 & 595.7 & 0.28 & 49.424 & 1.26 & 0.0518 & 1.04 & 129.1 & 1.6 & 274.5 & 23.7 & 129.1 & 1.6 \\
\hline CM7_7 & 779.8 & 0.40 & 50.149 & 1.46 & 0.0501 & 1.29 & 127.3 & 1.8 & 200.1 & 29.7 & 127.3 & 1.8 \\
\hline CM7_6 & 1483.7 & 0.45 & 48.266 & 1.17 & 0.0492 & 0.80 & 132.2 & 1.5 & 158.9 & 18.6 & 132.2 & 1.5 \\
\hline CM7_4 & 702.0 & 0.25 & 49.817 & 1.29 & 0.0483 & 0.98 & 128.1 & 1.6 & 112.5 & 22.9 & 128.1 & 1.6 \\
\hline CM7_3 & 972.0 & 0.37 & 48.166 & 1.25 & 0.0492 & 0.87 & 132.5 & 1.6 & 157.1 & 20.1 & 132.5 & 1.6 \\
\hline CM7_2 & 828.8 & 0.33 & 48.621 & 1.27 & 0.0485 & 0.91 & 131.2 & 1.7 & 125.7 & 21.3 & 131.2 & 1.7 \\
\hline CM7_1 & 1127.2 & 0.33 & 49.361 & 1.08 & 0.0481 & 0.96 & 129.3 & 1.4 & 104.8 & 22.5 & 129.3 & 1.4 \\
\hline \multicolumn{13}{|c|}{ CM19 } \\
\hline CM19_39 & 2190.2 & 0.43 & 49.542 & 1.07 & 0.0502 & 0.78 & 128.8 & 1.4 & 205.3 & 17.9 & 128.8 & 1.4 \\
\hline CM19_38 & 985.5 & 0.40 & 48.167 & 1.10 & 0.0840 & 0.86 & 132.5 & 1.4 & 1293.1 & 16.7 & 132.5 & 1.4 \\
\hline CM19_37 & 299.8 & 0.36 & 49.735 & 1.35 & 0.0489 & 1.29 & 128.3 & 1.7 & 143.2 & 30.0 & 128.3 & 1.7 \\
\hline CM19_36 & 758.9 & 0.26 & 49.201 & 1.18 & 0.0493 & 1.14 & 129.7 & 1.5 & 162.9 & 26.5 & 129.7 & 1.5 \\
\hline CM19_35 & 1131.7 & 0.50 & 50.354 & 1.26 & 0.0496 & 0.97 & 126.8 & 1.6 & 175.1 & 22.4 & 126.8 & 1.6 \\
\hline CM19_34 & 800.4 & 0.46 & 49.010 & 1.01 & 0.0485 & 0.91 & 130.2 & 1.3 & 124.8 & 21.3 & 130.2 & 1.3 \\
\hline CM19_33 & 502.5 & 0.33 & 49.256 & 1.28 & 0.0512 & 1.22 & 129.6 & 1.6 & 251.3 & 27.9 & 129.6 & 1.6 \\
\hline CM19_31 & 1903.4 & 0.48 & 48.596 & 1.05 & 0.0500 & 0.74 & 131.3 & 1.4 & 196.6 & 17.1 & 131.3 & 1.4 \\
\hline CM19_30 & 937.9 & 0.33 & 47.994 & 1.18 & 0.0492 & 0.84 & 132.9 & 1.6 & 159.0 & 19.6 & 132.9 & 1.6 \\
\hline CM19_29 & 123.4 & 0.24 & 50.737 & 1.87 & 0.0540 & 2.15 & 125.8 & 2.3 & 370.5 & 47.6 & 125.8 & 2.3 \\
\hline CM19_28 & 498.0 & 0.33 & 49.100 & 1.45 & 0.0512 & 1.27 & 130.0 & 1.9 & 250.4 & 29.0 & 130.0 & 1.9 \\
\hline CM19_27 & 117.8 & 0.22 & 50.378 & 1.62 & 0.0492 & 1.98 & 126.7 & 2.0 & 155.5 & 45.7 & 126.7 & 2.0 \\
\hline CM19_26 & 728.4 & 0.32 & 49.472 & 1.17 & 0.0484 & 1.16 & 129.0 & 1.5 & 120.2 & 27.1 & 129.0 & 1.5 \\
\hline CM19_25 & 614.4 & 0.33 & 50.380 & 1.34 & 0.0478 & 1.10 & 126.7 & 1.7 & 86.9 & 25.8 & 126.7 & 1.7 \\
\hline CM19_24 & 836.8 & 0.26 & 49.519 & 1.09 & 0.0492 & 0.95 & 128.9 & 1.4 & 159.4 & 22.1 & 128.9 & 1.4 \\
\hline CM19_23 & 1462.4 & 0.27 & 47.177 & 1.02 & 0.0513 & 0.87 & 135.2 & 1.4 & 253.0 & 19.9 & 135.2 & 1.4 \\
\hline CM19_22 & 3281.3 & 0.30 & 47.503 & 0.99 & 0.0526 & 0.59 & 134.3 & 1.3 & 312.8 & 13.4 & 134.3 & 1.3 \\
\hline CM19_21 & 253.4 & 0.33 & 48.345 & 1.34 & 0.0502 & 1.33 & 132.0 & 1.8 & 203.6 & 30.7 & 132.0 & 1.8 \\
\hline
\end{tabular}




\begin{tabular}{|c|c|c|c|c|c|c|c|c|c|c|c|c|}
\hline CM19_20 & 359.8 & 0.30 & 47.053 & 1.25 & 0.0496 & 1.00 & 135.6 & 1.7 & 174.1 & 23.2 & 135.6 & 1.7 \\
\hline CM19_19 & 929.6 & 0.36 & 46.574 & 0.91 & 0.0558 & 0.87 & 136.9 & 1.2 & 443.8 & 19.2 & 136.9 & 1.2 \\
\hline CM19_18 & 513.1 & 0.31 & 47.931 & 1.12 & 0.0485 & 1.14 & 133.1 & 1.5 & 122.3 & 26.6 & 133.1 & 1.5 \\
\hline CM19_16 & 1148.9 & 0.57 & 49.880 & 0.95 & 0.0568 & 0.78 & 128.0 & 1.2 & 483.1 & 17.1 & 128.0 & 1.2 \\
\hline CM19_15 & 2620.9 & 0.42 & 46.990 & 1.04 & 0.0522 & 0.65 & 135.7 & 1.4 & 295.5 & 14.7 & 135.7 & 1.4 \\
\hline CM19_14 & 703.7 & 0.27 & 49.021 & 1.45 & 0.0504 & 0.95 & 130.2 & 1.9 & 215.6 & 21.8 & 130.2 & 1.9 \\
\hline CM19_13 & 387.1 & 0.33 & 48.143 & 1.22 & 0.0492 & 1.02 & 132.5 & 1.6 & 155.9 & 23.6 & 132.5 & 1.6 \\
\hline CM19_10 & 816.5 & 0.38 & 47.830 & 1.22 & 0.0507 & 1.00 & 133.4 & 1.6 & 228.0 & 23.0 & 133.4 & 1.6 \\
\hline CM19_8 & 335.7 & 0.38 & 47.874 & 1.25 & 0.0534 & 1.59 & 133.3 & 1.6 & 347.6 & 35.6 & 133.3 & 1.6 \\
\hline CM19_7 & 2727.6 & 0.58 & 49.545 & 1.15 & 0.0489 & 0.66 & 128.8 & 1.5 & 140.8 & 15.4 & 128.8 & 1.5 \\
\hline CM19_6 & 286.0 & 0.33 & 51.473 & 1.41 & 0.0490 & 1.35 & 124.0 & 1.7 & 148.3 & 31.4 & 124.0 & 1.7 \\
\hline CM19_5 & 1042.1 & 0.31 & 49.068 & 1.12 & 0.0487 & 0.89 & 130.1 & 1.4 & 134.4 & 20.9 & 130.1 & 1.4 \\
\hline CM19_4 & 647.0 & 0.47 & 51.303 & 1.25 & 0.0502 & 1.17 & 124.4 & 1.5 & 202.5 & 26.9 & 124.4 & 1.5 \\
\hline CM19_3 & 1105.9 & 0.68 & 47.247 & 1.14 & 0.0477 & 0.77 & 135.0 & 1.5 & 85.8 & 18.2 & 135.0 & 1.5 \\
\hline CM19_1 & 1991.0 & 0.40 & 47.825 & 1.12 & 0.0483 & 0.61 & 133.4 & 1.5 & 115.5 & 14.4 & 133.4 & 1.5 \\
\hline \multicolumn{13}{|c|}{ CM17B } \\
\hline CM17B_37 & 2171.3 & 0.25 & 47.021 & 1.75 & 0.0490 & 0.44 & 135.7 & 2.4 & 148.2 & 10.3 & 135.7 & 2.4 \\
\hline CM17B_36 & 1232.7 & 0.34 & 49.800 & 1.88 & 0.0505 & 0.70 & 128.2 & 2.4 & 219.0 & 16.0 & 128.2 & 2.4 \\
\hline CM17B_33 & 919.7 & 0.50 & 50.074 & 1.80 & 0.0475 & 0.73 & 127.5 & 2.3 & 73.2 & 17.2 & 127.5 & 2.3 \\
\hline CM17B_32 & 330.1 & 0.24 & 49.106 & 2.18 & 0.0485 & 1.66 & 130.0 & 2.8 & 126.0 & 38.6 & 130.0 & 2.8 \\
\hline CM17B_30 & 252.9 & 0.27 & 47.745 & 1.83 & 0.0470 & 1.30 & 133.6 & 2.4 & 46.7 & 30.9 & 133.6 & 2.4 \\
\hline CM17B_29 & 786.3 & 0.25 & 47.482 & 1.89 & 0.0510 & 0.94 & 134.4 & 2.5 & 240.4 & 21.5 & 134.4 & 2.5 \\
\hline CM17B_28 & 188.0 & 0.25 & 47.538 & 1.90 & 0.0486 & 1.54 & 134.2 & 2.5 & 129.0 & 35.8 & 134.2 & 2.5 \\
\hline CM17B_27 & 296.0 & 0.34 & 47.746 & 1.73 & 0.0478 & 1.19 & 133.6 & 2.3 & 87.7 & 27.9 & 133.6 & 2.3 \\
\hline CM17B_26 & 269.0 & 0.26 & 48.660 & 1.78 & 0.0496 & 1.35 & 131.1 & 2.3 & 176.1 & 31.3 & 131.1 & 2.3 \\
\hline CM17B_25 & 1911.0 & 0.33 & 48.737 & 1.60 & 0.0488 & 0.57 & 130.9 & 2.1 & 137.1 & 13.2 & 130.9 & 2.1 \\
\hline CM17B_23 & 2630.5 & 0.32 & 47.279 & 1.49 & 0.0491 & 0.50 & 134.9 & 2.0 & 151.7 & 11.6 & 134.9 & 2.0 \\
\hline CM17B_22 & 667.0 & 0.44 & 48.802 & 1.58 & 0.0493 & 0.86 & 130.8 & 2.0 & 164.1 & 19.9 & 130.8 & 2.0 \\
\hline CM17B_21 & 2493.3 & 0.47 & 48.848 & 1.62 & 0.0494 & 0.70 & 130.6 & 2.1 & 167.6 & 16.2 & 130.6 & 2.1 \\
\hline CM17B_20 & 1127.0 & 0.30 & 47.835 & 1.53 & 0.0498 & 0.65 & 133.4 & 2.0 & 183.3 & 15.1 & 133.4 & 2.0 \\
\hline
\end{tabular}




\begin{tabular}{|c|c|c|c|c|c|c|c|c|c|c|c|c|}
\hline CM17B_19 & 1068.1 & 0.36 & 48.196 & 1.52 & 0.0491 & 0.70 & 132.4 & 2.0 & 151.1 & 16.4 & 132.4 & 2.0 \\
\hline CM17B_18 & 649.1 & 0.33 & 45.884 & 1.60 & 0.0506 & 0.80 & 139.0 & 2.2 & 221.8 & 18.3 & 139.0 & 2.2 \\
\hline CM17B_16 & 1208.6 & 0.33 & 49.818 & 1.56 & 0.0485 & 0.59 & 128.1 & 2.0 & 122.7 & 13.9 & 128.1 & 2.0 \\
\hline CM17B_15 & 955.7 & 0.26 & 47.895 & 1.54 & 0.0514 & 0.73 & 133.2 & 2.0 & 257.8 & 16.7 & 133.2 & 2.0 \\
\hline CM17B_14 & 1537.4 & 0.36 & 48.057 & 1.42 & 0.0490 & 0.60 & 132.8 & 1.9 & 149.8 & 14.1 & 132.8 & 1.9 \\
\hline CM17B_13 & 1508.5 & 0.25 & 48.763 & 1.46 & 0.0491 & 0.71 & 130.9 & 1.9 & 152.1 & 16.7 & 130.9 & 1.9 \\
\hline CM17B_12 & 2165.8 & 0.28 & 49.745 & 1.53 & 0.0488 & 0.64 & 128.3 & 1.9 & 139.4 & 14.9 & 128.3 & 1.9 \\
\hline CM17B_11 & 1484.7 & 0.27 & 49.204 & 1.46 & 0.0495 & 0.72 & 129.7 & 1.9 & 170.4 & 16.7 & 129.7 & 1.9 \\
\hline CM17B_10 & 2301.3 & 0.33 & 48.544 & 1.44 & 0.0524 & 0.62 & 131.4 & 1.9 & 303.8 & 14.1 & 131.4 & 1.9 \\
\hline CM17B_9 & 227.1 & 0.26 & 46.722 & 1.71 & 0.0682 & 1.23 & 136.5 & 2.3 & 875.6 & 25.3 & 136.5 & 2.3 \\
\hline CM17B_8 & 742.4 & 0.38 & 47.988 & 1.58 & 0.0536 & 1.14 & 133.0 & 2.1 & 354.5 & 25.6 & 133.0 & 2.1 \\
\hline CM17B_7 & 224.0 & 0.23 & 47.839 & 1.75 & 0.0486 & 1.40 & 133.4 & 2.3 & 129.8 & 32.6 & 133.4 & 2.3 \\
\hline CM17B_6 & 700.3 & 0.32 & 47.141 & 1.59 & 0.0506 & 0.88 & 135.3 & 2.1 & 224.5 & 20.2 & 135.3 & 2.1 \\
\hline CM17B_5 & 359.1 & 0.30 & 47.887 & 1.62 & 0.0492 & 1.08 & 133.2 & 2.1 & 156.2 & 25.1 & 133.2 & 2.1 \\
\hline CM17B_4 & 903.0 & 0.54 & 47.151 & 1.75 & 0.0592 & 1.27 & 135.3 & 2.3 & 573.6 & 27.3 & 135.3 & 2.3 \\
\hline CM17B_3 & 2482.3 & 0.22 & 46.728 & 1.43 & 0.0492 & 0.54 & 136.5 & 1.9 & 157.2 & 12.5 & 136.5 & 9 \\
\hline \multicolumn{13}{|c|}{ CM4 } \\
\hline CM4_44 & 301.0 & 0.56 & 47.486 & 1.64 & 0.1001 & 1.75 & 134.3 & 2.2 & 1626.6 & 32.2 & 1626.6 & 2.2 \\
\hline CM4_43 & 1559.3 & 0.54 & 47.694 & 1.46 & 0.0486 & 1.05 & 133.8 & 1.9 & 130.6 & 24.6 & 133.8 & 1.9 \\
\hline CM4_42 & 731.2 & 0.42 & 50.227 & 1.34 & 0.0522 & 1.51 & 127.1 & 1.7 & 292.4 & 34.1 & 127.1 & 1.7 \\
\hline CM4_41 & 925.2 & 0.46 & 46.435 & 1.30 & 0.0496 & 1.24 & 137.4 & 1.8 & 175.0 & 28.7 & 137.4 & 1.8 \\
\hline CM4_40 & 458.7 & 0.39 & 47.763 & 1.41 & 0.0523 & 1.44 & 133.6 & 1.9 & 297.0 & 32.4 & 133.6 & 1.9 \\
\hline CM4_39 & 604.6 & 0.38 & 47.933 & 1.37 & 0.0490 & 1.54 & 133.1 & 1.8 & 150.2 & 35.7 & 133.1 & 1.8 \\
\hline CM4_38 & 898.0 & 0.40 & 48.263 & 1.58 & 0.0510 & 1.88 & 132.2 & 2.1 & 242.2 & 42.6 & 132.2 & 2.1 \\
\hline CM4_37 & 424.5 & 0.44 & 50.159 & 1.50 & 0.0482 & 1.51 & 127.3 & 1.9 & 108.7 & 35.3 & 127.3 & 1.9 \\
\hline CM4_36 & 1467.3 & 0.37 & 49.170 & 1.38 & 0.0583 & 1.22 & 129.8 & 1.8 & 541.2 & 26.6 & 129.8 & 1.8 \\
\hline CM4_35 & 1605.3 & 0.30 & 48.414 & 1.35 & 0.0495 & 1.10 & 131.8 & 1.8 & 173.4 & 25.4 & 131.8 & 1.8 \\
\hline CM4_34 & 707.3 & 0.46 & 47.334 & 1.39 & 0.0522 & 1.38 & 134.8 & 1.9 & 296.2 & 31.3 & 134.8 & 1.9 \\
\hline CM4_33 & 775.4 & 0.55 & 48.620 & 1.34 & 0.0726 & 1.88 & 131.2 & 1.7 & 1002.1 & 37.6 & 131.2 & 1.7 \\
\hline CM4_32 & 702.1 & 0.45 & 51.395 & 1.71 & 0.0528 & 2.11 & 124.2 & 2.1 & 321.6 & 47.2 & 124.2 & 2.1 \\
\hline
\end{tabular}




\begin{tabular}{|c|c|c|c|c|c|c|c|c|c|c|c|c|}
\hline CM4_31 & 1065.9 & 0.40 & 49.132 & 1.32 & 0.0504 & 1.15 & 129.9 & 1.7 & 212.3 & 26.4 & 129.9 & 1.7 \\
\hline CM4_30 & 1491.3 & 0.26 & 46.663 & 1.30 & 0.0493 & 1.08 & 136.7 & 1.8 & 160.9 & 25.2 & 136.7 & 1.8 \\
\hline CM4_29 & 1281.9 & 0.47 & 46.613 & 1.32 & 0.0493 & 1.14 & 136.8 & 1.8 & 161.1 & 26.4 & 136.8 & 1.8 \\
\hline CM4_28 & 2533.4 & 0.68 & 48.005 & 1.58 & 0.0503 & 1.60 & 132.9 & 2.1 & 209.9 & 36.6 & 132.9 & 2.1 \\
\hline CM4_27 & 579.5 & 0.31 & 50.215 & 1.28 & 0.0577 & 2.36 & 127.1 & 1.6 & 517.4 & 51.0 & 127.1 & 1.6 \\
\hline CM4_26 & 1035.9 & 0.44 & 50.544 & 1.16 & 0.0483 & 1.26 & 126.3 & 1.5 & 111.7 & 29.5 & 126.3 & 1.5 \\
\hline CM4_25 & 587.8 & 0.30 & 49.246 & 1.19 & 0.0505 & 1.62 & 129.6 & 1.5 & 219.4 & 37.2 & 129.6 & 1.5 \\
\hline CM4_23 & 2532.9 & 0.34 & 50.230 & 1.05 & 0.0488 & 1.01 & 127.1 & 1.3 & 138.9 & 23.5 & 127.1 & 1.3 \\
\hline CM4_21 & 393.9 & 0.36 & 46.668 & 1.32 & 0.0486 & 1.81 & 136.7 & 1.8 & 130.8 & 42.0 & 136.7 & 1.8 \\
\hline CM4_20 & 282.3 & 0.40 & 49.455 & 1.24 & 0.0491 & 1.57 & 129.0 & 1.6 & 153.3 & 36.5 & 129.0 & 1.6 \\
\hline CM4_19 & 409.1 & 0.40 & 45.611 & 1.21 & 0.0516 & 1.43 & 139.8 & 1.7 & 266.0 & 32.5 & 139.8 & 1.7 \\
\hline CM4_18 & 947.5 & 0.37 & 48.640 & 1.10 & 0.0487 & 1.17 & 131.2 & 1.4 & 131.2 & 27.3 & 131.2 & 1.4 \\
\hline CM4_16 & 775.5 & 0.45 & 45.635 & 1.47 & 0.0510 & 1.16 & 139.7 & 2.0 & 240.2 & 26.4 & 139.7 & 2.0 \\
\hline CM4_14 & 2235.0 & 0.58 & 47.593 & 1.45 & 0.0493 & 0.82 & 134.0 & 1.9 & 160.1 & 19.2 & 134.0 & 1.9 \\
\hline CM4_13 & 1035.1 & 0.55 & 47.958 & 1.48 & 0.0559 & 0.91 & 133.0 & 1.9 & 450.4 & 20.0 & 133.0 & 1.9 \\
\hline CM4_12 & 620.1 & 0.34 & 47.511 & 1.52 & 0.0522 & 1.19 & 134.3 & 2.0 & 292.9 & 26.9 & 134.3 & 2.0 \\
\hline CM4_11 & 677.1 & 0.45 & 48.422 & 1.81 & 0.0532 & 2.25 & 131.8 & 2.4 & 338.3 & 50.1 & 131.8 & 2.4 \\
\hline CM4_10 & 265.5 & 0.28 & 46.947 & 1.67 & 0.0495 & 1.61 & 135.9 & 2.2 & 172.8 & 37.1 & 135.9 & 2.2 \\
\hline CM4_9 & 311.9 & 0.47 & 48.859 & 1.58 & 0.0497 & 1.65 & 130.6 & 2.0 & 183.0 & 38.0 & 130.6 & 2.0 \\
\hline CM4_7 & 946.6 & 0.42 & 46.224 & 1.47 & 0.0545 & 1.00 & 138.0 & 2.0 & 391.1 & 22.2 & 138.0 & 2.0 \\
\hline CM4_6 & 1770.8 & 0.40 & 44.671 & 1.45 & 0.0537 & 0.88 & 142.7 & 2.0 & 356.6 & 19.7 & 142.7 & 2.0 \\
\hline CM4_5 & 1277.0 & 0.31 & 48.105 & 1.46 & 0.0499 & 0.92 & 132.6 & 1.9 & 190.5 & 21.3 & 132.6 & 1.9 \\
\hline CM4_4 & 440.1 & 0.33 & 45.532 & 1.56 & 0.0514 & 1.43 & 140.0 & 2.2 & 256.6 & 32.5 & 140.0 & 2.2 \\
\hline CM4_3 & 631.5 & 0.31 & 46.601 & 1.94 & 0.0518 & 2.39 & 136.9 & 2.6 & 275.3 & 53.9 & 136.9 & 2.6 \\
\hline CM4_2 & 485.0 & 0.37 & 46.073 & 1.50 & 0.0486 & 1.29 & 138.4 & 2.1 & 130.2 & 30.0 & 138.4 & 2.1 \\
\hline CM4_1 & 325.6 & 0.25 & 46.456 & 2.03 & 0.0525 & 2.10 & 137.3 & 2.8 & 308.1 & 47.2 & 137.3 & 2.8 \\
\hline \multicolumn{13}{|c|}{ CM10 } \\
\hline CM10_49 & 2005.0 & 0.45 & 47.762 & 1.04 & 0.0493 & 0.83 & 133.6 & 1.4 & 161.0 & 19.4 & 133.6 & 1.4 \\
\hline CM10_48 & 805.8 & 0.32 & 47.122 & 1.21 & 0.0673 & 1.26 & 135.4 & 1.6 & 848.2 & 25.9 & 135.4 & 1.6 \\
\hline CM10_47 & 1394.0 & 0.30 & 47.747 & 1.15 & 0.0500 & 0.98 & 133.6 & 1.5 & 195.7 & 22.7 & 133.6 & 1.5 \\
\hline
\end{tabular}




\begin{tabular}{|c|c|c|c|c|c|c|c|c|c|c|c|}
\hline CM10_45 & 1839.6 & 0.36 & 48.194 & 1.17 & 0.0490 & 1.14 & 132.4 & 1.5 & 146.6 & 26.5 & 132.4 \\
\hline CM10_44 & 1108.4 & 0.32 & 47.649 & 1.10 & 0.0507 & 0.99 & 133.9 & 1.5 & 228.9 & 22.7 & 133.9 \\
\hline CM10_43 & 587.1 & 0.36 & 47.797 & 1.13 & 0.0489 & 1.21 & 133.5 & 1.5 & 140.7 & 28.1 & 133.5 \\
\hline CM10_42 & 752.2 & 0.28 & 46.721 & 1.12 & 0.0483 & 1.05 & 136.5 & 1.5 & 112.5 & 24.6 & 136.5 \\
\hline CM10_41 & 3690.4 & 0.22 & 48.025 & 1.05 & 0.0515 & 0.76 & 132.9 & 1.4 & 262.6 & 17.4 & 132.9 \\
\hline CM10_38 & 784.0 & 0.22 & 46.131 & 1.12 & 0.0489 & 1.16 & 138.2 & 1.5 & 144.2 & 26.9 & 138.2 \\
\hline CM10_36 & 950.7 & 0.21 & 48.781 & 1.14 & 0.0505 & 1.01 & 130.8 & 1.5 & 218.7 & 23.2 & 130.8 \\
\hline CM10_35 & 827.3 & 0.26 & 48.568 & 1.18 & 0.0534 & 1.11 & 131.4 & 1.5 & 344.3 & 24.9 & 131.4 \\
\hline CM10_34 & 1320.7 & 0.27 & 48.266 & 1.11 & 0.0520 & 0.89 & 132.2 & 1.5 & 283.8 & 20.2 & 132.2 \\
\hline CM10_33 & 1474.6 & 0.20 & 47.441 & 1.11 & 0.0501 & 0.96 & 134.5 & 1.5 & 200.8 & 22.1 & 134.5 \\
\hline CM10_32 & 2336.7 & 0.23 & 48.508 & 1.16 & 0.0492 & 1.06 & 131.5 & 1.5 & 159.6 & 24.5 & 131.5 \\
\hline CM10_31 & 262.3 & 0.22 & 48.411 & 1.29 & 0.0488 & 1.74 & 131.8 & 1.7 & 136.1 & 40.4 & 131.8 \\
\hline CM10_30 & 1744.3 & 0.27 & 47.692 & 1.20 & 0.0547 & 0.98 & 133.8 & 1.6 & 399.7 & 21.7 & 133.8 \\
\hline CM10_28 & 2941.2 & 0.37 & 47.208 & 1.07 & 0.0492 & 0.77 & 135.1 & 1.4 & 158.5 & 17.9 & 135.1 \\
\hline CM10_27 & 1166.5 & 0.33 & 47.119 & 1.14 & 0.0493 & 0.91 & 135.4 & 1.5 & 160.4 & 21.1 & 135.4 \\
\hline CM10_26 & 987.2 & 0.25 & 48.001 & 1.22 & 0.0489 & 1.29 & 132.9 & 1.6 & 142.1 & 30.0 & 132.9 \\
\hline CM10_24 & 217.1 & 0.24 & 46.332 & 1.30 & 0.0501 & 2.05 & 137.7 & 1.8 & 199.2 & 47.0 & 137.7 \\
\hline CM10_23 & 1130.8 & 0.22 & 47.673 & 1.10 & 0.0528 & 1.04 & 133.8 & 1.5 & 318.2 & 23.5 & 133.8 \\
\hline CM10_22 & 2103.4 & 0.62 & 48.552 & 1.10 & 0.0493 & 0.83 & 131.4 & 1.4 & 161.2 & 19.2 & 131.4 \\
\hline CM10_21 & 302.5 & 0.40 & 46.768 & 1.26 & 0.0493 & 1.47 & 136.4 & 1.7 & 161.1 & 34.0 & 136.4 \\
\hline CM10_20 & 1057.6 & 0.30 & 47.169 & 1.22 & 0.0519 & 1.03 & 135.2 & 1.6 & 281.1 & 23.4 & 135.2 \\
\hline CM10_18 & 641.3 & 0.24 & 47.045 & 1.00 & 0.0500 & 1.37 & 135.6 & 1.3 & 196.2 & 31.6 & 135.6 \\
\hline CM10_17 & 477.5 & 0.23 & 47.865 & 0.94 & 0.0524 & 1.18 & 133.3 & 1.2 & 300.8 & 26.6 & 133.3 \\
\hline CM10_16 & 2153.4 & 0.31 & 47.146 & 0.88 & 0.0645 & 1.80 & 135.3 & 1.2 & 757.8 & 37.5 & 135.3 \\
\hline CM10_15 & 675.8 & 0.20 & 47.163 & 0.94 & 0.0514 & 1.09 & 135.3 & 1.3 & 256.9 & 24.9 & 135.3 \\
\hline CM10_14 & 282.2 & 0.34 & 48.297 & 1.06 & 0.0504 & 1.67 & 132.1 & 1.4 & 212.8 & 38.1 & 132.1 \\
\hline CM10_13 & 2363.0 & 0.32 & 47.911 & 0.88 & 0.0512 & 0.71 & 133.2 & 1.2 & 248.5 & 16.3 & 133.2 \\
\hline CM10_12 & 740.8 & 0.38 & 47.593 & 0.91 & 0.0493 & 0.98 & 134.0 & 1.2 & 162.4 & 22.9 & 134.0 \\
\hline CM10_11 & 1934.0 & 0.46 & 47.391 & 0.85 & 0.0503 & 0.69 & 134.6 & 1.1 & 208.1 & 15.9 & 134.6 \\
\hline CM10_10 & 2641.8 & 0.34 & 48.161 & 0.88 & 0.0489 & 0.63 & 132.5 & 1.1 & 143.9 & 14.8 & 132.5 \\
\hline
\end{tabular}




\begin{tabular}{|c|c|c|c|c|c|c|c|c|c|c|c|c|}
\hline CM10_9 & 1509.2 & 0.34 & 48.535 & 0.88 & 0.0502 & 0.72 & 131.5 & 1.1 & 202.0 & 16.6 & 131.5 & 1.1 \\
\hline CM10_8 & 342.5 & 0.26 & 48.918 & 1.45 & 0.0503 & 1.50 & 130.5 & 1.9 & 207.1 & 34.3 & 130.5 & 1.9 \\
\hline CM10_7 & 1202.5 & 0.21 & 46.916 & 1.35 & 0.0488 & 0.76 & 136.0 & 1.8 & 137.6 & 17.8 & 136.0 & 1.8 \\
\hline CM10_6 & 1290.1 & 0.39 & 48.620 & 1.31 & 0.0487 & 0.88 & 131.2 & 1.7 & 134.3 & 20.5 & 131.2 & 1.7 \\
\hline CM10_5 & 1434.8 & 0.39 & 49.231 & 1.28 & 0.0495 & 0.78 & 129.6 & 1.6 & 172.1 & 18.1 & 129.6 & 1.6 \\
\hline CM10_4 & 2475.0 & 0.37 & 47.781 & 1.31 & 0.0491 & 0.95 & 133.5 & 1.7 & 153.9 & 22.0 & 133.5 & 1.7 \\
\hline CM10_3 & 1654.8 & 0.34 & 49.127 & 1.36 & 0.0500 & 0.81 & 129.9 & 1.7 & 193.1 & 18.8 & 129.9 & 1.7 \\
\hline CM10_2 & 670.9 & 0.21 & 48.386 & 1.58 & 0.0473 & 1.77 & 131.9 & 2.1 & 63.9 & 41.8 & 131.9 & 2.1 \\
\hline CM10_1 & 3894.3 & 0.21 & 50.812 & 1.39 & 0.0501 & 0.70 & 125.6 & 1.7 & 200.3 & 16.2 & 125.6 & 1.7 \\
\hline \multicolumn{13}{|c|}{ GCC1 } \\
\hline GCC1-1 & 1108.4 & 0.19 & 47.262 & 0.01 & 0.0493 & 0.01 & 135.0 & 1.8 & 161.8 & 22.8 & 135.0 & 1.8 \\
\hline GCC1-2 & 394.9 & 0.22 & 47.491 & 0.01 & 0.0485 & 0.03 & 134.3 & 1.1 & 125.6 & 71.1 & 134.3 & 1.1 \\
\hline GCC1-3 & 1074.9 & 0.15 & 47.434 & 0.02 & 0.0496 & 0.02 & 134.5 & 2.1 & 178.3 & 46.6 & 134.5 & 2.1 \\
\hline GCC1-4 & 1425.2 & 0.11 & 47.779 & 0.03 & 0.0479 & 0.05 & 133.5 & 3.8 & 94.1 & 127.4 & 133.5 & 3.8 \\
\hline GCC1-5 & 1879.2 & 0.48 & 47.738 & 0.01 & 0.0608 & 0.09 & 133.6 & 0.9 & 632.2 & 192.9 & 133.6 & 0.9 \\
\hline GCC1-6 & 1251.0 & 0.29 & 47.839 & 0.01 & 0.0542 & 0.10 & 133.4 & 1.6 & 380.2 & 226.6 & 133.4 & 1.6 \\
\hline GCC1-7 & 1424.9 & 0.18 & 46.290 & 0.01 & 0.0491 & 0.01 & 137.8 & 0.7 & 150.6 & 34.5 & 137.8 & 0.7 \\
\hline GCC1-8 & 1203.8 & 0.38 & 47.381 & 0.01 & 0.0493 & 0.02 & 134.6 & 0.8 & 162.7 & 42.2 & 134.6 & 0.8 \\
\hline GCC1-9 & 419.7 & 0.16 & 45.544 & 0.01 & 0.0485 & 0.03 & 140.0 & 0.7 & 121.9 & 65.0 & 140.0 & 0.7 \\
\hline GCC1-10 & 751.6 & 0.22 & 47.301 & 0.01 & 0.0504 & 0.03 & 134.9 & 1.4 & 214.2 & 72.3 & 134.9 & 1.4 \\
\hline GCC1-13 & 914.8 & 0.22 & 47.048 & 0.01 & 0.0489 & 0.02 & 135.6 & 0.7 & 145.3 & 44.4 & 135.6 & 0.7 \\
\hline GCC1-14 & 1055.3 & 0.18 & 47.943 & 0.01 & 0.0538 & 0.14 & 133.1 & 1.6 & 361.7 & 317.9 & 133.1 & 1.6 \\
\hline GCC1-15 & 1104.5 & 0.36 & 46.715 & 0.02 & 0.0552 & 0.06 & 136.5 & 3.3 & 420.5 & 138.3 & 136.5 & 3.3 \\
\hline GCC1-16 & 1133.5 & 0.13 & 47.988 & 0.01 & 0.0511 & 0.18 & 133.0 & 1.0 & 246.4 & 425.3 & 133.0 & 1.0 \\
\hline GCC1-18 & 585.0 & 0.26 & 46.533 & 0.01 & 0.0497 & 0.02 & 137.1 & 1.0 & 180.9 & 58.0 & 137.1 & 1.0 \\
\hline GCC1-19 & 1311.4 & 0.14 & 47.175 & 0.01 & 0.0488 & 0.01 & 135.2 & 1.1 & 140.2 & 18.8 & 135.2 & 1.1 \\
\hline GCC1-20 & 651.3 & 0.28 & 47.354 & 0.01 & 0.0480 & 0.02 & 134.7 & 0.7 & 98.1 & 53.1 & 134.7 & 0.7 \\
\hline GCC1-22 & 1762.0 & 0.21 & 47.477 & 0.01 & 0.0493 & 0.01 & 134.4 & 1.8 & 163.3 & 23.3 & 134.4 & 1.8 \\
\hline GCC1-25 & 912.3 & 0.18 & 47.038 & 0.02 & 0.0498 & 0.01 & 135.6 & 2.2 & 186.9 & 19.4 & 135.6 & 2.2 \\
\hline GCC1-26 & 3171.2 & 0.25 & 47.174 & 0.01 & 0.0516 & 0.02 & 135.2 & 2.0 & 266.2 & 39.1 & 135.2 & 2.0 \\
\hline
\end{tabular}




\begin{tabular}{|c|c|c|c|c|c|c|c|c|c|c|c|}
\hline GCC1-27 & 881.0 & 0.21 & 46.678 & 0.01 & 0.0588 & 0.20 & 136.6 & 1.2 & 559.9 & 449.5 & 136.6 \\
\hline GCC1-28 & 2266.8 & 0.22 & 47.720 & 0.01 & 0.0503 & 0.01 & 133.7 & 1.4 & 210.2 & 30.7 & 133.7 \\
\hline GCC1-29 & 1092.6 & 0.33 & 47.457 & 0.01 & 0.0547 & 0.16 & 134.4 & 1.2 & 400.0 & 352.4 & 134.4 \\
\hline GCC1-30 & 1951.8 & 0.41 & 47.284 & 0.01 & 0.0492 & 0.03 & 134.9 & 1.1 & 156.7 & 71.8 & 134.9 \\
\hline GCC1-31 & 3091.1 & 0.41 & 47.016 & 0.01 & 0.0503 & 0.02 & 135.7 & 0.9 & 208.3 & 37.7 & 135.7 \\
\hline GCC1-32 & 1040.2 & 0.25 & 47.504 & 0.01 & 0.0503 & 0.02 & 134.3 & 0.7 & 208.0 & 48.1 & 134.3 \\
\hline GCC1-33 & 64.0 & 6.15 & 47.581 & 0.01 & 0.0546 & 0.05 & 134.1 & 1.2 & 395.0 & 103.8 & 134.1 \\
\hline GCC1-35 & 1631.8 & 0.29 & 47.127 & 0.01 & 0.0516 & 0.01 & 135.4 & 1.2 & 266.3 & 23.8 & 135.4 \\
\hline GCC1-36 & 876.0 & 0.29 & 47.535 & 0.02 & 0.0490 & 0.02 & 134.2 & 2.2 & 147.0 & 36.6 & 134.2 \\
\hline GCC1-37 & 1639.7 & 0.19 & 47.537 & 0.01 & 0.0491 & 0.01 & 134.2 & 0.8 & 151.1 & 26.9 & 134.2 \\
\hline GCC1-38 & 312.0 & 0.16 & 47.541 & 0.01 & 0.0491 & 0.05 & 134.2 & 1.6 & 154.2 & 108.4 & 134.2 \\
\hline GCC1-39 & 566.6 & 0.25 & 47.196 & 0.01 & 0.0500 & 0.03 & 135.2 & 1.0 & 192.8 & 74.5 & 135.2 \\
\hline GCC1-40 & 2017.4 & 0.26 & 47.014 & 0.01 & 0.0495 & 0.01 & 135.7 & 1.1 & 171.6 & 18.2 & 135.7 \\
\hline GCC1-41 & 850.0 & 0.35 & 47.284 & 0.01 & 0.0520 & 0.03 & 134.9 & 0.7 & 285.0 & 64.6 & 134.9 \\
\hline GCC1-43 & 453.5 & 0.17 & 47.126 & 0.02 & 0.0487 & 0.02 & 135.4 & 2.9 & 133.4 & 47.9 & 135.4 \\
\hline GCC1-45 & 602.6 & 0.08 & 47.677 & 0.01 & 0.0517 & 0.05 & 133.8 & 1.6 & 273.4 & 103.6 & 133.8 \\
\hline \multicolumn{12}{|c|}{ GCC7A } \\
\hline GCC7A-1 & 213.9 & 0.28 & 44.464 & 0.01 & 0.0481 & 0.06 & 143.4 & 1.0 & 105.5 & 141.2 & 143.4 \\
\hline GCC7A-2 & 1126.1 & 0.34 & 44.126 & 0.01 & 0.0503 & 0.02 & 144.5 & 1.8 & 210.4 & 38.6 & 144.5 \\
\hline GCC7A-3 & 545.3 & 0.29 & 44.994 & 0.02 & 0.0592 & 0.14 & 141.7 & 2.2 & 573.7 & 301.5 & 141.7 \\
\hline GCC7A-4 & 1258.3 & 0.17 & 44.982 & 0.01 & 0.0488 & 0.03 & 141.7 & 1.9 & 138.5 & 59.6 & 141.7 \\
\hline GCC7A-5 & 784.2 & 0.38 & 44.303 & 0.01 & 0.0484 & 0.14 & 143.9 & 1.5 & 119.3 & 323.3 & 143.9 \\
\hline GCC7A-6 & 1460.0 & 0.18 & 44.734 & 0.01 & 0.0504 & 0.02 & 142.5 & 0.7 & 214.4 & 45.7 & 142.5 \\
\hline GCC7A-8 & 1051.5 & 0.13 & 44.314 & 0.01 & 0.0498 & 0.01 & 143.9 & 0.7 & 185.0 & 30.9 & 143.9 \\
\hline GCC7A-10 & 613.2 & 0.21 & 44.345 & 0.01 & 0.0482 & 0.01 & 143.8 & 0.7 & 111.2 & 35.2 & 143.8 \\
\hline GCC7A-11 & 367.4 & 0.20 & 44.844 & 0.01 & 0.0476 & 0.05 & 142.2 & 1.2 & 78.7 & 116.9 & 142.2 \\
\hline GCC7A-12 & 405.7 & 0.22 & 44.548 & 0.02 & 0.0483 & 0.04 & 143.1 & 2.7 & 112.7 & 92.6 & 143.1 \\
\hline GCC7A-13 & 478.9 & 0.20 & 44.722 & 0.01 & 0.0473 & 0.14 & 142.6 & 1.8 & 62.2 & 328.5 & 142.6 \\
\hline GCC7A-14 & 339.0 & 0.18 & 44.668 & 0.01 & 0.0483 & 0.03 & 142.7 & 0.7 & 111.7 & 72.9 & 142.7 \\
\hline GCC7A-15 & 253.8 & 0.19 & 45.051 & 0.01 & 0.0469 & 0.04 & 141.5 & 1.7 & 44.8 & 103.7 & 141.5 \\
\hline
\end{tabular}




\begin{tabular}{lllllllllllll} 
GCC7A-17 & 274.8 & 0.22 & 44.853 & 0.01 & 0.0477 & 0.09 & 142.1 & 1.7 & 85.1 & 209.5 & 142.1 & 1.7 \\
GCC7A-18 & 884.9 & 0.20 & 44.203 & 0.01 & 0.0478 & 0.03 & 144.2 & 0.8 & 87.8 & 71.4 & 144.2 & 0.8 \\
GCC7A-19 & 661.5 & 0.19 & 44.488 & 0.01 & 0.0479 & 0.02 & 143.3 & 0.8 & 96.2 & 53.7 & 143.3 & 0.8 \\
GCC7A-20 & 542.2 & 0.27 & 44.168 & 0.01 & 0.0487 & 0.04 & 144.3 & 1.0 & 135.5 & 91.0 & 144.3 & 1.0 \\
GCC7A-21 & 730.0 & 0.17 & 44.285 & 0.01 & 0.0483 & 0.01 & 143.9 & 0.9 & 113.5 & 35.3 & 143.9 & 0.9 \\
GCC7A-22 & 437.3 & 0.21 & 44.260 & 0.01 & 0.0483 & 0.02 & 144.0 & 0.7 & 116.2 & 43.2 & 144.0 & 0.7 \\
GCC7A-25 & 422.9 & 0.39 & 44.461 & 0.01 & 0.0498 & 0.13 & 143.4 & 1.4 & 183.3 & 299.4 & 143.4 & 1.4 \\
GCC7A-26 & 513.4 & 0.31 & 44.198 & 0.01 & 0.0500 & 0.06 & 144.2 & 1.2 & 196.2 & 139.5 & 144.2 & 1.2 \\
GCC7A-27 & 1143.1 & 0.25 & 44.203 & 0.01 & 0.0493 & 0.02 & 144.2 & 0.8 & 160.6 & 45.2 & 144.2 & 0.8 \\
GCC7A-28 & 583.8 & 0.31 & 44.544 & 0.01 & 0.0480 & 0.03 & 143.1 & 1.1 & 97.0 & 77.4 & 143.1 & 1.1 \\
\hline
\end{tabular}


Table 3.2. Hf isotopic data from the Payandé, Ibagué and Mariquita plutons.

\begin{tabular}{|c|c|c|c|c|c|c|c|c|c|c|c|c|c|c|c|}
\hline Sample & ${ }^{176} \mathrm{Hf} /{ }^{177} \mathrm{Hf}$ & $\begin{array}{c}2 \sigma \text { error } \\
\left(\times 10^{-6}\right)\end{array}$ & ${ }^{176} \mathrm{Lu} /{ }^{177} \mathrm{Hf}$ & $\begin{array}{c}2 \sigma \text { error } \\
\left(\times 10^{-5}\right)\end{array}$ & ${ }^{176} \mathrm{Yb} /{ }^{177} \mathrm{Hf}$ & $\begin{array}{c}2 \sigma \text { error } \\
\left(\times 10^{-5}\right)\end{array}$ & ${ }^{178} \mathrm{Hf} /{ }^{177} \mathrm{Hf}$ & $\begin{array}{c}2 \sigma \text { error } \\
\left(\mathrm{x} 10^{-6}\right)\end{array}$ & ${ }^{180} \mathrm{Hf} /{ }^{177} \mathrm{Hf}$ & $\begin{array}{c}2 \sigma \text { error } \\
\left(\times 10^{-6}\right)\end{array}$ & $\begin{array}{c}{ }^{238} \mathrm{U} /{ }^{206} \mathrm{~Pb} \\
\mathrm{Age}\end{array}$ & ${ }^{176} \mathrm{Hf} /{ }^{177} \mathrm{Hf}_{\mathrm{i}}$ & $\varepsilon \mathrm{Hf}_{0}$ & $\begin{array}{l}2 \sigma \\
\text { error }\end{array}$ & $\varepsilon \mathrm{Hf}_{\mathrm{i}}$ \\
\hline \multirow{2}{*}{\multicolumn{16}{|c|}{$\begin{array}{c}\text { Payandé stock } \\
\text { CSP3 }\end{array}$}} \\
\hline & & & & & & & & & & & & & & & \\
\hline CSP3 & 0.282783 & 28 & 0.00118 & 2.5 & 0.02933 & 36 & 1.467141 & 36 & 1.886965 & 71 & 169.4 & 0.282779 & -0.1 & 1.0 & 3.6 \\
\hline CSP3 & 0.282789 & 27 & 0.00103 & 6.8 & 0.02550 & 180 & 1.467188 & 31 & 1.887024 & 97 & 162.7 & 0.282786 & 0.1 & 1.0 & 3.6 \\
\hline CSP3 & 0.282765 & 29 & 0.00123 & 4.4 & 0.03212 & 91 & 1.467178 & 31 & 1.886971 & 90 & 165.7 & 0.282761 & -0.7 & 1.0 & 2.8 \\
\hline CSP3 & 0.282753 & 26 & 0.00121 & 12.0 & 0.03110 & 330 & 1.467161 & 34 & 1.886979 & 99 & 161.4 & 0.282749 & -1.1 & 0.9 & 2.3 \\
\hline CSP3 & 0.282769 & 28 & 0.00108 & 3.7 & 0.02686 & 96 & 1.467143 & 26 & 1.886930 & 110 & 152.6 & 0.282766 & -0.6 & 1.0 & 2.7 \\
\hline CSP3 & 0.282775 & 26 & 0.00068 & 5.2 & 0.01550 & 110 & 1.467139 & 30 & 1.886958 & 83 & 164.6 & 0.282773 & -0.4 & 0.9 & 3.2 \\
\hline CSP3 & 0.282790 & 26 & 0.00139 & 19.0 & 0.03640 & 560 & 1.467139 & 34 & 1.886868 & 82 & 165.6 & 0.282786 & 0.2 & 0.9 & 3.7 \\
\hline CSP3 & 0.282776 & 24 & 0.00099 & 4.9 & 0.02540 & 130 & $\begin{array}{l}1.467147 \\
\text { CSP } 5\end{array}$ & 26 & 1.886883 & 80 & 152.0 & 0.282773 & -0.3 & 0.8 & 3.0 \\
\hline CSP5 & 0.282786 & 29 & 0.00093 & 11.0 & 0.02120 & 250 & 1.467166 & 26 & 1.887005 & 85 & 155.6 & 0.282783 & 0.0 & 1.0 & 3.4 \\
\hline CSP5 & 0.282773 & 22 & 0.00065 & 3.5 & 0.01539 & 79 & 1.467152 & 36 & 1.886890 & 95 & 162.0 & 0.282771 & -0.4 & 0.8 & 3.1 \\
\hline CSP5 & 0.282767 & 27 & 0.00073 & 2.2 & 0.01819 & 60 & 1.467138 & 38 & 1.886833 & 91 & 164.7 & 0.282765 & -0.6 & 1.0 & 2.9 \\
\hline CSP5 & 0.282761 & 28 & 0.00073 & 2.7 & 0.01707 & 62 & 1.467145 & 25 & 1.886903 & 91 & 166.6 & 0.282759 & -0.8 & 1.0 & 2.8 \\
\hline CSP5 & 0.282773 & 29 & 0.00104 & 1.7 & 0.02425 & 42 & 1.467155 & 33 & 1.886869 & 89 & 164.1 & 0.282770 & -0.4 & 1.0 & 3.1 \\
\hline CSP5 & 0.282754 & 25 & 0.00077 & 3.3 & 0.01752 & 75 & 1.467176 & 25 & 1.886980 & 100 & 166.2 & 0.282752 & -1.1 & 0.9 & 2.5 \\
\hline CSP5 & 0.282752 & 28 & 0.00088 & 2.0 & 0.01999 & 52 & 1.467128 & 36 & 1.887011 & 79 & 167.0 & 0.282749 & -1.2 & 1.0 & 2.4 \\
\hline CSP5 & 0.282801 & 30 & 0.00121 & 20.0 & 0.03060 & 510 & 1.467131 & 39 & 1.886918 & 93 & 163.6 & 0.282797 & 0.6 & 1.1 & 4.1 \\
\hline \multicolumn{16}{|c|}{$\begin{array}{c}\text { Ibagué batholith } \\
\text { CI2 }\end{array}$} \\
\hline $\mathrm{CI} 2$ & 0.282848 & 24 & 0.00051 & 2.6 & 0.01321 & 64 & 1.467138 & 32 & 1.886933 & 83 & 142.9 & 0.282847 & 2.2 & 0.8 & 5.4 \\
\hline $\mathrm{CI} 2$ & 0.282860 & 30 & 0.00121 & 4.4 & 0.03078 & 97 & 1.467145 & 38 & 1.886986 & 96 & 145.3 & 0.282857 & 2.7 & 1.1 & 5.8 \\
\hline CI2 & 0.282886 & 33 & 0.00119 & 2.7 & 0.03196 & 60 & 1.467149 & 29 & 1.886800 & 110 & 143.0 & 0.282883 & 3.6 & 1.2 & 6.6 \\
\hline CI2 & 0.282922 & 38 & 0.00227 & 8.1 & 0.05990 & 250 & 1.467178 & 34 & 1.886801 & 93 & 148.2 & 0.282916 & 4.8 & 1.3 & 7.9 \\
\hline CI2 & 0.282867 & 24 & 0.00081 & 4.4 & 0.02130 & 100 & 1.467124 & 31 & 1.886793 & 99 & 148.2 & 0.282865 & 2.9 & 0.8 & 6.1 \\
\hline CI2 & 0.282857 & 20 & 0.00095 & 1.2 & 0.02512 & 33 & 1.467142 & 34 & 1.886930 & 91 & 139.6 & 0.282855 & 2.5 & 0.7 & 5.6 \\
\hline CI2 & 0.282856 & 23 & 0.00131 & 9.9 & 0.03370 & 260 & $\begin{array}{l}1.467162 \\
\text { CI9B }\end{array}$ & 32 & 1.886920 & 110 & 148.0 & 0.282852 & 2.5 & 0.8 & 5.7 \\
\hline CI9B & 0.282867 & 23 & 0.00072 & 2.8 & 0.01916 & 81 & 1.467153 & 31 & 1.886876 & 87 & 142.1 & 0.282865 & 2.9 & 0.8 & 6.0 \\
\hline CI9B & 0.282860 & 23 & 0.00085 & 3.3 & 0.02263 & 92 & 1.467151 & 30 & 1.886931 & 77 & 141.9 & 0.282858 & 2.7 & 0.8 & 5.7 \\
\hline CI9B & 0.282860 & 29 & 0.00101 & 2.4 & 0.02689 & 49 & 1.467164 & 31 & 1.886925 & 91 & 141.5 & 0.282857 & 2.7 & 1.0 & 5.7 \\
\hline CI9B & 0.282856 & 26 & 0.00094 & 0.5 & 0.02513 & 11 & 1.467142 & 32 & 1.886968 & 98 & 140.7 & 0.282854 & 2.5 & 0.9 & 5.6 \\
\hline CI9B & 0.282836 & 29 & 0.00086 & 1.3 & 0.02347 & 34 & 1.467133 & 36 & 1.886960 & 110 & 142.1 & 0.282834 & 1.8 & 1.0 & 4.9 \\
\hline CI9B & 0.282832 & 29 & 0.00066 & 1.9 & 0.01751 & 60 & 1.467130 & 30 & 1.886970 & 100 & 144.3 & 0.282830 & 1.7 & 1.0 & 4.8 \\
\hline CI9B & 0.282872 & 26 & 0.00096 & 1.3 & 0.02599 & 22 & 1.467157 & 36 & 1.886968 & 88 & 142.1 & 0.282869 & 3.1 & 0.9 & 6.1 \\
\hline CI9B & 0.282850 & 23 & 0.00086 & 3.7 & 0.02260 & 110 & $\begin{array}{l}1.467147 \\
\text { CI11 }\end{array}$ & 24 & 1.886966 & 97 & 141.2 & 0.282848 & 2.3 & 0.8 & 5.4 \\
\hline CI11 & 0.282877 & 27 & 0.00055 & 1.9 & 0.01446 & 58 & 1.467143 & 37 & 1.886730 & 110 & 151.7 & 0.282875 & 3.3 & 1.0 & 6.6 \\
\hline
\end{tabular}




\begin{tabular}{|c|c|c|c|c|c|c|c|c|c|c|c|c|c|c|c|}
\hline CI11 & 0.282869 & 22 & 0.00073 & 3.4 & 0.01941 & 89 & 1.467165 & 33 & 1.886773 & 90 & 152.4 & 0.282867 & 3.0 & 0.8 & 6.3 \\
\hline CI11 & 0.282860 & 28 & 0.00074 & 1.7 & 0.02011 & 65 & 1.467137 & 30 & 1.886830 & 100 & 150.9 & 0.282858 & 2.7 & 1.0 & 5.9 \\
\hline CI11 & 0.282910 & 32 & 0.00065 & 1.2 & 0.01763 & 28 & 1.467133 & 36 & 1.886760 & 120 & 151.9 & 0.282908 & 4.4 & 1.1 & 7.7 \\
\hline CI11 & 0.282861 & 38 & 0.00081 & 2.8 & 0.02167 & 63 & 1.467188 & 29 & 1.886891 & 91 & 153.6 & 0.282859 & 2.7 & 1.3 & 6.0 \\
\hline CI11 & 0.282872 & 27 & 0.00056 & 1.9 & 0.01415 & 53 & 1.467141 & 20 & 1.886808 & 92 & 156.0 & 0.282870 & 3.1 & 1.0 & 6.5 \\
\hline CI11 & 0.282853 & 25 & 0.00031 & 1.0 & 0.00789 & 26 & 1.467150 & 33 & 1.886964 & 88 & 154.7 & 0.282852 & 2.4 & 0.9 & 5.8 \\
\hline CI11 & 0.282854 & 27 & 0.00076 & 0.5 & 0.02103 & 33 & $\begin{array}{l}1.467179 \\
\text { CI13 }\end{array}$ & 33 & 1.886940 & 93 & 149.3 & 0.282852 & 2.4 & 1.0 & 5.7 \\
\hline CI13 & 0.282882 & 24 & 0.00049 & 2.3 & 0.01331 & 65 & 1.467167 & 27 & 1.886910 & 79 & 147.6 & 0.282881 & 3.4 & 0.8 & 6.7 \\
\hline CI13 & 0.282871 & 46 & 0.00074 & 4.5 & 0.02070 & 120 & 1.467148 & 43 & 1.886860 & 170 & 141.6 & 0.282869 & 3.0 & 1.6 & 6.1 \\
\hline CI13 & 0.282864 & 28 & 0.00191 & 7.6 & 0.05490 & 240 & 1.467164 & 33 & 1.886910 & 79 & 147.3 & 0.282859 & 2.8 & 1.0 & 5.9 \\
\hline CI13 & 0.282865 & 30 & 0.00083 & 2.4 & 0.02274 & 70 & 1.467171 & 32 & 1.886956 & 93 & 142.3 & 0.282863 & 2.8 & 1.1 & 5.9 \\
\hline CI13 & 0.282818 & 37 & 0.00108 & 3.0 & 0.02937 & 66 & 1.467119 & 33 & 1.887130 & 140 & 145.1 & 0.282815 & 1.2 & 1.3 & 4.3 \\
\hline CI13 & 0.282812 & 42 & 0.00068 & 9.9 & 0.01800 & 280 & 1.467098 & 37 & 1.887060 & 140 & 140.3 & 0.282810 & 1.0 & 1.5 & 4.0 \\
\hline CI13 & 0.282853 & 41 & 0.00072 & 2.7 & 0.01902 & 72 & 1.467164 & 39 & 1.886950 & 130 & 144.3 & 0.282851 & 2.4 & 1.4 & 5.5 \\
\hline CI13 & 0.282865 & 21 & 0.00072 & 1.5 & 0.01941 & 49 & $\begin{array}{l}1.467131 \\
\text { CI15 }\end{array}$ & 31 & 1.886884 & 94 & 142.6 & 0.282863 & 2.8 & 0.7 & 5.9 \\
\hline CI15 & 0.282854 & 37 & 0.00067 & 2.6 & 0.01870 & 92 & 1.467165 & 33 & 1.886950 & 110 & 144.8 & 0.282852 & 2.4 & 1.3 & 5.6 \\
\hline CI15 & 0.282900 & 40 & 0.00087 & 1.0 & 0.02466 & 63 & 1.467185 & 36 & 1.886860 & 140 & 146.4 & 0.282898 & 4.1 & 1.4 & 7.2 \\
\hline CI15 & 0.282892 & 31 & 0.00087 & 1.4 & 0.02406 & 23 & 1.467158 & 35 & 1.886779 & 95 & 139.2 & 0.282890 & 3.8 & 1.1 & 6.8 \\
\hline CI15 & 0.282838 & 36 & 0.00064 & 1.6 & 0.01676 & 55 & 1.467155 & 29 & 1.886980 & 120 & 143.6 & 0.282836 & 1.9 & 1.3 & 5.0 \\
\hline CI15 & 0.282896 & 30 & 0.00082 & 2.2 & 0.02312 & 48 & 1.467175 & 36 & 1.886860 & 100 & 146.8 & 0.282894 & 3.9 & 1.1 & 7.1 \\
\hline CI15 & 0.282880 & 30 & 0.00073 & 2.8 & 0.01973 & 88 & 1.467181 & 26 & 1.886870 & 100 & 145.9 & 0.282878 & 3.4 & 1.1 & 6.5 \\
\hline CI15 & 0.282855 & 28 & 0.00046 & 0.8 & 0.01216 & 11 & 1.467186 & 32 & 1.886911 & 93 & 146.4 & 0.282854 & 2.5 & 1.0 & 5.7 \\
\hline CI15 & 0.282862 & 28 & 0.00030 & 1.1 & 0.00765 & 28 & 1.467159 & 33 & 1.886890 & 100 & 142.2 & 0.282861 & 2.7 & 1.0 & 5.9 \\
\hline CI15 & 0.282858 & 26 & 0.00063 & 0.6 & 0.01714 & 19 & 1.467145 & 27 & 1.886860 & 100 & 142.0 & 0.282856 & 2.6 & 0.9 & 5.7 \\
\hline CI15 & 0.282888 & 29 & 0.00052 & 0.2 & 0.01386 & 2 & 1.467172 & 30 & 1.886870 & 100 & 146.4 & 0.282887 & 3.6 & 1.0 & 6.8 \\
\hline \multicolumn{16}{|c|}{$\begin{array}{c}\text { Mariquita stock } \\
\text { CM4 }\end{array}$} \\
\hline CM4 & 0.282918 & 32 & 0.00150 & 3.8 & 0.03919 & 68 & 1.467151 & 37 & 1.886969 & 97 & 131.2 & 0.282914 & 4.7 & 1.1 & 7.5 \\
\hline CM4 & 0.282991 & 34 & 0.00215 & 21.0 & 0.05740 & 640 & 1.467155 & 37 & 1.886923 & 90 & 139.8 & 0.282985 & 7.3 & 1.2 & 10.2 \\
\hline CM4 & 0.282951 & 50 & 0.00234 & 17.0 & 0.06300 & 550 & 1.467120 & 40 & 1.886990 & 140 & 129.0 & 0.282945 & 5.9 & 1.8 & 8.5 \\
\hline CM4 & 0.282990 & 30 & 0.00149 & 2.4 & 0.03673 & 51 & 1.467167 & 40 & 1.886950 & 120 & 136.7 & 0.282986 & 7.2 & 1.1 & 10.2 \\
\hline CM4 & 0.282927 & 24 & 0.00152 & 1.7 & 0.04105 & 36 & 1.467150 & 36 & 1.887016 & 76 & 127.1 & 0.282923 & 5.0 & 0.8 & 7.7 \\
\hline CM4 & 0.282936 & 24 & 0.00161 & 7.5 & 0.04240 & 230 & 1.467145 & 38 & 1.887028 & 80 & 129.6 & 0.282932 & 5.3 & 0.8 & 8.1 \\
\hline CM4 & 0.282972 & 35 & 0.00176 & 7.9 & 0.04610 & 240 & 1.467140 & 46 & 1.886910 & 130 & 131.8 & 0.282968 & 6.6 & 1.2 & 9.4 \\
\hline CM4 & 0.282938 & 42 & 0.00298 & 9.3 & 0.07920 & 250 & $\begin{array}{l}1.467067 \\
\text { CM7 }\end{array}$ & 35 & 1.886960 & 130 & 124.2 & 0.282931 & 5.4 & 1.5 & 7.9 \\
\hline CM7 & 0.282972 & 27 & 0.00166 & 3.1 & 0.04460 & 100 & 1.467168 & 34 & 1.886872 & 96 & 131.2 & 0.282968 & 6.6 & 1.0 & 9.4 \\
\hline CM7 & 0.282975 & 35 & 0.00223 & 19.0 & 0.05870 & 520 & 1.467151 & 37 & 1.886890 & 97 & 127.3 & 0.282970 & 6.7 & 1.2 & 9.4 \\
\hline CM7 & 0.282926 & 45 & 0.00178 & 5.0 & 0.04610 & 130 & 1.467117 & 34 & 1.887070 & 150 & 130.9 & 0.282922 & 5.0 & 1.6 & 7.7 \\
\hline CM7 & 0.282933 & 28 & 0.00208 & 6.8 & 0.05440 & 180 & 1.467145 & 38 & 1.886909 & 87 & 133.9 & 0.282928 & 5.2 & 1.0 & 8.0 \\
\hline CM7 & 0.282947 & 69 & 0.00207 & 4.6 & 0.05900 & 160 & 1.467141 & 60 & 1.886950 & 230 & 129.5 & 0.282942 & 5.7 & 2.4 & 8.4 \\
\hline
\end{tabular}




\begin{tabular}{|c|c|c|c|c|c|c|c|c|c|c|c|c|c|c|c|}
\hline CM7 & 0.282885 & 38 & 0.00197 & 8.6 & 0.05230 & 230 & 1.467149 & 49 & 1.887030 & 130 & 128.3 & 0.282880 & 3.5 & 1.3 & 6.2 \\
\hline CM7 & 0.282938 & 33 & 0.00302 & 3.8 & 0.07850 & 120 & 1.467125 & 30 & 1.886990 & 110 & 131.1 & 0.282931 & 5.4 & 1.2 & 8.1 \\
\hline CM7 & 0.282886 & 46 & 0.00306 & 32.0 & 0.08570 & 930 & $\begin{array}{l}1.467111 \\
\text { CM10 }\end{array}$ & 51 & 1.887140 & 150 & 129.4 & 0.282879 & 3.6 & 1.6 & 6.2 \\
\hline CM10 & 0.282921 & 35 & 0.00135 & 6.6 & 0.03520 & 160 & 1.467120 & 39 & 1.886820 & 120 & 136.0 & 0.282918 & 4.8 & 1.2 & 7.7 \\
\hline CM10 & 0.283014 & 24 & 0.00203 & 5.2 & 0.04980 & 150 & 1.467174 & 30 & 1.886830 & 84 & 131.9 & 0.283009 & 8.1 & 0.8 & 10.9 \\
\hline CM10 & 0.282955 & 31 & 0.00170 & 2.3 & 0.04337 & 55 & 1.467125 & 35 & 1.886880 & 96 & 133.2 & 0.282951 & 6.0 & 1.1 & 8.8 \\
\hline CM10 & 0.282931 & 26 & 0.00211 & 6.8 & 0.05570 & 200 & 1.467175 & 30 & 1.886883 & 80 & 131.5 & 0.282926 & 5.2 & 0.9 & 7.9 \\
\hline CM10 & 0.283049 & 78 & 0.00111 & 5.8 & 0.02810 & 160 & 1.467181 & 82 & 1.886440 & 220 & 131.8 & 0.283046 & 9.3 & 2.8 & 12.2 \\
\hline CM10 & 0.282896 & 48 & 0.00159 & 6.3 & 0.04050 & 140 & 1.467124 & 37 & 1.886900 & 150 & 132.9 & 0.282892 & 3.9 & 1.7 & 6.7 \\
\hline CM10 & 0.282982 & 31 & 0.00138 & 4.2 & 0.03382 & 85 & 1.467134 & 32 & 1.886768 & 90 & 135.2 & 0.282979 & 7.0 & 1.1 & 9.8 \\
\hline CM10 & 0.283010 & 31 & 0.00175 & 5.4 & 0.04110 & 130 & $\begin{array}{l}1.467152 \\
\text { CM17B }\end{array}$ & 32 & 1.886800 & 110 & 136.4 & 0.283006 & 8.0 & 1.1 & 10.8 \\
\hline CM17B & 0.282911 & 26 & 0.00155 & 5.1 & 0.04230 & 140 & 1.467165 & 32 & 1.886889 & 84 & 133.2 & 0.282907 & 4.5 & 0.9 & 7.3 \\
\hline CM17B & 0.282948 & 22 & 0.00154 & 2.1 & 0.04072 & 57 & 1.467140 & 20 & 1.886911 & 80 & 128.1 & 0.282944 & 5.8 & 0.8 & 8.5 \\
\hline CM17B & 0.282961 & 35 & 0.00173 & 18.0 & 0.04770 & 580 & 1.467164 & 38 & 1.886880 & 100 & 132.4 & 0.282957 & 6.2 & 1.2 & 9.0 \\
\hline CM17B & 0.282902 & 28 & 0.00194 & 1.2 & 0.05319 & 66 & 1.467138 & 36 & 1.886828 & 82 & 130.9 & 0.282897 & 4.1 & 1.0 & 6.9 \\
\hline CM17B & 0.282954 & 32 & 0.00186 & 5.2 & 0.05240 & 170 & 1.467132 & 30 & 1.886906 & 99 & 134.4 & 0.282949 & 6.0 & 1.1 & 8.8 \\
\hline CM17B & 0.282937 & 32 & 0.00225 & 11.0 & 0.06210 & 410 & 1.467111 & 50 & 1.886960 & 120 & 133.0 & 0.282931 & 5.4 & 1.1 & 8.1 \\
\hline CM17B & 0.282910 & 37 & 0.00176 & 4.7 & 0.04380 & 150 & 1.467114 & 37 & 1.887030 & 100 & 130.0 & 0.282906 & 4.4 & 1.3 & 7.2 \\
\hline CM17B & 0.282907 & 30 & 0.00162 & 3.2 & 0.04451 & 75 & $\begin{array}{l}1.467142 \\
\text { CM19 }\end{array}$ & 38 & 1.886960 & 110 & 135.3 & 0.282903 & 4.3 & 1.1 & 7.2 \\
\hline CM19 & 0.283039 & 49 & 0.00236 & 12.0 & 0.06290 & 350 & 1.467159 & 48 & 1.886730 & 170 & 125.5 & 0.283033 & 9.0 & 1.7 & 11.6 \\
\hline CM19 & 0.282920 & 75 & 0.00134 & 6.3 & 0.03480 & 150 & 1.467116 & 64 & 1.887000 & 250 & 135.0 & 0.282917 & 4.8 & 2.7 & 7.7 \\
\hline CM19 & 0.282879 & 60 & 0.00311 & 16.0 & 0.09010 & 610 & 1.467119 & 43 & 1.887170 & 190 & 130.1 & 0.282871 & 3.3 & 2.1 & 5.9 \\
\hline CM19 & 0.282982 & 65 & 0.00248 & 25.0 & 0.06580 & 750 & 1.467178 & 41 & 1.886870 & 190 & 133.3 & 0.282976 & 7.0 & 2.3 & 9.7 \\
\hline CM19 & 0.282998 & 43 & 0.00192 & 5.2 & 0.05020 & 170 & 1.467157 & 39 & 1.886760 & 120 & 130.2 & 0.282993 & 7.5 & 1.5 & 10.3 \\
\hline CM19 & 0.282969 & 40 & 0.00244 & 15.0 & 0.07160 & 480 & 1.467163 & 38 & 1.886900 & 120 & 126.7 & 0.282963 & 6.5 & 1.4 & 9.1 \\
\hline CM19 & 0.282945 & 30 & 0.00131 & 3.3 & 0.03575 & 84 & 1.467165 & 33 & 1.886826 & 95 & 135.2 & 0.282942 & 5.7 & 1.1 & 8.5 \\
\hline CM19 & 0.282995 & 60 & 0.00191 & 10.0 & 0.05180 & 300 & 1.467139 & 43 & 1.886810 & 180 & 130.0 & 0.282990 & 7.4 & 2.1 & 10.2 \\
\hline
\end{tabular}


Table 3.3. Geochemistry of major, trace and rare earth elements of the Payandé, Ibagué and Mariquita plutons.

\begin{tabular}{|c|c|c|c|c|c|c|c|c|c|c|c|c|c|c|c|c|c|c|c|c|c|c|c|}
\hline Sample & CSP3 & CSP5 & $\mathrm{CI} 2$ & CI5B & $\mathrm{CI} 7$ & CI9B & CI10 & CI11A & CI13 & CI15 & $\mathrm{CM} 2$ & CM4 & CM6 & CM7 & CM8 & CM10 & CM11 & CM13 & CM14 & CM17C & CM19 & CM21B & CM22A \\
\hline $\mathrm{SiO}_{2}$ & 67.70 & 67.90 & 67.84 & 64.32 & 63.66 & 57.80 & 57.19 & 61.20 & 61.70 & 58.91 & 71.13 & 71.00 & 70.99 & 75.07 & 73.20 & 73.35 & 73.14 & 72.27 & 71.74 & 70.40 & 73.60 & 68.00 & 68.87 \\
\hline $\mathrm{Al} 2 \mathrm{O} 3$ & 15.19 & 14.85 & 15.59 & 15.78 & 17.91 & 17.88 & 17.18 & 16.06 & 16.35 & 16.79 & 14.50 & 14.74 & 14.46 & 13.57 & 13.22 & 14.28 & 13.70 & 14.32 & 14.87 & 14.97 & 13.94 & 15.16 & 15.20 \\
\hline $\mathrm{Fe}_{2} \mathrm{O}_{3}$ & 3.54 & 3.51 & 3.56 & 4.75 & 4.63 & 6.86 & 6.67 & 6.25 & 5.45 & 6.00 & 2.69 & 2.85 & 2.59 & 1.68 & 1.98 & 2.13 & 1.93 & 2.45 & 2.20 & 3.02 & 2.12 & 3.54 & 3.22 \\
\hline $\mathrm{MgO}$ & 2.05 & 2.19 & 1.37 & 2.06 & 1.82 & 3.93 & 4.19 & 3.61 & 3.02 & 3.70 & 1.09 & 0.95 & 1.14 & 0.38 & 0.72 & 0.78 & 0.67 & 0.87 & 0.92 & 1.13 & 0.69 & 1.78 & 1.32 \\
\hline $\mathrm{MnO}$ & 0.07 & 0.07 & 0.04 & 0.10 & 0.09 & 0.12 & 0.13 & 0.11 & 0.10 & 0.12 & 0.06 & 0.06 & 0.07 & 0.04 & 0.05 & 0.05 & 0.04 & 0.05 & 0.05 & 0.06 & 0.06 & 0.07 & 0.06 \\
\hline $\mathrm{CaO}$ & 3.73 & 3.78 & 3.35 & 3.97 & 5.93 & 7.15 & 5.35 & 6.05 & 5.43 & 6.66 & 3.26 & 3.09 & 3.25 & 1.75 & 2.18 & 2.69 & 2.34 & 2.94 & 3.01 & 3.36 & 2.38 & 4.25 & 3.73 \\
\hline $\mathrm{K}_{2} \mathrm{O}$ & 2.37 & 2.69 & 2.31 & 1.93 & 1.32 & 0.84 & 1.08 & 1.97 & 1.83 & 1.38 & 2.19 & 2.19 & 2.07 & 2.87 & 2.97 & 2.26 & 3.02 & 2.25 & 2.41 & 2.12 & 2.22 & 1.77 & 1.87 \\
\hline $\mathrm{Na}_{2} \mathrm{O}$ & 3.85 & 3.63 & 4.14 & 4.68 & 3.68 & 4.04 & 4.31 & 3.92 & 3.81 & 3.60 & 3.82 & 4.34 & 4.00 & 4.28 & 3.59 & 3.94 & 3.67 & 3.98 & 4.10 & 4.11 & 4.14 & 4.15 & 3.83 \\
\hline $\mathrm{P}_{2} \mathrm{O}_{5}$ & 0.10 & 0.10 & 0.12 & 0.14 & 0.14 & 0.17 & 0.17 & 0.22 & 0.13 & 0.16 & 0.11 & 0.12 & 0.10 & 0.05 & 0.08 & 0.10 & 0.08 & 0.11 & 0.08 & 0.12 & 0.07 & 0.11 & 0.17 \\
\hline $\mathrm{TiO}_{2}$ & 0.42 & 0.43 & 0.48 & 0.61 & 0.50 & 0.82 & 0.86 & 0.72 & 0.67 & 0.75 & 0.43 & 0.49 & 0.41 & 0.23 & 0.31 & 0.32 & 0.32 & 0.39 & 0.34 & 0.48 & 0.31 & 0.51 & 0.53 \\
\hline LOI & 1.23 & 0.90 & 1.48 & 2.23 & 0.61 & 0.79 & 2.16 & 0.55 & 1.25 & 0.78 & 0.46 & 0.72 & 0.60 & 0.46 & 0.57 & 0.59 & 0.47 & 0.38 & 0.33 & 0.35 & 0.61 & 1.12 & 0.73 \\
\hline SUM & 100.3 & 100.1 & 98.8 & 98.3 & 99.7 & 100.4 & 97.1 & 100.7 & 99.8 & 98.1 & 99.3 & 100.6 & 99.1 & 99.9 & 98.3 & 99.9 & 98.9 & 99.6 & 99.7 & 100.1 & 100.1 & 100.5 & 98.8 \\
\hline $\mathrm{Ba}$ & 636.0 & 608.0 & 488.5 & 525.8 & 674.2 & 318.0 & 285.5 & 804.0 & 475.0 & 292.2 & 446.7 & 389.0 & 328.8 & 372.8 & 476.5 & 406.8 & 543.9 & 410.7 & 515.2 & 405.0 & 358.0 & 252.0 & 382.5 \\
\hline $\mathrm{Ce}$ & 30.0 & 44.8 & 47.3 & 36.1 & 25.2 & 27.4 & 39.2 & 49.8 & 44.9 & 33.6 & 49.3 & 40.8 & 32.0 & 37.1 & 41.9 & 27.7 & 48.7 & 30.1 & 29.5 & 56.2 & 36.5 & 28.7 & 36.3 \\
\hline $\mathrm{Ga}$ & 14.7 & 14.0 & 17.4 & 16.8 & 18.8 & 17.9 & 17.7 & 17.8 & 16.6 & 18.9 & 16.7 & 14.9 & 15.1 & 14.9 & 14.9 & 15.4 & 15.6 & 16.5 & 16.1 & 14.4 & 13.6 & 14.8 & 17.3 \\
\hline $\mathrm{La}$ & 16.2 & 26.6 & 24.4 & 19.0 & 12.7 & 12.8 & 16.0 & 23.5 & 18.8 & 13.4 & 23.0 & 20.1 & 17.7 & 18.6 & 25.1 & 13.1 & 25.6 & 13.7 & 15.6 & 28.6 & 19.1 & 14.0 & 15.4 \\
\hline $\mathrm{Nb}$ & 5.8 & 5.8 & 7.6 & 8.6 & 4.9 & 6.0 & 7.6 & 5.9 & 8.0 & 7.3 & 7.0 & 6.4 & 6.0 & 6.3 & 6.4 & 6.0 & 6.4 & 6.4 & 5.9 & 6.2 & 4.5 & 4.0 & 7.3 \\
\hline $\mathrm{Nd}$ & 12.5 & 14.5 & 21.9 & 19.6 & 9.9 & 13.8 & 21.9 & 21.7 & 26.1 & 16.7 & 21.8 & 19.0 & 15.9 & 18.9 & 20.3 & 12.4 & 21.5 & 13.3 & 14.4 & 24.9 & 14.5 & 13.1 & 16.1 \\
\hline $\mathrm{Rb}$ & 66.4 & 63.0 & 45.3 & 43.6 & 52.3 & 12.2 & 21.7 & 43.7 & 41.0 & 36.0 & 91.0 & 80.2 & 92.0 & 121.5 & 125.6 & 97.1 & 119.9 & 91.3 & 101.5 & 80.5 & 85.2 & 57.5 & 81.9 \\
\hline $\mathrm{Sr}$ & 366.3 & 351.5 & 305.6 & 514.4 & 420.5 & 503.6 & 438.8 & 704.0 & 458.0 & 402.4 & 127.4 & 139.7 & 119.2 & 86.7 & 83.5 & 118.2 & 99.0 & 127.9 & 149.8 & 154.1 & 112.3 & 144.7 & 153.5 \\
\hline Th & 10.1 & 14.5 & 6.5 & 8.8 & 4.5 & 1.3 & 3.2 & 3.3 & 8.3 & 5.1 & 6.4 & 7.6 & 6.4 & 8.9 & 8.9 & 4.9 & 7.3 & 9.5 & 5.8 & 7.7 & 6.2 & 4.3 & 3.0 \\
\hline $\mathrm{U}$ & 2.2 & 3.8 & 3.0 & 2.7 & 0.0 & 0.3 & 0.0 & 0.9 & 5.0 & 1.4 & 3.0 & 3.6 & 2.8 & 2.8 & 3.7 & 3.8 & 4.2 & 3.7 & 3.0 & 2.8 & 2.6 & 2.3 & 2.4 \\
\hline V & 63.0 & 65.0 & 75.7 & 101.4 & 63.6 & 172.0 & 178.3 & 172.0 & 138.0 & 166.5 & 41.4 & 39.0 & 42.5 & 15.5 & 26.6 & 33.7 & 29.9 & 33.7 & 34.0 & 38.0 & 25.0 & 64.0 & 49.3 \\
\hline $\mathrm{Y}$ & 13.0 & 11.1 & 18.8 & 23.5 & 12.2 & 17.3 & 29.5 & 18.6 & 31.3 & 24.2 & 30.7 & 31.3 & 26.8 & 32.7 & 30.4 & 24.3 & 22.8 & 26.9 & 23.1 & 24.5 & 22.4 & 24.3 & 25.5 \\
\hline $\mathrm{Zr}$ & 114.7 & 108.7 & 166.9 & 202.0 & 134.0 & 112.5 & 182.0 & 182.1 & 151.0 & 130.6 & 178.2 & 225.1 & 190.9 & 151.4 & 143.4 & 163.7 & 146.6 & 183.8 & 134.9 & 189.7 & 154.2 & 144.7 & 231.9 \\
\hline $\mathrm{Cu}$ & 2.4 & 1.8 & 5.9 & 3.3 & 6.6 & 23.9 & 36.6 & 63.9 & 52.6 & 27.3 & 7.8 & 8.9 & 8.1 & 1.2 & 4.4 & 7.0 & 7.3 & 3.5 & 3.6 & 8.7 & 2.4 & 8.8 & 4.8 \\
\hline $\mathrm{Ni}$ & 14.9 & 13.7 & 2.2 & 7.1 & 4.3 & 10.1 & 11.5 & 10.3 & 7.3 & 13.5 & 3.8 & 2.6 & 8.4 & 1.6 & 3.5 & 2.7 & 4.2 & 4.4 & 3.8 & 3.7 & 1.9 & 4.8 & 5.4 \\
\hline $\mathrm{Pb}$ & 2.0 & 2.1 & 4.2 & 2.5 & 5.9 & 0.4 & 4.6 & 1.3 & 2.3 & 6.7 & 10.4 & 3.5 & 8.8 & 10.7 & 13.8 & 12.5 & 13.5 & 11.6 & 11.9 & 1.7 & 2.7 & 2.3 & 8.9 \\
\hline $\mathrm{Zn}$ & 23.0 & 26.0 & 17.2 & 37.0 & 71.3 & 22.0 & 79.4 & 37.0 & 32.0 & 72.6 & 61.3 & 46.0 & 53.4 & 32.6 & 48.6 & 51.0 & 46.9 & 51.7 & 51.5 & 47.0 & 38.0 & 35.0 & 66.8 \\
\hline
\end{tabular}


Table 3.4. Whole rock $\mathrm{Nd}, \mathrm{Pb}$ and $\mathrm{Hf}$ isotopic analyses of the Payandé, Ibagué and Mariquita plutons.

\begin{tabular}{cccccccc}
\hline Sample & $\mathrm{U}-\mathrm{Pb}$ Age $(\mathrm{Ma})$ & ${ }^{143} \mathrm{Nd} /{ }^{144} \mathrm{Nd}(\mathrm{pd})$ & $2 \mathrm{SE}$ & ${ }^{143} \mathrm{Nd} /{ }^{144} \mathrm{Nd}(\mathrm{i})$ & $\varepsilon_{\mathrm{Nd}}(\mathrm{pd})$ & $2 \mathrm{SE}$ & $\varepsilon_{\mathrm{Nd}}(\mathrm{i})$ \\
\hline $\mathrm{CM} 19$ & 130 & 0.512864 & 0.000006 & 0.512750 & 4.6 & 0.12 & 5.6 \\
$\mathrm{CM} 4$ & 132 & 0.512800 & 0.000006 & 0.512670 & 3.3 & 0.12 & 4.1 \\
$\mathrm{CM} 8$ & 130 & 0.512755 & 0.000006 & 0.512641 & 2.4 & 0.11 & 3.5 \\
CI7 & 140 & 0.512600 & 0.000006 & 0.512490 & -0.6 & 0.12 & 0.8 \\
CI9B & 142 & 0.512795 & 0.000006 & 0.512664 & 3.2 & 0.12 & 4.2 \\
CI11A & 152 & 0.512747 & 0.000006 & 0.512626 & 2.3 & 0.12 & 3.7 \\
CSP5 & 165 & 0.512649 & 0.000008 & 0.512532 & 0.4 & 0.15 & 2.2 \\
\hline
\end{tabular}

\begin{tabular}{ccccccccccccccc}
\hline Sample & $\begin{array}{c}\mathrm{U}-\mathrm{Pb} \mathrm{Age} \\
(\mathrm{Ma})\end{array}$ & ${ }^{206} \mathrm{~Pb} /{ }^{204} \mathrm{~Pb}$ & \multicolumn{3}{c}{${ }^{207} \mathrm{~Pb} /{ }^{204} \mathrm{~Pb}$} & \multicolumn{3}{c}{${ }^{208} \mathrm{~Pb} /{ }^{204} \mathrm{~Pb}$} & \multicolumn{3}{c}{${ }^{207} \mathrm{~Pb} /{ }^{206} \mathrm{~Pb}$} & & ${ }^{208} \mathrm{~Pb} /{ }^{206} \mathrm{~Pb}$ & \\
\hline $\mathrm{CM} 19$ & 130 & 18.84 & \pm 0.0106 & 15.61 & \pm 0.0231 & 38.37 & \pm 0.0360 & 0.828362 & 0.000838 & 2.03672 & \pm 0.00082 \\
$\mathrm{CM} 4$ & 132 & 18.72 & \pm 0.0106 & 15.61 & \pm 0.0231 & 38.52 & \pm 0.0361 & 0.833981 & 0.000837 & 2.05774 & \pm 0.00082 \\
$\mathrm{CM} 8$ & 130 & 18.70 & \pm 0.0106 & 15.61 & \pm 0.0231 & 38.56 & \pm 0.0361 & 0.834626 & 0.000837 & 2.06171 & \pm 0.00082 \\
CI7 & 140 & 18.60 & \pm 0.0106 & 15.62 & \pm 0.0231 & 39.10 & \pm 0.0360 & 0.839596 & 0.000838 & 2.10197 & \pm 0.00082 \\
CI9B & 142 & 18.50 & \pm 0.0106 & 15.59 & \pm 0.0231 & 38.28 & \pm 0.0362 & 0.842394 & 0.000837 & 2.06895 & \pm 0.00082 \\
C11A & 152 & 18.71 & \pm 0.0106 & 15.60 & \pm 0.0231 & 38.53 & \pm 0.0361 & 0.833419 & 0.000837 & 2.05900 & \pm 0.00082 \\
CSP5 & 165 & 18.80 & \pm 0.0106 & 15.62 & \pm 0.0231 & 38.55 & \pm 0.0361 & 0.830961 & 0.000837 & 2.05082 & \pm 0.00082 \\
\hline
\end{tabular}

\begin{tabular}{|c|c|c|c|c|c|c|c|c|c|c|c|c|c|c|c|}
\hline Sample & $\begin{array}{l}\text { U-Pb Age } \\
\text { (Ma) }\end{array}$ & $\begin{array}{c}\mathrm{Lu} \\
(\mathrm{ppm})\end{array}$ & $\begin{array}{c}\mathrm{Hf} \\
(\mathrm{ppm})\end{array}$ & ${ }^{175} \mathrm{Lu}$ & ${ }^{176} \mathrm{Hf}$ & ${ }^{176} \mathrm{Lu} /{ }^{175} \mathrm{Lu}$ & ${ }^{176} \mathrm{Lu} /{ }^{177} \mathrm{Hf}$ & ${ }^{176} \mathrm{Yb} /{ }^{177} \mathrm{Hf}$ & ${ }^{176} \mathrm{Lu} /{ }^{177} \mathrm{Hf}$ & ${ }^{176} \mathrm{Hf} /{ }^{177} \mathrm{Hf}$ & err & $\varepsilon_{\mathrm{Hf}(\mathrm{pd})}$ & $2 \mathrm{SE}$ & $\varepsilon_{\mathrm{Hf(i)}}$ & $2 \mathrm{SE}$ \\
\hline CM19 & 130 & 0.367 & 4.334 & 1.45 & 1.32 & 0.416365 & 0.000001 & 0.000001 & 0.012003 & 0.283032 & 0.000004 & 8.75 & 0.14 & 10.61 & 0.14 \\
\hline CM4 & 132 & 0.489 & 5.677 & 1.88 & 1.33 & 0.337066 & 0.000002 & 0.000001 & 0.012210 & 0.283001 & 0.000004 & 7.65 & 0.15 & 9.52 & 0.15 \\
\hline CM8 & 130 & 0.455 & 4.094 & 3.06 & 1.24 & 0.312949 & 0.000058 & 0017 & 0.015769 & 2948 & 0.000005 & 5.76 & 0.16 & 7.29 & 0.16 \\
\hline $\mathrm{CI} 7$ & 140 & 0.164 & 2.835 & 0.96 & 1.27 & 0.595604 & 0.000005 & 0.000004 & 0.008186 & 0.282843 & 0.000004 & 2.07 & 0.16 & 4.42 & 0.16 \\
\hline CI9B & 142 & 0.266 & 2.070 & 1.06 & 1.31 & 0.345096 & 0.000001 & 0.000002 & 0.018217 & 0.282968 & 0.000004 & 6.47 & 0.15 & 7.92 & 0.15 \\
\hline CI11A & 152 & 0.256 & 2.074 & 1.84 & 1.20 & 0.272092 & 0.000023 & 0.000020 & 0.017500 & 0.282955 & 0.000004 & 6.01 & 0.16 & 7.63 & 0.16 \\
\hline CSP5 & 165 & 0.195 & 2.997 & 0.80 & 1.39 & 0.586801 & 0.000071 & 0.000011 & 0.009248 & 0.282820 & 0.000004 & 1.24 & 0.13 & 3.90 & 0.13 \\
\hline
\end{tabular}


Table 4.1. Whole rock geochemistry and $\mathrm{Sr}, \mathrm{Nd}$ and $\mathrm{Pb}$ isotopes from the Hatillo and $\mathrm{El}$ Bosque plutons.

\begin{tabular}{|c|c|c|c|c|c|c|c|c|c|c|c|c|c|c|}
\hline & $\mathrm{CH} 2$ & CH6A & $\mathrm{CH} 9$ & $\mathrm{CH} 12$ & $\mathrm{CH} 14$ & CH15 & $\mathrm{CH} 10$ & CH8 & $\mathrm{CH} 19$ & $\mathrm{CH} 20$ & $\mathrm{CH} 21 \mathrm{~B}$ & $\mathrm{CH} 5$ & CB1 & CB2 \\
\hline $\mathrm{SiO} 2$ & 66.39 & 65.85 & 66.28 & 65.83 & 65.85 & 65.94 & 65.80 & 65.31 & 67.20 & 67.20 & 67.20 & 65.30 & 68.50 & 67.96 \\
\hline $\mathrm{TiO} 2$ & 0.54 & 0.54 & 0.54 & 0.54 & 0.52 & 0.50 & 0.50 & 0.580 & 0.52 & 0.49 & 0.44 & 0.57 & 0.42 & 0.44 \\
\hline $\mathrm{Al} 2 \mathrm{O} 3$ & 16.63 & 17.10 & 16.75 & 16.92 & 16.77 & 16.69 & 16.61 & 17.29 & 16.80 & 16.63 & 15.93 & 16.86 & 16.48 & 16.47 \\
\hline $\mathrm{FeOt}$ & 3.47 & 3.50 & 3.53 & 3.47 & 3.47 & 3.26 & 3.42 & 3.66 & 3.10 & 3.06 & 2.90 & 3.54 & 2.41 & 2.49 \\
\hline $\mathrm{MnO}$ & 0.07 & 0.07 & 0.07 & 0.07 & 0.07 & 0.06 & 0.07 & 0.077 & 0.06 & 0.06 & 0.06 & 0.07 & 0.05 & 0.05 \\
\hline $\mathrm{MgO}$ & 1.95 & 2.01 & 2.02 & 1.93 & 1.93 & 1.81 & 2.09 & 2.09 & 1.76 & 2.01 & 1.94 & 2.21 & 1.10 & 0.99 \\
\hline $\mathrm{CaO}$ & 4.48 & 4.72 & 4.60 & 4.88 & 4.68 & 4.52 & 4.89 & 4.87 & 4.34 & 4.46 & 3.99 & 4.98 & 3.52 & 2.98 \\
\hline $\mathrm{Na} 2 \mathrm{O}$ & 4.01 & 4.17 & 3.88 & 4.05 & 3.98 & 4.09 & 4.01 & 4.18 & 4.20 & 4.28 & 4.23 & 4.05 & 3.38 & 3.32 \\
\hline $\mathrm{K} 2 \mathrm{O}$ & 1.54 & 1.39 & 1.67 & 1.48 & 1.53 & 1.56 & 1.46 & 1.77 & 1.74 & 1.60 & 1.72 & 1.52 & 2.53 & 2.20 \\
\hline $\mathrm{P} 2 \mathrm{O} 5$ & 0.18 & 0.17 & 0.17 & 0.19 & 0.18 & 0.17 & 0.16 & 0.181 & 0.18 & 0.15 & 0.14 & 0.19 & 0.14 & 0.14 \\
\hline Sum & 99.2 & 99.5 & 99.5 & 99.4 & 99.0 & 98.6 & 99.0 & 100.0 & 100.9 & 101.0 & 100.0 & 100.4 & 100.2 & 97.0 \\
\hline LOI & 1.38 & 0.77 & 0.65 & 0.56 & 0.72 & 0.68 & 0.38 & 0.53 & 0.62 & 0.66 & 1.05 & 0.61 & 1.30 & 1.98 \\
\hline $\mathrm{La}$ & 27.55 & 19.40 & 19.17 & 21.95 & 20.24 & 24.27 & 22.59 & 16.95 & 25.30 & 16.90 & 22.40 & 19.50 & 40.80 & 25.62 \\
\hline $\mathrm{Ce}$ & 52.07 & 38.30 & 38.40 & 43.25 & 40.25 & 47.25 & 43.22 & 34.23 & 50.40 & 32.60 & 45.20 & 38.50 & 71.60 & 46.40 \\
\hline $\operatorname{Pr}$ & 6.52 & 4.85 & 4.76 & 5.43 & 5.11 & 5.72 & 5.20 & 4.46 & 5.70 & 4.08 & 5.23 & 4.83 & 8.67 & 5.82 \\
\hline $\mathrm{Nd}$ & 25.00 & 18.96 & 18.74 & 21.01 & 20.32 & 22.03 & 19.37 & 18.48 & 21.70 & 19.60 & 20.20 & 16.40 & 31.40 & 21.36 \\
\hline $\mathrm{Sm}$ & 4.86 & 3.83 & 4.04 & 4.19 & 4.29 & 4.09 & 3.66 & 4.18 & 4.12 & 3.35 & 4.07 & 3.55 & 5.46 & 4.19 \\
\hline $\mathrm{Eu}$ & 1.38 & 1.16 & 1.16 & 1.22 & 1.27 & 1.19 & 1.08 & 1.25 & 1.07 & 0.93 & 0.98 & 1.08 & 1.22 & 1.16 \\
\hline $\mathrm{Gd}$ & 4.00 & 3.18 & 3.36 & 3.59 & 3.53 & 3.25 & 2.96 & 3.56 & 3.31 & 2.72 & 3.39 & 3.06 & 4.45 & 3.24 \\
\hline $\mathrm{Tb}$ & 0.60 & 0.46 & 0.50 & 0.52 & 0.54 & 0.49 & 0.43 & 0.53 & 0.40 & 0.37 & 0.50 & 0.44 & 0.61 & 0.45 \\
\hline Dy & 3.38 & 2.59 & 2.80 & 2.86 & 3.11 & 2.71 & 2.38 & 3.02 & 2.27 & 2.05 & 2.69 & 2.87 & 2.52 & 2.10 \\
\hline Но & 0.64 & 0.49 & 0.52 & 0.54 & 0.60 & 0.51 & 0.45 & 0.57 & 0.40 & 0.39 & 0.57 & 0.48 & 0.44 & 0.34 \\
\hline $\mathrm{Er}$ & 1.61 & 1.27 & 1.39 & 1.41 & 1.54 & 1.37 & 1.14 & 1.50 & 1.00 & 1.01 & 1.49 & 1.27 & 1.13 & 0.81 \\
\hline $\mathrm{Tm}$ & 0.23 & 0.18 & 0.20 & 0.20 & 0.22 & 0.20 & 0.17 & 0.22 & 0.13 & 0.16 & 0.21 & 0.18 & 0.12 & 0.10 \\
\hline $\mathrm{Yb}$ & 1.44 & 1.16 & 1.23 & 1.25 & 1.39 & 1.27 & 1.05 & 1.35 & 0.86 & 0.88 & 1.47 & 1.22 & 0.97 & 0.65 \\
\hline $\mathrm{Lu}$ & 0.22 & 0.18 & 0.19 & 0.20 & 0.21 & 0.20 & 0.17 & 0.21 & 0.14 & 0.14 & 0.20 & 0.19 & 0.14 & 0.10 \\
\hline $\mathrm{Ba}$ & 710.82 & 631.62 & 745.41 & 682.92 & 813.50 & 766.04 & 683.10 & 758 & 833.00 & 720.00 & 696.00 & 768.00 & 1004.00 & 893.95 \\
\hline Th & 6.12 & 4.25 & 4.83 & 5.20 & 5.24 & 7.17 & 4.56 & 4.87 & 5.40 & 3.60 & 7.50 & 4.20 & 11.20 & 7.51 \\
\hline $\mathrm{Nb}$ & 5.31 & 4.80 & 5.24 & 5.12 & 5.12 & 5.01 & 4.41 & 6.97 & 4.90 & 4.10 & 5.80 & 4.20 & 7.60 & 6.48 \\
\hline $\mathrm{Y}$ & 16.62 & 12.89 & 14.00 & 14.40 & 14.75 & 13.45 & 11.47 & 15.40 & 11.70 & 10.70 & 14.70 & 13.20 & 13.30 & 9.03 \\
\hline $\mathrm{Hf}$ & 3.65 & 3.44 & 3.13 & 3.39 & 3.72 & 3.71 & 3.30 & 3.71 & 3.00 & 3.20 & 2.80 & 3.40 & 3.90 & 3.67 \\
\hline $\mathrm{Ta}$ & 0.51 & 0.34 & 0.41 & 0.40 & 0.53 & 0.49 & 0.42 & 0.56 & 0.30 & 0.30 & 0.40 & 0.30 & 0.70 & 0.56 \\
\hline $\mathrm{U}$ & 1.98 & 1.51 & 2.36 & 2.75 & 2.65 & 2.26 & 1.45 & 2.10 & 2.50 & 1.60 & 2.00 & 1.80 & 1.60 & 2.66 \\
\hline $\mathrm{Pb}$ & 8.93 & 8.38 & 8.85 & 9.32 & 9.63 & 8.13 & 7.26 & 9.47 & 25.20 & 0.60 & 0.60 & 0.60 & 1.80 & 14.64 \\
\hline $\mathrm{Rb}$ & 44.24 & 38.46 & 59.84 & 42.89 & 46.85 & 43.08 & 38.13 & 49.2 & 48.60 & 47.00 & 43.40 & 38.00 & 86.60 & 92.77 \\
\hline Cs & 2.10 & 1.89 & 2.68 & 1.81 & 2.57 & 1.84 & 1.77 & 2.30 & 2.30 & 1.60 & 3.10 & 2.00 & 5.00 & 9.13 \\
\hline
\end{tabular}




\begin{tabular}{|c|c|c|c|c|c|c|c|c|c|c|c|c|c|c|}
\hline $\mathrm{Sr}$ & 570.9 & 576.1 & 551.4 & 600.2 & 566.5 & 558.0 & 551.1 & 579.3 & 647.9 & 589.9 & 568.8 & 625.6 & 377.3 & 304.6 \\
\hline $\mathrm{Sc}$ & 9.50 & 9.77 & 9.86 & 9.93 & 9.42 & 9.24 & 9.94 & 10.3 & & & & & & 5.26 \\
\hline $\mathrm{Zr}$ & 134.54 & 130.81 & 115.89 & 126.89 & 134.22 & 131.86 & 119.64 & 137 & 130.30 & 116.70 & 102.20 & 138.30 & 131.70 & 134.37 \\
\hline Sm (ppm) & & & 3.64 & & & & 3.02 & & & & 3.61 & 3.66 & 5.06 & \\
\hline $\mathrm{Nd}(\mathrm{ppm})$ & & & 18.36 & & & & 15.74 & & & & 17.41 & 18.34 & 27.74 & \\
\hline${ }^{147} \mathrm{Sm} /{ }^{144} \mathrm{Nd}$ & & & 0.1199 & & & & 0.1161 & & & & 0.1254 & 0.1205 & 0.1104 & \\
\hline${ }^{143} \mathrm{Nd} /{ }^{144} \mathrm{Nd}(\mathrm{pd})$ & & & 0.512657 & & & & 0.512653 & & & & 0.512694 & 0.512646 & 0.512497 & \\
\hline 2SE & & & 0.000006 & & & & 0.000006 & & & & 0.000010 & 0.000006 & 0.000007 & \\
\hline${ }^{143} \mathrm{Nd} /{ }^{144} \mathrm{Nd}(\mathrm{i})$ & & & 0.512614 & & & & 0.512612 & & & & 0.512648 & 0.512604 & 0.512455 & \\
\hline$\varepsilon_{\mathrm{Nd}(\mathrm{pd})}$ & & & 0.52 & & & & 0.46 & & & & 1.25 & 0.32 & -2.60 & \\
\hline $2 \mathrm{SE}$ & & & 0.13 & & & & 0.11 & & & & 0.19 & 0.11 & 0.13 & \\
\hline$\varepsilon_{\mathrm{Nd}(\mathrm{i})}$ & & & 1.06 & & & & 1.01 & & & & 1.76 & 0.84 & -1.98 & \\
\hline${ }^{206} \mathrm{~Pb} /{ }^{204} \mathrm{~Pb}$ & & & 18.9776 & & & & 18.8140 & & & & 18.8441 & 18.8588 & 18.7637 & \\
\hline & & & 0.0107 & & & & 0.0106 & & & & 0.0106 & 0.0107 & 0.0106 & \\
\hline${ }^{207} \mathrm{~Pb} /{ }^{204} \mathrm{~Pb}$ & & & 15.6330 & & & & 15.6278 & & & & 15.6305 & 15.6255 & 15.5753 & \\
\hline & & & 0.0233 & & & & 0.0231 & & & & 0.0232 & 0.0231 & 0.0231 & \\
\hline${ }^{208} \mathrm{~Pb} /{ }^{204} \mathrm{~Pb}$ & & & 38.8149 & & & & 38.7343 & & & & 38.7646 & 38.7616 & 38.6555 & \\
\hline & & & 0.0362 & & & & 0.0363 & & & & 0.0361 & 0.0362 & 0.0361 & \\
\hline${ }^{207} \mathrm{~Pb} /{ }^{206} \mathrm{~Pb}$ & & & 0.8238 & & & & 0.8307 & & & & 0.8295 & 0.8286 & 0.8301 & \\
\hline & & & 0.0008 & & & & 0.0008 & & & & 0.0008 & 0.0008 & 0.0008 & \\
\hline${ }^{208} \mathrm{~Pb} /{ }^{206} \mathrm{~Pb}$ & & & 2.0453 & & & & 2.0588 & & & & 2.0571 & 2.0554 & 2.0601 & \\
\hline & & & 0.0008 & & & & 0.0008 & & & & 0.0008 & 0.0008 & 0.0008 & \\
\hline${ }^{87} \mathrm{Sr} /{ }^{86} \mathrm{Sr}$ & & & 0.7047 & & & & 0.7047 & & & & 0.7031 & 0.7048 & 0.7062 & \\
\hline
\end{tabular}


Table 4.2. Zircon U-Pb geochronology results.

\begin{tabular}{|c|c|c|c|c|c|c|c|c|c|c|c|c|}
\hline $\begin{array}{l}\text { Ssample } \\
\text { name }\end{array}$ & $\begin{array}{c}\mathrm{U} \\
\mathrm{ppm}\end{array}$ & $\begin{array}{l}\text { Th } \\
\mathrm{U}\end{array}$ & ${ }^{238} \mathrm{U} /{ }^{206} \mathrm{~Pb}$ & $\begin{array}{l}1 \text { sigma } \\
\% \text { error }\end{array}$ & ${ }^{207} \mathrm{~Pb} /{ }^{206} \mathrm{~Pb}$ & $\begin{array}{l}1 \text { sigma } \\
\% \text { error }\end{array}$ & $\begin{array}{c}{ }^{206} \mathrm{~Pb} /{ }^{238} \mathrm{U} \\
\text { age }\end{array}$ & $\begin{array}{l}1 \text { sigma } \\
\text { abs err }\end{array}$ & $\begin{array}{c}{ }^{207} \mathrm{~Pb} /{ }^{206} \mathrm{~Pb} \\
\text { age }\end{array}$ & $\begin{array}{l}1 \text { sigma } \\
\text { abs err }\end{array}$ & Best age & $\begin{array}{c}1 \text { sigma } \\
\text { abs err Ma }\end{array}$ \\
\hline \multicolumn{13}{|c|}{ Hatillo Stock } \\
\hline CH8_53 & 639 & 0.52 & 116.7887 & 1.16 & 0.0476 & 1.79 & 55.0 & 0.6 & 78.0 & 41.9 & 55.0 & 0.6 \\
\hline CH8_52 & 284 & 0.30 & 117.3998 & 1.50 & 0.0522 & 2.53 & 54.7 & 0.8 & 293.4 & 56.8 & 54.7 & 0.8 \\
\hline CH8_51 & 593 & 0.43 & 116.4599 & 1.21 & 0.0482 & 1.87 & 55.1 & 0.7 & 110.1 & 43.6 & 55.1 & 0.7 \\
\hline CH8_50 & 618 & 0.34 & 122.8578 & 1.91 & 0.0515 & 2.44 & 52.3 & 1.0 & 262.0 & 55.1 & 52.3 & 1.0 \\
\hline CH8_49 & 375 & 0.32 & 117.6800 & 1.27 & 0.0482 & 2.31 & 54.5 & 0.7 & 107.1 & 53.8 & 54.5 & 0.7 \\
\hline CH8_48 & 330 & 0.54 & 117.0847 & 1.38 & 0.0504 & 2.34 & 54.8 & 0.8 & 212.1 & 53.3 & 54.8 & 0.8 \\
\hline CH8_47 & 282 & 0.46 & 115.1027 & 1.56 & 0.0445 & 2.99 & 55.8 & 0.9 & 0.0 & 0.0 & 55.8 & 0.9 \\
\hline CH8_46 & 533 & 0.27 & 122.6024 & 1.57 & 0.0519 & 1.72 & 52.4 & 0.8 & 279.6 & 38.9 & 52.4 & 0.8 \\
\hline CH8_45 & 279 & 0.35 & 117.2890 & 1.55 & 0.0471 & 3.21 & 54.7 & 0.8 & 52.5 & 74.9 & 54.7 & 0.8 \\
\hline CH8_44 & 629 & 0.36 & 116.0551 & 1.21 & 0.0482 & 1.65 & 55.3 & 0.7 & 110.7 & 38.4 & 55.3 & 0.7 \\
\hline CH8_43 & 255 & 0.33 & 111.7879 & 2.21 & 0.0513 & 4.47 & 57.4 & 1.3 & 255.5 & 99.6 & 57.4 & 1.3 \\
\hline CH8_42 & 768 & 0.44 & 118.6470 & 1.26 & 0.0479 & 1.60 & 54.1 & 0.7 & 93.5 & 37.4 & 54.1 & 0.7 \\
\hline CH8_41 & 440 & 0.36 & 114.0809 & 1.51 & 0.0474 & 2.30 & 56.3 & 0.8 & 69.2 & 53.8 & 56.3 & 0.8 \\
\hline CH8_40 & 383 & 0.51 & 114.1143 & 3.03 & 0.0538 & 4.77 & 56.2 & 1.7 & 363.4 & 104.1 & 56.2 & 1.7 \\
\hline CH8_39 & 481 & 0.52 & 118.7859 & 1.63 & 0.0473 & 2.14 & 54.0 & 0.9 & 66.6 & 50.2 & 54.0 & 0.9 \\
\hline CH8_38 & 600 & 0.28 & 117.6285 & 1.75 & 0.0456 & 2.66 & 54.6 & 1.0 & 0.0 & 41.6 & 54.6 & 1.0 \\
\hline CH8_37 & 595 & 0.44 & 120.7981 & 1.51 & 0.0463 & 1.60 & 53.1 & 0.8 & 15.1 & 37.9 & 53.1 & 0.8 \\
\hline CH8_36 & 282 & 0.34 & 119.5697 & 1.67 & 0.0482 & 2.65 & 53.7 & 0.9 & 108.6 & 61.4 & 53.7 & 0.9 \\
\hline CH8_35 & 279 & 0.33 & 115.7864 & 2.45 & 0.0630 & 3.24 & 55.4 & 1.4 & 708.2 & 67.4 & 55.4 & 1.4 \\
\hline CH8_34 & 383 & 0.64 & 109.8967 & 1.75 & 0.0575 & 2.41 & 58.4 & 1.0 & 509.0 & 52.2 & 58.4 & 1.0 \\
\hline CH8_33 & 277 & 0.61 & 111.1176 & 1.61 & 0.0471 & 2.77 & 57.8 & 0.9 & 53.3 & 64.7 & 57.8 & 0.9 \\
\hline CH8_32 & 565 & 0.15 & 88.9423 & 1.98 & 0.0499 & 1.33 & 72.1 & 1.4 & 190.1 & 30.6 & 72.1 & 1.4 \\
\hline CH8_31 & 317 & 0.31 & 118.8815 & 1.81 & 0.0499 & 3.73 & 54.0 & 1.0 & 188.3 & 84.6 & 54.0 & 1.0 \\
\hline CH8_30 & 434 & 0.49 & 117.2787 & 1.50 & 0.0456 & 2.00 & 54.7 & 0.8 & 0.0 & 24.4 & 54.7 & 0.8 \\
\hline CH8_29 & 218 & 0.26 & 113.2228 & 1.79 & 0.0526 & 2.86 & 56.7 & 1.0 & 312.9 & 63.9 & 56.7 & 1.0 \\
\hline CH8_28 & 348 & 0.32 & 117.0160 & 1.57 & 0.0480 & 2.23 & 54.9 & 0.9 & 97.6 & 51.9 & 54.9 & 0.9 \\
\hline CH8_27 & 553 & 0.35 & 120.4603 & 1.58 & 0.0478 & 1.80 & 53.3 & 0.8 & 91.2 & 42.2 & 53.3 & 0.8 \\
\hline
\end{tabular}




\begin{tabular}{|c|c|c|c|c|c|c|c|c|c|c|c|c|}
\hline CH8_26 & 197 & 0.21 & 117.0872 & 2.02 & 0.0452 & 3.13 & 54.8 & 1.1 & 0.0 & 28.1 & 54.8 & 1.1 \\
\hline CH8_25 & 419 & 0.94 & 43.6835 & 3.34 & 0.0591 & 1.75 & 145.9 & 4.8 & 569.5 & 37.6 & 145.9 & 4.8 \\
\hline CH8_24 & 404 & 0.43 & 119.1525 & 1.61 & 0.0490 & 2.39 & 53.9 & 0.9 & 146.7 & 55.0 & 53.9 & 0.9 \\
\hline CH8_23 & 260 & 0.47 & 123.7672 & 1.74 & 0.0461 & 2.83 & 51.9 & 0.9 & 3.4 & 66.4 & 51.9 & 0.9 \\
\hline CH8_22 & 578 & 0.30 & 108.1112 & 1.42 & 0.0490 & 1.80 & 59.4 & 0.8 & 146.4 & 41.7 & 59.4 & 0.8 \\
\hline CH8_21 & 342 & 0.55 & 113.5549 & 1.43 & 0.0576 & 2.37 & 56.5 & 0.8 & 515.3 & 51.2 & 56.5 & 0.8 \\
\hline CH8_20 & 813 & 0.26 & 82.5385 & 1.53 & 0.0502 & 1.49 & 77.6 & 1.2 & 205.9 & 34.2 & 77.6 & 1.2 \\
\hline CH8_19 & 178 & 0.33 & 117.0288 & 1.95 & 0.0493 & 3.16 & 54.8 & 1.1 & 161.0 & 72.4 & 54.8 & 1.1 \\
\hline CH8_18 & 241 & 0.33 & 117.2350 & 1.77 & 0.0444 & 2.93 & 54.8 & 1.0 & 0.0 & 0.0 & 54.8 & 1.0 \\
\hline CH8_17 & 505 & 0.33 & 120.0569 & 1.48 & 0.0470 & 2.14 & 53.5 & 0.8 & 48.9 & 50.4 & 53.5 & 0.8 \\
\hline CH8_16 & 226 & 0.42 & 129.2107 & 1.93 & 0.1453 & 4.01 & 49.7 & 1.0 & 2291.8 & 67.3 & 2291.8 & 67.3 \\
\hline CH8_15 & 570 & 0.37 & 114.4461 & 1.56 & 0.0607 & 1.92 & 56.1 & 0.9 & 627.0 & 40.8 & 56.1 & 0.9 \\
\hline CH8_14 & 511 & 0.38 & 122.3922 & 1.67 & 0.0461 & 1.97 & 52.5 & 0.9 & 0.0 & 48.8 & 52.5 & 0.9 \\
\hline CH8_13 & 282 & 0.36 & 116.6422 & 1.84 & 0.0509 & 2.53 & 55.0 & 1.0 & 234.8 & 57.4 & 55.0 & 1.0 \\
\hline CH8_12 & 688 & 0.47 & 117.4675 & 1.52 & 0.0482 & 1.86 & 54.6 & 0.8 & 108.7 & 43.4 & 54.6 & 0.8 \\
\hline CH8_11 & 295 & 0.19 & 117.2547 & 1.56 & 0.0471 & 2.89 & 54.7 & 0.9 & 52.4 & 67.6 & 54.7 & 0.9 \\
\hline CH8_10 & 380 & 0.44 & 117.0869 & 1.56 & 0.0475 & 2.40 & 54.8 & 0.8 & 75.8 & 56.0 & 54.8 & 0.8 \\
\hline CH8_9 & 554 & 0.34 & 119.7902 & 1.48 & 0.0480 & 1.98 & 53.6 & 0.8 & 101.0 & 46.2 & 53.6 & 0.8 \\
\hline CH8_8 & 366 & 0.34 & 118.0387 & 1.50 & 0.0474 & 2.48 & 54.4 & 0.8 & 71.5 & 58.0 & 54.4 & 0.8 \\
\hline CH8_7 & 624 & 0.46 & 117.9444 & 1.38 & 0.0499 & 2.02 & 54.4 & 0.7 & 192.4 & 46.4 & 54.4 & 0.7 \\
\hline CH8_6 & 651 & 0.80 & 121.8317 & 1.43 & 0.0462 & 1.97 & 52.7 & 0.8 & 1.1 & 53.4 & 52.7 & 0.8 \\
\hline CH8_5 & 479 & 0.31 & 117.0096 & 1.44 & 0.0452 & 2.21 & 54.9 & 0.8 & 0.0 & 5.4 & 54.9 & 0.8 \\
\hline CH8_4 & 384 & 0.35 & 116.5082 & 1.56 & 0.0483 & 2.27 & 55.1 & 0.9 & 112.7 & 52.6 & 55.1 & 0.9 \\
\hline CH8_3 & 486 & 0.45 & 115.8109 & 1.55 & 0.0480 & 2.20 & 55.4 & 0.9 & 99.3 & 51.2 & 55.4 & 0.9 \\
\hline CH8_2 & 249 & 0.31 & 119.1978 & 1.76 & 0.0459 & 2.90 & 53.9 & 0.9 & 0.0 & 63.2 & 53.9 & 0.9 \\
\hline CH8_1 & 329 & 0.41 & 121.0468 & 1.70 & 0.0451 & 2.69 & 53.0 & 0.9 & 0.0 & 15.4 & 53.0 & 0.9 \\
\hline CH19_35 & 404 & 0.49 & 123.5497 & 1.87 & 0.0471 & 1.95 & 52.0 & 1.0 & 54.8 & 45.9 & 52.0 & 1.0 \\
\hline CH19_34 & 336 & 0.37 & 111.0124 & 2.11 & 0.0687 & 2.39 & 57.8 & 1.2 & 890.6 & 48.6 & 57.8 & 1.2 \\
\hline CH19_33 & 641 & 0.53 & 118.7256 & 1.61 & 0.0479 & 1.63 & 54.1 & 0.9 & 94.3 & 38.1 & 54.1 & 0.9 \\
\hline CH19_32 & 903 & 0.32 & 118.1972 & 2.80 & 0.0473 & 2.65 & 54.3 & 1.5 & 62.4 & 62.0 & 54.3 & 1.5 \\
\hline CH19_31 & 643 & 0.58 & 124.4643 & 1.65 & 0.0488 & 1.77 & 51.6 & 0.8 & 137.9 & 41.1 & 51.6 & 0.8 \\
\hline
\end{tabular}




\begin{tabular}{|c|c|c|c|c|c|c|c|c|c|c|c|c|}
\hline CH19_30 & 208 & 0.27 & 90.9240 & 3.76 & 0.1521 & 4.83 & 70.5 & 2.6 & 2369.4 & 80.1 & 2369.4 & 80.1 \\
\hline CH19_29 & 434 & 0.49 & 120.2912 & 2.40 & 0.0511 & 2.70 & 53.4 & 1.3 & 244.1 & 61.0 & 53.4 & 1.3 \\
\hline CH19_28 & 488 & 0.37 & 125.2725 & 1.98 & 0.0446 & 2.01 & 51.3 & 1.0 & 0.0 & 0.0 & 51.3 & 1.0 \\
\hline CH19_27 & 650 & 0.46 & 114.5198 & 2.14 & 0.0472 & 1.59 & 56.0 & 1.2 & 61.8 & 37.4 & 56.0 & 1.2 \\
\hline CH19_26 & 817 & 0.53 & 112.7937 & 2.12 & 0.0472 & 1.49 & 56.9 & 1.2 & 61.3 & 35.2 & 56.9 & 1.2 \\
\hline CH19_25 & 314 & 0.41 & 109.0934 & 2.53 & 0.0452 & 4.18 & 58.8 & 1.5 & 0.0 & 53.7 & 58.8 & 1.5 \\
\hline CH19_23 & 641 & 0.43 & 114.9741 & 2.14 & 0.0480 & 1.86 & 55.8 & 1.2 & 98.4 & 43.4 & 55.8 & 1.2 \\
\hline CH19_22 & 607 & 0.31 & 128.1354 & 2.79 & 0.0449 & 2.34 & 50.1 & 1.4 & 0.0 & 0.0 & 50.1 & 1.4 \\
\hline CH19_21 & 560 & 0.44 & 106.8251 & 1.99 & 0.1000 & 2.58 & 60.1 & 1.2 & 1624.5 & 47.1 & 60.1 & 1.2 \\
\hline CH19_20 & 966 & 0.46 & 115.8011 & 1.59 & 0.0466 & 1.36 & 55.4 & 0.9 & 27.8 & 32.3 & 55.4 & 0.9 \\
\hline CH19_19 & 408 & 0.39 & 102.0586 & 1.78 & 0.0999 & 2.95 & 62.9 & 1.1 & 1621.4 & 54.0 & 62.9 & 1.1 \\
\hline CH19_18 & 638 & 0.38 & 117.0428 & 1.61 & 0.0451 & 1.66 & 54.8 & 0.9 & 0.0 & 0.0 & 54.8 & 0.9 \\
\hline CH19_17 & 596 & 0.42 & 115.4847 & 1.60 & 0.0471 & 1.67 & 55.6 & 0.9 & 54.8 & 39.3 & 55.6 & 0.9 \\
\hline CH19_16 & 548 & 0.40 & 111.5450 & 1.61 & 0.0461 & 1.75 & 57.5 & 0.9 & 0.0 & 45.2 & 57.5 & 0.9 \\
\hline CH19_15 & 531 & 0.47 & 115.6318 & 1.63 & 0.0486 & 1.91 & 55.5 & 0.9 & 127.0 & 44.3 & 55.5 & 0.9 \\
\hline CH19_14 & 1334 & 1.43 & 117.4698 & 1.53 & 0.0473 & 1.16 & 54.6 & 0.8 & 65.4 & 27.3 & 54.6 & 0.8 \\
\hline CH19_13 & 555 & 0.42 & 118.1211 & 2.51 & 0.0433 & 4.63 & 54.3 & 1.4 & 0.0 & 0.0 & 54.3 & 1.4 \\
\hline CH19_12 & 762 & 0.56 & 111.7852 & 1.27 & 0.0499 & 1.62 & 57.4 & 0.7 & 192.2 & 37.2 & 57.4 & 0.7 \\
\hline CH19_10 & 803 & 0.29 & 128.3049 & 1.98 & 0.0555 & 1.22 & 50.0 & 1.0 & 431.8 & 26.9 & 50.0 & 1.0 \\
\hline CH19_9 & 515 & 0.54 & 114.3863 & 1.48 & 0.0475 & 1.90 & 56.1 & 0.8 & 75.6 & 44.6 & 56.1 & 0.8 \\
\hline CH19_8 & 641 & 0.37 & 117.1635 & 1.46 & 0.0468 & 1.67 & 54.8 & 0.8 & 36.8 & 39.5 & 54.8 & 0.8 \\
\hline CH19_7 & 398 & 0.50 & 118.1455 & 1.67 & 0.0483 & 2.28 & 54.3 & 0.9 & 114.8 & 53.0 & 54.3 & 0.9 \\
\hline CH19_6 & 589 & 0.42 & 112.5541 & 2.08 & 0.0472 & 1.80 & 57.0 & 1.2 & 60.7 & 42.3 & 57.0 & 1.2 \\
\hline CH19_4 & 539 & 0.34 & 116.0968 & 2.60 & 0.0467 & 3.44 & 55.3 & 1.4 & 32.8 & 80.3 & 55.3 & 1.4 \\
\hline CH19_3 & 688 & 0.41 & 114.4027 & 2.04 & 0.0474 & 1.66 & 56.1 & 1.1 & 68.9 & 39.0 & 56.1 & 1.1 \\
\hline CH19_2 & 1002 & 0.50 & 117.5739 & 2.02 & 0.0480 & 1.54 & 54.6 & 1.1 & 97.9 & 36.1 & 54.6 & 1.1 \\
\hline CH19_1 & 543 & 0.37 & 116.6847 & 2.04 & 0.0469 & 1.99 & 55.0 & 1.1 & 46.1 & 46.8 & 55.0 & 1.1 \\
\hline CH5_26 & 429 & 0.28 & 118.5998 & 2.34 & 0.0479 & 2.11 & 54.1 & 1.3 & 94.8 & 49.2 & 54.1 & 1.3 \\
\hline CH5_25 & 710 & 0.39 & 119.1388 & 2.40 & 0.0458 & 1.60 & 53.9 & 1.3 & 0.0 & 24.3 & 53.9 & 1.3 \\
\hline CH5_24 & 543 & 0.44 & 123.6454 & 2.62 & 0.0468 & 1.92 & 51.9 & 1.4 & 37.6 & 45.2 & 51.9 & 1.4 \\
\hline CH5_23 & 673 & 0.35 & 119.3373 & 2.42 & 0.0490 & 1.71 & 53.8 & 1.3 & 149.9 & 39.5 & 53.8 & 1.3 \\
\hline
\end{tabular}




\begin{tabular}{|c|c|c|c|c|c|c|c|c|c|c|c|}
\hline CH5_22 & 420 & 0.33 & 118.2779 & 2.32 & 0.0467 & 2.11 & 54.3 & 1.3 & 32.0 & 49.9 & 54.3 \\
\hline CH5_21 & 546 & 0.41 & 117.7984 & 2.26 & 0.0450 & 1.78 & 54.5 & 1.2 & 0.0 & 0.0 & 54.5 \\
\hline CH5_20 & 970 & 0.42 & 120.1819 & 1.48 & 0.0454 & 1.32 & 53.4 & 0.8 & 0.0 & 0.5 & 53.4 \\
\hline CH5_19 & 830 & 0.46 & 120.7208 & 1.49 & 0.0472 & 1.45 & 53.2 & 0.8 & 58.6 & 34.2 & 53.2 \\
\hline CH5_18 & 559 & 0.40 & 119.4792 & 1.52 & 0.0477 & 2.52 & 53.7 & 0.8 & 83.4 & 58.8 & 53.7 \\
\hline CH5_17 & 367 & 0.35 & 121.3569 & 1.31 & 0.0478 & 2.36 & 52.9 & 0.7 & 90.8 & 54.9 & 52.9 \\
\hline CH5_16 & 426 & 0.28 & 119.3378 & 1.78 & 0.0448 & 2.18 & 53.8 & 1.0 & 0.0 & 0.0 & 53.8 \\
\hline CH5_15 & 757 & 0.19 & 120.5872 & 2.23 & 0.0497 & 1.64 & 53.2 & 1.2 & 181.5 & 37.7 & 53.2 \\
\hline CH5_14 & 453 & 0.31 & 119.8515 & 1.53 & 0.0474 & 2.02 & 53.6 & 0.8 & 68.4 & 47.5 & 53.6 \\
\hline CH5_13 & 332 & 0.33 & 121.4643 & 1.53 & 0.0452 & 2.32 & 52.9 & 0.8 & 0.0 & 7.8 & 52.9 \\
\hline CH5_12 & 453 & 0.29 & 123.1242 & 1.63 & 0.0451 & 2.03 & 52.1 & 0.8 & 0.0 & 0.0 & 52.1 \\
\hline CH5_11 & 635 & 0.35 & 118.1343 & 1.29 & 0.0478 & 1.85 & 54.3 & 0.7 & 89.6 & 43.2 & 54.3 \\
\hline CH5_10 & 689 & 0.43 & 117.7050 & 1.59 & 0.0465 & 1.69 & 54.5 & 0.9 & 24.8 & 40.2 & 54.5 \\
\hline CH5_9 & 638 & 0.37 & 118.4383 & 1.26 & 0.0479 & 1.75 & 54.2 & 0.7 & 93.7 & 40.9 & 54.2 \\
\hline CH5_8 & 487 & 0.33 & 119.6996 & 1.88 & 0.0603 & 2.33 & 53.6 & 1.0 & 615.2 & 49.5 & 53.6 \\
\hline CH5_7 & 362 & 0.36 & 121.9317 & 1.45 & 0.0460 & 2.34 & 52.7 & 0.8 & 0.0 & 53.9 & 52.7 \\
\hline CH5_6 & 397 & 0.41 & 122.7623 & 2.14 & 0.0445 & 2.95 & 52.3 & 1.1 & 0.0 & 0.0 & 52.3 \\
\hline CH5_5 & 611 & 0.39 & 116.9712 & 1.17 & 0.0464 & 1.85 & 54.9 & 0.6 & 20.3 & 43.7 & 54.9 \\
\hline CH5_4 & 522 & 0.42 & 117.6472 & 1.15 & 0.0478 & 1.89 & 54.6 & 0.6 & 89.7 & 44.1 & 54.6 \\
\hline CH5_3 & 519 & 0.29 & 117.8210 & 1.22 & 0.0485 & 1.85 & 54.5 & 0.7 & 124.0 & 43.0 & 54.5 \\
\hline CH5_2 & 633 & 0.29 & 119.2765 & 1.20 & 0.0477 & 1.78 & 53.8 & 0.6 & 86.0 & 41.7 & 53.8 \\
\hline CH5_1 & 419 & 0.35 & 118.2616 & 1.37 & 0.0457 & 2.43 & 54.3 & 0.7 & 0.0 & 37.9 & 54.3 \\
\hline CH20_59 & 470 & 0.46 & 121.7720 & 1.07 & 0.0472 & 2.53 & 52.7 & 0.6 & 59.6 & 59.2 & 52.7 \\
\hline CH20_58 & 440 & 0.31 & 117.9028 & 1.11 & 0.0481 & 2.55 & 54.4 & 0.6 & 105.1 & 59.3 & 54.4 \\
\hline CH20_57 & 683 & 0.32 & 117.2195 & 0.95 & 0.0458 & 2.21 & 54.8 & 0.5 & 1.7 & 39.2 & 54.8 \\
\hline CH20_56 & 707 & 0.12 & 116.2659 & 0.96 & 0.0484 & 2.12 & 55.2 & 0.5 & 119.3 & 49.3 & 55.2 \\
\hline CH20_55 & 503 & 0.39 & 115.7745 & 1.12 & 0.0443 & 2.36 & 55.4 & 0.6 & 0.0 & 0.0 & 55.4 \\
\hline CH20_54 & 454 & 0.32 & 119.5344 & 1.06 & 0.0484 & 2.59 & 53.7 & 0.6 & 118.0 & 59.9 & 53.7 \\
\hline CH20_53 & 442 & 0.37 & 117.4617 & 1.23 & 0.0471 & 2.67 & 54.6 & 0.7 & 52.0 & 62.3 & 54.6 \\
\hline CH20_52 & 630 & 0.30 & 120.2849 & 0.99 & 0.0448 & 2.40 & 53.4 & 0.5 & 0.0 & 0.0 & 53.4 \\
\hline CH20_51 & 358 & 0.41 & 115.9385 & 1.16 & 0.0752 & 3.11 & 55.4 & 0.6 & 1074.8 & 61.3 & 55.4 \\
\hline
\end{tabular}




\begin{tabular}{|c|c|c|c|c|c|c|c|c|c|c|c|c|}
\hline CH20_50 & 1686 & 0.02 & 112.6869 & 0.89 & 0.0468 & 1.86 & 57.0 & 0.5 & 39.3 & 43.3 & 57.0 & 0.5 \\
\hline CH20_49 & 568 & 0.29 & 120.5321 & 1.03 & 0.0462 & 2.26 & 53.3 & 0.5 & 12.3 & 49.1 & 53.3 & 0.5 \\
\hline CH20_48 & 840 & 0.27 & 112.9796 & 0.91 & 0.0460 & 2.10 & 56.8 & 0.5 & 6.5 & 42.1 & 56.8 & 0.5 \\
\hline CH20_47 & 969 & 0.66 & 119.2160 & 1.01 & 0.0485 & 2.42 & 53.8 & 0.5 & 123.9 & 56.1 & 53.8 & 0.5 \\
\hline CH20_46 & 895 & 0.52 & 114.5063 & 0.88 & 0.0474 & 1.27 & 56.1 & 0.5 & 70.6 & 30.0 & 56.1 & 0.5 \\
\hline CH20_45 & 356 & 0.38 & 113.0473 & 1.22 & 0.0472 & 2.19 & 56.8 & 0.7 & 57.6 & 51.4 & 56.8 & 0.7 \\
\hline CH20_44 & 634 & 0.40 & 117.0914 & 1.09 & 0.0477 & 1.58 & 54.8 & 0.6 & 85.3 & 37.1 & 54.8 & 0.6 \\
\hline CH20_43 & 524 & 0.39 & 116.1139 & 0.95 & 0.0485 & 1.76 & 55.3 & 0.5 & 124.1 & 40.9 & 55.3 & 0.5 \\
\hline CH20_42 & 605 & 0.35 & 112.3550 & 1.03 & 0.0492 & 1.56 & 57.1 & 0.6 & 158.8 & 36.0 & 57.1 & 0.6 \\
\hline CH20_41 & 631 & 0.38 & 109.2411 & 1.51 & 0.0518 & 2.15 & 58.7 & 0.9 & 276.2 & 48.4 & 58.7 & 0.9 \\
\hline CH20_40 & 656 & 0.35 & 121.1067 & 1.05 & 0.0470 & 1.52 & 53.0 & 0.6 & 47.8 & 35.8 & 53.0 & 0.6 \\
\hline CH20_39 & 663 & 0.52 & 116.6390 & 0.86 & 0.0463 & 1.71 & 55.0 & 0.5 & 17.6 & 38.8 & 55.0 & 0.5 \\
\hline CH20_38 & 1055 & 0.78 & 116.5167 & 0.77 & 0.0456 & 1.34 & 55.1 & 0.4 & 0.0 & 10.2 & 55.1 & 0.4 \\
\hline CH20_37 & 746 & 0.37 & 117.7309 & 0.97 & 0.0478 & 1.58 & 54.5 & 0.5 & 89.0 & 36.9 & 54.5 & 0.5 \\
\hline CH20_36 & 472 & 0.40 & 114.4093 & 1.09 & 0.0491 & 1.75 & 56.1 & 0.6 & 151.7 & 40.4 & 56.1 & 0.6 \\
\hline CH20_35 & 907 & 0.56 & 116.5040 & 0.85 & 0.0465 & 1.28 & 55.1 & 0.5 & 23.3 & 29.5 & 55.1 & 0.5 \\
\hline CH20_34 & 543 & 0.40 & 113.5858 & 1.05 & 0.0514 & 1.73 & 56.5 & 0.6 & 258.9 & 39.3 & 56.5 & 0.6 \\
\hline CH20_33 & 1014 & 0.53 & 115.6806 & 0.84 & 0.0465 & 1.29 & 55.5 & 0.5 & 25.9 & 29.9 & 55.5 & 0.5 \\
\hline CH20_32 & 517 & 0.34 & 115.6263 & 1.38 & 0.0472 & 2.59 & 55.5 & 0.8 & 58.7 & 60.7 & 55.5 & 0.8 \\
\hline CH20_31 & 384 & 0.44 & 119.9059 & 1.32 & 0.0508 & 2.13 & 53.5 & 0.7 & 233.9 & 48.4 & 53.5 & 0.7 \\
\hline CH20_30 & 906 & 0.58 & 117.8432 & 1.02 & 0.0468 & 1.46 & 54.5 & 0.6 & 37.3 & 35.1 & 54.5 & 0.6 \\
\hline CH20_29 & 761 & 0.46 & 117.4885 & 1.03 & 0.0480 & 1.68 & 54.6 & 0.6 & 97.7 & 39.3 & 54.6 & 0.6 \\
\hline CH20_28 & 504 & 0.40 & 114.1921 & 1.17 & 0.0470 & 2.04 & 56.2 & 0.7 & 50.7 & 48.0 & 56.2 & 0.7 \\
\hline CH20_27 & 593 & 0.41 & 122.4846 & 1.27 & 0.0477 & 1.67 & 52.4 & 0.7 & 84.4 & 39.1 & 52.4 & 0.7 \\
\hline CH20_26 & 376 & 0.30 & 117.3802 & 1.19 & 0.0467 & 2.26 & 54.7 & 0.6 & 31.6 & 53.9 & 54.7 & 0.6 \\
\hline CH20_25 & 419 & 0.50 & 111.7609 & 1.24 & 0.0507 & 2.29 & 57.4 & 0.7 & 226.7 & 52.0 & 57.4 & 0.7 \\
\hline CH20_24 & 516 & 0.39 & 123.1354 & 1.54 & 0.0481 & 2.96 & 52.1 & 0.8 & 103.6 & 68.5 & 52.1 & 0.8 \\
\hline CH20_23 & 758 & 0.39 & 112.5658 & 1.07 & 0.0471 & 1.43 & 57.0 & 0.6 & 56.7 & 33.8 & 57.0 & 0.6 \\
\hline CH20_22 & 725 & 0.47 & 119.9760 & 1.10 & 0.0473 & 1.45 & 53.5 & 0.6 & 64.3 & 34.3 & 53.5 & 0.6 \\
\hline CH20_21 & 870 & 0.47 & 118.4597 & 1.27 & 0.0495 & 1.79 & 54.2 & 0.7 & 171.9 & 41.3 & 54.2 & 0.7 \\
\hline CH20_20 & 704 & 0.32 & 119.3396 & 2.01 & 0.0523 & 3.21 & 53.8 & 1.1 & 298.7 & 71.7 & 53.8 & 1.1 \\
\hline CH20_19 & 970 & 0.20 & 106.3910 & 1.64 & 0.0495 & 2.68 & 60.3 & 1.0 & 170.4 & 61.4 & 60.3 & 1.0 \\
\hline
\end{tabular}




\begin{tabular}{|c|c|c|c|c|c|c|c|c|c|c|c|}
\hline CH20_18 & 851 & 0.41 & 116.5628 & 1.11 & 0.0460 & 1.45 & 55.1 & 0.6 & 0.0 & 28.9 & 55.1 \\
\hline CH20_17 & 703 & 0.40 & 118.2311 & 1.06 & 0.0462 & 1.65 & 54.3 & 0.6 & 0.0 & 45.5 & 54.3 \\
\hline CH20_16 & 547 & 0.38 & 118.5687 & 1.07 & 0.0475 & 1.74 & 54.1 & 0.6 & 74.8 & 41.0 & 54.1 \\
\hline CH20_15 & 514 & 0.31 & 114.8243 & 1.13 & 0.0467 & 1.98 & 55.9 & 0.6 & 28.0 & 52.4 & 55.9 \\
\hline CH20_14 & 432 & 0.37 & 118.0405 & 1.23 & 0.0444 & 2.09 & 54.4 & 0.7 & 0.0 & 0.0 & 54.4 \\
\hline CH20_13 & 856 & 0.38 & 110.3357 & 1.01 & 0.0539 & 1.62 & 58.2 & 0.6 & 367.9 & 36.1 & 58.2 \\
\hline CH20_12 & 568 & 0.39 & 118.9510 & 1.42 & 0.0476 & 2.44 & 54.0 & 0.8 & 80.8 & 56.9 & 54.0 \\
\hline CH20_11 & 585 & 0.45 & 110.5514 & 1.27 & 0.0540 & 2.23 & 58.0 & 0.7 & 370.0 & 49.5 & 58.0 \\
\hline CH20_10 & 522 & 0.35 & 119.7113 & 1.22 & 0.0575 & 2.59 & 53.6 & 0.6 & 509.8 & 56.0 & 53.6 \\
\hline CH20_9 & 399 & 0.47 & 120.4389 & 1.45 & 0.0448 & 2.27 & 53.3 & 0.8 & 0.0 & 0.0 & 53.3 \\
\hline CH20_8 & 254 & 0.43 & 118.4004 & 1.45 & 0.0663 & 2.99 & 54.2 & 0.8 & 814.6 & 61.3 & 54.2 \\
\hline CH20_7 & 353 & 0.34 & 114.9395 & 1.28 & 0.0469 & 2.48 & 55.8 & 0.7 & 42.2 & 58.2 & 55.8 \\
\hline CH20_6 & 361 & 0.37 & 114.4565 & 1.24 & 0.0470 & 2.19 & 56.1 & 0.7 & 50.8 & 51.5 & 56.1 \\
\hline CH20_5 & 886 & 0.43 & 122.7491 & 1.05 & 0.0491 & 1.53 & 52.3 & 0.5 & 152.2 & 35.5 & 52.3 \\
\hline CH20_4 & 605 & 0.54 & 119.2683 & 1.17 & 0.0512 & 1.65 & 53.8 & 0.6 & 252.0 & 37.6 & 53.8 \\
\hline CH20_3 & 519 & 0.50 & 118.2828 & 1.18 & 0.0512 & 1.73 & 54.3 & 0.6 & 249.5 & 39.4 & 54.3 \\
\hline CH20_2 & 732 & 0.65 & 118.8927 & 1.14 & 0.0458 & 1.58 & 54.0 & 0.6 & 0.0 & 27.5 & 54.0 \\
\hline CH20_1 & 565 & 0.45 & 114.7077 & 1.20 & 0.0464 & 1.89 & 56.0 & 0.7 & 17.7 & 43.4 & 56.0 \\
\hline CH21B_58 & 569 & 0.35 & 110.5036 & 1.59 & 0.0512 & 2.90 & 58.1 & 0.9 & 250.7 & 65.4 & 58.1 \\
\hline CH21B_57 & 611 & 0.30 & 118.5465 & 1.10 & 0.0466 & 2.00 & 54.2 & 0.6 & 30.4 & 46.6 & 54.2 \\
\hline CH21B_56 & 450 & 0.37 & 110.0967 & 1.16 & 0.0668 & 2.00 & 58.3 & 0.7 & 832.1 & 41.2 & 58.3 \\
\hline CH21B_55 & 738 & 0.57 & 107.9856 & 0.93 & 0.0595 & 1.56 & 59.4 & 0.6 & 583.7 & 33.4 & 59.4 \\
\hline CH21B_54 & 890 & 0.77 & 117.2460 & 0.99 & 0.0470 & 1.52 & 54.7 & 0.5 & 47.9 & 35.7 & 54.7 \\
\hline CH21B_53 & 456 & 0.58 & 112.7132 & 1.04 & 0.0494 & 1.97 & 56.9 & 0.6 & 166.7 & 45.4 & 56.9 \\
\hline CH21B_52 & 867 & 0.67 & 112.3715 & 1.00 & 0.0495 & 1.55 & 57.1 & 0.6 & 169.7 & 35.8 & 57.1 \\
\hline CH21B_51 & 709 & 0.40 & 101.7259 & 1.02 & 0.0464 & 1.65 & 63.1 & 0.6 & 20.5 & 37.7 & 63.1 \\
\hline CH21B_50 & 1050 & 1.23 & 114.8644 & 1.12 & 0.0560 & 1.88 & 55.9 & 0.6 & 452.3 & 41.3 & 55.9 \\
\hline CH21B_49 & 572 & 0.39 & 118.5879 & 1.71 & 0.0612 & 3.49 & 54.1 & 0.9 & 647.3 & 73.3 & 54.1 \\
\hline CH21B_48 & 701 & 0.55 & 116.9080 & 1.08 & 0.0476 & 1.60 & 54.9 & 0.6 & 80.8 & 37.5 & 54.9 \\
\hline CH21B_47 & 518 & 0.41 & 116.2740 & 1.18 & 0.0455 & 1.85 & 55.2 & 0.6 & 0.0 & 17.2 & 55.2 \\
\hline CH21B_46 & 630 & 0.32 & 117.7114 & 1.01 & 0.0469 & 1.79 & 54.5 & 0.5 & 46.6 & 42.0 & 54.5 \\
\hline
\end{tabular}




\begin{tabular}{|c|c|c|c|c|c|c|c|c|c|c|c|c|}
\hline CH21B_45 & 598 & 0.45 & 116.8899 & 1.09 & 0.0467 & 1.81 & 54.9 & 0.6 & 34.1 & 42.2 & 54.9 & 0.6 \\
\hline CH21B_44 & 762 & 0.38 & 127.5047 & 1.73 & 0.0484 & 2.63 & 50.4 & 0.9 & 119.9 & 60.8 & 50.4 & 0.9 \\
\hline CH21B_43 & 476 & 0.46 & 116.2572 & 1.24 & 0.0483 & 2.07 & 55.2 & 0.7 & 112.4 & 48.1 & 55.2 & 0.7 \\
\hline CH21B_42 & 1285 & 0.40 & 128.0855 & 1.02 & 0.0481 & 1.32 & 50.1 & 0.5 & 103.9 & 30.9 & 50.1 & 0.5 \\
\hline CH21B_41 & 508 & 0.38 & 115.0152 & 1.17 & 0.0489 & 1.79 & 55.8 & 0.6 & 141.9 & 41.5 & 55.8 & 0.6 \\
\hline CH21B_40 & 483 & 0.77 & 121.3087 & 1.29 & 0.0455 & 2.32 & 52.9 & 0.7 & 0.0 & 29.0 & 52.9 & 0.7 \\
\hline CH21B_39 & 468 & 0.39 & 112.2577 & 1.18 & 0.0473 & 2.01 & 57.2 & 0.7 & 64.7 & 47.2 & 57.2 & 0.7 \\
\hline CH21B_38 & 519 & 0.53 & 121.6586 & 1.19 & 0.0486 & 2.07 & 52.8 & 0.6 & 128.0 & 48.0 & 52.8 & 0.6 \\
\hline CH21B_37 & 878 & 0.43 & 118.2187 & 1.08 & 0.0465 & 1.64 & 54.3 & 0.6 & 26.2 & 38.1 & 54.3 & 0.6 \\
\hline CH21B_36 & 645 & 0.34 & 116.3561 & 1.09 & 0.0479 & 1.66 & 55.2 & 0.6 & 94.4 & 38.7 & 55.2 & 0.6 \\
\hline CH21B_35 & 348 & 0.44 & 120.1570 & 1.61 & 0.0531 & 2.87 & 53.4 & 0.9 & 334.4 & 63.8 & 53.4 & 0.9 \\
\hline CH21B_34 & 634 & 0.54 & 115.0497 & 1.00 & 0.0505 & 1.95 & 55.8 & 0.6 & 218.6 & 44.5 & 55.8 & 0.6 \\
\hline CH21B_33 & 284 & 0.38 & 127.6559 & 2.29 & 0.0967 & 4.69 & 50.3 & 1.1 & 1560.8 & 85.5 & 50.3 & 1.1 \\
\hline CH21B_32 & 586 & 0.93 & 114.9558 & 1.31 & 0.0500 & 1.68 & 55.8 & 0.7 & 194.6 & 38.7 & 55.8 & 0.7 \\
\hline CH21B_31 & 609 & 0.43 & 112.7245 & 1.22 & 0.0469 & 1.76 & 56.9 & 0.7 & 42.1 & 41.4 & 56.9 & 0.7 \\
\hline CH21B_30 & 658 & 0.49 & 116.1230 & 1.19 & 0.0481 & 1.55 & 55.3 & 0.7 & 105.3 & 36.2 & 55.3 & 0.7 \\
\hline CH21B_29 & 2098 & 0.40 & 113.9008 & 1.29 & 0.0475 & 1.39 & 56.3 & 0.7 & 72.1 & 32.7 & 56.3 & 0.7 \\
\hline CH21B_28 & 279 & 0.28 & 121.8820 & 1.52 & 0.0507 & 3.41 & 52.7 & 0.8 & 228.7 & 76.8 & 52.7 & 0.8 \\
\hline CH21B_27 & 521 & 0.34 & 117.0228 & 1.25 & 0.0675 & 2.06 & 54.9 & 0.7 & 852.3 & 42.3 & 54.9 & 0.7 \\
\hline CH21B_26 & 542 & 0.45 & 111.9209 & 1.23 & 0.0478 & 1.93 & 57.3 & 0.7 & 87.8 & 45.0 & 57.3 & 0.7 \\
\hline CH21B_25 & 839 & 0.51 & 116.4525 & 1.15 & 0.0471 & 1.61 & 55.1 & 0.6 & 52.7 & 37.9 & 55.1 & 0.6 \\
\hline CH21B_24 & 318 & 0.38 & 124.3521 & 2.00 & 0.0508 & 3.52 & 51.6 & 1.0 & 232.1 & 79.2 & 51.6 & 1.0 \\
\hline CH21B_23 & 1498 & 0.38 & 115.0808 & 1.45 & 0.0480 & 1.56 & 55.8 & 0.8 & 99.1 & 36.5 & 55.8 & 0.8 \\
\hline CH21B_22 & 463 & 0.51 & 119.4276 & 1.76 & 0.0452 & 2.01 & 53.8 & 0.9 & 0.0 & 2.7 & 53.8 & 0.9 \\
\hline CH21B_21 & 526 & 0.42 & 112.9143 & 1.42 & 0.0475 & 1.87 & 56.8 & 0.8 & 75.2 & 43.8 & 56.8 & 0.8 \\
\hline CH21B_20 & 1864 & 0.24 & 82.4515 & 1.34 & 0.0485 & 1.13 & 77.7 & 1.0 & 123.5 & 26.4 & 77.7 & 1.0 \\
\hline CH21B_19 & 527 & 0.36 & 120.6280 & 1.43 & 0.0473 & 1.87 & 53.2 & 0.8 & 62.6 & 43.9 & 53.2 & 0.8 \\
\hline CH21B_18 & 1330 & 0.40 & 101.6564 & 1.42 & 0.0470 & 1.33 & 63.1 & 0.9 & 51.4 & 31.5 & 63.1 & 0.9 \\
\hline CH21B_17 & 521 & 0.39 & 118.9768 & 1.52 & 0.0470 & 2.00 & 54.0 & 0.8 & 48.4 & 47.2 & 54.0 & 0.8 \\
\hline CH21B_16 & 514 & 0.47 & 116.5607 & 1.40 & 0.0491 & 1.93 & 55.1 & 0.8 & 154.0 & 44.6 & 55.1 & 0.8 \\
\hline CH21B_15 & 662 & 0.47 & 122.5278 & 1.35 & 0.0460 & 1.80 & 52.4 & 0.7 & 0.0 & 42.0 & 52.4 & 0.7 \\
\hline CH21B_14 & 577 & 0.43 & 109.1142 & 1.39 & 0.0483 & 1.78 & 58.8 & 0.8 & 114.9 & 41.4 & 58.8 & 0.8 \\
\hline
\end{tabular}




\begin{tabular}{|c|c|c|c|c|c|c|c|c|c|c|c|c|}
\hline CH21B_13 & 513 & 0.48 & 117.5736 & 1.46 & 0.0484 & 1.91 & 54.6 & 0.8 & 117.5 & 44.5 & 54.6 & 0.8 \\
\hline CH21B_12 & 821 & 0.38 & 123.6892 & 1.34 & 0.0479 & 1.59 & 51.9 & 0.7 & 94.5 & 37.2 & 51.9 & 0.7 \\
\hline CH21B_11 & 868 & 0.61 & 114.2735 & 1.49 & 0.0517 & 1.58 & 56.2 & 0.8 & 274.1 & 35.8 & 56.2 & 0.8 \\
\hline CH21B_10 & 544 & 0.34 & 111.9777 & 1.11 & 0.0492 & 1.96 & 57.3 & 0.6 & 155.8 & 45.2 & 57.3 & 0.6 \\
\hline CH21B_9 & 302 & 0.43 & 118.0706 & 1.31 & 0.0456 & 2.30 & 54.4 & 0.7 & 0.0 & 31.5 & 54.4 & 0.7 \\
\hline CH21B_8 & 842 & 0.47 & 123.3954 & 1.08 & 0.0474 & 1.45 & 52.0 & 0.6 & 68.3 & 34.1 & 52.0 & 0.6 \\
\hline CH21B_7 & 667 & 0.56 & 122.8859 & 1.11 & 0.0513 & 1.81 & 52.2 & 0.6 & 254.7 & 41.1 & 52.2 & 0.6 \\
\hline CH21B_6 & 589 & 0.42 & 115.5410 & 1.18 & 0.0480 & 1.87 & 55.6 & 0.7 & 99.6 & 43.6 & 55.6 & 0.7 \\
\hline CH21B_5 & 693 & 0.50 & 120.5734 & 1.04 & 0.0498 & 1.82 & 53.2 & 0.5 & 187.9 & 41.9 & 53.2 & 0.5 \\
\hline CH21B_4 & 932 & 0.30 & 120.0275 & 0.92 & 0.0481 & 1.56 & 53.5 & 0.5 & 104.2 & 36.4 & 53.5 & 0.5 \\
\hline CH21B_3 & 407 & 0.54 & 121.3948 & 1.22 & 0.0564 & 2.28 & 52.9 & 0.6 & 469.5 & 49.7 & 52.9 & 0.6 \\
\hline CH21B_2 & 347 & 0.38 & 122.9232 & 1.28 & 0.0457 & 2.49 & 52.2 & 0.7 & 0.0 & 39.8 & 52.2 & 0.7 \\
\hline CH21B_1 & 1224 & 0.37 & 115.9095 & 0.97 & 0.0443 & 1.55 & 55.4 & 0.5 & 0.0 & 0.0 & 55.4 & 0.5 \\
\hline \multicolumn{13}{|c|}{ Bosque batholith } \\
\hline CB1_33 & 3991 & 0.19 & 118.0425 & 1.67 & 0.0517 & 1.10 & 54.4 & 0.9 & 271.4 & 25.1 & 54.4 & 0.9 \\
\hline CB1_32 & 13720 & 0.07 & 109.1547 & 1.97 & 0.0466 & 0.97 & 58.8 & 1.2 & 30.9 & 23.0 & 58.8 & 1.2 \\
\hline CB1_31 & 587 & 0.38 & 112.9761 & 1.98 & 0.0458 & 2.11 & 56.8 & 1.1 & 0.0 & 35.8 & 56.8 & 1.1 \\
\hline CB1_30 & 3206 & 0.26 & 116.4683 & 1.66 & 0.0468 & 1.21 & 55.1 & 0.9 & 40.0 & 28.8 & 55.1 & 0.9 \\
\hline CB1_29 & 2185 & 0.28 & 112.7510 & 2.04 & 0.0469 & 1.57 & 56.9 & 1.2 & 43.2 & 37.1 & 56.9 & 1.2 \\
\hline CB1_28 & 824 & 0.26 & 16.2261 & 2.01 & 0.0668 & 1.13 & 385.5 & 7.5 & 832.7 & 23.4 & 385.5 & 7.5 \\
\hline CB1_27 & 2123 & 0.25 & 113.0986 & 1.76 & 0.0464 & 1.66 & 56.7 & 1.0 & 16.7 & 39.3 & 56.7 & 1.0 \\
\hline CB1_26 & 1502 & 0.34 & 26.5206 & 1.54 & 0.0702 & 0.88 & 238.6 & 3.6 & 935.4 & 18.0 & 238.6 & 3.6 \\
\hline CB1_25 & 940 & 0.09 & 119.0885 & 1.59 & 0.0477 & 1.59 & 53.9 & 0.9 & 86.4 & 37.4 & 53.9 & 0.9 \\
\hline CB1_24 & 2402 & 0.28 & 120.0046 & 1.79 & 0.0466 & 1.41 & 53.5 & 1.0 & 28.7 & 33.5 & 53.5 & 1.0 \\
\hline CB1_23 & 6537 & 0.11 & 117.6860 & 1.43 & 0.0490 & 0.87 & 54.5 & 0.8 & 148.7 & 20.2 & 54.5 & 0.8 \\
\hline CB1_22 & 252 & 0.62 & 118.4373 & 3.49 & 0.0507 & 5.98 & 54.2 & 1.9 & 227.5 & 132.5 & 54.2 & 1.9 \\
\hline CB1_21 & 2646 & 0.24 & 112.0430 & 1.47 & 0.0471 & 1.09 & 57.3 & 0.8 & 54.7 & 25.9 & 57.3 & 0.8 \\
\hline CB1_20 & 1062 & 0.45 & 26.8682 & 1.61 & 0.0525 & 1.24 & 235.6 & 3.7 & 308.3 & 28.0 & 235.6 & 3.7 \\
\hline CB1_19 & 865 & 0.12 & 119.9749 & 1.60 & 0.0485 & 1.64 & 53.5 & 0.9 & 121.5 & 38.3 & 53.5 & 0.9 \\
\hline CB1_18 & 621 & 1.32 & 9.8090 & 1.40 & 0.0606 & 0.79 & 625.8 & 8.3 & 624.7 & 16.9 & 625.8 & 8.3 \\
\hline CB1_17 & 2663 & 0.46 & 81.5246 & 1.97 & 0.0531 & 1.65 & 78.6 & 1.5 & 331.1 & 36.9 & 78.6 & 1.5 \\
\hline CB1_16 & 4508 & 0.15 & 108.2290 & 1.46 & 0.0465 & 0.87 & 59.3 & 0.9 & 22.8 & 20.6 & 59.3 & 0.9 \\
\hline
\end{tabular}




\begin{tabular}{|c|c|c|c|c|c|c|c|c|c|c|c|c|}
\hline CB1_15 & 1055 & 0.42 & 111.8473 & 1.50 & 0.0486 & 1.44 & 57.4 & 0.9 & 128.3 & 33.6 & 57.4 & 0.9 \\
\hline CB1_14 & 1344 & 0.20 & 76.0193 & 1.96 & 0.0561 & 0.82 & 84.2 & 1.6 & 458.3 & 18.1 & 84.2 & 1.6 \\
\hline CB1_13 & 2244 & 0.24 & 109.8940 & 1.48 & 0.0469 & 1.00 & 58.4 & 0.9 & 43.5 & 23.7 & 58.4 & 0.9 \\
\hline CB1_12 & 3135 & 0.24 & 115.4386 & 1.53 & 0.0472 & 1.19 & 55.6 & 0.8 & 60.9 & 28.0 & 55.6 & 0.8 \\
\hline CB1_11 & 1935 & 0.24 & 112.7442 & 1.78 & 0.0474 & 1.53 & 56.9 & 1.0 & 69.7 & 35.9 & 56.9 & 1.0 \\
\hline CB1_10 & 668 & 0.45 & 115.7464 & 1.25 & 0.0461 & 1.63 & 55.5 & 0.7 & 0.0 & 39.7 & 55.5 & 0.7 \\
\hline CB1_9 & 2508 & 0.21 & 114.3365 & 1.18 & 0.0471 & 1.04 & 56.1 & 0.7 & 54.1 & 24.5 & 56.1 & 0.7 \\
\hline CB1_8 & 4726 & 0.21 & 113.0889 & 1.11 & 0.0471 & 0.72 & 56.8 & 0.6 & 54.7 & 17.0 & 56.8 & 0.6 \\
\hline CB1_7 & 743 & 0.32 & 112.3122 & 1.42 & 0.0475 & 1.61 & 57.1 & 0.8 & 73.3 & 37.7 & 57.1 & 0.8 \\
\hline CB1_6 & 1757 & 0.18 & 113.4217 & 1.84 & 0.0463 & 1.03 & 56.6 & 1.0 & 12.0 & 23.7 & 56.6 & 1.0 \\
\hline CB1_5 & 2030 & 0.15 & 111.0487 & 1.86 & 0.0475 & 1.26 & 57.8 & 1.1 & 76.9 & 29.6 & 57.8 & 1.1 \\
\hline CB1_4 & 1465 & 0.24 & 112.3340 & 1.84 & 0.0461 & 1.27 & 57.1 & 1.0 & 5.8 & 28.0 & 57.1 & 1.0 \\
\hline CB1_3 & 1270 & 0.28 & 118.9109 & 2.03 & 0.0482 & 1.52 & 54.0 & 1.1 & 108.7 & 35.5 & 54.0 & 1.1 \\
\hline CB1_2 & 2435 & 0.18 & 110.1076 & 1.81 & 0.0473 & 0.98 & 58.3 & 1.0 & 63.4 & 23.3 & 58.3 & 1.0 \\
\hline CB1_1 & 1554 & 1.13 & 113.8881 & 2.08 & 0.0465 & 1.14 & 56.4 & 1.2 & 21.7 & 27.0 & 56.4 & 1.2 \\
\hline
\end{tabular}


Table 4.3. Zircon Hf isotope results.

\begin{tabular}{|c|c|c|c|c|c|c|c|c|c|c|c|}
\hline Sample & ${ }^{176} \mathrm{Hf} /{ }^{177} \mathrm{Hf}$ & $2 \mathrm{SE}$ & ${ }^{176} \mathrm{Lu} /{ }^{177} \mathrm{Hf}$ & $2 \mathrm{SE}$ & ${ }^{176} \mathrm{Yb} /{ }^{177} \mathrm{Hf}$ & $2 \mathrm{SE}$ & AGE & ${ }^{176} \mathrm{Hf}^{177} \mathrm{Hf}_{(\mathrm{i})}$ & $\varepsilon \mathrm{Hf}_{(0)}$ & $2 \mathrm{SE}$ & $\varepsilon \mathrm{Hf}_{(\mathrm{i})}$ \\
\hline \multicolumn{12}{|c|}{ Bosque Batholith } \\
\hline $\mathrm{CB} 1$ & 0.282789 & 0.000027 & 0.00221 & 0.00005 & 0.05470 & 0.00150 & 56.4 & 0.282789 & 0.1 & 1.0 & 1.3 \\
\hline CB1 & 0.282700 & 0.000026 & 0.00115 & 0.00002 & 0.03233 & 0.00054 & 58.3 & 0.282700 & -3.0 & 0.9 & -1.8 \\
\hline CB1 & 0.282638 & 0.000021 & 0.00012 & 0.00000 & 0.00329 & 0.00002 & 57.1 & 0.282638 & -5.2 & 0.7 & -3.9 \\
\hline $\mathrm{CB} 1$ & 0.282661 & 0.000030 & 0.00031 & 0.00001 & 0.00909 & 0.00019 & 57.8 & 0.282661 & -4.4 & 1.1 & -3.1 \\
\hline CB1 & 0.282624 & 0.000029 & 0.00085 & 0.00002 & 0.02235 & 0.00090 & 56.6 & 0.282624 & -5.7 & 1.0 & -4.5 \\
\hline CB1 & 0.282654 & 0.000024 & 0.00016 & 0.00002 & 0.00460 & 0.00042 & 56.8 & 0.282654 & -4.6 & 0.8 & -3.4 \\
\hline CB1 & 0.282694 & 0.000028 & 0.00035 & 0.00001 & 0.00967 & 0.00014 & 58.8 & 0.282694 & -3.2 & 1.0 & -1.9 \\
\hline $\mathrm{CB} 1$ & 0.282694 & 0.000029 & 0.00059 & 0.00001 & 0.01698 & 0.00025 & 56.9 & 0.282694 & -3.2 & 1.0 & -2.0 \\
\hline \multicolumn{12}{|c|}{ Hatillo Stock } \\
\hline $\mathrm{CH} 5$ & 0.282801 & 0.000026 & 0.00102 & 0.00001 & 0.02445 & 0.00018 & 54.3 & 0.282801 & 0.6 & 0.9 & 1.7 \\
\hline CH5 & 0.282796 & 0.000020 & 0.00134 & 0.00002 & 0.03101 & 0.00066 & 54.9 & 0.282796 & 0.4 & 0.7 & 1.6 \\
\hline CH5 & 0.282796 & 0.000026 & 0.00118 & 0.00004 & 0.02813 & 0.00094 & 52.3 & 0.282796 & 0.4 & 0.9 & 1.5 \\
\hline CH5 & 0.282635 & 0.000037 & 0.00105 & 0.00004 & 0.02610 & 0.00120 & 53.6 & 0.282635 & -5.3 & 1.3 & -4.2 \\
\hline CH5 & 0.282813 & 0.000024 & 0.00066 & 0.00001 & 0.01505 & 0.00032 & 54.2 & 0.282813 & 1.0 & 0.8 & 2.2 \\
\hline CH5 & 0.282430 & 0.000120 & 0.00070 & 0.00004 & 0.01656 & 0.00092 & 52.1 & 0.282430 & -12.6 & 4.2 & -11.4 \\
\hline CH5 & 0.282803 & 0.000028 & 0.00106 & 0.00002 & 0.02445 & 0.00051 & 53.9 & 0.282803 & 0.6 & 1.0 & 1.8 \\
\hline CH5 & 0.282791 & 0.000030 & 0.00087 & 0.00007 & 0.02040 & 0.00160 & 54.5 & 0.282791 & 0.2 & 1.1 & 1.4 \\
\hline $\mathrm{CH} 8$ & 0.282744 & 0.000032 & 0.00261 & 0.00029 & 0.06810 & 0.00790 & 52.7 & 0.282744 & -1.4 & 1.1 & -0.4 \\
\hline $\mathrm{CH} 8$ & 0.282815 & 0.000028 & 0.00111 & 0.00005 & 0.02691 & 0.00095 & 53.0 & 0.282815 & 1.1 & 1.0 & 2.2 \\
\hline $\mathrm{CH} 8$ & 0.282732 & 0.000030 & 0.00099 & 0.00010 & 0.02540 & 0.00270 & 53.9 & 0.282732 & -1.9 & 1.1 & -0.7 \\
\hline CH8 & 0.282751 & 0.000034 & 0.00083 & 0.00005 & 0.02070 & 0.00120 & 54.4 & 0.282751 & -1.2 & 1.2 & 0.0 \\
\hline CH8 & 0.282752 & 0.000027 & 0.00079 & 0.00002 & 0.01874 & 0.00047 & 53.6 & 0.282752 & -1.2 & 1.0 & 0.0 \\
\hline $\mathrm{CH} 8$ & 0.282808 & 0.000033 & 0.00078 & 0.00003 & 0.01921 & 0.00080 & 52.3 & 0.282808 & 0.8 & 1.2 & 1.9 \\
\hline $\mathrm{CH} 8$ & 0.282806 & 0.000026 & 0.00061 & 0.00006 & 0.01430 & 0.00140 & 51.9 & 0.282806 & 0.7 & 0.9 & 1.9 \\
\hline $\mathrm{CH} 8$ & 0.282819 & 0.000027 & 0.00071 & 0.00002 & 0.01681 & 0.00062 & 54.7 & 0.282819 & 1.2 & 1.0 & 2.4 \\
\hline $\mathrm{CH} 10$ & 0.282420 & 0.000160 & 0.00061 & 0.00004 & 0.01470 & 0.00110 & 52.4 & 0.282420 & -12.9 & 5.7 & -11.8 \\
\hline
\end{tabular}




\begin{tabular}{|c|c|c|c|c|c|c|c|c|c|c|c|}
\hline $\mathrm{CH} 10$ & 0.282835 & 0.000026 & 0.00086 & 0.00003 & 0.02029 & 0.00074 & 54.1 & 0.282835 & 1.8 & 0.9 & 2.9 \\
\hline $\mathrm{CH} 10$ & 0.282820 & 0.000027 & 0.00195 & 0.00023 & 0.04920 & 0.00590 & 55.1 & 0.282820 & 1.2 & 1.0 & 2.4 \\
\hline $\mathrm{CH} 10$ & 0.282793 & 0.000021 & 0.00101 & 0.00010 & 0.02500 & 0.00270 & 55.1 & 0.282793 & 0.3 & 0.7 & 1.5 \\
\hline $\mathrm{CH} 10$ & 0.282820 & 0.000023 & 0.00085 & 0.00003 & 0.02085 & 0.00078 & 53.6 & 0.282820 & 1.2 & 0.8 & 2.4 \\
\hline $\mathrm{CH} 10$ & .282823 & 0.000024 & 0.00095 & .00002 & 0.02275 & 0.00059 & 54.1 & 0.282823 & 1.3 & .8 & 2.5 \\
\hline CH10 & 0.282740 & 0.000048 & 0.00094 & 0.00013 & 0.02280 & 0.00340 & 51.8 & 0.282740 & -1.6 & 1.7 & -0.5 \\
\hline $\mathrm{CH} 10$ & 0.282815 & 0.000029 & 0.00068 & 0.00002 & 0.01571 & 0.00027 & 55.9 & 0.282815 & 1.1 & 1.0 & 2.3 \\
\hline $\mathrm{CH} 10$ & 0.282774 & 0.000028 & 0.00102 & 0.00012 & 0.03200 & 0.00450 & 52.2 & 0.282774 & -0.4 & 1.0 & 0.7 \\
\hline CH19 & 0.282863 & 0.000028 & 0.00090 & 0.00003 & 0.02167 & 0.00058 & 55.0 & 0.282863 & 2.8 & 1.0 & 3.9 \\
\hline CH19 & 0.282784 & 0.000048 & 0.00089 & 0.00005 & 0.02180 & 0.00100 & 54.6 & 0.282784 & 0.0 & 1.7 & 1.1 \\
\hline CH19 & 0.282856 & 0.000027 & 0.00077 & 0.00003 & 0.01959 & 0.00099 & 55.3 & 0.282856 & 2.5 & 1.0 & 3.7 \\
\hline CH19 & 0.282877 & 0.000042 & 0.00188 & 0.00008 & 0.04930 & 0.00230 & 54.6 & 0.282877 & 3.3 & 1.5 & 4.4 \\
\hline CH19 & 0.282877 & 0.000031 & 0.00069 & 0.00004 & 0.01685 & 0.00087 & 55.6 & 0.282877 & 3.3 & 1.1 & 4.5 \\
\hline CH19 & 0.282790 & 0.000078 & 0.00089 & 0.00006 & 0.02130 & 0.00120 & 51.6 & 0.282790 & 0.2 & 2.8 & 1.3 \\
\hline CH19 & 0.282819 & 0.000038 & 0.00091 & 0.00004 & 0.02198 & 0.00087 & 54.3 & 0.282819 & 1.2 & 1.3 & 2.4 \\
\hline CH19 & 0.282908 & 0.000042 & 0.00083 & 0.00005 & 0.02050 & 0.00120 & 57.8 & 0.282908 & 4.3 & 1.5 & 5.6 \\
\hline $\mathrm{CH} 21 \mathrm{~B}$ & 0.282835 & 0.000029 & 0.00098 & 0.00004 & 0.02380 & 0.00077 & 52.2 & 0.282835 & 1.8 & 1.0 & 2.9 \\
\hline $\mathrm{CH} 21 \mathrm{~B}$ & 0.282855 & 0.000032 & 0.00088 & 0.00003 & 0.02158 & 0.00069 & 51.9 & 0.282855 & 2.5 & 1.1 & 3.6 \\
\hline $\mathrm{CH} 21 \mathrm{~B}$ & 0.282812 & 0.000034 & 0.00167 & 0.00015 & 0.04270 & 0.00380 & 58.8 & 0.282812 & 1.0 & 1.2 & 2.2 \\
\hline $\mathrm{CH} 21 \mathrm{~B}$ & 0.282817 & 0.000032 & 0.00085 & 0.00001 & 0.02116 & 0.00023 & 52.4 & 0.282817 & 1.1 & 1.1 & 2.3 \\
\hline $\mathrm{CH} 21 \mathrm{~B}$ & 0.282852 & 0.000026 & 0.00077 & 0.00003 & 0.02004 & 0.00083 & 54.9 & 0.282852 & 2.4 & 0.9 & 3.6 \\
\hline $\mathrm{CH} 21 \mathrm{~B}$ & 0.282814 & 0.000032 & 0.00221 & 0.00040 & 0.06200 & 0.01200 & 52.9 & 0.282814 & 1.0 & 1.1 & 2.1 \\
\hline $\mathrm{CH} 21 \mathrm{~B}$ & 0.282852 & 0.000026 & 0.00112 & 0.00004 & 0.02942 & 0.00092 & 52.8 & 0.282852 & 2.4 & 0.9 & 3.5 \\
\hline $\mathrm{CH} 21 \mathrm{~B}$ & 0.282861 & 0.000032 & 0.00122 & 0.00014 & 0.03090 & 0.00350 & 56.9 & 0.282861 & 2.7 & 1.1 & 3.9 \\
\hline MLH1_10 & 0.282852 & 0.000023 & 0.0006 & 0.000037 & 0.01568 & 0.00096 & 50.7 & 0.282851 & 2.4 & 0.8 & 3.5 \\
\hline MLH1_9 & 0.282839 & 0.000022 & 0.00062 & 0.000016 & 0.01567 & 0.00042 & 53.0 & 0.282838 & 1.9 & 0.8 & 3.1 \\
\hline MLH1_8 & 0.282796 & 0.000025 & 0.00065 & 0.000025 & 0.01752 & 0.00079 & 53.0 & 0.282795 & 0.4 & 0.9 & 1.5 \\
\hline MLH1_7 & 0.282807 & 0.000030 & 0.00087 & 0.00003 & 0.02414 & 0.00077 & 53.2 & 0.282806 & 0.8 & 1.1 & 1.9 \\
\hline MLH1_6 & 0.282807 & 0.000026 & 0.00065 & 0.000027 & 0.01734 & 0.00074 & 53.5 & 0.282806 & 0.8 & 0.9 & 1.9 \\
\hline MLH1_5 & 0.282850 & 0.000022 & 0.00069 & 0.000027 & 0.01762 & 0.00068 & 53.8 & 0.282849 & 2.3 & 0.8 & 3.5 \\
\hline
\end{tabular}




\begin{tabular}{|c|c|c|c|c|c|c|c|c|c|c|c|}
\hline MLH1_4 & 0.282821 & 0.000027 & 0.00063 & 0.000032 & 0.01611 & 0.00082 & 54.2 & 0.282820 & 1.3 & 1.0 & 2.5 \\
\hline MLH1_3 & 0.282815 & 0.000048 & 0.00187 & 0.00042 & 0.05100 & 0.012 & 57.5 & 0.282813 & 1.1 & 1.7 & 2.3 \\
\hline MLH1_2 & 0.282791 & 0.000026 & .00305 & 0.00037 & 0.09600 & 0.012 & 63.5 & 282787 & 0.2 & 0.9 & 1.5 \\
\hline MLH1_1 & 0.282295 & 0.000077 & 0.00095 & 0.000027 & 0.02700 & 0.0012 & 1000.0 & 0.282277 & -17.3 & 2.7 & 4.4 \\
\hline \multicolumn{12}{|c|}{ D928 - Bogotá Fm. (Tuff) } \\
\hline D928_19 & 0.282950 & 0.000024 & 0.00058 & 0.000047 & 0.01680 & 0.0015 & 50.0 & 0.282949 & 5.8 & 0.9 & 6.9 \\
\hline D928_18 & 0.282916 & 0.000026 & 0.00087 & 0.000052 & 0.02450 & 0.0015 & 50.0 & 0.282915 & 4.6 & 0.9 & 5.7 \\
\hline D928_17 & 0.282574 & 0.000022 & 0.00163 & 0.000018 & 0.05118 & 0.00045 & 50.0 & 0.282572 & -7.5 & 0.8 & -6.4 \\
\hline D928_16 & 0.282347 & 0.000025 & .0014 & 0.000034 & 0.04520 & 0.0012 & 50.0 & .282346 & -15.5 & 0.9 & -14.4 \\
\hline D928_15 & 0.282593 & 0.000036 & 0.00106 & 0.000089 & 0.02700 & 0.0017 & 54.0 & 0.282592 & -6.8 & 1.3 & -5.6 \\
\hline D928_14 & 0.282641 & 0.000027 & 0.00123 & 0.000044 & 0.03440 & 0.0012 & 54.7 & 0.282640 & -5.1 & 1.0 & -3.9 \\
\hline D928_13 & 0.282877 & 0.000030 & 0.00059 & 0.000043 & 0.01680 & 0.0012 & 56.2 & 0.282876 & 3.3 & 1.1 & 4.5 \\
\hline D928_12 & 0.282944 & 0.000028 & 0.00067 & 0.00003 & 0.01809 & 0.00095 & 56.4 & 0.282943 & 5.6 & 1.0 & 6.9 \\
\hline D928_11 & 0.282910 & 0.000031 & 0.00066 & 0.000018 & 0.01741 & 0.00073 & 57.6 & 0.282909 & 4.4 & 1.1 & 5.7 \\
\hline D928_10 & 0.282895 & 0.000027 & 0.00099 & 0.000065 & 0.02770 & 0.002 & 57.9 & 0.282894 & 3.9 & 1.0 & 5.1 \\
\hline D928_9 & 0.282949 & 0.000032 & 0.00095 & 0.000045 & 0.02830 & 0.0013 & 58.4 & 0.282948 & 5.8 & 1.1 & 7.1 \\
\hline D928_8 & 0.282910 & 0.000027 & 0.00087 & 0.000049 & 0.02380 & 0.0012 & 58.4 & 0.282909 & 4.4 & 1.0 & 5.7 \\
\hline D928_7 & 0.282939 & 0.000024 & 0.00069 & 0.000044 & 0.02030 & 0.00 & 58.8 & 0.282938 & 5.4 & 0.9 & 6.7 \\
\hline D928_6 & 0.282931 & 0.000027 & 0.00121 & 0.000091 & 0.03340 & 0.0022 & 59.0 & 0.282930 & 5.2 & 1.0 & 6.4 \\
\hline D928_5 & 0.282651 & 0.000027 & 0.00106 & 0.000035 & 0.03010 & 0.001 & 60.0 & 0.282650 & -4.7 & 1.0 & -3.4 \\
\hline D928_4 & 0.282617 & 0.000038 & 0.00129 & 0.000073 & 0.03660 & 0.0021 & 60.8 & 0.282616 & -5.9 & 1.3 & -4.6 \\
\hline D928_3 & 0.282730 & 0.000024 & 0.00105 & 0.000066 & 0.03270 & 0.002 & 61.0 & 0.282729 & -1.9 & 0.9 & -0.6 \\
\hline D928_2 & 0.282506 & 0.000056 & 0.00097 & 0.000057 & 0.02820 & 0.0022 & 100.1 & 0.282504 & -9.9 & 2.0 & -7.7 \\
\hline D928_1 & 0.282684 & 0.000038 & 0.00148 & 0.00013 & 0.04210 & 0.0038 & 141.0 & 0.282680 & -3.6 & 1.3 & -0.6 \\
\hline \multicolumn{12}{|c|}{ D937 - Bogotá Fm. (Sandstone) } \\
\hline D937_1 & 0.282653 & 0.000027 & 0.00096 & 0.000038 & 0.02600 & 0.0011 & 55.0 & 0.282652 & -4.7 & 1.0 & -3.5 \\
\hline D937_2 & 0.282918 & 0.000025 & 0.00094 & 0.00002 & 0.02545 & 0.00069 & 55.0 & 0.282917 & 4.7 & 0.9 & 5.9 \\
\hline D937_3 & 0.282684 & 0.000022 & 0.00105 & 0.000025 & 0.02843 & 0.00096 & 56.0 & 0.282683 & -3.6 & 0.8 & -2.4 \\
\hline D937_4 & 0.282952 & 0.000034 & 0.00104 & 0.00008 & 0.03000 & 0.0026 & 56.0 & 0.282951 & 5.9 & 1.2 & 7.1 \\
\hline D937_5 & 0.282701 & 0.000024 & 0.00095 & 0.000011 & 0.02612 & 0.00027 & 57.4 & 0.282700 & -3.0 & 0.9 & -1.7 \\
\hline
\end{tabular}




\begin{tabular}{|c|c|c|c|c|c|c|c|c|c|c|c|}
\hline D937_6 & 0.282663 & 0.000027 & 0.00094 & 0.000036 & 0.02590 & 0.0011 & 57.7 & 0.282662 & -4.3 & 1.0 & -3.1 \\
\hline D937_7 & 0.282910 & 0.000030 & 0.00095 & 0.000034 & 0.02630 & 0.0011 & 58.5 & 0.282909 & 4.4 & 1.1 & 5.7 \\
\hline D937_8 & 0.282677 & 0.000059 & 0.00114 & 0.000048 & 0.02990 & 0.00044 & 58.9 & 0.282676 & -3.8 & 2.1 & -2.6 \\
\hline D937_9 & 0.282921 & 0.000019 & 0.00081 & 0.000033 & 0.02273 & 0.00093 & 59.2 & 0.282920 & 4.8 & 0.7 & 6.1 \\
\hline D937_10 & 0.282654 & 0.000034 & 0.00283 & 0.00018 & 0.07720 & 0.0053 & 60.0 & 0.282651 & -4.6 & 1.2 & -3.4 \\
\hline D937_11 & 0.282978 & 0.000043 & 0.00134 & 0.000092 & 0.03910 & 0.0029 & 60.1 & 0.282976 & 6.8 & 1.5 & 8.1 \\
\hline 12 & 0.282705 & 0025 & 00116 & 0017 & 28 & 0046 & 60.5 & 704 & -2.8 & 9 & -1.5 \\
\hline D937_13 & 0.282918 & 0.000027 & 0.0007 & 0.000056 & 0.01820 & 0.0015 & 60.7 & 0.282917 & 4.7 & 1.0 & 6.0 \\
\hline D937_14 & 0.282893 & 0.000024 & 0.00047 & 0.00002 & 0.01356 & 0.00062 & 61.8 & 0.282892 & 3.8 & 0.9 & 5.2 \\
\hline D937_15 & 0.282677 & 0.000032 & 0.0011 & 0.000021 & 0.02960 & 0.00049 & 62.8 & 0.282676 & -3.8 & 1.1 & -2.5 \\
\hline 937_16 & 634 & 31 & 162 & 14 & 0. & 47 & 62.9 & 632 & -5.3 & 1.1 & -4.0 \\
\hline D937_17 & 0.282660 & 0.000031 & 0.00152 & 0.000045 & 0.04150 & 0.0011 & 63.0 & .282658 & -4.4 & 1.1 & -3.1 \\
\hline D937_18 & 0.282677 & 0.000023 & 0.00127 & 0.000024 & 0.03405 & 0.00078 & 63.2 & 0.282675 & -3.8 & 0.8 & -2.5 \\
\hline D937_19 & 0.282681 & 0.000040 & 0.00115 & 0.000081 & 0.03340 & 0.0026 & 63.4 & 0.282680 & -3.7 & 1.4 & -2.3 \\
\hline 937_20 & 0.282675 & 0.0 & 0 & 0 & 1 & 0 & 63.5 & 0.282674 & -3.9 & 0.7 & -2.5 \\
\hline D937_21 & 0.282666 & 0.000029 & 0.00138 & 0.000037 & 0.03810 & 0.0011 & 64.3 & 2664 & -4.2 & 1.0 & -2.8 \\
\hline D937_22 & 0.282689 & 0.000024 & 0.0011 & 0.000055 & 0.03020 & 0.0014 & 64.5 & 0.282688 & -3.4 & 0.9 & -2.0 \\
\hline D937_23 & 0.282931 & 0.000031 & 0.00092 & 0.000052 & 0.02620 & 0.0012 & 65.0 & 0.282930 & 5.2 & 1.1 & 6.6 \\
\hline D937_24 & 0.282669 & 0.000028 & 0.0011 & 0.000036 & 0.02922 & 0.00081 & 65.4 & 0.282668 & -4.1 & 1.0 & -2.7 \\
\hline D937_25 & 0.282939 & 0.000021 & 0.00108 & 0.000032 & 0.03120 & 0.00071 & 66.6 & 0.282938 & 5.4 & 0.7 & 6.9 \\
\hline D937_26 & 0.282914 & 0.000025 & 0.00079 & 0.00004 & 0.02130 & 0.001 & 66.7 & 0.282913 & 4.6 & 0.9 & 6.0 \\
\hline D937_27 & 0.282646 & 0.000030 & 0.00126 & 0.000081 & 0.03570 & 0.0023 & 67.5 & 0.282644 & -4.9 & 1.1 & -3.5 \\
\hline 37_28 & 282964 & 0.000023 & 0.00094 & .00003 & 0.02464 & 0.00088 & 67.6 & .282963 & 6.3 & 0.8 & 7.8 \\
\hline D937_29 & 0.282780 & 0.000047 & 0.00221 & 0.00017 & 0.07010 & 0.0056 & 68.1 & 0.282777 & -0.2 & 1.7 & 1.2 \\
\hline D937_30 & 0.282555 & 0.000041 & 0.00167 & 0.00015 & 0.04550 & 0.0041 & 69.6 & 0.282553 & -8.1 & 1.5 & -6.7 \\
\hline D937_31 & 0.282633 & 0.000033 & 0.00141 & 0.000045 & 0.03900 & 0.0012 & 70.1 & 0.282631 & -5.4 & 1.2 & -3.9 \\
\hline D937_32 & 0.282938 & 0.000043 & 0.00121 & 0.000083 & 0.03340 & 0.0021 & 70.6 & 0.282936 & 5.4 & 1.5 & 6.9 \\
\hline D937_33 & 0.282900 & 0.000021 & 0.00054 & 0.000016 & 0.01447 & 0.00044 & 70.8 & 0.282899 & 4.1 & 0.7 & 5.6 \\
\hline D937_34 & 0.282901 & 0.000026 & 0.00097 & 0.000021 & 0.03029 & 0.00085 & 70.9 & 0.282900 & 4.1 & 0.9 & 5.6 \\
\hline D937_35 & 0.282911 & 0.000026 & 0.00092 & 0.000092 & 0.02570 & 0.0026 & 72.1 & 0.282910 & 4.5 & 0.9 & 6.0 \\
\hline
\end{tabular}




\begin{tabular}{|c|c|c|c|c|c|c|c|c|c|c|c|}
\hline 937_36 & 0.282895 & 0.000024 & 0.00065 & 0.000066 & 0.01880 & 0.0018 & 73.6 & 0.282894 & 3.9 & 0.9 & 5.5 \\
\hline D937_37 & 0.282649 & 0.000026 & 0.00101 & 0.00003 & 0.02607 & 0.00092 & 75.2 & 0.282648 & -4.8 & 0.9 & -3.2 \\
\hline 937 & 0.282859 & 0.000025 & 00057 & 0.000012 & 01706 & 0.00026 & 76.4 & 0.282858 & 2.6 & 0.9 & 4.3 \\
\hline D937_39 & 0.282679 & 0.000024 & .00105 & 0.000056 & 0.02930 & 0.0016 & 76.5 & 0.282678 & -3.7 & 0.9 & -2.1 \\
\hline D937_40 & 0.282670 & 0.000030 & 0.00118 & 0.000043 & 0.03301 & 0.00098 & 77.8 & 0.282668 & -4.1 & 1.1 & -2.4 \\
\hline 93 & 0.282562 & 0.000038 & 00114 & 0.000031 & 0.03262 & 0.00098 & 81.8 & 60 & -7.9 & .3 & -6.1 \\
\hline 937_42 & 0.282789 & .000026 & .00108 & 0.000036 & 0.03220 & 0.0014 & 83.9 & 0.282787 & 0.1 & 0.9 & 1.9 \\
\hline D937_43 & 0.282684 & 0.000027 & 0.00116 & 0.000049 & 0.03140 & 0.0013 & 89.0 & 2682 & -3.6 & .0 & -1.7 \\
\hline D937_44 & 0.282643 & 0.000028 & 0.00126 & 0.000031 & 0.03442 & 0.00081 & 89.0 & 0.282641 & -5.0 & 1.0 & -3.1 \\
\hline D937_45 & 15 & 24 & 61 & 9 & 6 & 7 & 89.6 & 4 & 4.6 & 0.9 & 6.6 \\
\hline 46 & 0.282687 & 0.000032 & .00133 & 0.000041 & 0.03730 & .0016 & 91.9 & 82685 & -3.5 & 1.1 & -1.5 \\
\hline D937_47 & 0.282792 & 0.000028 & 0.00139 & 0.000056 & 0.04130 & 0.0017 & 93.2 & 0.282790 & 0.2 & 1.0 & 2.2 \\
\hline D937_48 & 0.282794 & 0.000036 & 0.0014 & 0.00002 & 0.04106 & 0.00074 & 98.2 & 0.282791 & 0.3 & 1.3 & 2.4 \\
\hline D02 & 0.2 & 0.0 & 0 & 9 & 0 & 3 & 99.2 & 0.282678 & -3.7 & 1.0 & -1.6 \\
\hline & 0.282638 & 0.000025 & .00104 & 0.000033 & 0.02928 & 0.00097 & 107.3 & .282636 & -5.2 & 0.9 & -2.9 \\
\hline D937_51 & 0.282859 & 0.000030 & 0.00075 & 0.00012 & 0.02180 & 0.0034 & 109.3 & 0.282857 & 2.6 & 1.1 & 5.0 \\
\hline D937_52 & 0.282853 & 0.000027 & 0.001 & 0.000026 & 0.03041 & 0.00089 & 125.2 & 0.282851 & 2.4 & 1.0 & 5.1 \\
\hline D937_53 & 0.282879 & 0.000030 & 0.00058 & 0.000049 & 0.01600 & 0.0013 & 130.3 & 0.282878 & 3.3 & 1.1 & 6.2 \\
\hline D937_54 & 0.282873 & 025 & 0.00099 & 016 & 0.05192 & 0.00041 & 142.1 & 0.282870 & 3.1 & .9 & 6.2 \\
\hline D937_55 & 0.282788 & 0.000037 & 0.00119 & 0.000056 & 0.03090 & 0.0013 & 144.4 & 0.282785 & 0.1 & 1.3 & 3.2 \\
\hline D937_56 & 0.282647 & 0.000031 & 0.00088 & 0.00001 & 0.02482 & 0.00061 & 146.4 & 0.282645 & -4.9 & 1.1 & -1.7 \\
\hline - & .282897 & 000030 & 0.00086 & .000072 & 0.02300 & 0.0019 & 152.1 & .282895 & 4.0 & 1 & 7.3 \\
\hline D937_58 & 0.282714 & 0.000025 & 0.00091 & 0.000024 & 0.02507 & 0.00081 & 156.0 & 0.282711 & -2.5 & 0.9 & 0.9 \\
\hline D937_59 & 0.282837 & 0.000026 & 0.00104 & 0.000022 & 0.02665 & 0.00062 & 161.3 & 0.282834 & 1.8 & 0.9 & 5.3 \\
\hline D937_60 & 0.282830 & 0.000030 & 0.00095 & 0.000064 & 0.02540 & 0.0018 & 176.6 & 0.282827 & 1.6 & 1.1 & 5.4 \\
\hline D937_61 & 0.282773 & 0.000024 & 0.00123 & 0.000054 & 0.03580 & 0.0018 & 177.9 & 0.282769 & -0.4 & 0.9 & 3.4 \\
\hline D937_62 & 0.282946 & 0.000033 & 0.00068 & 0.000026 & 0.01898 & 0.00071 & 180.5 & 0.282944 & 5.7 & 1.2 & 9.6 \\
\hline D937_63 & 0.282765 & 0.000022 & 0.00065 & 0.00002 & 0.01871 & 0.00048 & 186.3 & 0.282763 & -0.7 & 0.8 & 3.4 \\
\hline D937_64 & 0.282376 & 0.000027 & 0.0003 & 0.000063 & 0.00980 & 0.0017 & 193.5 & 0.282375 & -14.5 & 1.0 & -10.2 \\
\hline D937_65 & 0.282702 & 0.000030 & 0.00111 & 0.000023 & 0.03098 & 0.00074 & 194.9 & 0.282698 & -2.9 & 1.1 & 1.3 \\
\hline
\end{tabular}




\begin{tabular}{|c|c|c|c|c|c|c|c|c|c|c|c|}
\hline D937_66 & 0.282905 & 0.000030 & 0.00098 & 0.000062 & 0.02790 & 0.0016 & 210.3 & 0.282901 & 4.2 & 1.1 & 8.8 \\
\hline D937_67 & 0.282559 & 0.000032 & 0.00178 & 0.000077 & 0.05970 & 0.003 & 215.0 & 0.282552 & -8.0 & 1.1 & -3.5 \\
\hline D937_68 & 0.282561 & 0.000028 & 0.00101 & 0.000065 & 0.02860 & 0.0019 & 242.7 & 0.282556 & -7.9 & 1.0 & -2.7 \\
\hline D937_69 & 0.282559 & 0.000036 & 0.00123 & 0.000062 & 0.03870 & 0.0021 & 244.4 & 0.282553 & -8.0 & 1.3 & -2.8 \\
\hline D937_70 & 0.282570 & 0.000025 & 0.00068 & 0.000008 & 0.01923 & 0.00041 & 264.4 & 0.282567 & -7.6 & 0.9 & -1.8 \\
\hline D937_71 & 0.282469 & 0.000024 & 0.00069 & 0.00018 & 0.02040 & 0.0051 & 264.8 & 0.282466 & -11.2 & 0.9 & -5.4 \\
\hline D937_72 & 0.282569 & 0.000026 & 0.00133 & 0.000025 & 0.03969 & 0.00094 & 311.9 & 0.282561 & -7.6 & 0.9 & -1.0 \\
\hline D937_73 & 0.282270 & 0.000036 & 0.00041 & 0.000008 & 0.01276 & 0.00038 & 313.6 & 0.282268 & -18.2 & 1.3 & -11.3 \\
\hline D937_74 & 0.282374 & 0.000027 & 0.0013 & 0.000077 & 0.04330 & 0.0028 & 430.4 & 0.282364 & -14.5 & 1.0 & -5.3 \\
\hline D937_75 & 0.282276 & 0.000025 & 0.00085 & 0.000014 & 0.02638 & 0.00036 & 449.1 & 0.282269 & -18.0 & 0.9 & -8.3 \\
\hline D937_76 & 0.282345 & 0.000029 & 0.00014 & 0.000002 & 0.00512 & 0.00007 & 525.0 & 0.282344 & -15.6 & 1.0 & -3.9 \\
\hline D937_77 & 0.282253 & 0.000031 & 0.00169 & 0.00025 & 0.05750 & 0.0085 & 777.5 & 0.282228 & -18.8 & 1.1 & -2.3 \\
\hline D937_78 & 0.281925 & 0.000034 & 0.00092 & 0.000031 & 0.02792 & 0.00096 & 1000.0 & 0.281908 & -30.4 & 1.2 & -8.7 \\
\hline D937_79 & 0.281901 & 0.000033 & 0.00042 & 0.000037 & 0.01097 & 0.00083 & 1044.2 & 0.281893 & -31.3 & 1.2 & -8.2 \\
\hline D937_80 & 0.281925 & 0.000028 & 0.00064 & 0.000023 & 0.01904 & 0.00071 & 1137.7 & 0.281911 & -30.4 & 1.0 & -5.4 \\
\hline D937_81 & 0.282090 & 0.000031 & 0.00038 & 0.000009 & 0.01168 & 0.00025 & 1141.1 & 0.282082 & -24.6 & 1.1 & 0.7 \\
\hline D937_82 & 0.282130 & 0.000029 & 0.00041 & 0.000007 & 0.01342 & 0.00018 & 1200.0 & 0.282121 & -23.2 & 1.0 & 3.4 \\
\hline D937_83 & 0.282051 & 0.000027 & 0.00053 & 0.000033 & 0.01740 & 0.0013 & 1200.3 & 0.282039 & -26.0 & 1.0 & 0.5 \\
\hline D937_84 & 0.282105 & 0.000024 & 0.00052 & 0.000005 & 0.01638 & 0.00013 & 1222.6 & 0.282093 & -24.0 & 0.9 & 3.0 \\
\hline D937_85 & 0.281996 & 0.000059 & 0.00069 & 0.000045 & 0.02170 & 0.0016 & 1600.0 & 0.281975 & -27.9 & 2.1 & 7.4 \\
\hline D937_86 & 0.281619 & 0.000027 & 0.00096 & 0.000062 & 0.02930 & 0.0024 & 1701.8 & 0.281588 & -41.2 & 1.0 & -4.0 \\
\hline
\end{tabular}


Table 5.1. SHRIMP U-Pb zircon data of a tonalite from the Santa Marta batholith.

\begin{tabular}{|c|c|c|c|c|c|c|c|c|c|c|c|c|c|}
\hline Spot & $\begin{array}{r}\% \\
{ }^{206} \mathrm{~Pb}_{\mathrm{c}} \\
\end{array}$ & $\begin{array}{r}\text { ppm } \\
\mathbf{U} \\
\end{array}$ & $\begin{array}{r}\text { ppm } \\
\text { Th } \\
\end{array}$ & $\begin{array}{l}{ }^{232} \mathrm{Th} \\
{ }^{238} \mathrm{U} \\
\end{array}$ & $\begin{array}{r}\mathbf{p p m} \\
{ }^{206} \mathrm{~Pb}^{*}\end{array}$ & $\begin{array}{c}(1) \\
{ }^{206} \mathrm{~Pb} \\
{ }^{238} \mathrm{U} \\
\text { Age } \\
\end{array}$ & $\begin{array}{c}(2) \\
{ }^{206} \mathbf{P b} \\
\rho^{238} \mathrm{U} \\
\text { Age } \\
\end{array}$ & $\begin{array}{c}(3) \\
{ }^{206} \mathrm{~Pb} \\
\rho^{238} \mathrm{U} \\
\text { Age }\end{array}$ & $\begin{array}{c}(1) \\
{ }^{207} \mathrm{~Pb} \\
{ }^{206} \mathrm{~Pb} \\
\text { Age } \\
\end{array}$ & $\begin{array}{c}{ }_{(1)}^{(1)} \\
{ }^{208} \mathrm{~Pb} \\
{ }^{232} \mathrm{Th} \\
\text { Age } \\
\end{array}$ & $\begin{array}{r}\% \\
\text { Dis- } \\
\text { cor- } \\
\text { dant }\end{array}$ & $\begin{array}{r}\text { Total } \\
{ }_{238} \mathrm{U} \\
\rho^{206} \mathrm{~Pb} \\
\end{array}$ & $\pm \%$ \\
\hline SM54-1.1 & 6.11 & 189 & 71 & 0.39 & 1.47 & $54.2 \pm 1.8$ & $53.5 \pm 1.0$ & $54.5 \pm 1.2$ & $485 \pm 880$ & $50 \pm 26$ & 89 & 110.7 & 1.8 \\
\hline SM54-2.1 & 11.38 & 113 & 50 & 0.46 & 0.930 & $55.4 \pm 3.7$ & $53.9 \pm 1.6$ & $54.4 \pm 2.0$ & $860 \pm 1500$ & $69 \pm 50$ & 94 & 104.7 & 2.5 \\
\hline SM54-3.1 & 10.40 & 126 & 57 & 0.47 & 1.04 & $55.3 \pm 2.8$ & $53.0 \pm 1.3$ & $55.1 \pm 1.7$ & $1,177 \pm 910$ & $57 \quad \pm 37$ & 95 & 104.3 & 2.1 \\
\hline SM54-4.1 & 8.58 & 177 & 67 & 0.39 & 1.39 & $55.4 \pm 1.9$ & $53.3 \pm 1.2$ & $53.6 \pm 1.4$ & $1,122 \pm 630$ & $83 \pm 28$ & 95 & 109.4 & 1.8 \\
\hline SM54-5.1 & 13.96 & 123 & 53 & 0.45 & 1.06 & $57.7 \pm 3.0$ & $55.6 \pm 1.3$ & $55.5 \pm 2.0$ & $1,114 \pm 980$ & $88 \quad \pm 42$ & 95 & 99.6 & 2.1 \\
\hline SM54-6.1 & 13.97 & 105 & 50 & 0.49 & 0.843 & $55.4 \quad \pm 2.9$ & $53.4 \pm 1.5$ & $51.7 \pm 1.9$ & $1,090 \pm 1000$ & $100 \pm 36$ & 95 & 106.9 & 2.3 \\
\hline SM54-7.1 & 11.78 & 125 & 56 & 0.46 & 1.02 & $58.7 \pm 2.0$ & $54.2 \pm 1.5$ & $53.5 \pm 1.7$ & $1,759 \pm 390$ & $127 \pm 23$ & 97 & 105.9 & 2.1 \\
\hline SM54-8.1 & 8.92 & 142 & 66 & 0.48 & 1.15 & $58.3 \pm 1.6$ & $55.2 \pm 1.4$ & $55.4 \pm 1.8$ & $1,418 \pm 380$ & $95 \pm 18$ & 96 & 105.5 & 2.0 \\
\hline SM54-8.2 & 8.87 & 191 & 104 & 0.56 & 1.57 & $56.9 \pm 2.0$ & $55.3 \pm 1.5$ & $55.9 \pm 1.7$ & $896 \pm 840$ & $67 \pm 21$ & 94 & 104.6 & 1.8 \\
\hline SM54-9.1 & 13.42 & 125 & 58 & 0.48 & 1.15 & $62.0 \pm 3.2$ & $58.7 \pm 2.0$ & $59.9 \pm 2.3$ & $1,412 \pm 870$ & $88 \pm 42$ & 96 & 92.8 & 2.0 \\
\hline SM54-10.1 & 14.93 & 114 & 51 & 0.46 & 0.971 & $54.9 \pm 3.8$ & $55.8 \pm 2.2$ & $54.2 \pm 2.0$ & & $65 \quad \pm 52$ & & 100.8 & 2.2 \\
\hline SM54-11.1 & 7.88 & 177 & 85 & 0.50 & 1.41 & $54.9 \pm 1.8$ & $54.9 \pm 1.1$ & $54.9 \pm 1.4$ & $-20 \pm 1200$ & $54 \pm 20$ & 442 & 107.7 & 1.8 \\
\hline SM54-12.1 & 11.36 & 135 & 51 & 0.39 & 1.12 & $53.5 \pm 3.9$ & $53.0 \pm 2.6$ & $54.7 \quad \pm 3.3$ & $420 \pm 1800$ & & 87 & 104.1 & 4.8 \\
\hline SM54-13.1 & 11.02 & 108 & 43 & 0.41 & 0.838 & $54.9 \pm 1.9$ & $52.7 \pm 1.4$ & $51.7 \pm 1.8$ & $1,197 \pm 540$ & $102 \pm 25$ & 95 & 110.4 & 2.2 \\
\hline SM54-14.1 & 11.47 & 96 & 52 & 0.56 & 0.834 & $61.6 \pm 1.5$ & $56.5 \pm 1.4$ & $57.2 \pm 2.0$ & $1,861 \pm 170$ & $109 \pm 11$ & 97 & 99.3 & 2.3 \\
\hline SM54-14.2 & 13.56 & 185 & 74 & 0.41 & 1.50 & $57.5 \pm 1.7$ & $53.5 \pm 1.0$ & $52.4 \pm 1.8$ & $1,678 \pm 330$ & $134 \pm 25$ & 97 & 106.0 & 1.8 \\
\hline SM54-15.1 & 13.70 & 128 & 52 & 0.42 & 1.07 & $53.7 \pm 3.1$ & $53.6 \pm 1.8$ & $54.1 \pm 2.1$ & $100 \pm 2300$ & $47 \quad \pm 47$ & 48 & 102.3 & 2.1 \\
\hline SM54-16.1 & 9.84 & 142 & 59 & 0.43 & 1.14 & $54.8 \pm 2.5$ & $52.6 \pm 1.6$ & $54.0 \pm 1.5$ & $1,199 \pm 880$ & $67 \pm 35$ & 95 & 107.3 & 2.0 \\
\hline SM54-16.2 & 10.33 & 133 & 75 & 0.58 & 1.11 & $57.1 \quad \pm 2.4$ & $55.0 \pm 1.3$ & $55.5 \pm 2.2$ & $1,099 \pm 780$ & $74 \pm 26$ & 95 & 103.8 & 2.0 \\
\hline
\end{tabular}


Table 5.1. Continuation.

\begin{tabular}{|c|c|c|c|c|c|c|c|c|c|c|c|c|c|c|c|c|c|c|c|}
\hline $\begin{array}{c}\text { Total } \\
{ }_{207} \mathrm{~Pb} \\
\rho^{206} \mathrm{~Pb} \\
\end{array}$ & $\pm \%$ & $\begin{array}{r}(1) \\
{ }^{238} \mathrm{U} / \\
{ }^{206} \mathrm{~Pb}^{*} \\
\end{array}$ & $\pm \%$ & $\begin{array}{r}(1) \\
{ }_{207} \mathrm{~Pb}^{*} \\
{ }^{206} \mathrm{~Pb}^{*} \\
\end{array}$ & $\pm \%$ & $\begin{array}{r}(1) \\
{ }^{207} \mathbf{P b}^{*} \\
\rho^{235} \mathrm{U} \\
\end{array}$ & $\pm \%$ & $\begin{array}{c}(1) \\
{ }^{206} \mathbf{P b}^{*} \\
\rho^{238} \mathbf{U} \\
\end{array}$ & $\pm \%$ & $\begin{array}{r}\text { err } \\
\text { corr }\end{array}$ & $\begin{array}{r}(3) \\
{ }^{238} \mathrm{U} / \\
{ }^{206} \mathrm{~Pb}^{*} \\
\end{array}$ & $\pm \%$ & $\begin{array}{r}(3) \\
{ }^{207} \mathrm{~Pb}^{*} \\
{ }^{206} \mathrm{~Pb}^{*} \\
\end{array}$ & $\pm \%$ & $\begin{array}{r}(3) \\
{ }^{207} \mathbf{P b}^{*} \\
\rho^{235} \mathrm{U} \\
\end{array}$ & $\pm \%$ & $\begin{array}{r}(3) \\
{ }^{206} \mathbf{P b}^{*} \\
/^{238} \mathrm{U} \\
\end{array}$ & $\pm \%$ & $\begin{array}{c}\text { err } \\
\text { corr }\end{array}$ \\
\hline 0.1080 & 4.9 & 118.4 & 3.3 & 0.057 & 40 & 0.066 & 40 & 0.00844 & 3.3 & .083 & 117.9 & 1.8 & 0.0588 & 9.6 & 0.0688 & 9.8 & 0.00848 & 1.8 & .182 \\
\hline 0.143 & 7.6 & 115.9 & 6.7 & 0.068 & 72 & 0.081 & 73 & 0.00863 & 6.7 & .091 & 118.1 & 2.5 & 0.050 & 24 & 0.059 & 25 & 0.00847 & 2.5 & .100 \\
\hline 0.1568 & 5.0 & 116.2 & 5.1 & 0.079 & 46 & 0.094 & 46 & 0.00861 & 5.1 & .110 & 116.4 & 2.1 & 0.0747 & 12 & 0.088 & 12 & 0.00859 & 2.1 & .174 \\
\hline 0.1194 & 6.9 & 115.9 & 3.5 & 0.077 & 31 & 0.092 & 32 & 0.00863 & 3.5 & .110 & 119.7 & 1.8 & 0.0495 & 18 & 0.057 & 19 & 0.00835 & 1.8 & .099 \\
\hline 0.1564 & 4.9 & 111.2 & 5.2 & 0.077 & 49 & 0.095 & 49 & 0.00899 & 5.2 & .106 & 115.7 & 2.1 & 0.0416 & 22 & 0.050 & 22 & 0.00864 & 2.1 & .096 \\
\hline 0.135 & 8.8 & 116.0 & 5.3 & 0.076 & 51 & 0.090 & 51 & 0.00862 & 5.3 & .103 & 124.3 & 2.3 & 0.017 & 83 & 0.019 & 83 & 0.00805 & 2.3 & .028 \\
\hline 0.131 & 9.2 & 109.4 & 3.3 & 0.108 & 21 & 0.136 & 21 & 0.00914 & 3.3 & .157 & 120.0 & 2.1 & 0.033 & 42 & 0.038 & 42 & 0.00833 & 2.1 & .051 \\
\hline 0.120 & 8.7 & 110.0 & 2.8 & 0.090 & 20 & 0.112 & 20 & 0.00909 & 2.8 & .137 & 115.8 & 2.0 & 0.048 & 24 & 0.057 & 24 & 0.00864 & 2.0 & .083 \\
\hline 0.125 & 12 & 112.9 & 3.5 & 0.069 & 41 & 0.084 & 41 & 0.00886 & 3.5 & .085 & 114.8 & 1.8 & 0.054 & 30 & 0.064 & 30 & 0.00871 & 1.8 & .058 \\
\hline 0.167 & 11 & 103.5 & 5.2 & 0.089 & 46 & 0.119 & 46 & 0.00966 & 5.2 & .113 & 107.1 & 2.0 & 0.059 & 35 & 0.076 & 35 & 0.00933 & 2.0 & .059 \\
\hline 0.145 & 15 & 116.8 & 7.0 & & & & & 0.00856 & 7.0 & & 118.5 & 2.2 & & & & & 0.00844 & 2.2 & \\
\hline 0.1092 & 4.8 & 117.0 & 3.2 & 0.046 & 48 & 0.054 & 48 & 0.00854 & 3.2 & .067 & 116.9 & 1.8 & 0.0446 & 13 & 0.0526 & 13 & 0.00856 & 1.8 & .138 \\
\hline 0.1589 & 4.8 & 119.9 & 7.3 & 0.055 & 79 & 0.063 & 79 & 0.00834 & 7.3 & .091 & 117.4 & 4.8 & 0.0685 & 13 & 0.080 & 14 & 0.00852 & 4.8 & .356 \\
\hline 0.1218 & 7.6 & 116.8 & 3.4 & 0.080 & 27 & 0.094 & 27 & 0.00856 & 3.4 & .124 & 124.1 & 2.2 & 0.030 & 35 & 0.033 & 35 & 0.00806 & 2.2 & .064 \\
\hline 0.1472 & 5.5 & 104.1 & 2.4 & 0.114 & 9.2 & 0.151 & 9.5 & 0.00961 & 2.4 & .256 & 112.2 & 2.3 & 0.0543 & 17 & 0.067 & 17 & 0.00892 & 2.3 & .134 \\
\hline 0.1396 & 4.2 & 111.5 & 2.9 & 0.103 & 18 & 0.127 & 18 & 0.00897 & 2.9 & .162 & 122.6 & 1.8 & 0.0259 & 27 & 0.0292 & 27 & 0.00816 & 1.8 & .066 \\
\hline 0.162 & 11 & 119.5 & 5.8 & 0.048 & 99 & 0.055 & 99 & 0.00837 & 5.8 & .058 & 118.6 & 2.1 & 0.051 & 41 & 0.059 & 41 & 0.00843 & 2.1 & .051 \\
\hline 0.144 & 11 & 117.1 & 4.6 & 0.080 & 45 & 0.094 & 45 & 0.00854 & 4.6 & .102 & 119.0 & 2.0 & 0.065 & 27 & 0.075 & 27 & 0.00841 & 2.0 & .073 \\
\hline 0.1344 & 5.7 & 112.3 & 4.2 & 0.076 & 39 & 0.093 & 39 & 0.00890 & 4.2 & .108 & 115.7 & 2.0 & 0.0504 & 17 & 0.060 & 17 & 0.00864 & 2.0 & .117 \\
\hline
\end{tabular}


Table 5.2. AMS parameters of the Santa Marta batholith. N, number of specimens; K, mean-site susceptibility (10 $\left.{ }^{-3} \mathrm{SI}\right)$; $\mathrm{P}$, anisotropy degree; $\mathrm{T}$, shape parameter; $\mathrm{K}_{1}, \mathrm{~K}_{2}$ and $\mathrm{K}_{3}$ are the orientation (in azimuth and dip) of the AMS principal directions. $\alpha_{1,2,3}$ are the angular dispersion (measured in degree) of the confidence ellipses around the principal directions.

\begin{tabular}{|c|c|c|c|c|c|c|c|c|c|c|c|c|c|c|c|}
\hline \multirow[b]{2}{*}{ Site } & \multirow[b]{2}{*}{ UTM } & & \multirow[b]{2}{*}{$\mathrm{N}$} & \multirow[b]{2}{*}{$\mathrm{K}(\mathrm{mSI})$} & \multirow[b]{2}{*}{$\mathrm{P}$} & \multirow[b]{2}{*}{$\mathrm{T}$} & \multicolumn{3}{|l|}{$\mathrm{K}_{1}$} & \multicolumn{3}{|l|}{$\mathrm{K}_{2}$} & \multicolumn{3}{|l|}{$\mathrm{K}_{3}$} \\
\hline & & & & & & & dec & inc & $\alpha_{1}$ & dec & inc & $\alpha_{2}$ & dec & inc & $\alpha_{3}$ \\
\hline SM1 & 595420 & 1231860 & 11 & 0.08 & 1.07 & 0.29 & 33 & 4 & 7.1 & 187 & 86 & 7.6 & 303 & 2 & 8.1 \\
\hline SM2 & 584904 & 1236044 & 11 & 0.04 & 1.04 & 0.10 & 95 & 77 & 12.6 & 228 & 9 & 28.7 & 28 & 3 & 2.7 \\
\hline SM3 & 610742 & 1247622 & 10 & 0.06 & 1.11 & 0.17 & 275 & 80 & 6.7 & 37 & 5 & 8.9 & 128 & 8 & 9.1 \\
\hline SM4 & 614284 & 1247143 & 9 & 0.05 & 1.12 & 0.49 & 323 & 62 & 5.6 & 190 & 19 & 14.6 & 93 & 19 & 14.1 \\
\hline SM5 & 597291 & 1239609 & 11 & 10.40 & 1.32 & 0.03 & 209 & 28 & 10.7 & 96 & 37 & 12.3 & 325 & 40 & 10.9 \\
\hline SM6 & 598354 & 1239671 & 10 & 6.95 & 1.31 & -0.03 & 341 & 39 & 13.1 & 178 & 50 & 18.9 & 78 & 9 & 17.5 \\
\hline SM7 & 599879 & 1240850 & 9 & 5.84 & 1.23 & -0.33 & 63 & 19 & 18.6 & 245 & 71 & 26.5 & 153 & 1 & 25.0 \\
\hline SM8 & 601448 & 1242326 & 12 & 5.95 & 1.25 & 0.35 & 92 & 47 & 15.8 & 293 & 41 & 15.9 & 194 & 10 & 12.3 \\
\hline SM9 & 601942 & 1243181 & 10 & 13.10 & 1.15 & 0.10 & 236 & 69 & 26.5 & 340 & 6 & 28.4 & 72 & 20 & 16.0 \\
\hline SM10 & 597150 & 1241586 & 9 & 7.79 & 1.24 & 0.48 & 293 & 43 & 34.6 & 89 & 44 & 34.6 & 191 & 12 & 8.1 \\
\hline SM11 & 606092 & 1247514 & 9 & 8.69 & 1.28 & 0.52 & 33 & 84 & 22.5 & 174 & 5 & 22.7 & 264 & 4 & 7.6 \\
\hline SM12 & 605804 & 1249331 & 9 & 0.22 & 1.04 & 0.37 & 46 & 38 & 13.8 & 304 & 17 & 20.4 & 194 & 47 & 20.3 \\
\hline SM13 & 605545 & 1248396 & 9 & 0.48 & 1.09 & 0.17 & 188 & 18 & 16.6 & 285 & 21 & 17.6 & 61 & 61 & 18.9 \\
\hline SM14 & 604940 & 1246576 & 10 & 8.19 & 1.20 & 0.40 & 175 & 3 & 37.5 & 78 & 68 & 37.5 & 266 & 21 & 11.1 \\
\hline SM15 & 601354 & 1245856 & 10 & 11.80 & 1.13 & 0.20 & 25 & 49 & 14.6 & 219 & 40 & 13.2 & 123 & 7 & 11.2 \\
\hline SM16 & 602768 & 1242329 & 17 & 15.50 & 1.22 & -0.19 & 240 & 4 & 10.5 & 350 & 78 & 13.1 & 149 & 11 & 11.9 \\
\hline SM17 & 604055 & 1242246 & 9 & 15.00 & 1.18 & 0.54 & 154 & 41 & 8.9 & 310 & 46 & 8.9 & 53 & 12 & 10.3 \\
\hline SM18 & 606590 & 1241100 & 12 & 11.50 & 1.26 & 0.48 & 320 & 63 & 30.0 & 109 & 23 & 29.9 & 205 & 12 & 12.2 \\
\hline SM19 & 606699 & 1241801 & 8 & 7.74 & 1.27 & 0.34 & 211 & 28 & 25.6 & 18 & 62 & 26.1 & 118 & 5 & 16.4 \\
\hline SM20 & 607207 & 1242959 & 12 & 7.48 & 1.43 & 0.54 & 163 & 0 & 21.1 & 253 & 57 & 21.2 & 72 & 33 & 6.0 \\
\hline SM21 & 592612 & 1240447 & 13 & 0.70 & 1.06 & 0.00 & 57 & 11 & 24.4 & 324 & 17 & 29.6 & 177 & 69 & 28.5 \\
\hline SM22 & 593735 & 1241763 & 9 & 0.80 & 1.03 & 0.00 & 192 & 30 & 18.4 & 98 & 6 & 20.8 & 358 & 60 & 13.2 \\
\hline SM23 & 594427 & 1239925 & 10 & 5.06 & 1.29 & 0.60 & 224 & 34 & 21.3 & 102 & 38 & 21.2 & 341 & 33 & 5.7 \\
\hline SM24 & 584366 & 1235366 & 10 & 0.16 & 1.07 & 0.65 & 310 & 40 & 14.7 & 51 & 12 & 14.2 & 154 & 48 & 7.8 \\
\hline SM25 & 615951 & 1250722 & 6 & 0.02 & 1.08 & 0.04 & 328 & 16 & 20.0 & 92 & 63 & 20.2 & 231 & 21 & 5.6 \\
\hline SM26 & 606673 & 1242317 & 9 & 0.09 & 1.07 & -0.06 & 131 & 29 & 10.3 & 28 & 22 & 22.4 & 266 & 52 & 23.0 \\
\hline SM27 & 596357 & 1242193 & 10 & 8.58 & 1.20 & 0.52 & 182 & 63 & 12.8 & 72 & 10 & 15.3 & 338 & 25 & 10.8 \\
\hline SM28 & 599758 & 1242489 & 9 & 6.04 & 1.38 & 0.42 & 200 & 60 & 19.7 & 44 & 27 & 19.9 & 309 & 10 & 5.8 \\
\hline SM29 & 624506 & 1245924 & 11 & 6.27 & 1.10 & 0.07 & 245 & 13 & 27.7 & 149 & 22 & 27.6 & 2 & 64 & 12.4 \\
\hline SM30 & 622239 & 1246458 & 11 & 4.06 & 1.28 & 0.03 & 90 & 29 & 9.8 & 354 & 10 & 15.1 & 247 & 59 & 14.2 \\
\hline SM31 & 620463 & 1244937 & 13 & 4.57 & 1.29 & 0.12 & 246 & 48 & 15.2 & 345 & 16 & 16.3 & 97 & 38 & 9.5 \\
\hline SM32 & 620447 & 1247919 & 12 & 4.67 & 1.21 & 0.25 & 241 & 14 & 19.0 & 147 & 16 & 13.3 & 10 & 69 & 21.3 \\
\hline SM33 & 609225 & 1248711 & 15 & 8.58 & 1.41 & 0.26 & 24 & 2 & 24.2 & 118 & 60 & 27.8 & 293 & 30 & 17.6 \\
\hline
\end{tabular}




\begin{tabular}{|c|c|c|c|c|c|c|c|c|c|c|c|c|c|c|c|}
\hline SM34 & 609682 & 249957 & 9 & 0.46 & 1.07 & 0.11 & 188 & 21 & 27.3 & 96 & t & 32.5 & 348 & 68 & 32.4 \\
\hline SM35 & 610558 & 1251223 & 12 & 6.31 & 1.30 & 0.18 & 179 & . & 12.7 & 88 & 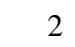 & 12.8 & 334 & 85 & 10.1 \\
\hline SM36 & 611511 & 252129 & 10 & 0.23 & 1.07 & 0.58 & 69 & 21 & 11.6 & 162 & 8 & 11.6 & 271 & 57 & 5.6 \\
\hline SM37 & 612435 & 252738 & 11 & 7.55 & .51 & 0.52 & 54 & 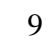 & 11.5 & 158 & 57 & 11.4 & 318 & 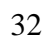 & 8.9 \\
\hline SM38 & 613221 & 252644 & 17 & 1.63 & .24 & 0.43 & 232 & 18 & 13.3 & 122 & 47 & 13.4 & 336 & 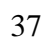 & 5.0 \\
\hline SM39 & 614501 & 251296 & 13 & 4.18 & 1.16 & -0.06 & 203 & 61 & 12.0 & 316 & 12 & 11.3 & 52 & 26 & 11.6 \\
\hline SM40 & 617350 & 250217 & 8 & 2.79 & 1.20 & 0.36 & 11 & 8 & 25.7 & 279 & 13 & 25.1 & 132 & 75 & 15.0 \\
\hline SM41 & 616476 & 1250712 & 11 & 10.80 & 1.45 & 0.02 & 179 & 35 & 8.2 & 295 & 31 & 10.3 & 54 & 39 & 9.2 \\
\hline SM42 & 618562 & 247768 & 13 & 6.30 & 1.18 & 0.00 & 89 & 44 & 18.7 & 267 & 46 & 18.7 & 358 & 1 & 9.7 \\
\hline SM43 & 613524 & 246921 & 10 & 13.30 & 1.38 & 0.29 & 208 & 12 & 21.7 & 303 & 25 & 21.5 & 95 & 62 & 8.7 \\
\hline SM44 & 611302 & 1247 & 19 & 7.67 & 1.27 & -0.01 & 192 & 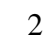 & 9.8 & 92 & 81 & 12.4 & 282 & 8 & 10.4 \\
\hline SM45 & 603274 & 1245857 & 8 & 11.80 & 1.17 & 0.23 & 19 & 44 & 34.9 & 199 & 46 & 35.6 & 289 & 1 & 12.5 \\
\hline SM46 & 585930 & 224522 & 12 & 0.05 & 1.12 & 0.22 & 151 & 54 & 15.9 & 46 & 11 & 16.6 & 308 & 34 & 11.1 \\
\hline M47 & 588299 & 5 & 14 & 0 & 04 & 0.27 & 118 & 1 & 21.6 & 209 & 20 & 1.5 & 27 & 69 & 13.9 \\
\hline M48 & 590518 & 1234530 & 9 & 0.28 & 1.05 & -0.26 & 141 & 36 & 21.6 & 21 & 35 & 33.5 & 261 & 35 & 32.9 \\
\hline M49 & 589950 & 235418 & 9 & 0.43 & 1.04 & -0.07 & 72 & 23 & 13.3 & 183 & 39 & 22.7 & 320 & 42 & 21.9 \\
\hline M50 & 591892 & 0 & 13 & 1 & 3 & 0.32 & 17 & 37 & 14.0 & 123 & 20 & 1.2 & 236 & 46 & 6.4 \\
\hline SM51 & 592797 & 1236730 & 8 & 11.50 & 1.20 & 0.28 & 208 & 45 & 26.2 & 42 & 44 & 26.4 & 306 & 7 & 10.0 \\
\hline M52 & 593424 & 235046 & 10 & 13.80 & 1.21 & 0.25 & 112 & 55 & 15.7 & 251 & 28 & 26.8 & 352 & 19 & 26.8 \\
\hline M53 & 594688 & 00 & 7 & 1240 & 1.18 & 0. & 89 & 31 & 16.7 & 193 & 21 & 18.6 & 311 & 51 & 17.2 \\
\hline SM54 & 595477 & 1233814 & 15 & 15.70 & 1.23 & 0.18 & 87 & 11 & 27.4 & 348 & 38 & 25.4 & 190 & 50 & 16.1 \\
\hline SM55 & 596298 & 231703 & 8 & 1.01 & 1.14 & -0.04 & 234 & 68 & 15.5 & 21 & 18.9 & 27.6 & 115 & 11 & 26.7 \\
\hline M56 & 597866 & 1231161 & 12 & 16 & 1.07 & 0.37 & 165 & 46 & 11.8 & 272 & 16 & 10.3 & 16 & 39 & 12.1 \\
\hline M57 & 598159 & 1230251 & 10 & 0.25 & 1.11 & 0.61 & 13 & 42 & 9.8 & 126 & 24 & 7.2 & 237 & 39 & 9.9 \\
\hline SM58 & 596385 & 230241 & 10 & 0.40 & 1.07 & 0.02 & 341 & 14 & 67.2 & 175 & 76 & 67.1 & 72 & 3 & 19.5 \\
\hline M59 & 596249 & 1229377 & 12 & 0.69 & 1.06 & -0.35 & 214 & 7 & 10.9 & 305 & 2 & 21.1 & 53 & 82 & 19.5 \\
\hline SM60 & 595856 & 1228812 & 11 & 0.50 & 1.06 & -0.28 & 5 & 59 & 13.5 & 100 & 3 & 18.6 & 192 & 31 & 18.8 \\
\hline SM61 & 595582 & 1228075 & 10 & 0.72 & 1.07 & -0.18 & 109 & 42 & 5.3 & 353 & 25 & 8.1 & 242 & 37 & 8.0 \\
\hline M62 & 593702 & 1233100 & 12 & .30 & 1.09 & 0.72 & 174 & 12 & 32.1 & 273 & 35 & 32.0 & 67 & 52 & 4.8 \\
\hline SM63 & 584898 & 1228839 & 9 & 0.22 & 1.04 & 0.42 & 106 & 63 & 23.3 & 291 & 27 & 23.3 & 200 & 2 & 9.6 \\
\hline SM64 & 586868 & 227619 & 18 & & 1.06 & 0.47 & 42 & 31 & 22.9 & 134 & 4 & 22.8 & 230 & 58 & 6.7 \\
\hline SM65 & 588238 & 1227768 & 15 & 0.93 & 1.09 & -0.13 & 124 & 15 & 12.2 & 32 & 6 & 14.9 & 289 & 74 & 15.0 \\
\hline SM66 & 586236 & 1227343 & 14 & 0.47 & 1.08 & -0.11 & 69 & 22 & 7.3 & 331 & 20 & 8.7 & 202 & 59 & 8.8 \\
\hline M67 & 588538 & 1221387 & 10 & 234 & 1.14 & -0.09 & 244 & 29 & 12.8 & 339 & 9 & 27.0 & 85 & 60 & 27.0 \\
\hline SM68 & 587275 & 1218411 & 15 & 1.55 & 1.09 & 0.31 & 272 & 18 & 53.9 & 149 & 60 & 54.0 & 10 & 24 & 16.7 \\
\hline SM69 & 584570 & 1234156 & 10 & 0.18 & 1.06 & 0.16 & 50 & 3 & 6.5 & 142 & 40 & 13.4 & 316 & 49 & 14.1 \\
\hline
\end{tabular}

